\title{
Orchestrating the Public: \\ A Contribution to the Critique of Modern Police Power
}

by

Gülden Özcan

A thesis submitted to the Faculty of Graduate and Postdoctoral Affairs in partial fulfillment of the requirements for the degree of

Doctor of Philosophy

in

Sociology

Carleton University

Ottawa, ON

(C) 2017

Gülden Özcan 


\begin{abstract}
This study examines the relationship between the projects of 'police' and the 'public' with a focus on seventeenth- and eighteenth-century police science in Europe and late eighteenth- and early nineteenth-century police in London, England. The study primarily investigates how the ideals of police and the public constitute the raison d'être of the modern state; how the ideal of police and the public evolved into the institutions of the police and the public sphere; and how the main principles involved in these ideals orchestrated the kind of public specific to modern politics.

The central argument is that the construction of the public and the public sphere as governable targets has been crucial for fabricating and sustaining the modern social order, and that this construction was made convenient under modern police power. Modern police power can therefore best be understood through an examination of the kind of publics it has generated and governed. Accordingly, this study develops a new approach to the concept of the public from the perspective of the social while situating police in the broader political context of modern state formation. In so doing, the study adopts Marx's theory to locate the projects of police and the public in capitalist class structures while Foucault's conceptual toolkit is used to analyse the construction, implementation, and power effects of these projects through discursive and non-discursive practices.

The broad project of police is examined in relation to capital accumulation, state formation, and political economy. The abstraction of the public sphere is given a materialist reading by (re-)conceptualizing three major public spheres: the bourgeois public sphere as the ideal target, the proletarian public sphere as its dialectical opposite, and the market-public as its supplement.

In conclusion, this thesis shows that police power turns all kinds of potential dissenting populations, often pro-actively, into the public; that is, an addressable, responsible, accountable, and transparent subject. This in turn makes dissent predictable, reversible, and non-anonymous. More broadly, the perspective developed here can help to better comprehend how modern police power forms, deforms, and reforms the diverse publics of marginalized populations to make and orchestrate the public.
\end{abstract}

Key Words: police power, police science, bourgeois public sphere, proletarian public sphere, market-public 
Dedicated to

my first teacher and life-long mentor:

Meltem Özcan 


\section{ACKNOWLEDGEMENTS}

I am indebted to my supervisors Alan Hunt and George S. Rigakos for their encouragement and patience in the completion of this dissertation. I feel privileged to have conducted my studies under Alan's mentorship since my arrival at Carleton University. I feel fortunate to have George's continuous guidance and collaboration in my scholarly endeavors. I am grateful to my committee member Justin Paulson who has always been very generous to share his time, advice, and knowledge with me. Justin's support and inspiration made my overall experience as a $\mathrm{PhD}$ student remarkable. Many thanks to Simten Coşar for acting as an unofficial member of my committee and for her unending support since the first days of my undergraduate studies. I am thankful to my internal examiner Amy Bartholomew for her much valued contributions to the discussions during my defense that opened new paths for future collaborations. I am truly grateful to my external examiner, Mariana Valverde, for taking the time to read my dissertation and providing very detailed and helpful feedback. I look forward to our future conversation.

I would like to thank the faculty, graduate students, and administrator support staff in the Department of Sociology and Anthropology for their efforts to create a healthy workplace for all. I am particularly grateful to Xiaobei Chen, Aaron Doyle, Paula Whissell, Marlene Brancato, Janet Siltanen, Zoe Todd, Bernhard Leistle, Tonya Davidson, William Flyn, Melissa Conte, Jiyoung An, Dan Houser, and Darlene Moss for being around and making me feel welcome when I returned to the department to complete my dissertation.

This project often went in tandem with other involvements and activism, which contributed much to my intellectual development as well as the development of ideas in this thesis. I want to acknowledge the groups I took part in as a way of thanking number of friends I have collaborated with in these groups: Critical Social Research Collaborative, Negative Theatre, Socialist Project Ottawa, Red Quill Books, Alternate Routes, Anti-Security Collective, Kampfplatz, Ottawa Platform for Solidarity with Gezi, Geziniyoruz Network, Voices in Dialogue, Research Institute on Turkey, and Academics for Peace.

The completion of this dissertation was a long journey. At times, I felt lost while trying to claim a place in this new country, social class, education level, language, and culture I migrated to. Thanks to the mentorship and unending support of my dear friends Reyhan Kaya, Bülent Aslan, Tuğba Özcan, Bora Erdağı, Ersin Aslıtürk, Mete Pamir, Gülengül Nalis, and Simten Coşar, I managed to navigate my way through the completion of my degree. Thanks to Çağlar Dölek for reminding me the significance of my work and for caring to follow the lead it may offer. Thanks to Chantal and Nail Erdoğan for making the serving job at their restaurant available for me whenever I needed it throughout my studies.

I am indebted to my parents, Gülizar Öztekin and Ali İhsan Özcan, and my sister, Meltem Özcan for making sacrifices to allow me the opportunity to follow my path and for raising me with a vision of a better world. Thanks to my niece, Hazal, with whom I have yet to meet without the medium of webcams and screens. She became my main motivation!

Special thanks to my partner, Özgür Çınar without whom life would be a lot less bearable. Finally, thanks to Cazibe for keeping me company for days and nights of writing. 


\section{TABLE OF CONTENTS}

ABSTRACT

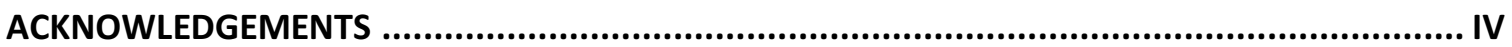

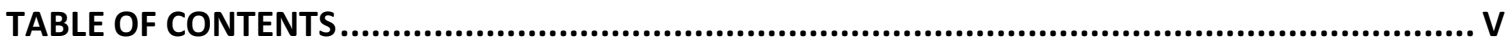

INTRODUCTION: MODERNITY VERSUS CAPITALISM? ........................................................

CHAPTER ONE: THE PUZZLING NATURE OF POLICE AND THE PUBLIC ...................................18

I. THe PuZZle: TAKIng Police AND the Public Into Account Together ................................................20

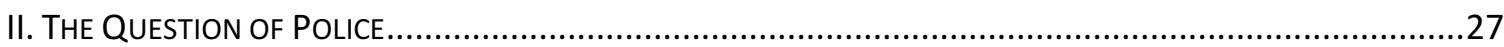

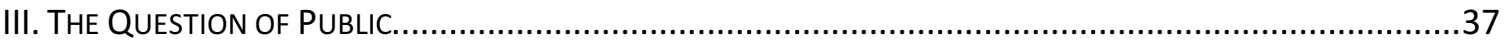

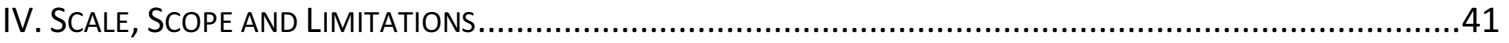

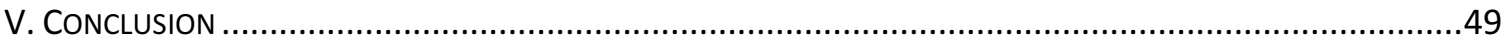

CHAPTER TWO: A SOCIAL NARRATIVE OF THE POLITICAL PUBLIC .....................................50

I. The Destiny of The Public Sphere as an Enlightenment Project ....................................................51

II. A Critique of the Bourgeois Public Sphere from the Perspective of the Social ..........................68

III. IN BETWEen the ConsPicuous ChARM AND the DISCREet DISTASTE OF THE BOURGEOISIE ......................82

IV. From labour to Action: The Whereabouts of the Proletarian Public Sphere............................85

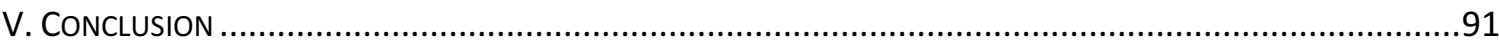

CHAPTER THREE: A POLITICAL NARRATIVE OF THE SOCIAL POLICE......................................93

I. The DeStiny Of Police AS AN EnLIGHTENMENT Project ...............................................................95

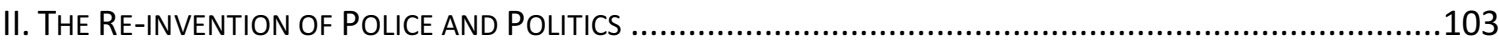

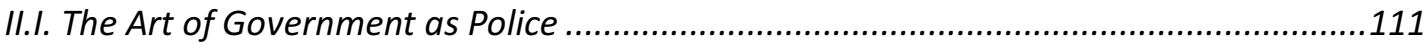

II.II. Politics as Political Economy under the Police Science ................................................119

III. The Ideal of Police SCience as Political Economy: Primitive Accumulation..............................126

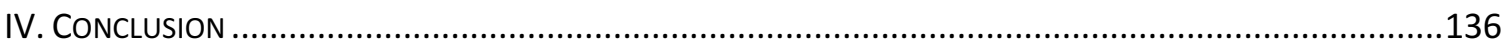




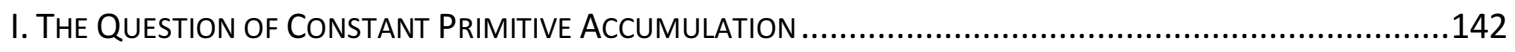

I.I. The Making of the Public-Private Divide through Enclosure .........................................144

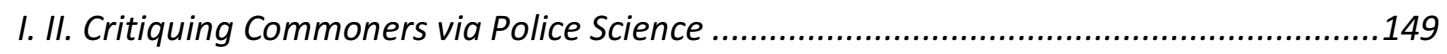

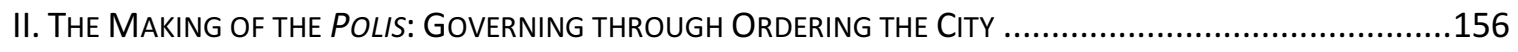

III. From the Police State to the Public Police: The Birth of the Communication Apparatus ..........165

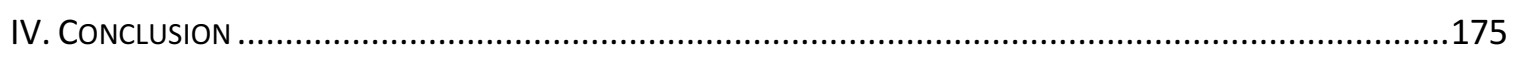

CHAPTER FIVE: (RE-)CLAIMING THE PROLETARIAN PUBLICS ......................................178

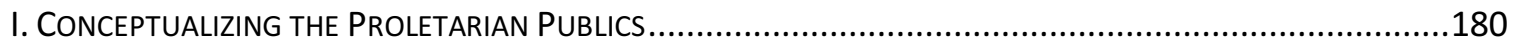

II. The Formation of the Proletarian Publics And Police Power ...................................................194

III. The Fostering Care of the Government: The River Thames Police .........................................198

IV. Questioning the Revolutionary Potential of the Proletarian Publics ...................................210

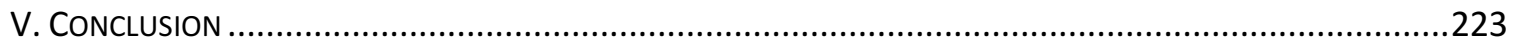

CHAPTER SIX: MARKET-PUBLICS, THE PUBLIC SIGNIFICANCE OF THE PRIVATE SPHERES ........225

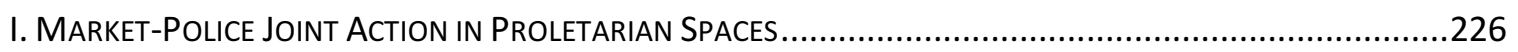

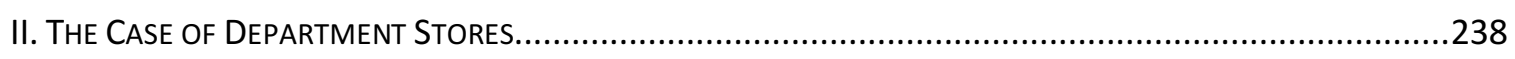

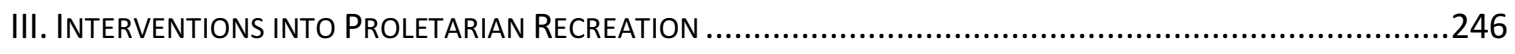

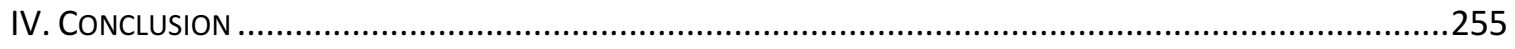

CONCLUSION: REMARKS ON THE CONSOLIDATION OF THE PUBLIC SPHERE ........................257

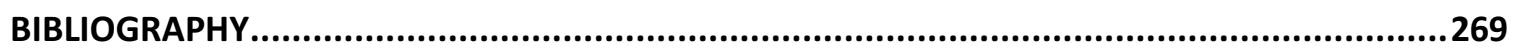




\section{INTRODUCTION}

\section{MODERNITY VERSUS CAPITALISM?}

The challenge of modernity is to live without illusions and without becoming disillusioned.

Antonio Gramsci

Throughout the history of modern Western social and political thought, inquiries regarding the nature of politics specific to our societies have always ended up attempting to solve the supposedly inherent contradiction between modernity and capitalism. Neither conservative nor radical political thinkers were able to imagine how the humanist values of the Enlightenment and the increasingly dehumanizing character of capitalism could ever be reconciled. From Carl Schmitt to Georg Lukàcs, from Leo Strauss to Theodor Adorno, from Hannah Arendt to Jürgen Habermas, to name just a few, attempts to understand the content and workings of politics in modern times have all experienced this impasse. While Schmitt's criticisms go as far as arguing that "[the liberal bourgeoisie] abolished the aristocracy of blood and family but permitted the impudent rule of the moneyed aristocracy, the most ignorant and the most ordinary form of an aristocracy," ${ }^{1}$ Arendt finds an escape by differentiating the modern age from the actual modern world, observing that "[s]cientifically, the modern age which began in the seventeenth century came to an end at

\footnotetext{
${ }^{1}$ Carl Schmitt, Political Theology: four chapters on the concept of sovereignty, Chicago: University of Chicago Press, 1985, pp. 59-60.
} 
the beginning of the twentieth century; politically, the modern world, in which we live today, was born with the first atomic explosions." ${ }^{2}$ Habermas reaches beyond the impasse by describing modernity as an "unfinished project." He regards "the colonization of the life world by the market" as a deviation from the modern ideal ${ }^{3}$ while Bruno Latour says "we have never been modern" and tries to ignore the issue entirely. ${ }^{4}$

Explanations of the contradictory character of modernity have been more effective, as in Stuart Hall's words: “'Modernity' has acquired a relentlessly uneven and contradictory character: material abundance here, producing poverty and immiseration there; greater diversity and choice-but often at the cost of commodification, fragmentation and isolation." ${ }^{5}$ That is, it is safe to argue that modernity's contradictory character simultaneously allows both the 'true' development of humanity and vulgar forms of capitalist exploitation. But what if modernity and capitalism imply the very same ideal? What if modernity as a philosophical form paves the way for capitalism to exist? What if the very ideals of modernity have prepared the conditions for, given permission to, and developed together with, the capitalist exploitation of human labour? What if no such tension between modernity and capitalism exists? In other words, what if capitalism is

\footnotetext{
${ }^{2}$ Hannah Arendt, The Human Condition, Chicago: The University of Chicago Press, 1998, p. 6.

${ }^{3}$ See Jürgen Habermas, "Modernity versus Postmodernity" in New German Critique, No. 22, Winter, 1981, pp. 3-14.

${ }^{4}$ See Bruno Latour, We Have Never Been Modern, Cambridge: Harvard University Press, 1993. In his book, Latour argues that the major pitfalls of modernity - the dualities it draws such as naturesociety, human-nonhuman, science-politics, above-below, purification-hybridization, God-King (constitution), laboratory-social contract, rationality-obscurantism, false ideology-true sciencehave never been valid in practice due to the indivisibility of these so-called dualities.

${ }^{5}$ Stuart Hall, "The Meaning of New Times" in David Morley and Kuan-Hsing Chen (Eds.), Stuart Hall: Critical Dialogues in Cultural Studies, London: Routledge, 1996, pp. 228-229.
} 
simply one of the defining structures of modernity? And finally, what if the tension that modernity carries within itself should be examined from outside of it?

The modern era, starting in the seventeenth century, marks a new mode of knowledge, government, and production in every aspect of life. The nature of these new relations can be explained in terms of a great breaking-up with the immediate means of subsistence in the broadest sense of the term: people encountered a gradual disconnection from the immediate means of intellectual subsistence alongside their detachment from the Church so that the meaning of life was no longer based on the familiar sources provided by the priest. The new source of meaning turned out to be books, the great gift of print capitalism $!^{6}$ Meanwhile, the means of material subsistence became detached from the masses through capitalism. The capitalist mode of production put the means of production and raw materials out of the immediate reach of the people so that obtaining the means of subsistence required a new relationship with the world of commodities, entailing the mediation of market relations. The means of political subsistence, in terms of attachment to a community and its governing authority, was replaced by the authority of the centralized state, with the governors removed from the immediate reach of the people. Even the perception of belonging to a community and of having a personal history was placed at a greater distance from the masses through new forms of belonging, mediated and narrated through official history. Thus, the means of (material, social, political, spiritual, intellectual, and military) subsistence were gradually removed from the people's

${ }^{6}$ See Benedict Anderson, The Imagined Communities, New York: Verso, [1982] 2006, for his historical materialist analysis of the role of print capitalism in the processes of modernization and nationalization. 
immediate resources and relocated to a distanced, centralized domain. As a result, while interdependence between people increased, the mediators (wage relations, books, voting/central state authority, laws, the bible, police forces, and so on) became the real sources of life. These mediators were designed and re-designed through modern scientific methods such that, ideally, nothing (regarding the means of a population's subsistence) was to be ignored.

This is the point at which a so-called police science of the late seventeenth and eighteenth centuries emerged. Police science justified the need for this transition from immediate relations to mediated relations—-between people and their material life, people and people, people and their souls—by proposing strategies to regulate these mediated relations in the most 'efficient' way possible. The sphere of (social, political and economic) action, which had once been regulated through immediate relations with the means of subsistence, was now re-regulated through mediators. Scholars writing on state matters during this period, who were thrilled by the modern scientific method, tried to apply the same method to society.

Theories on the state and its subjects, i.e. on police, were therefore all about an attempt to create an embodied object of inquiry with strictly demarcated borders and perfectly regulated content to allow 'police scientists' to work on it. Thus, defining the conditions, forms, and contents of the sphere in which people act in plurality became critically important. As Philip Corrigan and Derek Sayer put it, "[f]rom an early date, state activities focus coherently and cumulatively to regulate all forms of 'making public,"' referring to such public activities as printing and publishing, dramatic performance, 
singing, speaking, and/or reading aloud, preaching, graphic, and other visual depictions. ${ }^{7}$ Nevertheless, this history of state intervention in 'making public' and thus 'making the public' did not unfold without recourse to its dialectical opposite; that is, constructing the public sphere of bourgeois politics involved the emergence of market-public spheres as its supplement and proletarian public spheres as its opposite.

My central argument in this dissertation can be stated as follows: the modern projects of police and the public have combined to shape the modern idea of state formation and the kind of politics that is specific to bourgeois societies. Thus, the history of capitalism reveals a history of making a single public, thereby constructing an economically productive and politically limited social order through the broad project of police. In arguing so, I should immediately note that the broader aim of my dissertation is not to draft a police theory or a public sphere theory, but to search for socio-historical answers to problems concerning the police and the public. Both are central to contemporary discussions about security fetishism, whether situating the police as hindering public interaction or problematizing the privatization of public spaces through private security forces. My inquiry here counters such a line of discussion about the police and the public by exploring those projects of police and the public that have always worked hand in hand to create order in bourgeois societies. Thus, examining the history of police theory alongside practical police projects within the development of the public sphere-both of which lie at the very heart of modern capitalism—allows us better unravel the so-called

\footnotetext{
7 Philip Corrigan and Derek Sayer, The Great Arch: English State Formation as Cultural Revolution, Oxford: Basil Blackwell Ltd, 1985, p. 23.
} 
contradiction between modern ideals and capitalist realities. Deploying the idea of police in order to understand the public sphere is a penetrating analytic tool as the police project both regulates conduct in the public sphere while supposedly protecting private individual subjects from the strangers who constitute the public.

In this regard, I explore in my dissertation three interrelated issues in relation to the following claims. First, I claim that, commencing with the mid-seventeenth century, one can note the 'reinvention of politics' with its newly defined sphere of subjects and targets. In this process, new modes of political power and knowledge production turned police science into a crucial tool-box for modern nation-states to strategize with: first as a method to centralize governmental power then as a strategy to exercise power over each and every subject. My second claim is that the idea of police was significant for the sustainability of the capitalist relations of exploitation as the new relations of production had to be regulated, with new measures taken against a new army of labour since the birth of the modern sociopolitical order. The police science of the eighteenth century played a significant role in expanding the reach of a new mode of exploitation, i.e. capitalist exploitation. I call this the 're-creation of political economy,' expanding the scope of the economy from households to the whole nation. In that the police ideal became inescapable; not only to keep watchful eyes on the free, rebellious, culturally diverse, somewhat intellectually capable, and hence 'dangerous' classes, but also to increase their justifiable 'rationalized' utility.

My third claim is that the police project has served as a preliminary mechanism for 
homogenizing and simplifying (and thus stereotyping ${ }^{8}$ ) the cultural and moral differences amongst the working classes while maintaining the life-style distinctions between the bourgeoisie and proletariat; hence, the police has become the crucial institution in the organization of the reified social relations that fetishize notions of good order, morality, and security. The police helped foster the hegemony of the new mode of governance along with capitalist ideals while at the same time informing, training, civilizing, and organizing people. In doing so, the police targeted diverse public spheres of the working classes, meaning the places where particular working class experiences are organized. What I call the 're-formation of popular culture' was realized through the hands of police, and the physical sphere of social action was designed accordingly. We have, therefore, a triangle of a reinvented politics, recreated economy, and reformed popular culture, within which I try to understand the relationship of police power to the public sphere.

All these three claims will be tested through the example of eighteenth- and nineteenth-century England, where the Metropolitan Police appeared as the first example of the modern police force and where, in Marx's words, the working class "has gained a clear consciousness of its position as a class, and where even the rural districts know no longer any peasants, but only landlords, industrial capitalists (farmers) and hired laborers." In this sense, focusing more on the case of eighteenth- and nineteenth-century England in exploring the modern police institution helps us understand the specific relationship

\footnotetext{
${ }^{8}$ Stuart Hall makes the case how typing works in relation to stereotyping. Hall, "The Spectacle of the Other" in Stuart Hall (ed.), Representation: Cultural Representations and Signifying Practices, London: Sage Publications, 1997, see in particular pp. 257-291.

${ }^{9}$ Marx, "The Chartists" in Karl Marx and Frederick Engels, Marx and Engels on Britain, Moscow: Progress Publishers, 1962.
} 
between the police and capital. ${ }^{10}$

Against this background, in the first chapter of this thesis, I briefly situate the relationship between the conceptual history of the police and the public. In doing so, I explore the possible conclusions that can be drawn from analyzing both concepts in tandem. In the first part of the chapter, I establish the link between the public and the police by arguing that the public ideal of eighteenth-century Enlightenment thought materialized in nineteenth-century police action. In the second and third parts, I reveal the difficulties of studying the concepts of police and the public, respectively. In the fourth part, I outline the scale, scope, and limits of the overall project.

The second chapter outlines the existing literature on the public sphere and explores the possibility of reading political publics from the viewpoint of the social. In the first part, I take issue with the ways in which the public and the public sphere have been problematized in the history of social and political thought, in particular in (and with reference to) Enlightenment thought. In so doing, I draw mainly on the works of Kant, Arendt, and Habermas. In the second part, I attempt to critique Arendt's and Habermas's problematizations of the bourgeois public sphere. Here, I mainly refer to historical accounts by Richard Sennett, Michael Warner, Robert D. Storch, and Craig Calhoun. In the third part, I delineate market-public spheres by drawing on Negt and Kluge's definition of the "new public spheres of industrial production." In this part, in opposition to Habermas and others who situate the market as an obstacle to the realization of the full potential of the

${ }^{10}$ Of course, the abundance of studies available in English on policing in eighteenth- and nineteenth-century England has also had impact on this decision. 
public sphere, I reveal the public relevance of the market in the history of capitalist societies. In the fourth part, I try to develop Negt and Kluge's concept of proletarian public spheres, first by drawing on the problems they have in defining and contextualizing the term, and second by historicizing the term.

In the third chapter, I focus on the origins of the concept of police and its place in European social and political thought. I look at the texts of early police scientists, including Sir William Petty, Johann von Justi, Joseph von Sonnenfels, Sir John A. Fielding, Adam Smith, Cesare Beccaria, Wilhelm von Humboldt, Jeremy Bentham, and Patrick Colquhoun. I analyze the way they define the police ideal in terms of the condition and internal affairs of the state, and the way they situate the concern of the public in these seventeenth- and eighteenth-century texts. In the first part, drawing on the origin of the term 'police,' I attempt to disentangle the inherent meanings of the early police concept to demonstrate how they helped shape the spine of the ideal modern politics. I then discuss the location of the police idea in the seventeenth and eighteenth centuries' search for a new governmental technology. In the second part, I discuss the reinvention of politics through the police idea, locating it as the new governing technology and definition of politics through political economy in the seventeenth and eighteenth centuries. In the final part of the chapter, I discuss primitive accumulation as an example of the ideal of political economy as the new governing technology defined by police science.

In the fourth chapter, I aim to demonstrate the mediatory role of the police of the public. In the first part, I take issue with constant primitive accumulation to reveal the secret of the commons hidden under the public-private divide, and also the secret role 
played by police science in the eighteenth-century enclosure movement. In the second part, I look at the relationship between urbanization, enclosure, and the police project in order to highlight the centrality of the public order project for the modern art of government. In the last part, I discuss the question of continuity in the police project, defining the police as a communication apparatus inevitable for the project of the public. Overall, this chapter situates policing as both a governing technology and communication apparatus for the experience of a general public, regulating communication between the governing and governed classes, and among the governed.

In the fifth chapter, I observe the role and position of the police in forming the sphere of action for the proletariat both in their neighborhoods and workplaces. This chapter aims to demonstrate the formation of the proletarian publics through the objectification practices of the governing authorities and also through the subjectification practices of the working classes themselves, in particular, in their attempts to struggle against the new police in their life worlds. In the first part, I list the distinguishing features of the proletarian public sphere. In the second part, drawing on the counter-revolutionary panic of the ruling classes, I trace how the discourse of the public was materialized in the duties of the police in the nineteenth century. In the third part, I revisit the arguments of Patrick Colquhoun with an emphasis on his definition of the public. In the last part, I try to find out how proletarian experiences were organized in relatively autonomous publics of proletarian neighborhoods. I focus on the proletarian public spheres that were organized in line with the bourgeois ideal. I look at the organization of the Penny papers of the early nineteenth century to see how the censure system functioned through the police and also 
to see how the proletarian publics developed as camps during the century and how relations evolved between the police and the proletariat.

In the final chapter, I problematize the joint action of market-publics and police in shaping and controlling proletarian leisure activities. I first try to expand the discussion on the public relevance of the market sphere. I then discuss department stores in order to understand the transformation of economic activity during the nineteenth century and the disciplining power of these new forms of market-publics. Finally, I look at the commercialization of once commonly enjoyed spaces of recreation and the functionalization of the police forces in this commercialization. The chapter aims to reveal the role of commodification and the police in market-publics and their contribution to the deformation of proletarian publics. 


\section{CHAPTER ONE}

\section{THE PUZZLING NATURE OF POLICE AND THE PUBLIC}

Concepts of the social are never fully referential, in the sense of identifying a verbal sign that stands for or refers to (and thus comes to represent) some unambiguously identifiable feature of an external reality. Rather what concepts do is to put a handle on, or give emphasis to, some aspect of the complex of interconnections and relations that constitute the social.

Alan Hunt and Trevor Purvis, 1993, "Discourse, Ideology, Discourse, Ideology, Discourse, Ideology ..."

In the late seventeenth century, when our modern governing mentality began to emerge, two concepts captured the imagination of ruling elites: the ideas of police and the public. It is in this period that the capitalist mode of production began to be consolidated and internationalized. Thus, police science, which involved questions of how a government reliant on the public could benefit from its authority, who such a government ought to target, and what it ought to instrumentalize, laid the base for governmentality for a new social order, in part through law-making. While police-both in its broadest historical sense as both a descriptor of the internal affairs of the state and in its later contemporary sense as an institution - was well defined, the concept of the public was not substantiated on any concrete basis. Rather, this "most revolutionary rallying cry of the bourgeoisie" as 
Oskar Negt and Alexander Kluge put it, ${ }^{1}$ did not go beyond philosophical discussions despite the immense space the concept occupied in political conversations. This chapter aims to untangle the puzzling nature of the concepts of both the public and the police in order to de-fetishize and de-normalize both concepts by historicizing them.

For at least two reasons, I should note that although the Foucauldian side of my arguments remain, I prefer not to use the exhausted word 'genealogy' to describe what I am attempting to do with these two concepts of police and the public. First, since it was first proposed as a research tactic by Foucault, the concept has been ubiquitously employed to describe both non-genealogical and genealogical historical analyses, creating confusion and a lack of analytic utility. It seems that anything that touches upon history is now called a genealogy so the concept has lost its defining capacity and has become misleading. Talking about power/knowledge relations, Foucault defines archaeology as his method and genealogy as his tactic. Basically, this means that evidence found through the archaeological method-such as different forms of knowledge, problematizations, eventualizations, the definitions of objects and subjects of knowledge, institutional and non-institutional techniques, and discursive and non-discursive practices—are deployed in their places in the genealogical tree using genealogical tactic. A genealogical tactic assumes that, rather than the unitary body of a theory and the hierarchical order of knowledge, the history of power/knowledge relations consists of local, discontinuous,

${ }^{1}$ Negt and Kluge, Public Sphere and Experience: Towards an Analysis of the Bourgeois and Proletarian Public Sphere, Peter Labanyi, Jamie Owen Daniel, and Assenka Oksiloff (Trans.), Minneapolis and London: University of Minnesota Press, [1972] 1993, p. 9. 
disqualified, illegitimate knowledges (in its plural). Although this does not mean that genealogy opposes the contents, methods, or concepts of a science, it opposes the power effects of a discourse considered to be scientific. ${ }^{2}$ Thus, my second point is that genealogy as a research tactic comes with a certain mentality (or philosophy if you wish) so that when someone does a genealogy of something it is only natural to expect a similar research mentality. Though it may often look like I am engaged in a form of genealogical research, I much prefer to use the words historicizing or historicity of police (power) and the public (sphere) for the purpose of this thesis. This is because, lest I further muddy the notion myself, it should be clear that I have no intention of following such a Foucauldian method exclusively.

\section{The Puzzle: Taking Police and the Public into Account Together}

The concept of police was constantly defined and projected concretely in early modern discussions among Enlightenment scholars whereas the concept of the public, although used as widely as the concept of police, was always mentioned in passing and almost always as an abstraction referring to different groups of people, places, or things depending on the context. It can be argued that while the aim of police was to be systematized as public policy, the public as a concept or addressee has never received such nuanced treatment. In this way, police became policy; that is, a way of understanding the role and capacities of government that lent itself to discussion and refinement. In contrast,

${ }^{2}$ See Foucault, "Two Lectures" in Power/Knowledge: Selected Interviews and Other Writings 1972-1977, especially pp. 83-87. 
ideas of the public seem to have always been taken for granted during the same period.

Thus, my contention is that the ideal public of the new governmental mentality gained its material basis in the nineteenth century, when a public order was actively constructed. In other words, when the tasks and authorities of the new police were defined on the bases of the public order, public heath, public hygiene, public morality and so on, it became clear that bourgeois societies, in the real terms of their material social relations comprised a multitude of public spheres, and that bourgeois politics aimed at reducing these different public spheres into a single one for the benefit of good government, and hence for the well-being of capitalist accumulation.

When the central position of the public in bourgeois societies is read through the lens of policing, the political history of modern capitalism can be understood as a history of reducing diverse public spheres to construct the bourgeois public sphere. Nevertheless, this history did not unfold without recourse to its dialectical opposite; and the process of the construction of the bourgeois public sphere involved the emergence of the marketpublic spheres as its supplement, and the proletarian public spheres as its opposite. I argue that the construction of the bourgeois public sphere evolved into a police project to maintain the hegemony of bourgeois politics, morality, and aesthetics among the nonbourgeois while aiming at ongoing formation, deformation, and reformation of the proletarian publics.

The public sphere of the bourgeois societies on which the liberal democratic 'rule of law' was assumed to be constructed has hardly had use value for the kind of politics that the majority of people, i.e. working-class people, pursue. By drawing on statements in Negt 
and Kluge's influential book, Public Sphere and Experience, which has been largely neglected in discussions on the public sphere, I follow the argument that capitalist societies consist of multiple public spheres relating one another dialectically. The model of liberal democracy, however, both in theory and practice, attempts to reduce these different spheres of experience in order to limit and better control political life. I question the ways in which the experiences rooted in diverse public spheres-particularly in proletarian public sphere- have been marginalized, excluded, dominated and finally imprisoned in one single public sphere through policing practices. In doing so, I attempt to locate the history of policing in line with this denial of manifold public spheres by disclosing the contradictory dynamics intrinsic in the systematic penalization and criminalization of certain life-styles.

In short, the main problem discussed in this thesis is understanding the historicity of the modern nation state and modern societies through the lens of the police project in orchestrating the public sphere. Such a problem immediately calls the significance of the concepts of police and the public sphere into question. From the beginning, I should indicate that despite the formulation of the main problem of this thesis, my main concern is not with the state itself but the public and the agents which, in one way or another, constitute the publics, i.e. the agents of policing that render the existence of the modern state formation possible. In asking questions about the state and police, I mainly draw on two accounts that help resituate the concept of police into critical social and political theory in a more systematic and coherent way: those of Michel Foucault and Mark Neocleous.

In his lectures on Security, Territory, Population, Foucault claims to do a genealogy of the modern state, and spends quite a bit of time talking about the police concept (or 
better the ideal) of the seventeenth century. He identifies police theories with mercantilism while discussing a breakthrough in this ideal with the emergence of the Physiocrats and their interventions in terms of économites. ${ }^{3}$ According to Foucault, in the eighteenth century, this concern for political economy replaced the police project of the seventeenth century by breaking police into different institutions (including but not limited to the modern police institution as we know it today) while also mutilating the very idea of the police state. Nevertheless, his point about how these disruptions occurred and/or what the significant reflections of these ruptures on the modern police institution and, for that matter, for modern politics have been is unclear. Despite his claims, he did not pursue these questions in his following lectures in The Birth of Biopolitics. ${ }^{4}$

Neocleous, on the other hand, in his attempt to develop a Marxist state theory in The Fabrication of Social Order, looks at the problem of police in the seventeenth, eighteenth, and nineteenth centuries. ${ }^{5}$ In contrast to Foucault, Neocleous sees a continuity with transformations through the centuries regarding the notion of police. He divides its history into three stages. The first stage precedes the Thirty Years War (1618-1648), and involves an attempt to reform the social body according to certain ends in the form of “emergency legislations" to regulate what had become disorderly or remained unregulated.

\footnotetext{
${ }^{3}$ Michel Foucault, Security, Territory, Population, Lectures at the College de France, 1977-1978, Michel Senellart (Ed.), Graham Burchell (Trans.). New York: Palgrave MacMillan, 2007, see, in particular, pp. 333-361.

${ }^{4}$ Foucault, The Birth of Biopolitics: Lectures at the College de France, 1978-1979, Michel Senellart (Ed.), Graham Burchell (Trans.), New York: Palgrave MacMillan, 2008.

${ }^{5}$ Mark Neocleous, The Fabrication of Social Order: A Critical Theory of Police Power, London: Pluto Press, 2000.
} 
The second stage appears after the Thirty Years War, and involves more systematic state intervention to build good order and general welfare. The final stage emerges in the late eighteenth century before being consolidated throughout the nineteenth century as the police of liberalism. ${ }^{6}$ In parallel to Foucault, Neocleous does not reduce police to the police in uniform, seeing the latter as only one part of the broader police project. However, his analysis is unclear regarding how these continuities occurred throughout the centuries.

I start my inquiry on police at the point where Foucault ends his lectures and where Neocleous begins his analysis. In other words, I would like to start asking questions not so much about how police is a technology of the raison d'État, as Foucault puts it at the end of his lectures, and not so much about the centrality of raison d'être of the police function for the state-i.e. fabricating social order-as Neocleous claims. Rather, I would like to start by asking questions about how the ideals of police and the public constitute the raison d'être of the modern state; how the ideal of police and the public evolved into the institutions of the police and the public sphere; and how the main principles involved in these ideals orchestrated the kind of public specific to modern politics. Through such questions, I aim to address the puzzling literature on the relationship between police and the state.

The puzzling literature on the public and the public sphere also requires attention in the same vein. The literature on the public sphere has been dominated by questions regarding the distinction between civil society and the public sphere and also by discussion

\footnotetext{
${ }^{6}$ Neocleous, The Fabrication of Social Order, pp. 5-6.
} 
on the diversity and/or the singularity of the public sphere(s). In this thesis, I prefer to ask the question in reverse: what is social about the political public spheres? I aim to do a historical reading of the political public sphere from a sociological perspective, attempting to trespass the boundaries between the social, political, and economic. Nevertheless, the question I take as my main point of departure here is less the 'whatness' of the public sphere than the 'whereabouts' of the proletarian publics in the making of the modern state. In this sense, my focus will be how to de-mystify the notion of the public sphere while searching for the formation, de-formation and re-formation of the proletarian publics in relation to the police idea and practice.

Commodification and fetishism of the public sphere in theory as well as in discursive practices have concealed the very fact that the public sphere connotes historically constructed social relations based on collective and individual experiences. In this study, I aim to shed light on the historicity of the public spheres. Emphasizing the historicity of public spheres requires an understanding of them, not as monolithic or equally balanced centers of power (from which power is distributed), but as diverse and dynamic becomings in which uneven power relations shape conduct. I intend to write a brief story of the structural formation of the bourgeois public sphere-not its trans-formation, which in itself assumes an already existing public sphere - to prove my point that the political history of modern capitalism is a history of homogenizing diverse publics to assemble the public sphere.

In this respect, a dialectical reading of the public sphere calls for a historical analysis of the police project. Police power has been the regulatory medium that defines 
the contours of the public sphere-along aesthetic, moral and politico-spatial dimensions. Police officers are social middle-men. Looking at class encounters in the formation of the public sphere through the mediation of the police in uniform and policing in general constitutes one of the main trajectories of my thesis. That is, I define policing as a structural component of modern state formation through which the spheres of political, economic and socio-cultural action have been shaped. In other words, both the broad police project, referring to the policing of the population in every sense, and the modern police institution, referring to the activities of the police in uniform, are subjects of my inquiry in so far as they shape the form of the political sphere specific to our modern bourgeois societies.

As Walter Benjamin observed, "[f]or the private citizen, for the first time the livingspace became distinguished from the place of work" by the nineteenth century. ${ }^{7}$ This breakup brought forth a nescience for the masses, not only in the sense of intellectual illiteracy and ignorance, but also in the sense of political, economic and social illiteracy and ignorance as they could no longer obtain the knowledge of how to manage their conduct without an external mediator. I therefore argue that the role of the police in this sense has become the role of a mediator. The term police has come to mean mediating between the masses and their means of subsistence (such as the means to material, cultural, religious, sanitary, and even linguistic subsistence) by organizing spaces of action, drawing limits, expanding opportunities, controlling distribution, reinforcing production, securing communication, and so on. I argue that the aim of the broader project of police is to mediate

\footnotetext{
${ }^{7}$ Walter Benjamin, "Paris_Capital of the Nineteenth Century," New Left Review 1: 48, 1968, pp. 77-88, p. 83.
} 
conduct between people out in the public.

\section{The Question of Police}

Until the late 1970s, for political and philosophical reasons, critical scholars in Europe and North America neglected research into the history of police. The police were so taken for granted as a state institution that they did not attract serious academic attention as a separate field of inquiry. Although there were a handful of studies on the history of the English police, they were not enough to form a literature. In 1938, Charles Reith complained in his book, The Police Idea, Its History and Evolution in England in the Eighteenth Century and After, that the police was not taken seriously in studies on the history of England. ${ }^{8}$ Apart from the works of early police historians W.L. Melville Lee, ${ }^{9}$ Charles Reith, L. Radzinowicz, ${ }^{10}$ and T. A. Critchley, ${ }^{11}$ no significant study was conducted on the subject of the police until the 1960s. In these classical approaches to modern police history, increasing crime rates and social disorder in the late eighteenth and early nineteenth centuries were assumed to have caused the formation of the new police force between 1829 and 1856. According to these accounts, the history of police begins with Sir Robert Peel's Metropolitan Police, seen as an effective and professional preventive police force relying

\footnotetext{
${ }^{8}$ Charles Reith, The Police Idea, Its History and Evolution in England in the Eighteenth Century and After, London, Toronto: Oxford University Press, 1938.

${ }^{9}$ W.L. Melville Lee, A History of Police in England, Montclair, N. J., Patterson Smith, [1865] 1971.

${ }^{10}$ L. Radzinowicz, A History of English Criminal Law and its Administration from 1750, London, Stevens, 1948.

11 Thomas Alan Critchley, A History of Police in England and Wales, 900-1966. London: Constable, 1967.
} 
on common law.

Describing the academic atmosphere of the time, Stanley H. Palmer states that antipolice bias on campus was just like anti-black sentiment off campus, and that "[a]s a graduate student at Harvard in the early 1970s, [he could] recall being hooted down as a 'fascist' because [he] was about to give a lecture on police history." 12 The social history literature that emerged in the late 1960s helped break this simplistic argument. Among others, works by Eric J. Hobsbawn, George Rudé, and Edward P. Thompson signaled the commencement of a new era in historical research that was to change the nature of studies in other social sciences. ${ }^{13}$ In the late 1960s and throughout the 1970s, critical (or revisionist) approaches to police history challenged the classical view. Works by Alan

12 Stanley H. Palmer, Police and Protest in England and Ireland 1780-1850, Cambridge: Cambridge University Press, 1988, p. 7.

${ }^{13}$ See Eric J. Hobsbawn, The Age of Revolution: 1789-1848, New York: New American Library, 1962; George Rude, "Protest and Punishment in Nineteenth-Century Britain" in Albion: A Quarterly Journal Concerned with British Studies, vol. 5, no. 1, Spring 1973, pp. 1-23; Edward P. Thompson, The Making of the English Working Class, London: Penguin Books, [1963] 1991. 
Silver, ${ }^{14}$ Robert D. Storch, ${ }^{15}$ John Foster, ${ }^{16}$ A. P. Donajgrodzki, ${ }^{17}$ and H. Cunningham ${ }^{18}$ emphasized the class aspect of the police by defining it as a means to build a bourgeois order for the working classes while also exploring the diverse forms of policing before the police. ${ }^{19}$ This critical approach looked at how police keep a vigilant eye on working-class leisure, disciplined the labour force for capitalist exploitation, ordered the disorderly, and consolidated bourgeois hegemony over the non-bourgeois.

Robert Reiner and Clive Emsley's later approaches to police history accepted these challenges to the classical approach while expanding their scope. ${ }^{20}$ Although they both

${ }^{14}$ Allan Silver, "The Demand for Order in Civil Society: A Review of Some Themes in the History of Urban Crime, Police and Riot" in David Bordua (Ed.), The Police: Six Sociological Essays, New York: John Wiley, 1967, pp.1-24.

${ }^{15}$ Robert D. Storch, "The Policeman as Domestic Missionary: Urban Discipline and Popular Culture in Northern England, 1850-1880," Journal of Social History 9:4, 1976, pp. 481-509; "Police Control of Street Prostitution in Victorian London: A Study in the Contexts of Police Action" in Bayley, David H. (Ed.), Police and Society, London: Sage Publications, 1977, pp. 4972; "The Plague of the Blue Locust: Police Reform and Popular Resistance in Northern England, 1840-1857" in Fitzgerald, Mike, McLennan, Gregor and Pawson, Jennie (Eds.), Crime and Society: Readings in History and Theory, London: Routledge, 1981, pp. 61-90.

${ }^{16}$ John Foster, Class Struggle and the Industrial Revolution: Early Industrial Capitalism in Three English Towns, London: Methuen \& Co Ltd., 1974.

${ }^{17}$ A.P. Donajgrodzki, “'Social Police' and the Bureaucratic Elite: A Vision of Order in the Age of Reform" in Donajgrodzki (Ed.), Social Control in Nineteenth Century Britain, London: Croom Helm Ltd, 1977, pp. 51-76.

${ }^{18}$ Hugh Cunningham, "The Metropolitan Fairs: A Case Study in the Social Control of Leisure" in Donajgrodzki (Ed.), Social Control in Nineteenth Century Britain, London: Croom Helm Ltd, 1977, pp. 163-184.

${ }^{19}$ For critical assessment of both approaches, see D.J.V. Jones, "The New Police, Crime and People in England and Wales, 1829-1888," Transactions of the Royal Historical Society, Fifth Series, Vol. 33 (1983), pp. 151-168; and David Taylor, The New Police in Nineteenth-Century England: Crime, Conflict and Control, Manchester: Manchester University Press, 1997, pp. 1-12. Jones divides the two categories as consensus and conflict approaches while Taylor divides the two as orthodox and revisionist approaches.

${ }^{20}$ Robert Reiner, “The Police in the Class Structure," British Journal of Law and Society 5:2, 1978, pp. 166-184; The Politics of the Police, New York: Oxford University Press, 2000; "New Theories 
agree on the class aspect of the police, they do not limit their approach to class conflict. Reiner, for example, expands the scope of his study to include representations of the police in popular culture products. Emsley, on the other hand, looks at the organization of the police force and conflicts among police officers themselves. Emsley's work in particular made subjugated texts and archives available. Such expansive work on the police made it possible to understand the complexity of the police institution in terms of both its practices and agents.

Over the last four decades, a relatively new body of work has emerged on the police function. Following Reiner, research on recent police/policing can be divided into roughly four categories: (1) Clifford Shearing's "transformation thesis," which makes the case that a framework based on governance of security is needed since policing has fundamentally changed since the $1960 s,{ }^{21}$ (2) Dubber's "new police science," which seeks to bring back the study of police power as governing of the state;22 (3) Richard Ericson and his followers' risk society approaches to policing, ${ }^{23}(4)$ other approaches including Pat O'Malley's post-

of Policing: A Social Democratic Critique" in David Downes, Dick Hobbs, and Tim Newburn (Eds.), The Eternal Recurrence of Crime and Control: Essays in Honour of Paul Rock, Oxford: Oxford University Press, 2010, pp. 141-182. Clive Emsley, The English Police: A Political and Social History, London and New York: Longman, 1996; The Great British Bobby: A History of British Policing from the 18th Century to the Present, London: Quercus, 2009.

${ }^{21}$ Clifford Shearing, "Policing Our Future" in A. Henry and D. Smith (eds.), Transformation of Policing, Aldershot: Ashgate, 2007.

${ }^{22}$ Markus D. Dubber, "The New Police Science and the Police Power Model of the Criminal Process," in Dubber, Markus D. and Valverde, Mariana (Eds.), The New Police Science: The Police Power in Domestic and International Governance, Stanford: Stanford University Press, pp. 107144.

${ }^{23}$ Richard Ericson and K. Haggerty, Policing Risk Society, Oxford: Oxford University Press, 1997. 
Keynesian policing, ${ }^{24}$ and approaches that take into account discussions around post/latemodernity. ${ }^{25}$

A more critical literature on police history has thus developed over the last four decades. Until the early 1990s, studies on police were confined within the disciplines of criminology and legal studies so that complexity of the subject of policing was rarely linked to broader social and political thought. After Foucault's significant lecture was published under the title of "Governmentality" in English in 1991—part of his lectures published as a whole in 2004 and translated into English in 2007 under the title of Security, Territory, Population - a new body of literature emerged on the history of police. ${ }^{26}$ In his lecture, Foucault defined police as an apparatus of the raison d'État:

It is elaborated through an apparatus (appareil) that was installed in order to make raison d'État function. This apparatus is police. It is the intervention of this field of practices called police that brings to light this new subject in this, if you like, general absolutist theory of raison d'État. ${ }^{27}$

Foucault's account provided a basis for more intense genealogical studies on police, such

\footnotetext{
${ }^{24}$ Pat O’Malley and D. Palmer, "Post-Keynesian Policing," Economy and Society 25:2, 1996. 137155.

${ }^{25}$ See for example Eugene McLaughlin, The New Policing, London: Sage, 2007.

${ }^{26}$ Michel Foucault, "Governmentality" in Graham Burchell, Colin Gordon and Peter Miller (Eds.), The Foucault Effect: Studies in Governmentality, Chicago: University of Chicago Press, 1991, pp. 87-105. Although the lecture was given by Foucault in February 1978, its true context was not clear until the lectures were published in their totality in Security, Territory, Population: Lectures at the College de France, 1977-1978, Michel Senellart (Ed.), Graham Burchell (Trans.), New York: Palgrave MacMillan, 2007.

${ }^{27}$ Foucault, Security, Territory, Population, p. 278.
} 
as Pasquale Pasquino's “Theatrum Politicum," in which Pasquino explores the role of police in the formation of city life, ${ }^{28}$ Mitchell Dean's The Constitution of Poverty, where he uses the concept of police "as a way of understanding the policies ... directed towards the Poor,"29 Jacques Donzelot's The Policing of Families, which defines policing broadly to include "all the methods for developing the quality of the population and the strength of the nation," 30 and Nikolas Rose and Peter Miller's "Political Power beyond the State," in which they make their famous case for "governing at a distance." 31 Such accounts within the field of governmentality studies have so long equated policing to the Foucauldian notion of power - first as disciplinary power, then as governmentality - that ultimately everything has been described as a police practice, and hence the real meaning of police has been lost. However, recent studies taking Foucault's complete lectures into account have expanded the scope. Exemplary here is Mariana Valverde's work on city formation and police function. ${ }^{32}$

Meanwhile, the publication of Mark Neocleous's The Fabrication of Social Order:

\footnotetext{
${ }^{28}$ Pasquale Paquino, "Theatrum Politicum: The Genealogy of Capital - Police and the State of Prosperity" in Burchell, Graham, Gordon, Colin and Miller, Peter (Eds.), The Foucault Effect: Studies in Governmentality, Chicago: University of Chicago Press, 1991, pp. 105-118.

${ }^{29}$ Mitchell Dean, The Constitution of Poverty: Toward a Genealogy of Liberal Governance, London \& New York: Routledge, 1991, p. 55.

${ }^{30}$ Jacques Donzelot, The Policing of Families: Welfare versus the State, Robert Hurley (Trans.), London: Hutchinson \& Co. Ltd., 1980, p. 6-7.

${ }^{31}$ Nikolas Rose and Peter Miller, "Political Power beyond the State: Problematics of Government," British Journal of Sociology 43:2, 1992, pp. 173-205.

${ }^{32}$ Mariana Valverde, "Police Science, British Style: Pub Licensing and Knowledges of Urban Disorder," Economy and Society 32:2, 2003, pp. 234-252; "Genealogies of European States: Foucauldian Reflections," Economy and Society 36:1, 2007, pp. 159-178; "Questions of Security," conference paper presented at the Dedication of the Richard Ericson Seminar Room, Centre for Criminology \& Sociolegal Studies, 2008.
} 
A Critical Theory of Police Power in 2000, in which he attempts to develop a general theory of police power from a Marxist perspective, ${ }^{33}$ has facilitated more systematic accounts of police history across diverse disciplines. Neocleous summarizes his account elsewhere as follows:

Police as an institution has been central to the historically massive operation on the part of the state to consolidate the social power of capital and the wage form: the police mandate was to fabricate an order of wage labor and administer the class poverty thereafter. 'Police' is therefore an important conceptual tool in grappling with the way the state administers civil society in general and the working class in particular. $^{34}$

Together, Neocleous and Foucault emancipated the field from rather Althusserian, and thus functional, approaches to police within Marxist theory, and from Weberian approaches within liberal theory. Their accounts also provided grounds to expand the scope of police studies and situate them in the broader context of social and political thought. The studies in this critical literature have given different names to their object of study, including police science, policing, police power, social control, social order, governmentality, and security. Thus, in both traditions, the term police remained either taken for granted or vaguely defined. Nevertheless, the two traditions' deficits and critiques of them have enabled a collection of distinct approaches to police to appear.

\footnotetext{
${ }^{33}$ Mark Neocleous, The Fabrication of Social Order: A Critical Theory of Police Power, London: Pluto Press, 2000.

${ }^{34}$ Neocleous, "Theoretical Foundations of the "New Police Science,"” p. 21.
} 
In recent work on police/policing there is still not much consensus on several fundamental issues concerning the operational definition of the concept, such as what police means, what limits can be drawn for police functions in society at large, how far back the history of police goes, what the suitable scale of inquiry is for studying policing. Although each study has partly answered such questions, they have had to be re-defined in each study. The question still begging an answer is this: How is it that a subject matter that has continued to be the subject of grand Enlightenment discussions in both England and continental Europe, and that has also been embodied in the concrete institution of the police since the $1800 \mathrm{~s}^{35}$ - making it open to case/field studies — can have so many meanings attributed to it that each new study can re-define the meaning of the subject matter.

One reason may relate to the diverse disciplines working on the issue, primarily sociology, political science, criminology, history, and cultural studies. This creates two practical problems for the general study of police. First, each discipline has different approaches to the problem: although not so distinct, each discipline pretends that its approach is distinct. ${ }^{36}$ Second, each focuses on the police concept in accordance with its particular needs. In response to this diversity, my thesis tries to locate police as an inter-

\footnotetext{
35 Neocleous demonstrates that only in German-speaking areas "a 1937 bibliography listed no fewer than 3,215 titles published between 1600 and 1800 under the heading "science of police in the strict sense', and it has more recently been claimed that there are some 14,000 cameralist tracts." See Neocleous, The Fabrication of Social Order, p. 12, see also footnote 35.

${ }^{36}$ I believe that Bourdieu's notion of distinction fits with distinctions among academic disciplines better than anything else. Pierre Bourdieu, Distinction: A Social Critique of the Judgement of Taste, London and New York: Routledge, 1984. In today's world, where universities are increasingly turning into corporations, each academic discipline is trying to secure its own institutionalization within the bigger corporation of university. Diversity in academia in approaching the topic of police and policing should be reconsidered in this context.
} 
disciplinary concept that benefits from each discipline, and in turn has a use for each discipline.

Another main reason is that the idea of police and the reality of it are different, as in the case of every idea and practice. There are two main difficulties that make any study on police specifically problematic in this sense. The first is the gradual transformation of the idea and practice of police over the centuries. When it first emerged from the FrenchBurgundian policie in the fifteenth century, the term referred to "a condition of order in the community" or "statute aimed at the institution and/or maintenance of order in the community." ${ }^{37}$ This definition relied mainly on translations of Ancient Greek texts, specifically those of Plato and Aristotle, and related to the political community, i.e. polis (ancient Greek city-state). As Emsley puts it,

The Greek politeia meant all matters affecting the survival and well-being of the state (polis). The word and the idea were developed by the Romans (the Latin politia can be translated as the state), largely disappeared with their Empire, but were resurrected in the medieval universities to justify the authority of a prince over his territories..$^{38}$

In the seventeenth century, however, the term was ascribed a new meaning in a different formation with a different objective within the emerging domain of the 'science of police' (Polizeiwissenchaft). While the term previously defined the state of order, the

\footnotetext{
37 Franz-Ludwig Kneyemer, "Polizei," Economy and Society, Vol. 9, No. 2, May 1980, pp. 172196.

${ }^{38}$ Emsley, The English Police, p. 3.
} 
science of police became more concerned with the content of this order as well as how to achieve this order. ${ }^{39}$ The science of police, in other words, became concerned with the objectives and the function of the state and its institutions. The term 'police,' in its seventeenth-century origins, is therefore strongly related to the reason d'etre of the state and the new mode of production it perpetuates.

In the nineteenth century, we see the coming of the uniformed police force as we understand it today. First, in France under the rule of Napoleon Bonaparte, then in England under the rubric of the 'New Police,' the uniformed body of centralized police emerged, which excludes the earlier broad meanings regarding the totality of the internal affairs of the state. It is this narrowing down of the content of the concept of police that creates some of the confusion in current studies concerning police. When scholars talk about police, it is hard to differentiate if they refer to the broader notion of police identified with the state (as the composition of governors, population, and territory) or to the uniformed body of police-which, despite its broader functions in building the modern order cannot be equated to all the functions regarding the state. While some acknowledge a rupture between the two meanings, others see a continuity in these changing meanings and practices of police.

The second difficulty emanating from differences between the ideal and the practice of police is a more practical one that can be related to notions intrinsic in the police concept:

39 For an extended discussion on the origins of the term "police" see Knemeyer, "Polizei," pp. 172173; and Neocleous, The Fabrication of Social Order, pp. 1-10; and also Pasqulino, "Theatrum Politicum: the Genealogy of Capital." 
security, crime, punishment, discipline, the well-being of the population, and social order. All these notions have normative meanings attached to them that make any critical study of police even more difficult. The problem with normativity is that no matter how much one criticizes police and related terms, the popular consensus, or better common sense, still deems police as a good thing that is necessary to protect the good from the bad. Throughout their history, police forces have functioned in a multi-faceted manner, "used by ... all classes to oppose each-other, to co-operate with, and to gain concessions from, each other." ${ }^{40}$ This practical function for all social classes along with the fetishized imagination of the police makes it difficult to imagine a world without them despite their rather short history. To overcome this difficulty, this study explores the history of police science in order to reveal the roots of this normativity and thus to de-fetishize the notion of police.

\section{The Question of Public}

Since Jürgen Habermas proposed the term public sphere in his influential work, The Structural Transformation of the Public Sphere, the concept has largely become a phrase that no longer just explains things but is itself also explained from different angles. ${ }^{41}$ This is not to say that Habermas was the first to theorize the term as significant earlier attempts to understand the concept were made in W. Lippmann's The Phantom Public in 1925 and

\footnotetext{
40 See Emsley, The English Police, pp. 5-6. Although Emsley accepts the coercive power of the police, he rejects the idea that equates the police to a simple means for class oppression, emphasizing instead the "use-value" of the police for all classes.

${ }^{41}$ Jürgen Habermas, The Structural Transformation of the Public Sphere: An Inquiry into a Category of Bourgeois Society, Thomas Burger (Trans.), Cambridge: MIT Press, [1962]1991.
} 
J. Dewey's The Public and its Problems in $1946 .{ }^{42}$ What made Habermas's approach to the public sphere significant, however, was the way in which he historicized the term, thereby making it a notion that should itself be investigated. Lippmann and Dewey, however, focused more on what the public should look like rather than what the public or the public sphere is and how it became one.

Habermas's historicization of the term has been welcomed by diverse disciplines in the social sciences. Starting with the early 1990s, when Habermas's book was translated into English and introduced to English-speaking academia, the concept of the public sphere became increasingly popular in the social sciences. Its revival was reflected in real politics as well with discussions in Europe on establishing a European public sphere. The concept was frequently referred to during attempts to create a European Union constitution, with Habermas himself becoming actively involved. ${ }^{43}$

The collection of essays edited by Craig Calhoun, Habermas and the Public Sphere, reflected the interdisciplinary influence of Habermas's work in the English-speaking world, so much so that the collection was claimed to be "more directly responsible for the development of subsequent work on the public sphere, at least in the English-speaking world, than the original study which inspired it." ${ }^{\prime 4}$ Alex Benchimol and Willy Maley

42 W. Lippmann, The Phantom Public, Transactions Publications, [1925]1993; John Dewey, The Public and its Problems, Swallow Press, [1946] 2006.

${ }^{43}$ For one of his commentaries on the issue, see Habermas's extensively discussed article on the EU Constitution referendum: Habermas, "The Illusionary Leftist "No": Adopting the Constitution to Strengthen Europe's Power to Act", 12.10.2012 http://www.signandsight.com/features/163.html.

${ }^{44}$ Alex Benchimol and Willy Maley, Spheres of Influence: Intellectual and Cultural Publics from Shakespeare to Habermas, New York: Peter Lang, 2007, p. 11. 
summarize how Habermas's work has influenced research in diverse disciplines and paved the way for inter-disciplinary studies in the last four decades since its first publication. ${ }^{45} \mathrm{I}$ draw on this Habermasian literature in the next chapter in more detail. For now, it should suffice to indicate that part of my goal in this thesis is to re-assess arguments concerning the history of the public sphere in these Habermasian accounts. Commencing with various definitions of the public sphere, I aim to re-conceptualize the term by emphasizing the multiplicity of public spheres in capitalist societies. In doing so, my main concern is to lay out the possibilities to re-contextualize the problematization of public spheres in accord with broader social history studies while benefitting from the discussions opened up by Habermasian scholars.

I argue that a new conceptualization, and thus investigation, of public spheres has a lot to say about the construction and operation of modern societies, mainly because such an inquiry takes into account the ways in which public spheres have been defined, discovered, invented, fabricated, and ultimately orchestrated throughout the history of modern societies. The question of how diverse public spheres have been formed can be linked to structural changes in the economic context, without letting one slip back into economic determinism. It can also be linked to cultural phenomena, in particular to popular culture, without letting one slip back into cultural reductionism. It can be linked to transformations in governmental practices, without letting one slip back into the so-called distinction between the state and civil society. It can be linked to moral reforms, without

\footnotetext{
${ }^{45}$ Alex Benchimol and Willy Maley, "Introduction: circling the public sphere" in Benchimol and Maley (Eds.), Spheres of Influence: Intellectual and Cultural Publics from Shakespeare to Habermas, Oxford: Peter Lang AG, 2007, pp. 9-40.
} 
letting one slip back into moralist discourse. It can also be linked to the transforming force of aesthetic reformation without letting one slip back into elitist avant-gardism.

At the risk of revealing the end of my thesis, I should identify here some of the promises this re-conceptualization relies on. First, it should be acknowledged that there are multiple public spheres even though the project of the Enlightenment assumed and attempted to impose the public sphere. Second, it should be kept in mind that public spheres are not 'end products' in which citizens should be encouraged to participate; rather, they are always in the making. Third, one should not only look at how public spheres unite people but also look at how they divide people, in that they both pit some against others and divide the very subjectivity of a person. Fourth, because of these dividing practices inherent in diverse public spheres, it is always possible to talk about public spheres entwined together. In other words, it is not possible to differentiate one public sphere from another through demarcated borders; instead, they are always produced within and/or producing counter-publics.

Fifth, although public spheres indicate spaces, both physical and non-physical, they should not be considered as spaces mediating between two other spaces, such as people and the state, family and the market, life worlds and others. They should rather be considered as spaces in which mediations are realized between subjects and their selves, subjects and others, subjects and their material world. In other words, they are the spaces of socializing, conducting, interacting, and exchanging with our selves, with others, and with the material world. To put it more clearly and more soundly within the scope of this thesis, public spheres are spaces in which people obtain life experiences and in turn form 
new publics. In relation to this point, my sixth point is that public spheres themselves are not the mediators; rather, they are the spaces in which various mediators act through relations-mediators such as police, schools, advertising and marketing agents, religion and leisure. And finally, seven, these mediators located in public spheres are themselves in the making, while they are also making public spheres the places of experience in line with dominant ethics, aesthetics, and politics.

I should also note that within the scope of this thesis I am not looking at how to differentiate better the private from the public; I am not looking at how to understand the public to improve modern capitalist democracies; I am not looking at how to demarcate the borders of freedom in the public sphere to enable perfect political involvement - if one can talk about such perfection - and for that matter I am not looking at how to emancipate the public sphere from colonization by the free market. Instead, I am trying to identify diverse public spheres in their dialectical relation to each other. In that, I am also looking at how the counter-public realms of the proletariat have been produced, subjugated, oppressed, transformed, neutralized, and neglected. In this sense, what I call public spheres should be understood in relation to experience and forms of conduct. Thus, I will be looking at the realms where this experience is mediated or remains unmediated-which is of course the terrain of police.

\section{Scale, Scope and Limitations}

In sum, this thesis looks at the ways in which the ideals of police and the public since the late seventeenth century have constituted the raison d'être of the modern state, and also the ways in which the projects of the police and the public sphere as practiced in 
the early nineteenth century worked in tandem to shape political subjects consistent with the capitalist mode of production. In so doing, I seek to understand the ways in which a revolutionary working class consciousness first appeared in the first half of the nineteenth century then faded away in the second half in relation to the police and the proletarian public sphere. In doing this, the objective of my thesis is to develop an historical understanding of the role of modern police in the formation, de-formation, and reformation of spheres of action, i.e. the public spheres.

Such an objective requires presumptions acknowledging the historicity of the notions of both police and public spheres rather than a history of the police and the public sphere. My subject of inquiry requires two levels of analysis: the historicity of the police idea and the ideal of the public; and the social history of the relationship between the police and diverse publics. Regarding these twofold analyses, I should make some comments about the method of my project. It is difficult to write about my methodology for at least two reasons.

First, I doubt that it is possible to maintain a single consistent research methodology in social sciences since knowledge production is a complex issue that cannot be reduced to one coherent methodology objectifying the subject matter with claims to reaching some explicit, precise knowledge of complex, multi-layered social relations. My resistance to consistent methodology is not as strong as that of Barry Hindess, for example, who claims "there can be no rational or coherent prescriptive methodology." 46 Yet, I support his stance

\footnotetext{
${ }^{46}$ Barry Hindess, Philosophy and Methodology in the Social Sciences, Sussex: The Harvester Press, 1977, p. 2.
} 
in claiming that methodologies are based on the unjustified presumption of a rationalist, coherent, consistent conception of social action. The second difficulty lies in the aim of my project. With this thesis, I aim to propose a way to study the role of police and public spheres in capitalist societies. Rather than a method, I aim to highlight certain aspects of social relations relating to the projects of police and the public to understand how the kind of politics specific to modern societies operates. The current work, in this sense, is organized around finding a better research strategy to understand the relationship between the formation of the publics and the police function. Therefore, rather than using a methodology, my study aims to offer a research strategy.

Despite these difficulties, some of the principles that I hold can be listed as follows. First, despite my claim above, I do not deny that class structure and uneven power structures exist in our societies; rather, I suspect that every social relation can be explained with reference to social structuration. Second, accepting that social action is not always rational, coherent, or consistent does not mean denying that rationalized, somewhat consistent, carefully planned 'projects' of governance exist, with particular targets, agents, means, technologies, and strategies. On the contrary, in this thesis, I search for the social and political effects of just such 'projects' of police and the public sphere in bourgeois societies. ${ }^{47}$

Third, these projects are always incomplete, producing unintended consequences

\footnotetext{
${ }^{47}$ I follow here and in the following point the line of argument Alan Hunt puts forward in his analysis of Foucauldian governmentality. See Hunt, "The Governance of Consumption: Sumptuary Laws and Shifting Forms of Regulation" and "Governing the City: Liberalism and Early Modern Modes of Governance."
} 
due to the resistance of the governed, which leads to them being altered, abandoned, or significantly changed depending on the response. As Alan Hunt puts it, "governance is an ongoing set of practices that persists until its target or object undergoes some significant change towards a reconstructed object or, alternatively, abandoned." 48 Fourth, looking at these operations, their objectives, targets, and results means also looking at resistance to regulations, thinking of them not one-sidedly but in terms of mutuality. Fifth, Marxian class formation and Foucauldian power relations are central to my thesis, on the condition that the concepts of experience, moral regulation, and relative autonomy constitute the main trajectories for understanding both class formation and the power relations inherent in the projects of police and the public.

Sixth, I agree that "what concepts do is to put a handle on, or give emphasis to, some aspect of the complex of interconnections and relations that constitute the social."49 Therefore, I do not claim that the concepts of police and the public sphere refer to some perfectly identifiable external reality in history. Instead, they help me emphasize certain aspects of police function in current socio-political reality. In that, I rephrase Pascal Pasquino's formulation referring to Foucault's work on punishment by imprisonment to argue that (by replacing 'the prison' with 'police and the public sphere' in square brackets)

we should not endeavor to explain modern societies by way of [police and the public sphere], but should attempt instead to see in what ways [police and the public

\footnotetext{
${ }^{48}$ Hunt, "The Governance of Consumption: Sumptuary Laws and Shifting Forms of Regulation," p. 412.

${ }^{49}$ Alan Hunt and Trevor Purvis, "Discourse, Ideology, Discourse, Ideology, Discourse, Ideology ...", The British Journal of Sociology 44:3, 1993, p. 474.
} 
sphere] is consistent with modern societies, without then reducing this consistency to an identity. ${ }^{50}$

This is because, in the eighteenth century, not only were the apparatuses of the modern state functionalized, but also, and more importantly, the tactics of scientification and aestheticization for the sake of regulation were used to pacify the masses. The apparatus of the modern state was shaped accordingly.

At this point, I should immediately note, although I am strongly committed to both Marx's and Foucault's analyses, I do not claim that my work exemplifies a Marxist or Foucauldian approach to the police and the public sphere. This commitment reveals itself most in the way in which I approach the subject matter. That is to say, throughout this thesis, I will be looking at material social relations as they unfold in discursive and nondiscursive practices. In so doing, however, I do not equate the mode of production with the relations of production. Neither do I equate disciplinary power relations with police power at the expense of neglecting exploitative class relations. Instead, I look at relations between workers-as-subjects in their non-working time and space with reference to their public action and interaction with the police. However, I do not reject the dialectical component inherent in social relations, although such dialectics should not be read as mechanical. They rather resemble Foucault's insistence on power/resistance; that is, power relations necessarily include resistance.

Although the subject matter of my thesis involves the history of ideas and social

\footnotetext{
${ }^{50}$ Pasquale Pasquino, "Michel Foucault (1926-84): The Will to Knowledge," Chloe Chard (trans), Economy and Society 15(1), 1986, p. 97.
} 
history, I have no intention to act as a historian. My aim is rather to understand today's politics through de-mystifying its major components: i.e., the public sphere and the police function. In this, I agree that "historical processes move in such a manner that long-run trends interact with faster-moving and more deliberate processes." ${ }^{.51}$ Through revealing these historical (dis)continuities in the modern projects of police and the public I try to develop an understanding of the present struggles. That is, my attempt corresponds to Perry Anderson's observation that "[ $[\mathrm{t}]$ heory is now history, with a seriousness and severity it never was in the past; as history is equally theory, in all its exigency, in a way that it typically evaded before." 52

Zygmunt Bauman makes the case in Modernity and the Holocaust that fascism in modern times is no accident. ${ }^{53}$ While the executive power of governments expands more and more in neoliberal times, it is apt to keep Bauman's warning in mind. It is important to understand the formation and re-formation of the sphere of political action, i.e. the public sphere and the role of the police in this process, to comprehend both the value of alternative publics and also the decline in political participation. That is, historicizing police power and the public sphere is needed today more than ever as common sense defines the police as an ahistorical and omnipresent institution, restricting its function to the so-called need for security.

Foucault defines the main characteristic of our political rationality as both

\footnotetext{
${ }^{51}$ Hunt, Alan, "Police and the Regulation of Traffic," p. 171-172.

52 Perry Anderson, In the Tracks of Historical Materialism, London: Verso, 1984, p. 26.

${ }^{53}$ Zygmunt Bauman, Modernity and the Holocaust, Cambridge: Polity, 1989.
} 
individualizing and totalizing. ${ }^{54}$ Hunt makes the case that a communicative activity (such as driving) can lead to more and more individualization and totalization at the same time as long as it depends on knowing and predicting the behaviours of others. ${ }^{55}$ Accordingly, I argue that the totalizing effects of modern government are impossible without individualizing effects. These two had to go hand in hand in the police project in order to achieve the most desired mode of communication among citizen-subjects in the public sphere-i.e. appearing as independent persons in public while being just one among many others who are assumed to behave in a certain way. The police function aims to transform those aspects of social life where experience is organized through civilizing offensives, reform of popular culture, and moral regulation projects.

Both the police and the public sphere are modern notions, derived from Enlightenment ideals, and that they should be understood as such-along with their compliance with the capitalist mode of production. That is, even if the capitalist mode of production was overthrown, our societies would not be free of these notions. Indeed, exactly the opposite occurs, as the history of real socialisms has shown us. In this thesis, I also try to expose the contradictory relationships between modernity, capitalism, police, and the public sphere, and emphasize the need to recognize the role of police in the reinvention and re-activation of the political sphere in modern societies. In his discussion on

\footnotetext{
${ }^{54}$ Michel Foucault, "The Subject and Power," in Hurley, Robert and others (Trans.), James D. Faubion (Ed.), Power: Essential Works of Foucault 1954-1984, vol. III, New York: The New Press, [1982] 2000.

${ }^{55}$ Alan Hunt, "Police and the Regulation of Traffic: Policing as a Civilizing Process?" in Dubber, Markus D. and Valverde, Mariana (Eds.), The New Police Science: The Police Power in Domestic and International Governance, Stanford: Stanford University Press, 2006, pp. 168-184.
} 
the problems surrounding the notion of democracy within Marxist theory, Hunt criticizes the Leninist perspective on politics and democracy, arguing that "[w]hat is absent from Lenin is any recognition of the contradictory character of bourgeois democracy." ${ }^{\circ 6} \mathrm{He}$ then quotes from Marx's Class Struggles in France:

The comprehensive contradiction of this constitution, however, consists in the following: The classes whose social slavery the constitution is to perpetuate, proletariat, peasantry, petty bourgeoisies, it puts in possession of political power through universal suffrage. And from the class whose old social power it sanctions, the bourgeoisie, it withdraws the political guarantees of this power. It forces the political rule of the bourgeoisie into democratic conditions, which at every moment help the hostile classes to victory and jeopardise the very foundations of bourgeois society. ${ }^{57}$

Hunt further suggests that "[p]olitical competition, representative government, political rights do not bear an ahistorical capitalist essence but provide elements whose transformation makes possible the attainment of the socialist project." ${ }^{58}$ He claims that "the sphere of democracy, which concerns the extension of human control over the social conditions of existence, lays down elements which have to be liberated from their limitation and distortion under capitalism." ${ }^{59}$ Part of the aim of my thesis to trace how the

\footnotetext{
${ }^{56}$ Alan Hunt, "Introduction: Taking Democracy Seriously" in Alan Hunt (Ed.), Marxism and Democracy, London: Lawrence and Wishart, 1980, p. 13.

${ }^{57}$ Karl Marx, quoted in Hunt, “Introduction: Taking Democracy Seriously,” p. 13.

${ }^{58}$ Hunt, "Introduction: Taking Democracy Seriously," p. 17.

${ }^{59}$ Hunt, "Introduction: Taking Democracy Seriously," p. 17.
} 
sphere of democracy, i.e. the public sphere, carries and sometimes ceases to carry these elements for transformation. Dividing the category of the public sphere into three components, namely bourgeois, proletarian, and market public spheres, I will demonstrate how the values, morals, and cultures of one sphere have affected the others, and in turn, how these values, morals, and cultures have been governed through the interventions of the police apparatus.

\section{Conclusion}

The internal contradictions of modernity in general, and bourgeois democracy in particular, allow me to still believe in the revolutionary potential of the public sphere in general, and proletarian publics in particular. Nevertheless, interventions in the proletarian way of life with the target of making it resemble the bourgeois way of life, and with the target of submerging it in the charming sea of market-based values, have decreased such potential. Given this, it is important to note the ways in which this potential has been minimized, and also the ways in which the working classes have fought back against such interventions. I aim to highlight the importance of the not necessarily economic but moral and cultural value-based motivations that bring the working classes together. In other words, I will deal with the question of the moral economy of the working classes or the question of governing morals from a different angle: the angle of the police and the public sphere. In so doing, I will be stealing a lot from feminist theory in general while emphasizing the revolutionary potential of the public only insofar as subjects appearing in public can bring their own experiences with them; in other words, can act in a way in which the "personal is political." 


\section{CHAPTER TWO}

\section{A SOCIAL NARRATIVE OF THE POLITICAL PUBLIC}

The standpoint of the old materialism is civil society; the standpoint of the new is human society or social[ized] humanity.

Karl Marx, $10^{\text {th }}$ Thesis on Feuerbach

Taking social humanity, or rather socialized humanity, as the standpoint of any inquiry requires meticulous attention to the physical and non-physical space in which people socialize because the ways in which people socialize, and come into contact with each other, with their selves, and with their material world can be revealed in reference to space. Despite Marx's claim, quoted above, the answers to these questions have long been discussed around the concept of civil society in both Marxist and non-Marxist social and political thought. Since Jürgen Habermas first proposed the term public sphere in his influential work, The Structural Transformation of the Public Sphere as an alternative, in addition rather than opposition to civil society, the concept of the public sphere has, to a great extent, become the main phrase that no longer just explains things but is also explained from different perspectives by scholars from diverse disciplines. ${ }^{1}$

Departing from such diverse approaches to the concept, this chapter aims to recontextualize the political concept of the public (sphere) in order to provide it with a socio-

\footnotetext{
1 Jürgen Habermas, The Structural Transformation of the Public Sphere: An Inquiry into a Category of Bourgeois Society, Thomas Burger (trans.), Cambridge: MIT Press, 1991 [1962].
} 
historical narrative. With this aim in mind, I first take issue with the ways in which the public and the public sphere have been problematized in the history of social and political thought, in particular in (and with reference to) Enlightenment thought. In so doing, I draw mainly on the works of Immanuel Kant, Hannah Arendt, and Habermas. In the second part, I offer a critique of the bourgeois public sphere as problematized by Arendt and Habermas. In this critique, I mainly refer to historical accounts by Richard Sennett, Michael Warner, Robert D. Storch, and Craig Calhoun. In the third part, I define market-public spheres by drawing on Oskar Negt and Alexander Kluge's definition of the "new public spheres of industrial production." In this part, in opposition to Habermas and others who situate the market as an obstacle to realizing the full potential of the public sphere, I try to reveal the publicity of these market-public spheres in the history of capitalist societies. In the fourth part, I try to develop Negt and Kluge's idea of proletarian public spheres by first demonstrating the deficits in their attempt to define and contextualize the term and then historicizing the proletarian public.

\section{The Destiny of the Public Sphere as an Enlightenment Project}

The organization of modern state and society has been widely discussed around the distinction between public and private realms. As Habermas notes, these are in fact "categories of Greek origin transmitted to us bearing a Roman stamp," and that, from the Greeks to the modern day, the ideal of the public sphere has existed not so much as "the social formation at its base" but rather as "the ideological template" on the level of 
intellectual history. ${ }^{2}$ It is important for our inquiry, then, to trace the history of the term in European social and political thought. The term public sphere took its modern form with the differentiation of civil society from the state in the late seventeenth and early eighteenth centuries in Europe. Prior to this period, the state or political authority was identified with its body, i.e. the people; hence the political and social realms were rarely distinguished. When they were, the social was identified with the family and seen as the realm of mere reproduction and necessity. The Greek conception of the polis, for example, treated this realm of necessity, i.e. the private realm involving economic activity, as inferior to the public realm, which was associated with affairs of state. ${ }^{3}$

The notions of the public good and public administration (identifying the 'public' with the 'common good' in society) had appeared in English by the late fifteenth century. Securing the public good (res publica or commonwealth) was understood as the responsibility of the monarch, who was assumed to have 'two bodies': his/her private person and his/her 'public' being as the sovereign ruler. Monarchs consulted other nobles with public roles, but also with a growing number of commoners who had begun to hold public offices. In the middle of the sixteenth century, a sense of 'public' meaning 'manifest and open to general observation' was added to the term. By the end of the seventeenth century, the modern distinction between public and private was defined by European philosophers. $^{4}$

\footnotetext{
${ }^{2}$ Habermas, The Structural Transformation of the Public Sphere, pp. 3-4.

${ }^{3}$ See Hannah Arendt, The Human Condition, pp. 29-31.

${ }^{4}$ For a historical inquiry of the term's early modern usage, see Craig Calhoun, "Civil Society/Public Sphere: History of the Concept(s)" in International Encyclopedia of the Social and Behavioral
} 
Along the path from Luther and Calvin to Hobbes, says Habermas, "the Reformation's distinction between the regnum spiritual and the regnum politicum shifted in meaning and came to refer to the inner-worldly opposition of a privatized society to political authority, of society to government." 5 Hobbes was among the first who identified 'conscience' with 'opinion.' ${ }^{6}$ According to Habermas, "Hobbes's devaluation of religious conviction actually led to an upward evaluation of all private convictions." ${ }^{7}$ In other words, the privatization of religion and property increased the value of people's private opinions. In An Essay Concerning Human Understanding (1690), John Locke defined "the law of opinion" as a category with equal rank beside divine law and civil law. ${ }^{8}$ For Locke, the law of opinion was established by the "secret and tacit consent" of individuals without measuring virtues and vices. ${ }^{9}$ Locke's definition here is significant in two senses. First, he underlines society's self-organizing potential rather than the idea of a society organized by rulers. This understanding is crucial because it creates a basis for later definitions of civil society as a notion organized by the 'invisible hand' as well as civil society as a 'claim of

Sciences, Amsterdam: Elsevier, 2001, pp. 1897-1903; and Calhoun, "Public" in T. Bennett and L. Grossberg (eds.), New Keywords, Buckingham: Open University Press, 2004; Richard Sennett, The Fall of Public Man, New York and London: Norton \& Company, 1992, especially pp. 16-24; Habermas, The Structural Transformation of the Public Sphere, especially pp. 1-27.

${ }^{5}$ Habermas, ibid., p. 91 see footnote 8.

${ }^{6}$ Hobbes, Leviathan, London: Penguin Books, 1985 [1651], p. 366. Though Hobbes does not necessarily differentiate "public" from a mere summation of individuals, he draws here a slight distinction between public and private opinions. "The law is the public conscience", he states, and even though one's own conscience contradicts with it, he should comply with the law for the sake of the Commonwealth not to be distracted - which would eventually end all individual consciences.

${ }^{7}$ Habermas, The Structural Transformation of the Public Sphere, p. 91.

${ }^{8}$ Locke, An Essay Concerning Human Understanding, chp. 28, section 7, p. 242.

${ }^{9}$ Locke, ibid., chp. 28, section 10, p. 243. 
civility' against the claims of nature. ${ }^{10}$ Second, as Habermas points out, opinion here "denoted the informal web of folkways whose indirect social control was more effective than formal censure." 11 So much so that Locke calls it the law of "private censure."12 Therefore, following Hobbes, for Locke, 'opinion' came to have a status that could no longer be undermined in modern political thought.

In 1750, Rousseau used the term opinion publique for the first time in Discourse on the Arts and Sciences. He sought to understand how social unity could be established on the basis of 'free will' rather than constraints external to society or mere human instincts in the Aristotelian sense. The term was translated into English both as 'public spirit' and the 'sense of the people.' ${ }^{13}$ The latter term was used to create a basis for connecting political opposition with the larger mass of the population. Though it still retained traces of 'immediacy' — that is to say, it did not yet require the precondition of reasoning - it was used by the opposition as a justification. In 1730, the English Tory leader, Bolingbroke, claimed that "if all men cannot reason, all men can feel." ${ }^{14}$ In 1777, Edmund Burke referred to the public spirit as "general opinion," declaring it was the "vehicle and organ of

\footnotetext{
${ }^{10}$ For a brief discussion on the conceptualization of society's self-organizing potential from social contract theorists to Hegel, see Calhoun, "Civil Society/Public Sphere: History of the Concept", p. 1898; and Calhoun, "Civil Society and the Public Sphere" in Public Culture 5, 1993, pp. 267-280, see especially pp. 270-271. For a discussion on the public sphere's claims of civility as opposed to the private realm's claims of nature in terms of reproduction of life see Sennett, The Fall of Public Man, pp. 18-19.

${ }^{11}$ See Habermas, The Structural Transformation of the Public Sphere, p. 91.

${ }^{12}$ Locke, An Essay Concerning Human Understanding, chp. 28, section 12.

${ }^{13}$ Habermas, The Structural Transformation of the Public Sphere, pp. 92-93.

${ }^{14}$ Bolingbroke, cited in Habermas, ibid., p. 93.
} 
legislative omnipotence." ${ }^{15}$ Before using this phrase, however, Burke had introduced the representative public in a speech to the electors of Bristol in 1774 in which he defined parliament as "a deliberative assembly of one nation, with one interest, that of the wholewhere not local purposes, not local prejudices, ought to guide, but the general good, resulting from the general reason of the whole." 16 Here, the use of 'general reason' distinguishes his definition from both Bolingbroke's 'sense of people' and Locke's 'law of opinion' since Burke clearly assumes that public discussion is necessary to develop general opinion. He also views this public discussion as a precondition for freedom: in free countries, he says, "there is often found more real public wisdom and sagacity in shops and manufactories than in the cabinets of princes in countries where none dares to have an opinion until he comes into them." 17

In mid-eighteenth-century France, the Physiocrats were the first to argue that civil society has laws of its own as opposed to state intervention. In this period, opinion publique gained the meaning of "an opinion purified through critical discussion" in the public sphere. ${ }^{18}$ As Marx describes it, the doctrine of the Physiocrats "amounted to a bourgeois reproduction of the feudal system" because, for them, scholars should determine public opinion for governors to put into practice. As Habermas shows in his comparison:

\footnotetext{
${ }^{15}$ Edmund Burke, cited in Habermas, ibid., p. 94.

${ }^{16}$ Burke, "Speech to the Electors of Bristol, On His Being Declared by the Sheriffs Duly Elected One of the Representatives in Parliament for that City" in The Works of the Right Honourable Edmund Burke, Vol. II. (of 12), The Project Gutenberg E-Book, released in 2005. Retrieved on 10.11.2012. http://www.gutenberg.org/files/15198/15198-h/15198-h.htm.

${ }^{17}$ Burke, cited in Habermas, The Structural Transformation of the Public Sphere, p. 94.

${ }^{18}$ Habermas, ibid., p. 95.
} 
whereas the British contemporaries understood the public spirit as an authority that could compel lawmakers to legitimize themselves, in France the continuing isolation of society from the state manifested itself in the fact that...the critical function of opinion publique remained strictly separated from the legislative function. ${ }^{19}$

Nevertheless, the dominant usage of the term in the eighteenth century, both in England and France, emphasized freedom of expression of one's opinion in plurality through engaging in critical discussion with others. It is with this meaning that the term 'public opinion' was contrasted to the absolutist repression of the state, and the idea of people as acting subjects came to the fore in European political thought.

Kant saw publicity as the bridging principle between politics and morality, to rationalize politics in the name of society. In the eighteenth century, Habermas notes, Aristotelian political philosophy was reduced to moral philosophy while the moral encompassed the emerging sphere of the social. ${ }^{20}$ Understood in this context, Kant's principle of the public sphere aimed to both integrate and separate politics and society. In "What is Enlightenment?," Kant defined it as "liberation from the self-incurred tutelage."21 This process worked in two ways: the individual's enlightenment as a subject thinking for himself, and humanity's enlightenment in progressing towards a perfectly just order. In

\footnotetext{
${ }^{19}$ Habermas, ibid., p. 96.

${ }^{20}$ Habermas, ibid., p. 103. Habermas also notes that this is why Adam Smith as the author of the Wealth of Nations held a Chair of Moral Philosophy.

${ }^{21}$ Immanuel Kant, "Was ist Aufklärung?" [1784] in Michel Foucault, The Politics of Truth, Sylvère Lotringer (ed.), Los Angeles: Semiotext(e), 2007, pp. 29-39.
} 
both cases, the public use of reason, in other words, critical reasoning mediated within the public sphere, constituted the very condition for Enlightenment: "[ $[$ the public use of one's reason must always be free, and it alone can bring about enlightenment among men."22

Kant defined the specific sociological conditions of the bourgeois public sphere by differentiating private interests from public benefits and constraining them within separate spheres of activity— such as the public and private use of reason, civil freedom and freedom of mind, spheres of obedience and arguing. Although Kant initially viewed the public use of reason as a matter for scholars, his call later turned out to be for all who 'dare' to know and emancipate themselves from their private confinements. In this sense, Kant spoke of the public sphere as the 'world' and referred to the 'man of the world. ${ }^{23}$ His was an ideal of a world constituted through rational-critical discussions among free, educated men (not women).

Overall, for early modern and Enlightenment thinkers, the notion of the public sphere as arena of rational-critical debate arose from problematizing the form and matter of civil society: that is, querying the ways in which the tutelage of the masses (with unexamined traditions and unmediated passions) and the tutelage of political actors (with potentially unlimited power and undispersed authority) could be overcome. ${ }^{24}$ As a medium of enlightenment, the public realm had the potential to emancipate individuals from tutelage and, as an institution of political action, had the potential to balance the ruling

\footnotetext{
${ }^{22}$ Kant, ibid., p. 31.

${ }^{23}$ Habermas, The Structural Transformation of the Public Sphere, p. 106.

${ }^{24}$ Calhoun, "Civil Society and the Public Sphere," p. 273.
} 
authorities' political power. In this respect, Kant's ideal of the public sphere, along with the reality of the bourgeois public sphere in the eighteenth century, has been celebrated in contemporary political thought by both Arendt and Habermas. They both emphasize the transformations in this supposedly ideal eighteenth-century public sphere along the path from the nineteenth to the twentieth century. Before going into more detail about how Arendt and Habermas interpreted these degenerations in the public sphere, I shall first focus on how Arendt and Habermas problematize the public sphere.

Following Kant's 'man of the world,' who obtains knowledge of the world and reflects on it within the public sphere, Arendt emphasizes the world-creating potential of the public sphere. For Arendt, the term 'public' has two interrelated meanings: "[i]t means, first, that everything that appears in public can be seen and heard by everybody and has the widest possible publicity ... second, the term 'public' signifies the world itself, in so far as it is common to all of us and distinguished from our privately owned place in it." ${ }^{25}$ Arendt differentiates three human activities which together establish the vita activa: labour, work, and action. Labour refers to the reproductive human activities that are necessary for all, and which humans share with animals. Work is associated with creative processes of designing and making artificial objects, of bringing something new into existence, and which humans share with the gods. Action alone is defined as a human activity that differentiates humans from both other animals and the gods. Among these human activities, action alone corresponds to the political capacities of human beings.

\footnotetext{
${ }^{25}$ Arendt, The Human Condition, p. 50 and 52.
} 
Arendt's problematization of the public sphere should be considered in relation to her distinct political philosophy, which is seen in the concept of action. Action takes place in the public sphere among plural men, each of whom is capable of starting new perspectives and new actions, with the aim of "achieving something more permanent than life itself." ${ }^{26}$ The pre-condition of action (or politics) is freedom, which Arendt defines as freedom from necessity. Her view here seems to differ from Kant's. For Kant, because freedom comes with liberation from tutelage, the public sphere has a mediatory relation to freedom. For Arendt, however, being free from the necessities of life, which she considers as matters of the private sphere, is a pre-condition for participating in action with others in the public sphere. However, there is a reason why Kant does not explicitly define freedom as being liberated from the necessities of life. Kant was talking about the world of men of letters who, in the eighteenth century, comprised educated men who were, to a great extent, free from the necessities of life. For Arendt, this becomes a matter of consideration because, by the nineteenth century, what she sees as the public affairs discussed in the political realm were just an attempt to emancipate the masses from poverty, in other words, mere necessities of life. ${ }^{27}$

For Arendt, this was simultaneously futile and dangerous. It was futile because human beings have always been and will always be subjected to these necessities of life. It was dangerous as far as "necessity invaded the political realm, the only realm where men

\footnotetext{
${ }^{26}$ Arendt, ibid., p. 58

${ }^{27}$ A good place to look for Arendt's discussions on poverty and its irrelevance to true political affairs is Arendt's On Revolution, London: Penguin Books, 2006 [1963].
} 
can be truly free" ${ }^{28}$ because, when necessities of life become the subject of politics, political activity deviates from its world-building capacities, which concern "not so much ourselves and our own time on earth as our 'successor', and 'posterities'."29 Keeping up with the necessities of life, in other words the labour activity itself, inherently carries an authoritarian aspect; it does not let people act freely.

Arendt defines two interrelated causes behind this invasion of the political realm by the necessities of life. First is industrialization, although she does not describe this as a capitalist mode of production. Arendt famously refers to this period as "the rise of the social." What appears to be the public sphere was replaced by a huge private sphere that turns the nation into one big family and finds its political form in the nation-state. ${ }^{30}$ Following the ideal of the Ancients, Arendt argues that, for the ancient Greeks, politics was never for the sake of life as it is in modern societies; it was rather household life that existed for the sake of the "good life" in the polis. She shows that

society, on all its levels, excludes the possibility of action, which formerly was excluded from the household. Instead, society expects from each of its members a certain kind of behavior, imposing innumerable and various rules, all of which tend to 'normalize' its members, to make them behave, to exclude spontaneous action or outstanding achievement. ${ }^{31}$

\footnotetext{
${ }^{28}$ Arendt, On Revolution, p. 104.

${ }^{29}$ See Arendt, On Revolution, pp. 166-167.

${ }^{30}$ Arendt, The Human Condition, p. 28.

${ }^{31}$ Arendt, ibid., p. 40.
} 
Therefore, with labour taking centre stage in modern politics, the table that should stand among the people to provide a venue for their common interests has vanished.

The second motive that Arendt sees behind the withdrawal of the public sphere is more related to the nature of 'action' as she defines it. Arendt describes a threefold frustration of action: "the unpredictability of its outcome, the irreversibility of the process, and the anonymity of its authors." ${ }^{32}$ Thus, the great temptation in modern societies has always been to find a substitute for action to make the realm of human affairs predictable, controllable and accountable, leading in modern times to a preference for administration by technicians rather than government by collective political action. Arendt claims that this temptation to idealize political life in the polis as a human artifact, as a fabrication, began with Plato, who turned his back on action in favor of contemplation. Furthermore, a 'new political science' did not emerge in the 'new world' ushered in by eighteenth-century revolutions, though Tocqueville claimed that "[a] new science of politics is needed for a new world." ${ }^{33}$ Instead, Arendt claims, the new philosophy for new times found its meaning in Hegel's philosophy of history-with everything regarding the political being transformed into a philosophy of history. This new philosophy, she argues, consists in "describing and understanding the whole realm of human action, not in terms of the actor and the agent, but from the standpoint of the spectator who watches a spectacle." ${ }^{34}$ When these two tendencies - the idea of political life as a fabrication and the transformation of

\footnotetext{
${ }^{32}$ Arendt, ibid., p. 220

${ }^{33}$ Tocqueville, cited in Arendt, On Revolution, p. 42, endnote 37.

${ }^{34}$ Arendt, On Revolution, p. 42-43.
} 
the political into a philosophy of history_-juxtaposed, we face the dangerous talk of 'Man' making his own history. Such a view, for Arendt, simultaneously undermines pluralityas 'men,' not 'Man,' live and inhabit the world - and the unpredictability of political action - as making corresponds to work activity, the result of which is always projected even before the activity begins. It therefore attempts to replace the world of action with the society of necessities, or, better still, inhibit it entirely.

Arendt describes how the public sphere has degenerated in modern societies where "through society it is the life process itself which in one form or another has been channelled into the public realm." "35 A parallel view appears in Habermas's concept of the "colonization of the life-world." I will discuss Habermas's separation between the lifeworld and the system below. However, I should note that, although Arendt and Habermas share similar viewpoints in terms of the ideal public sphere, they differ in terms of the political theory tradition they rely on. While Arendt follows the Aristotelian tradition, though she criticizes the form Aristotelian thought took in the age of Enlightenment, Habermas's theory draws on Kantian, Marxian, and Weberian traditions. While Arendt criticizes the way speech (in the sense of rhetoric) replaces action in the public sphere, Habermas points out the unrealized potential of the public sphere as a category of bourgeois society, celebrates the emancipatory potential of rational-critical communication in the public sphere, criticizes the takeover of the public sphere by capitalist production, and relies heavily on constitutional institutions as guarantors of the public sphere.

\footnotetext{
${ }^{35}$ Arendt, The Human Condition, p. 45.
} 
I next briefly outline Habermas's theoretical framework developed in his two volumes of The Theory of Communicative Action. Although he wrote The Structural Transformation of the Public Sphere before publishing these two volumes, understanding the categories he developed in the latter helps contextualize his conception of the public sphere in the former. ${ }^{36}$ The framework is based on two related classifications. While one of them refers to actual social practices and activities, the other refers to the contexts of those activities. In the first category, he includes the 'symbolic reproduction' and 'material reproduction' of societies. In the second category, he distinguishes between 'socially integrated' and 'system integrated' action contexts. While symbolic reproduction takes place in the socially integrated context, the material reproduction of the society takes place in the system-integrated action context. Following these categorizations, Habermas develops the fundamental distinction in his theory, between the life-world and the system. The life-world is defined by symbolic reproduction in a socially integrated context. Habermas situates the private and public spheres within this life world. Accordingly, the private sphere in the life-world comprises the nuclear family, within which norms and values are reproduced by reference to a conventional, pre-reflective, taken-for-granted consensus about ends. The public sphere in the life-world, on the other hand, encompasses political participation and debate/opinion formation as consequences of an explicit, reflective, achieved consensus, which is reached by unconstrained discussion under

\footnotetext{
${ }^{36}$ It can be claimed that Habermas already had a similar schema in mind while writing The Structural Transformation. This is evident in the table he drew to demonstrate how he separates the private and public spheres from each other in The Structural Transformation of the Public Sphere, p. 30. The tables he drew in The Theory of Communicative Action seem expand on this by filling in the blanks in the basic chart.
} 
expected conditions of freedom, equality, and fairness. While consensus in the private sphere of the life-world is rooted in pre-critical internalization of socialization and cultural traditions, consensus in the public sphere of the life-world appears as a result of deliberative action. Together, these two constitute the progressive symbolic continuity of the social. Within the system, which is defined by material reproduction of the social in the systemintegrated context, Habermas identifies another form of the private and public spheres. The private sphere of the system refers to the market, in which all human activities are realized in order to meet needs derived from individual interests, utility maximization, and monetary and power relations. On the other hand, the public sphere of the systemintegrated action implies the administrative system, i.e., the state. ${ }^{37}$

In this schema, the public sphere Habermas defines in The Structural Transformation can be situated in the life-world. Habermas depicts the public sphere as "a sphere between civil society and the state, in which critical public discussion of matters of general interest was institutionally guaranteed." 38 The guiding question of Habermas's inquiry into the public sphere is "to what extent can the wills or opinions guiding political action be formed on the basis of rational-critical discourse?"39 As mentioned earlier,

\footnotetext{
${ }^{37}$ For the detailed analysis of Habermas's distinction between the system and the life-world, see Habermas, The Theory of Communicative Action Volume One: Reason and the Rationalization of Society, Thomas McCarthy (trans.), Boston: Beacon Press, 1984 [1981]; Nancy Fraser, "What is Critical About Critical Theory: The Case of Habermas and Gender," in Feminism as Critique, S. Benhabib and D. Cornell (ed.), Cambridge: Polity Press, 1987; Fraser, "Rethinking the Public Sphere: A Contribution to the Critique of Actually Existing Democracy," in Craig Calhoun (ed.), Habermas and the Public Sphere, Cambridge and London: The MIT Press, 1992; John B. Thompson, "Rationality and Social Rationalisation: An Assessment of Habermas' Theory of Communicative Action," Sociology 17:2, 1983, 278-294.

${ }^{38}$ Habermas, The Structural Transformation of the Public Sphere, p. xi.

${ }^{39}$ Calhoun, "Civil Society and the Public Sphere", p. 273.
} 
Habermas searches for the emergence of such a public in the eighteenth century. Before this, there was the representative publicness of feudal powers, the Church, the prince, and the nobility. However, they were then "disintegrated in a process of polarization; in the end they split into private elements, on the one hand and public ones, on the other." ${ }^{" 40}$ In this line of argument, Habermas famously defines the bourgeois public sphere as

the sphere of private people come together as a public; they soon claimed the public sphere regulated from above against the public authorities themselves, to engage them in a debate over the general rules governing relations in the basically privatized but publicly relevant sphere of commodity exchange and social labor. ${ }^{41}$

For Habermas, England provides the model of the development of the public sphere. He highlights three developments there at the end of the seventeenth century: (1) the foundation of the Bank of England (in 1694), which signaled a new stage in the development of capitalism; (2) the elimination of the institution of censorship (in 1695), which made the press an instrument through which rational-critical arguments could be brought before the new public; (3) the establishment of the first cabinet government (active between 1695 and 1698), which enabled the establishment of the public as an organ of the state. ${ }^{42}$ Meanwhile, coffee-houses, which were considered seedbeds of political unrest, were mushrooming: London had 3,000 coffee houses by the first decade of the eighteenth century, each with its group of regular goers, while journals published in this period were

\footnotetext{
${ }^{40}$ Habermas, The Structural Transformation of the Public Sphere, p. 11.

${ }^{41}$ Habermas, ibid., p. 27.

${ }^{42}$ Habermas, ibid., pp. 58-59
} 
often based in particular coffee houses. It is also in this period that the press established itself as a genuinely critical organ of a public engaged in critical political debate: as the fourth estate. ${ }^{43}$ A new sociability thus emerged in coffee-houses, saloons and other places where private people came together to discuss publicly relevant issues through public use of their reason. For Habermas, this represents the ideal version of the public sphere.

In the nineteenth century, however, the growth of a market economy led to the degeneration of the bourgeois public sphere, according to Habermas. He explains the simultaneous 'societalization' of the state with increasing 'stateification' of society as follows:

state intervention in the sphere of society found its counterpart in the transfer of public functions to private corporate bodies. Likewise, the opposite process of a substitution of state authority by the power of society was connected to the extension of public authority over sectors of the private realm. ${ }^{44}$

As Arendt does, Habermas here defines the problem as the rise of the social. The public sphere in the world of letters, he claims, "had the kind of 'political' character by virtue of which it was removed from the sphere of social reproduction." 45 Since the middle of the nineteenth century, it has become more and more difficult to apply the distinction between public and private to the emerging social sphere. The rational-critical discussion of the

\footnotetext{
${ }^{43}$ Habermas, ibid., pp. 59-60; Calhoun, "Introduction: Habermas and the Public Sphere”, p. 12.

${ }^{44}$ Habermas, ibid., p. 142.

${ }^{45}$ Habermas, ibid., p. 160.
} 
public sphere, Habermas insists, has been replaced by a private world of culture consumption.

There are obviously various and opposed interpretations of Habermas's conception of the public sphere. ${ }^{46}$ It is my contention that Habermas's idealization of the bourgeois public sphere is problematic as it relies heavily on the pre-conditions of a bourgeois culture. In particular, to me, it is not possible that the bourgeois public sphere as a sphere of rational-critical debate encompassing the whole society can work well as defined back in the eighteenth century if certain reforms are pursued in advanced capitalist societies. Hans Verstraeten notes that, in Habermas's conceptualization of the public sphere, "the citizen is construed as a mere 'consumer' of the public sphere, whereas the public sphere can only come into being if the citizen is allowed to act as its 'producer' as well." ${ }^{47}$ I argue that considering citizens as producers of the public sphere requires a sociological point of view that, following Arendt, Habermas rejects for the sake of defining the 'political' as a distinct action rather than social reproduction. In the next section, I look more closely at criticisms of Habermas's arguments.

\footnotetext{
${ }^{46}$ For more recent formulations of Habermasian public sphere theories see Richard J. Bernstein, "The Normative Core of the Public Sphere," Political Theory 40:6, 2012, pp. 767-778; and Lincoln Dahlberg, "The Habermasian Public Sphere: Taking Difference Seriously?" Theory and Society 34:2, 2005, pp. 111-136.

${ }^{47}$ Hans Verstraeten, "The Media and the Transformation of the Public Sphere: A Contribution for a Critical Political Economy of the Public Sphere," European Journal of Communication 11(3), 347-370, p. 350.
} 


\section{A Critique of the Bourgeois Public Sphere from the Perspective of the Social}

Probably the first critique came from Max Horkheimer and Theodor W. Adorno, to whom Habermas submitted the text as his thesis for the post-doctoral qualification required of German professors. They thought that the book was both "insufficiently critical of the illusions and dangerous tendencies of an Enlightenment conception of democratic public life, especially in mass society, and too radical in its politically focused call for an attempt to go beyond liberal constitutional protections in pursuits of truer democracy." 48 Another important line of criticism highlighted Habermas's focus on the bourgeois public sphere while ignoring non-bourgeois public life. Negt and Kluge, for example, responded with an account of the proletarian public sphere while Nancy Fraser emphasized the significance of "subaltern counter-publics," including aspects of race, gender, and class. Michael Warner, on the other hand, drew attention to the dangers of indicating an indefinite public as the public sphere. In this part, I mainly explore Negt and Kluge's conception of public spheres as based on their critique of Habermas to provide an account of the public sphere with a view to the social—although this was not their intention.

Negt and Kluge challenge Habermas's description of the public sphere in their long-ignored book Public Sphere and Experience (1972). While they give the concept of the public sphere its due in social theory by defending it as a still-important conceptual tool, contrary to Habermas, they reject the public sphere's purity. Although, as Frederic Jameson argues, their attempt seems unfinished in terms of defining what the proletarian

\footnotetext{
${ }^{48}$ Calhoun, "Introduction: Habermas and the Public Sphere", p. 4.
} 
public sphere might look like, ${ }^{49}$ their approach provides persuasive tools to understand what is missing in the narratives of the bourgeois public sphere and how modern thought has managed to progress despite these missing parts.

Following Knodler-Bunte, ${ }^{50}$ one can mention three main points where Negt and Kluge's approach is different from that of Habermas. First, Habermas focuses his analysis on the bourgeois public sphere. For him, the proletarian public sphere has been an oppressed part of the bourgeois public sphere since the beginning. In contrast, Negt and Kluge talk about the mutual existence of the bourgeois and proletarian public spheres, thereby making it possible to see the emergence of different publics according to structural transformations in the mode of production. Second, Habermas's theory tends to ignore contradictions between the ideal of the public sphere and the way its historical reality has manifested itself. Negt and Kluge, however, consider a variety of public spheres, which enables them to explore these contradictions by excluding the ahistorical discourses of the public so as to provide the grounds for a historical materialist analysis of public spheres.

Third, and related to the second point, Habermas pays too much attention to the normative value of the bourgeois public sphere, which results in his political endeavour to reform the procedures of the public sphere. Negt and Kluge's analysis, on the other hand, starts by acknowledging the varieties of public sphere and human experience that are firmly

\footnotetext{
49 See Frederich Jameson, “On Negt and Kluge," October vol. 46, Autumn 1988, p. 157. He observes that "we set out, Negt and Kluge tell us, to project a proletarian public sphere and found ourselves reduced writing a critique of the limits of the bourgeois public sphere."

${ }^{50}$ Eberhard Knodler-Bunte, Sara Lennox and Frank Lennox, "The Proletarian Public Sphere and Political Organization: An Analysis of Oskar Negt and Alexander Kluge's Public Sphere and Experience," New German Critique, No. 4 (Winter, 1975).
} 
tied to societal practices in everyday life. The political consequence of their analysis is that one could (and should) search for the means to reveal the revolutionary potentialities of the proletariat by (re-)defining the existing public sphere and claiming the new public spheres on the basis of the un-determined, unforeseeable experiences and interests of the workingclass. Their analysis thus pre-empts a reductionist reading of the public sphere, which would limit it to state institutions and procedures, while permitting one to see the opposing potentials of non-bourgeois experience and interests in forming new publics. ${ }^{51}$

The terms 'experience' and 'interests' are central to Negt and Kluge's framework as they delineate the public sphere as the organization of collective experiences rather than the institutions and procedures that we have come to call public. Experience (Erfahrung) here refers, in its Hegelian meaning, to 'mediated experience,' understood through a dialectical process. They claim that 'un-mediated experiences' gain a mediated, transforming character within plurality, which is organized in the context of the proletarian public sphere. ${ }^{52}$ Their main concern here is the ways in which, the means by which, the mechanisms through which, for the benefit of whom the social aspect of experience has been constructed..$^{53}$ In this sense, they distinguish different publics on the basis of the material conditions of experiences and interests.

${ }^{51}$ Ibid., pp. 54-55.

${ }^{52}$ Here, it can be argued that Negt and Kluge, following Lukács, prioritize the proletarian life context in extracting real life experiences. They claim that plurality, collective interest and experience are only possible in the proletarian public sphere because, in the bourgeois life context, one can only mention individual interests, a multitude that does not necessarily form a collective experience. See Lukács, History and Class Consciousness: Studies in Marxist Dialectics, Rodney Livingstone (trans.), Massachusetts, Cambridge: The MIT Press, 1971.

${ }^{53}$ Miriam Hansen, "Foreword," in Negt and Kluge, Public Sphere and Experience, p. x. 
For Negt and Kluge, the public sphere is "a general horizon of experience in which everything that is relevant for all members of society is integrated." 54 This means that it possesses no use-value unless the social experiences of the majority of society can organize within it. The public sphere in bourgeois imagination under capitalist production-i.e. parliament, party politics, mainstream media, clubs, and societies — seems to have no direct relation to the social experience of the proletariat. In other words, due to the overall workings of the capitalist production process, "the historical production of experience, organization, and public sphere disappears into its resulting product, the public sphere that determines the present." ${ }^{25}$ It is this public sphere as an end product that is presented as the field of political action in modern capitalist societies. Habermas, and to a certain extent Arendt, fail to take into account this reified content of the bourgeois public sphere. They do not recognize that the reification of the public sphere-in other words, forgetting its production process and seeing it as an end product—begins with the detachment of the social from the political, of the private from the public, and of civil society from the state. Instead, they blame the rise of the consumer society and free market economy since the nineteenth century for colonizing (or, better, commodifying) the public sphere. ${ }^{56}$ However, they fail to see that the very definition of the bourgeois public sphere has a commoditylike character from the beginning by virtue of which it became detached from the process of social production. That is, as a concept—and as a significant part of liberal discourse-

\footnotetext{
${ }^{54}$ Negt and Kluge, ibid., p. 2.

${ }^{55}$ Ibid., p. 4, footnote 8.

${ }^{56}$ See Habermas, The Structural Transformation of the Public Sphere, p. 141 and Arendt, The Human Condition, pp. 56-57.
} 
it is alienated from the social forces that produced it, and in turn fetishized as the sole realm to be involved in politics. Habermas clearly contributes to this alienated and alienating definition in his admiration for the eighteenth-century public, defined in an Arendtian manner:

The rational critical debate of private people in the salons, clubs, and reading societies was not directly subject to the cycle of production and consumption, that is, to the dictates of life's necessities. Even in its merely literary form it possessed instead a "political" character in the Greek sense of being emancipated from the constraints of survival requirements. ${ }^{57}$

When Habermas's idealized public sphere of eighteenth-century England is recalled with Negt and Kluge's categories in mind, it can be observed that what Habermas defines as the ideal public sphere did not represent the interests and experiences of the majority. His definition rather refers to the organized experiences and interests of a small exclusionary group of propertied men who defined moral norms, which later became political norms, for their own 'Society' (as in French Société) and for society at large. However, this group was not as detached from the process of social reproduction as Habermas assumes in the above quote. Especially in the eighteenth century, a central theme of these so-called rational-critical debates in the Gentlemen's Société was the state of the poor because men of letters in the eighteenth century were the carriers of the re-formation of the social and political. The rising concern of the ruling elite, therefore, was the

\footnotetext{
${ }^{57}$ Habermas, ibid., p. 160.
} 
population as the signifier of the nation instead of the territorial existence of the state. As Joad Raymond stresses in opposition to Habermas, “[e]xchange in coffee-house debate is presented in contemporary texts as a dystopian phenomenon, suggesting that such spaces were in reality permeated by a consciousness of social difference and social conflict ... debate was neither open nor freely rational." 58

Habermas defines these societies as 'political' mainly because of their capacity to affect England's policy-making, or rather law-making processes. However, what Habermas seems to miss here is that these law-making processes (and hence the critical discussions around them) primarily addressed two problems: "[how] to legitimate the rights of property $\ldots$ and [how] to police the labouring poor into the habituation of their stations." 59 As Corrigan and Sayer clearly demonstrate, the difference of the eighteenthcentury English state from contemporary European absolutism was its permissiveness, which allowed men of different kinds of property status participate in state activities. ${ }^{60}$ What Habermas admires here was in fact nothing more than "the construction of the typical state/economy relations of bourgeois societies, whereby the former secures the conditions in which the latter can 'freely' operate, through the inflection of older forms." ${ }^{61}$ If anything, discussions in the public sphere during this period (regardless of the form of

\footnotetext{
${ }^{58}$ Joad Raymond, "Perfect Speech: The Public Sphere and Communication in Seventeenth-Century England" in Alex Benchimol and Willy Malley (eds.), Spheres of Influence: Intellectual and Cultural Publics from Shakespeare to Habermas, London: Peter Long, 2007, p. 46.

59 Philip Corrigan and Derek Sayer, The Great Arch: English State Formation as Cultural Revolution, Oxford and New York: Blackwell, 1985, p. 96.

${ }^{60}$ Ibid., p. 91.

${ }^{61}$ Ibid., p. 92.
} 
communication used) helped construct a moral rhetoric that "linked the facts of commerce to the promise of liberty." ${ }^{62}$ And it was exactly through this rhetoric that the historic bloc of the public was formed in the nineteenth century. Habermas's analytical framework does not permit us to understand the ways in which this historic bloc was constructed in the first place, it is difficult to delve into the relations between diverse, multi-layered publics that were formed into the public in the discursive field of Western thought. Despite their lack of social history analysis, Negt and Kluge's depiction of the public sphere as an analytical category is more persuasive. Using the tools that they offer expands our analysis of how publics were formed and operated in eighteenth and nineteenth-century England. Indeed, it becomes clear that it was not only those coffee house discussions that influenced parliamentary decisions, it was also the power of the streets, where the working and nonworking poor were mobilized, that affected the discussions of the bourgeoisie, whose main focus became fabricating a certain public order.

With reference to different fields of experience, Negt and Kluge outline three public spheres: the classical bourgeois public sphere, the industrial public spheres of production, and the proletarian public sphere. These different spheres are not separated from each other by their boundaries as they usually share the same physical/intellectual space and relate to each other by encompassing and/or creating the antithesis of another (i.e. the realm of the other) within themselves. ${ }^{63}$ Although the classical bourgeois public sphere initially looks like the bourgeoisie's sphere of domination, in the context of a dialectical relationship it

\footnotetext{
${ }^{62}$ Ibid., p. 106.

${ }^{63}$ Ibid., p. 57.
} 
encompasses both the industrial public spheres of production and the proletarian publics. On the other hand, the contradictions emanating from this inclusion of the opponent find their meaning in an exclusionary mechanism. The classical bourgeois public sphere, for example, has no readily attainable use-value for the proletariat, the great majority of society as they can barely find a space within this sphere to express the experiences and interests emanating from their everyday life needs.

The bourgeois public sphere, in this sense, has been constructed on the particular interests of the ruling classes that are not necessarily social and not in the interest of the entire society. In bourgeois imagination, everything is for society (as in the discourse of human rights), yet real society does not exist or, more precisely, it is always in the making by the ruling classes. The question then was how to make the private interests of the bourgeoisie look like public interests. To do so required a threefold endeavour towards three targets: regulation of the state and its institutions, freeing the market, and confining labourers and their life context within the domestic space. The crucial aim here concerned the oppression of the poor. These targets of the eighteenth-century bourgeois public sphere ideal — as the organized form of bourgeois experience — and the motives beneath these targets were founded in the words of Adam Smith:

Laws and governments may be considered in this and indeed in every case as a combination of the rich to oppress the poor and preserve to themselves the inequality of the goods which would otherwise be soon destroyed by the attacks of 
the poor. Who if not hindered by the government would soon reduce the others to an equality with themselves by open violence. ${ }^{64}$

These interventions into the life context of the poor to prevent them from destabilizing the bourgeois life context involved two main projects: privatization-in terms of both domestication and marketization-and re-definition-in terms of both (im)moralization and criminalization — of the public manners and spaces of the proletariat. Privatization operates through attempts to reduce the public visibility of proletarian men and women by stipulating proper public attitudes. I refer to this project as the 'domestication of proletarian manners' because, through these instructions and inscriptions, the proletarian manners that had been transmitted from one generation to another were confined to the private lives of the proletariat whereas middle class manners attained public visibility. In other words, the social experiences that people produced in everyday life were prevented from being publicized by the distinction between public and private. In this sense, the public-private distinction operated as a strategy to pacify publicity based on shared proletarian experience.

The project to privatize proletarian manners has another aspect to it: privatization through marketization of once commonly enjoyed spaces. I refer to this project as 'marketization of the proletarian fields,' which puts control of public space into private hands. The very existence of these private hands (and of course the public sphere) depends on other private functions that operate in these spaces. At this point, David Harvey's

\footnotetext{
${ }^{64}$ Adam Smith, Lectures on Jurisprudence, R.L. Meek, D.D. Raphael, and P.G. Stein (eds.), Indianapolis: Liberty Classics, 1982 [1760s], iv. 23.
} 
remark on nineteenth-century boulevards is important: "The validation of the new public spaces (the splendor the boulevards displayed) was heavily dependent upon the control of private functions and activities that abutted upon it." 65

The re-definition of proletarian interests, which went hand in hand with domestication and marketization, on the other hand, involved enacting new rights to property as well as moral regulations regarding public visibility and hence the criminalization of the customary rights and morals of the poor. Both projects, privatization and re-definition, targeted the proletarian life context, employing tactics of coercion and consent, and a discourse of criminalization. The agents of these projects therefore embraced the notion of police as a central theme, making it a new project to consolidate order in the public. Here, it should be noted that the three public spheres defined abovethe bourgeois public sphere, the industrialized public spheres of production, and the proletarian public sphere - cannot be separated from each other is because they involve overlapping agents and targets. The bourgeoisie's attempt to discipline the proletariat creates a field where all three public spheres intersect. For example, after consensus was reached in the bourgeois public sphere, Victorian music halls, which were previously commonly enjoyed public spaces, were privatized, licensed, and subjected to surveillance by police forces. This example alone can be read as an intersection linking the three dominant public spheres. ${ }^{66}$

\footnotetext{
${ }^{65}$ David Harvey, "The Political Economy of Public Space" in Setha Low and Neil Smith (eds.), The Politics of Public Space (New York and London: Routledge, 2006), p. 21.

${ }^{66}$ For a detailed history of the Victorian music halls, see Peter Bailey, "Rational Recreation and the Entertainment Industry: the Case of the Victorian Music Halls" in Peter Bailey, Leisure and
} 
This talk of a public sphere that excluded the experiences of a great majority of the population through privatization and re-definition of interests caused working class people largely to lose their interest in the bourgeois public sphere, which further alienated them from the legitimate sphere of political action. ${ }^{67}$ Returning to Adorno and Horkheimer's critique of Habermas's idealized definition of the public sphere, it is clear that Habermas misses this dangerous tendency of liberal-democratic public life in that he fails to recognize that the form in which the bourgeois public sphere manifests itself overlaps with the social structure of capitalist production, and hence its institutions operate accordingly: capital is private property, hence it must remain in the private sphere; however, the control of capital is public in that raw materials, the means of production, money, and workers are actually parts of the public sphere. ${ }^{68}$

This, in turn, makes it difficult for the proletariat to comprehend their own place within the totality. Once workers one way or another enter the bourgeois public sphere, once they accidentally obtain a position in the public sector, they face a dilemma: the public sphere is for the use of private interest. This is exemplified by the first hired parish constables in the eighteenth century. When householders in the parishes started to hire others - the poor in this case - to do the supervising work for them, "the parish's poorest

Class in Victorian England: Rational Recreation and the Contest for Control, 1830-1885. He stresses that "by the late Victorian period it could be claimed that the music hall had been assimilated to the cultural apparatus of a capitalist society ... In a sense, big business had succeeded where the social reformers of recreation had failed" (p. 168).

${ }^{67}$ Although the Chartist movement can be depicted as representing the working classes' claim on the bourgeois public sphere, within the framework outlined here, I will consider it under the topic of the proletarian public sphere in the fourth section.

${ }^{68}$ Ferruccio Rossi-Landi, cited in Negt and Kluge, Public Sphere and Experience, p. 4. 
and most unfit were often the parish constables," many of whom "were notorious for bribetaking and collaboration with known criminals." 69 The emergence of modern police forces in 1829, gave England's poor their first chance to obtain a state office. Unsurprisingly, therefore, the Metropolitan Police Acts of 1829 and 1839 stipulated the expected conduct, manners, and attitudes of police officers, such as not drinking while on duty, which exemplifies how the bourgeoisie tried to prevent the poor from misusing their position. ${ }^{70}$ As George S. Rigakos clearly states, there has been in this sense no difference between public and private police since then as the supervision of police officers has always been important in policing institutions. ${ }^{71}$ The overlaps and transitions between the two spheres prove the point that the bourgeois public sphere concerns the private interests of the bourgeoisie while trying to orchestrate the proletariat so as to make them best serve these interests.

The structure of the bourgeois public sphere paves the way for a kind of politics that is limited to institutions and procedures while relying on the fetishism of parliamentary politics. The proletariat are now faced by a reified and estranged public sphere, and told to politicize, be represented, and hence recognized within the borders of this sphere. How they are supposed to act in it is determined by laws so they have to adjust to a new language,

\footnotetext{
${ }^{69}$ J. L. Lyman, "The Metropolitan Police Act of 1829: An Analysis of Certain Events Influencing the Passage and Character of the Metropolitan Police Act in England", Police Science 55, 1964, p. 141.

${ }^{70}$ See the Metropolitan Police Act of 1829 and of 1839. Most of the act deals with defining the proper conduct and manners of the officers.

${ }^{71}$ George S. Rigakos, The New Parapolice: Risk Markets and Commodified Social Control, Toronto: University of Toronto Press, 2002, see pp. 9-22.
} 
attitudes, apparel and so on in order to be visible in this sphere. The bourgeois manners required in the public sphere also presume a specific education, requiring a new vocabulary and body language. As Pierre Bourdieu explains, the symbolic power congealed in the structuration of public spaces privileges an exclusionary mechanism. ${ }^{72}$ Yet, this exclusion creates a kind of attachment to the estranged sphere in that the workers become unquestioningly attached to it despite being unable to comprehend its new language; if they cannot attach to it they have to be confined to their private sphere at worst or create alternate publics that reflect their proletarian manners and interests at best. That is, if they cannot find their own language to voice their own interests, they are condemned to lose their own life experiences within the stereotypical lifestyle presented to them. Thus, it is no accident that liberal democracies experience crises of legitimation and representationas Habermas would put it.

Negt and Kluge acknowledge that the term public is an invention of the revolutionary bourgeoisie — so much so that it is indeed their most revolutionary cry. They argue that the revolutionary bourgeoisie proposed this concept by benefiting from the social empathy of the concept of public opinion with the aim of unifying society, i.e. making society an entire 'thing,' a fabrication, a commodity. It is my contention that the commodity character of the bourgeois public sphere has several features that help it exclude the kind of socialization built on labour-driven experience. First, once it is fabricated, the production process of the public sphere and its producers are forgotten. Second, once its

\footnotetext{
${ }^{72}$ Pierre Bourdieu, “Social Space and Symbolic Power," Sociological Theory 7:1, Spring 1989, pp. $14-25$.
} 
production process is forgotten, it becomes an imagination, an ideal of bourgeois ideology, or, in Marxian terms, an estranged thing. Third, since it is estranged from its producers, it stands as something alien to them, something bigger and more valuable than the producers themselves. Fourth, as it is nothing more than an imagination, it is easier to fetishize it. Fifth, it has an exchange value that is not measured with money but with other credentials that can be purchased with money, such as higher education. Sixth, one has to buy a place in the public sphere (that is to say, be represented in it) and consume it in order to exist in bourgeois society. Seventh, the expense of buying a place requires one to leave one's own life experience, confine it in the private sphere, and comply with what is presented to one in public because the exchange value of buying a place in the public sphere does not value one's being as a producer of the public sphere. Finally, once consumed as a commodity, the public sphere provides no benefit to the interests of the majority.

Although the bourgeois public sphere provides a space for rights-based political movements, as Marx and Engels argue, these political movements are, to a large extent, the "movements of minorities, or in the interest of minorities." 73 As they note, "in all these battles [the bourgeoisie] sees itself compelled to appeal to the proletariat, to ask for its help, and thus, to drag it into the political arena." ${ }^{74}$ As long as the producers of the public sphere and the publicly relevant issues are left out, observing debates around the new constitution means nothing more than watching a soccer game or a soap opera for the majority. And

\footnotetext{
${ }^{73}$ Karl Marx and Friedrich Engels, Manifesto of the Communist Party, Samuel Moore (trans.), Moscow: Progress Publishers, 1977, p. 47.

${ }^{74}$ Ibid., p. 46.
} 
soap operas and soccer games are involved in the lives of the majority no less than the constitution itself since, for them, reality has lost its meaning in the bourgeois public sphere. This creates a community, as Sennett emphasizes, "which has a collective personality, a collective personality generated by a common fantasy." 75 Absurdity becomes reality. The task therefore should be to uncover the diverse experiences and actions that produce multiple public spheres in order to overthrow the public sphere as an ideological template and reveal its revolutionary potential.

\section{In between the Conspicuous Charm and the Discreet Distaste of the Bourgeoisie}

As shown in the first part, Habermas argued that organized capitalism from the nineteenth century onwards gradually dissolved the relationship between the public and private spheres, leading eventually to a breakdown of the public sphere whereby it lost its political significance. ${ }^{76}$ However, Habermas fails in theorizing — or, better, fitting into his theorization of the public sphere-how organized capitalism and the publicly-open spaces emanating from it could differ from the public use of reason. Calhoun's evaluation of this point is important:

Structural Transformation does not treat the 'classical' bourgeois public sphere and the postransformation public sphere of 'organized' or 'late' capitalism symmetrically. Habermas tends to judge the eighteenth century by Locke and Kant,

\footnotetext{
${ }^{75}$ Richard Sennett, The Fall of Public Man, p. 223.

${ }^{76}$ Habermas, The Structural Transformation of the Public Sphere, p. 140.
} 
the nineteenth century by Marx and Mill, and the twentieth century by the typical suburban television viewer. ${ }^{77}$

What is suggestive in Calhoun's formulation is his assessment that Habermas fails to provide the historico-theoretical background for his interpretation of the twentieth-century public sphere. However, this assessment is still incomplete because what both Habermas and Calhoun refer to by the twentieth-century public sphere is a public sphere dominated by market relations, which is not specifically a twentieth-century phenomenon. Rather, public opinion in shops and manufactories was a point of interest in eighteenth-century England: "there is often found more real public wisdom and sagacity in shops and manufactories than in the cabinets of princes in countries where none dares to have an opinion until he comes into them."78 Thus, in order to complete Calhoun's evaluation, one also needs to question Habermas's treatment of the eighteenth and nineteenth-century public spheres and his silence about the emerging spheres of the free market during this time.

In this respect, Negt and Kluge's emphasis on the new public sphere of twentiethcentury industrial production can be read as supplementing Habermas's inadequate reading of the twentieth century's market-dominated public sphere. As such profit-driven sectors as the sophisticated world of media corporations, marketing and human relations are always in the making, and as they also make up, fabricate and industrialize a public, Negt and Kluge call them the "new public spheres of industrial production." Yet, while

\footnotetext{
${ }^{77}$ Calhoun, "Introduction: Habermas and the Public Sphere," p. 33.

${ }^{78}$ Burke, cited in Habermas, The Structural Transformation of the Public Sphere, p. 94.
} 
acknowledging that these spheres have use value primarily for those in advertising and marketing, Negt and Kluge do not underestimate their public relevance. Moreover, they argue that, within these spheres, we can see more of the everyday life elements of the proletariat. Instead of a mediating public sphere, as in the case of the bourgeois public sphere, the public spheres of industrial production emerge with a demand to reach and influence individuals' private lives; they constitute a basis for the expropriation of the public-private distinction. ${ }^{79}$ The public spheres of industrial production then re-define the private both as a subject of communication and as an object of profit; the commodities themselves behave in these spheres as actors generating networks of relationships among other commodities, people, and themselves. Everyday life elements are taken as raw material and processed for the benefit of capital, in turn transforming the horizon of experience. In this sense, the structure embraces not only the interests of capital but also the interests of the working classes, insofar as they are integrated with capital as consumers. As opposed to the exclusionary character of the traditional bourgeois public sphere, the public spheres of industrial production are characterized by "oscillation between exclusion and intensified corporation." 80

I find Negt and Kluge's vocabulary helpful for understanding the public relevance of spheres controlled by capitalist production and distribution. Nevertheless, I think one needs to expand the life span of the term "new public spheres of industrial production" back to the late eighteenth century, and thus call these domains of interaction 'market-

\footnotetext{
${ }^{79}$ Negt and Kluge, Public Sphere and Experience, p. 35.

${ }^{80}$ Negt and Kluge, ibid., p. 14.
} 
public spheres,' simply because we need this conceptual tool to understand the spheres of industrial production from their beginnings. Space is socially produced as the product of social and political relationships among people. In turn, as Lefebvre argues, space is always "a means of production, it is also a means of control, and hence of domination, of power; yet that, as such, it escapes in part from those who would make use of it." ${ }^{\text {81 }}$ Thus, space is never neutral nor free from the mode of production of material conditions or from power relations. The space that ultimately became both the means and product of capitalist production reveals itself in market-public spheres in a crystalized form.

\section{From Labour to Action: The Whereabouts of the Proletarian Public Sphere}

In this part, I benefit from the distinction Arendt draws between labour and action, but from a different angle that would most likely be disturbing for Arendt herself. Arendt defines action as the sole activity that exclusively belongs to humans whereas other components of vita activa, namely labour activity, are shared with other animals while work activity is shared with gods. ${ }^{82}$ Nevertheless, although I side with Arendt's definition of politics on the basis of action-which in itself makes her understanding of politics an activist politics, as Mary G. Dietz demonstrates ${ }^{83}$ - I instead try to emancipate labour activity from Arendt's limited view and return justice to labour activity in Arendt's definition of the political.

\footnotetext{
${ }^{81}$ Lefebvre, The Production of Space, p. 26.

${ }^{82}$ Arendt, The Human Condition, p. 180.

${ }^{83}$ Mary G. Dietz, "Feminist Receptions of Hannah Arendt" in Feminist Interpretations of Hannah Arendt, Bonnie Honig (ed.), Pennsylvania: The Pennsylvania State University Press, 1995.
} 
Becoming political through labour activity is crucial as, according to Arendt, labour turns out to be the only activity people share together universally. ${ }^{84}$ In addition, labour in capitalist social relations does not only produce the means of subsistence, as Arendt would argue; it also produces material social relations that have capacity for action in an Arendtian sense. As Marx once argued,

[the] mode of production must not be considered simply as being the production of the physical existence of the individuals. Rather it is a definite form of activity of these individuals, a definite form of expressing their life, a definite mode of life on their part. As individuals express their life, so they are. What they are, therefore, coincides with their production, both with what they produce and with how they produce. $^{85}$

In other words, contrary to what Arendt argues, ${ }^{86}$ Marx does not equate labour activity with work activity and both with political action (all used in Arendtian terms). Instead, it is

\footnotetext{
${ }^{84}$ Although Arendt claims that Marx misread the socio-political structure when he gave labour a central role in his analysis, she acknowledges Marx's importance in initiating a revolution in the tradition of Western political thought: "Marx's definition of man as animal laborans stood in conscious opposition to and challenged the traditional definition of man as animal rationale." See Arendt, "Karl Marx and the Tradition of Western Political Thought", Social Research, Vol. 69, No. 2 (Summer 2002), p. 301.

${ }^{85}$ Karl Max and Frederick Engels, The German Ideology, Moscow: Progress Publishers, 1968, pp. 31-32 (emphases are original).

${ }^{86}$ Arendt's main critique of Marx emanates from her misundertanding that Marx does not separate the meanings of labour from work and reduces political activity to a struggle on the basis of labour activity. "Within a completely 'socialized mankind,' whose sole purpose would be the entertaining of the life process - and this is the unfortunately quite unutopian ideal that guides Marx's theories - the distinction between labour and work would have completely disappeared; all work would have become labour because all things would be understood, not in their worldly, objective quality, but as results of living labour power and functions of the life process." Therefore, she argues that, "Marx's original charge against capitalist society was not merely its transformation of all objects into commodities but that 'the labourer behaves toward the product of his labour as to
} 
meaning, culture, aesthetics, and action that productive forces produce and express in their mode of life. Although for a long time, including during Arendt's life time, Marxists have reduced Marx's theory to the production process and searched for possibilities within the labour time and space, Marx's understanding of the labour process does not exclude worker-as-subject, i.e. workers as subjects creating their own lives. As Thompson notes,

[p]roduction, distribution and consumption are not only digging, carrying, and eating, but are also planning, organising and enjoying. Imaginative and intellectual faculties are not confined to a "superstructure" and erected upon a "base" of things (including men-things); they are implicit in the creative act of labour which makes $\operatorname{man} \operatorname{man}^{87}$

What people produce and how they produce is therefore significant for a theoretical imagination of their 'this worldliness,' or, more precisely for the purpose of this thesis, the public sphere they condition. It is the lived experience that brings productive forces together or separates them from each other. To express this in Arendt's words:

To live together in the world means essentially that a world of things is between those who have it in common, as a table is located between those who sit around it; the world, like every in-between, relates and separates men at the same time. ${ }^{88}$

an alien object' - in other words, that the things of the world, once they have been produced by men, are to an extent independent of, 'alien' to, human life." Arendt, The Human Condition, p. 89 and $22 \mathrm{n}$.

${ }^{87}$ E.P. Thompson, “Socialist Humanism,” The New Reasoner 1, 1957, pp. 105-143.

${ }^{88}$ Arendt, The Human Condition, p. 52. 
In other words, the raw material of 'the table' that Arendt uses as a metaphor to define the public sphere can be the lived experience of the proletariat: what unites (and separates) workers.

The bourgeois public sphere, then, cannot have use value for the proletariat unless the experience of workers is organized within it. Otherwise, the existence and/or imagination of a public sphere in which predominantly bourgeois interests and experiences are organized creates an environment and politics that excludes or marginalizes the experience, interests, and exploited existence of working-class people. Workers become the objects of bourgeois politics in the same way they are the objects of bourgeois economics, which alienates them from the kind of bourgeois politics in the same way they are alienated from their own labour. Their right to decision-making about their own mode of life and about the public they helped to create is taken away from them by the bourgeois public and its instruments to be placed instead on the market (through election campaigns) for the proletariat to buy (by voting). As Pierre Bourdieu bluntly puts it, the action of voting does not favour the dominated for at least two reasons:

First, agents do not all possess to the same degree the instruments, especially the cultural capital, necessary to produce what is called a personal opinion... Second, the atomistic and aggregative mode of production dear to the liberal vision favors the dominant, who, because the structures of the social order operate in their favor, can be content with individual strategies (of reproduction), whereas the only chance for the dominated to break out of the dilemma of withdrawal (through abstention) 
and submission is for them to escape the logic of individual choice, for them profoundly alienating. ${ }^{89}$

And this makes it impossible through the means provided by the bourgeois public sphere for the subordinated classes to transform themselves from the objects of struggles to the subjects. Therefore, the question of how social and political change involving proletarian agency can occur requires closer attention to the forms and formations of proletarian public spheres.

According to Negt and Kluge, the existence of experiencing subjects who, no matter to what degree they are alienated and dominated, are still capable of constituting a horizon for general proletarian experience. ${ }^{90}$ With this distinguishing feature, the proletarian context of life constitutes the 'real life bloc,' i.e. the proletarian public sphere. ${ }^{91}$ They lay out three conditions that need to be met for a proletarian public sphere to come into existence: (1) the motivating force of the public sphere should consist of the interests of the productive class; (2) it should be possible to create a medium that will establish links between the interests of producers and society as a whole; (3) the effects of the dividing and deterrent tools of the bourgeois public sphere (such as police forces) should not be very dominant in the formation of a proletarian public sphere. ${ }^{92}$ The proletarian public sphere,

\footnotetext{
${ }^{89}$ Pierre Bourdieu, "The Mystery of the Ministry: From Particular Wills to the General Will," Constellations Volume 11, Number 1, 2004, p. 40.

${ }^{90}$ Negt and Kluge, Public Sphere and Experience, p. 6.

${ }^{91}$ Negt and Kluge, Public Sphere and Experience, p. 57. Although they often refer to the concepts of "real life bloc," "historical bloc" and hegemony, Negt and Kluge do not openly take a Gramscian point of view.

92 Negt and Kluge, Public Sphere and Experience, pp. 91-92.
} 
once organized in this way, actively mediates between social existence and consciousness as it represents a form of interaction that is expressed in such a way that the vital interests of the working class can relate to the totality of society. ${ }^{93}$

According to Negt and Kluge, the empirical working-class public sphere appears in two forms: as an encampment and as a variation of the bourgeois public sphere. If the working class organizes itself successfully within the bourgeois public sphere as a camp then this will decrease the chances to create a proletarian public sphere that presumably encompasses the entire society. If the organization of the proletarian context of life cannot evolve into such a public sphere, this camp, despite its intention to free itself from the bourgeois context, will inescapably re-produce the mechanisms of the bourgeois public sphere by creating its own procedures. That is, it will maintain its existence through practices of exclusion, pseudo-publicity, and the dictatorship of procedural rules. Although Negt and Kluge's definition of the proletarian publics provides a useful terminology, it cannot go beyond some fallacies of classical Marxism, which I will explore in Chapter Five, where I also try to expand the concept's scope and explore its theoretical capacity to explain nineteenth-century class struggles over the political space. Here, however, it should suffice to mention that understanding the proletarian context of life through the concept of the proletarian public sphere is not only useful but also revolutionary in that it creates a counterhegemonic standpoint at the discursive level.

\footnotetext{
${ }^{93}$ Knodler-Bunte, “The Proletarian Public Sphere and Political Organization,” p. 56.
} 


\section{Conclusion}

In this chapter, I have tried to make sense of the concept of the public sphere for an historical understanding of the proletarian context of life. In so doing, I first identified the problems involved in the various definitions of the term in modern Western political thought. I then attempted to re-conceptualize and re-contextualize the term so as to include the diverse publics impinging on and overlapping with each other. In this attempt, I aimed also to re-construct a conceptual tool that has been the subject matter of either merely political or merely social concerns. Since my broader, or even seemingly external, aim is to demonstrate that the spheres of the political and the social cannot be separated from each other, I tried to demonstrate the interconnectedness of the social and the political through the concept of the public sphere.

The primary task of this chapter, in this sense, can be summarized as an attempt to demystify the concept of the public. This term is dangerous, not so much because of misconceptualizations by various theorists, but because of the always existing fictional public that the governing classes have had to address throughout modern history. I therefore found it crucial to ask the following questions: What are the ways in which diverse public spheres have been constructed and re-constructed through discursive and material practices? How do the ideologies and knowledge forms of each public sphere take shape? Who are the historical forces that encounter each other in this shaping and reshaping? What aims, interests, and experiences are revealed by the historical struggle for the public? 
This chapter does not answer all of these questions in detail but leaves them to subsequent chapters. So far, however, I have claimed that the public sphere is historically one of "the most revolutionary cries of the bourgeoisie." Understood as "the private people's public use of reason," the public sphere as a bourgeois category sets the boundaries of social and political action while gradually erasing the traditional publics. The political history of modern capitalism is a history of eliminating diverse publics to assemble the public sphere. This history, however, was not free from its dialectical opposite, that is, the proletarian public sphere so I also argued that the project of the bourgeois public sphere paved the way for the emergence of the proletarian public sphere as its opposite and the market-publics as its supplement. The construction of the bourgeois public sphere turned into a project to consolidate the hegemony of bourgeois politics, ethics, and aesthetics over the non-bourgeoisie. It involved using many technologies, including laws and regulations, the mass media, and the organization of physical space. These technologies were intended to control, tame and discipline those public actors that might offer a challenge to the public, forged with a capitalist spirit. As mentioned earlier, Arendt depicts the threefold frustration of political action: "the unpredictability of its outcome, the irreversibility of the process, and the anonymity of its authors." 94 In modern times, I conclude, the great temptation has always been to find a way to predict, control, and secure the political action of the proletariat by intervening in their life contexts; that is, the proletarian public spheres.

\footnotetext{
${ }^{94}$ Arendt, The Human Condition., p. 220
} 


\section{CHAPTER THREE}

\section{A POLITICAL NARRATIVE OF THE SOCIAL POLICE}

The politician is a weaver...the art of politics is like the art of the weaver...the weaver joins the warp and the weft. The politician will bind the elements together, the good elements formed by education; he will bind together the virtues in their different forms, which are distinct from and sometimes opposed to each other; he will weave and bind together different contrasting temperaments, such as, for example, spirited and moderate men; and he will weave them together thanks to the shuttle of a shared common opinion.

Michel Foucault, Security, Territory, Population

Starting from the mid-seventeenth century in both England and continental Europe, police, along with its sister terms security, crime, surveillance, and control lay at the heart of the search for a new social and political order. The effects of technological advances, geographical discoveries, religious reformations, and scientific inventions on the possible restructuration of states were articulated within the science of police. I therefore argue that the science of police turned out to be the leitmotif of political changes trying to catch up with socio-economic changes or, better, changes in the mode of production, both then and later as capitalism developed into today's neoliberal phase. Such an account of police-as 
opposed to an account concerning police as a regulatory force of urban society-allows a much broader understanding of modern politics. ${ }^{1}$

It is important to understand the relationship between modern politics and the police project of the seventeenth and eighteenth centuries in order to make claims about modern politics. This chapter therefore aims to understand the emergence of the police project of late seventeenth and eighteenth centuries in its definition of modern politics as political economy and the modern nation as the public. In the first part of this chapter, I explore what makes the police project an Enlightenment project. In the second part, drawing on a re-reading of Ancient Greek texts, I look at the re-invention of politics through police science. In this part, I try to show the centrality of the police ideal for the modern art of government. Also, I look at the ways in which early modern police science re-defined politics to embrace political economy as its aim. In the third and final part, I explore the centrality of labour exploitation and primitive accumulation for police science. Overall, the chapter is intended to shed light on the narrowing of the police project down to the modern

\footnotetext{
${ }^{1}$ See for example Sydney L. Harring, "Policing a Class Society: The Expansion of Urban Police in the Late Nineteenth and Early Twentieth Centuries" in David F. Greenberg (ed.) Crime and Capitalism: Readings in Marxist Criminology, Mayfield Publishing Co.: Palo Alto, 1980 and Temple University Press: Philadelphia, 1993, pp. 546-67. In her Marxist account of police, Harring argues that "the entire conception of a 'police society' emerged from the requirements of the ruling class of an increasingly complex urban society" (p. 562). Although her argument is valid regarding the expansion of centralized police forces in England in the mid-nineteenth century, the whole concept of police cannot be reduced to this task alone. More specifically, the idea of 'police society' mainly meant a civilized society because, in the seventeenth and eighteenth centuries, when the origins of the term police emerged and became prominent in the discourse of scientists and governing authorities, the working classes were still in the making and had not yet become a powerful source of resistance against the new governmental technologies. See Alan Hunt, "Police and the Regulation of Traffic: Policing as a Civilizing Process?" in Dubber, Markus D. and Valverde, Mariana (Eds.). The New Police Science, Stanford: Stanford University Press, 2006, pp. 168-184.
} 
police institution, hence to de-fetishize the concept.

\section{The Destiny of Police as an Enlightenment Project}

Police is a notion of the Enlightenment and early modernity. Its emergence reflects a complex process that evolved from notions of the state, good government, administration, the happiness of each and all, and the meaning of life. Hence, it is safe to say that the police project forms the very reason d'être of the political organizations of our modern societies. In Palgrave's Dictionary of Political Economy (1926), Henry Higgs explains:

it is to the police school that we owe registrations of births, deaths, and marriages, the census, the creation of Peasant Proprietors out of the wrecks of Feudalism, Sabbatarianism, compulsory education, and the idea of the duty of the state to counteract the mental superiority of employers by Employers' Liability Acts and other social legislation. Trade licenses also came to us through this channel. ${ }^{2}$

The police school and its ideal of police, since then, remained a modern project. Before considering its history, however, some thoughts should be given here on this group of scholars who discussed the concept between the late seventeenth and early nineteenth centuries.

In this thesis, the phrase 'police scientists' refers to those early modern writers who were heavily concerned with the question of police. My primary aim here is to understand the general patterns of the police literature in relation to new governmental mentalities,

${ }^{2}$ Henry Higgs (ed.), Palgrave's Dictionary of Political Economy, 1926, London: Macmillan and Co., p. 125. 
capitalist exploitation, and public order so as to understand the legacy for contemporary societies of this vast literature on police between the 1600s and 1800s. In doing so, while leaving the specificities of each country out, my conviction is that late seventeenth and eighteenth-century European philosophers were familiar with each other's texts. Despite the geographical distances, a philosophical community spirit maintained these discussions on police (i.e. on state and society matters), not as isolated islands but as collaborative, albeit deliberative, dynamic exchanges among the writers of the time. These writers were also quite influential in decision-making processes—so much so that Zygmunt Bauman refers to the philosophers of the time as legislators. ${ }^{3}$

In order to explore the history of ideas on police, I review various texts by Sir William Petty, Johann von Justi, Joseph von Sonnenfels, Sir John A. Fielding, Adam Smith, Cesare Beccaria, Jeremy Bentham, and Patrick Colquhoun. The rationale behind this non-random selection is very simple: the availability of their texts in English and the popularity of their names among contemporary police scholars and writers on police. Thus, I do not pretend to present a holistic analysis of the police school but rather I aim to convince the reader that the texts quoted here constitute part of the oeuvre in the making at that time. My aim here is to demonstrate through a few examples that police is a modern, scientific, and political project implemented by the philosophers-cum-'legislators' of the time.

3 Bauman, Legislators and Interpreters: On Modernity, Post-Modernity and Intellectuals, Cambridge: Polity Press, 1989. 
Petty (1623-1687) represents an early example of a police theorist working directly for England's ruling classes while the French police commissaire and police theorist Delamare's (1639-1723) four volumes of Traite de la Police (published between 17051738) were widely circulated and read by both foreign and local authorities. ${ }^{4}$ In Europe's German-speaking universities, Justi (1717-1771) and Sonnenfels (1732-1817) theorized and taught Germanic mercantilism, i.e. cameralism, within the field of Polizeiwissenshaft.

Fielding (1721-1780) took part in establishing the Bow Street Runners in London, the first example of a government-funded modern police force. While this was, of course, not the first time that paid detectives investigated crimes, it was the first time that detectives were asked to do so according to a certain mentality complying with the modern ideals of police theorists. I will address this question of what is modern about the modern police force of the late eighteenth century in the next chapter. Smith (1723-1790), on the other hand, when read from a different angle that places the concern of police at the center rather than his explorations on wealth and labour, plainly demonstrates how the police project works as a thread that links the state, capital, and liberal ideals like individualism: "[t]he establishment of commerce and manufactures, which brings about this independency, is the best police for preventing crimes." ${ }^{5}$

Beccaria (1738-1794), a prominent Italian philosopher, embraced the pure ideals of the Enlightenment while opposing the criminal law of his time. His significance in police studies, I argue, derives from the turn he represents in terms of thinking through criminal

\footnotetext{
${ }^{4}$ Neocleous, The Fabrication of Social Order, p. 4.

${ }^{5}$ Smith, Lectures on Jurisprudence, p. 204-205.
} 
issues. His writings, in a sense, represent a modern turn in thinking about issues regarding public importance as he explains crime in terms of ignorance, enslavement, and lack of observance. He acknowledges that, when enlightenment accompanies liberty and when men observe one another, the sources of crime will disappear. ${ }^{6}$ This makes Beccaria the most humanitarian or optimistic of the philosophers quoted here; yet his pure and seemingly naïve advocacy of Enlightenment ideals reveals the foundations on which the projects of police and the public were constructed.

The architect of utilitarianism, Bentham (1748-1832), who was deeply impressed with Beccaria's work, proposed his Panopticon. Although this was never implemented by the English authorities, it attracted enough attention to be presented to France's National Assembly while also earning Bentham honorary French citizenship in $1792 .{ }^{7}$ The full title, given in his collected letters, captures the main idea behind his design quite well:

Panopticon; or the Inspection-House: Containing the Idea of a New Principle of Construction Applicable to Any sort of Establishment, in which Persons of Any Description are to be Kept under Inspection; And in Particular to PenitentiaryHouses, Prisons, Houses of Industry, Work-Houses, Poor-Houses, Lazarettos, Manufactories, Hospitals, Mad-Houses, And Schools: With a Plan of Management

${ }^{6}$ Beccaria, On Crimes and Punishments, p. 93-98. It is interesting to read the influence of Rousseau's Emile on Beccaria's text. It is my contention that as much as education, his advocacy for surveillance, or the very mentality that renders it possible to think that "venality is more difficult among men who observe one another," comes from the Enlightenment philosophy. Then, the need for patrol officers can be linked to this education aspect of Enlightenment.

${ }^{7}$ Rigakos et al, A General Police System, p. 221. 
Adapted to the Principle: In a Series of Letters, Written in the Year 1787, From Crecheff in White Russia. To A Friend in England. ${ }^{8}$

Bentham's main aim is to achieve the most effective observation technique. As mentioned above, one of Beccaria's main concerns was also observation, while the other police scholars also all placed surveillance at the heart of their inquiries. This, I think, says a lot about the Enlightenment roots of the police ideal. I will come back to this point throughout the thesis as I try to link the Enlightenment, capitalism, police, and the public.

Colquhoun (1745-1820) was a magistrate who, in 1798, established the River Thames Police for a project funded by the West India Merchants, which comprised 50 officers supervising thousands of workers suspected of embezzlement. Stories of the River Thames Police's 'success' rapidly circulated around Europe. Colquhoun later wrote of his experiences in Treatise on the Commerce and Police of the River Thames (1800) while he had proffered the same kind of patrolling service for all London in his Treatise on the Police of the Metropolis (1796). ${ }^{9}$ Indeed, Foucault calls him "the creator of the police in England." 10 In his preface to Treatise on the Police of the Metropolis, Colquhoun states that

[p]olice in this country may be considered as a new science; the properties of which consist not in the Judicial Powers which lead to Punishment, and which belong to

\footnotetext{
${ }^{8}$ Jeremy Bentham, The Panopticon Writings, Miran Bozovic (ed.), London: Verso, 1995.

${ }^{9}$ Rigakos et al, A General Police System, p. 245.

${ }^{10}$ Foucault, 'Truth and juridical forms', in P. Rabinow and J. Faubion (eds), The Essential Works of Michel Foucault Vol.3, New York: The New Press, 1994, p. 69.
} 
Magistrates alone; but in the Prevention and Detection of Crimes, and in those other functions which relate to internal regulations for the well ordering and comfort of civil society. ${ }^{11}$

Referring to police as a science whose function is to regulate civil society, Colquhoun connects the eighteenth-century police ideal to the nineteenth-century police force. In this, one can trace how the broader police project (concerning the state's internal affairs) was reduced to the police in uniform. This conception of police also "combined law and economics, the protection of property and the protection of production."12

Thus, in the nineteenth century, the police project developed further under the impact of the ideology of modernism. ${ }^{13}$ That is, it began to be practiced in a systematic, institutionalized, hierarchic, asymmetric way through the police. Although the mentality of the police project remained very much the same, each changing police practice and each discussion regarding the role of the police in society defined and re-defined the role of the

${ }^{11}$ Colquhoun, Treatise on the Police of the Metropolis [1795].

${ }^{12}$ Peter Linebaugh, The London Hanged: Crime and Civil Society in the Eighteenth Century, London and New York: Verso, 2006 [2003], p. 427.

${ }^{13}$ Here I differentiate the ideology of modernism from modernity by following Habermas: "The word "modern" in its Latin form "modernus" was used for the first time in the late 5th century in order to distinguish the present, which had become officially Christian, from the Roman and pagan past. With varying content the term "modern" again and again expresses the consciousness of an epoch that relates itself to the past of antiquity, in order to view itself as the result of a transition from the old to the new ... the idea of being "modern" by looking back to the ancients changed with the belief, inspired by modern science, in the infinite progress of knowledge and in the infinite advance towards social and moral betterment ... The romantic modernist sought to oppose the antique ideals of the classicists; he looked for a new historical epoch, and found it in the idealized Middle Ages. However, this new ideal age, established early in the 19th century, did not remain a fixed ideal. In the course of the 19th century, there emerged out of this romantic spirit that radicalized consciousness of modernity which freed itself from all specific historical ties ... we are, in a way, still the contemporaries of that kind of aesthetic modernity which first appeared in the midst of the 19th century." Habermas, "Modernity versus Postmodernity", pp. 3-9. 
state. Then, through the police project commencing in the late seventeenth century, politics became more and more about the administration of the population. In order to understand the mentality of administration today, one therefore needs to be attentive as to what was modern about the police project from the late seventeenth to early nineteenth century. In addition to the discussion above, I want to emphasize three characteristics of policing as a modern project.

First, the police project is strongly related to modern scientific method. The resolutive-compositive method, adapted from Descartes and Bacon's methods and detailed in Hobbes's Leviathan, entailed following the processes of thought and experiment: after first taking something apart to find its fundamental elements, the scientist examines its fundamental elements in order to rationally reconstruct the necessary principles on which it works, and thereby rebuild the whole thing. It was no accident that Hobbes's close friend and one of the first writers on police, William Petty, is acknowledged as the inventor of political arithmetic — an earlier form of statistics as we know it today. ${ }^{14}$ As Foucault argues, knowledge became necessary in this period: "concrete, precise, and measured knowledge as to the state's strength." 15 Petty even went a step further, finding space to experiment on what he assumed to be true for the social order in Ireland. Justi, on the other hand, stressed that "[police] is that science which has for its object permanently to maintain the welfare of the separate families in an accurate correspondence and proportion with the best

\footnotetext{
${ }^{14}$ Along with John Graunt (1620-1674), Sir William Petty (1623-1687) is considered to be the founder of statistics. See George Rigakos and Richard W. Hadden, "Crime, Capitalism and the 'Risk Society': Towards the Same Old Modernity," Theoretical Criminology, 5:1, 2001, pp. 61-84.

${ }^{15}$ Foucault, “'Omnes et Singulatim': Towards a Critique of Political Reason,” [1979] 2000, p. 316.
} 
common good." ${ }^{\prime 6}$ For Sonnenfels, the science of police was one of the items categorized under science of the state (with the others being the sciences of human action, finance, and natural science). ${ }^{17}$ Thus, the population became an object of inquiry, with police scientists going to it and investigating it as 'knowing subjects' as in the case of natural sciences. ${ }^{18}$

Second, as a modern project, it is also totalizing in the sense that it defines the condition, form, and content of social order in its totality. That is, police is all about the state, civil society, family, and individual subjects, the combination of which may be referred to as the Commonwealth in the English-speaking world. The matters treated under the category of Polizei in the seventeenth century were as broad and vague as to include all affairs concerned with maintaining the community itself, as Franz-Ludwig Knemeyer puts it: "the concerns of 'Polizei' ... included all those areas where state power entered into social life." ${ }^{19}$ Writers on police were thus concerned with the basic principles of regulated social life, with the term police as much concerning society and individuals in their making of the public as it did the state and administration.

The third characteristic relates to two conflicting aspects of modernity as a political project: regulation and emancipation. According to Boaventura de Sousa Santos, modernity

\footnotetext{
${ }^{16}$ Joseph von Justi, Grundsatze der Polizeywissenschaft cited in Albion Small, 2001, p. 454.

${ }^{17}$ Joseph von Sonnenfels, cited in Albion Small, 2001, p. 495. I will explore the role of cameralism in the development of police ideas in the following parts of this chapter. Here, I shall suffice to note that cameralist police science was established to educate statesmen in German estates.

${ }^{18}$ As the example of Pasteur, clearly demonstrated by Bruno Latour in The Pasteurization of France, 1988, Cambridge: Harvard University Press: although a late example concerning that the same scientific method was established long before Pasteur's nineteenth century, in terms of the order of things and the main mentality, the case is representative of the early modern period.

${ }^{19}$ Knemeyer, "Polizei," p. 181.
} 
as a regulating practice "tends either to the maximization of the state, or the maximization of the market, or still the maximization of the community" while as an emancipating practice it "tends to the aesthetization, the scientificization, or the juridification of social practice." 20 That is, while modern ideals free people from the arbitrary power of the authorities by equipping them with legal rights and liberties, they also restrict the field of action by increasing institutionalization and proceduralization. In parallel, the early police idea of the 'happiness and well-being of the population,' was articulated through the regulation and emancipation of the population. In that sense, as Bauman clearly demonstrates, the road to fascism in modern societies is not an accident; rather, it is the very ideals of modernity, such as order-making, procedural rationality, division of labor, or putting morality and rationality in separate poles, which make fascism possible. ${ }^{21}$ Understanding the greater police project in this sense uncovers the mentality implementing these modern ideals. These three aspects of the modern police project will be explored in the following sections of this chapter against the background of the writings of early police scientists.

\section{The Re-invention of Police and Politics}

Knemeyer suggests that, although the police concept took on different meanings in different times and territories, in the sixteenth and seventeenth centuries, "scholars, on reading Greek philosophers of the state like Plato and Aristotle, recall the real origin of this

\footnotetext{
${ }^{20}$ See Boaventura de Sousa Santos, Toward a New Legal Common Sense: Law, Globalization, and Emancipation, 2004, p. 4.

${ }^{21}$ Bauman, Modernity and Holocaust, 1989, Cambridge: Polity Press.
} 
term [polis] and prepare the way for a significantly extended and deepened conception." 22 The polis (city-state) in the Greek sense of the word, says Arendt, "defined itself explicitly as a way of life that was based exclusively upon persuasion ... outside the walls of the polis meant outside the realm of politics." 23 When police scientists used the word police, then, they were referring to a certain way of life within the demarcated borders of their territory in which the power of the sovereign could no longer be arbitrary. Thus, good government, social order, and police referred to the same thing. What was called 'the art of government' in the Ancient Greek texts is now re-defined through 'the science of police,' which emerged first in France and then in German-speaking countries. Therefore, in the late seventeenth and early eighteenth centuries, rather than a new police or politics, there was the 'reinvention of police and politics.'

To understand this re-invention of 'the art of government' through 'the science of police,' one needs to consider the distinction Aristotle draws between arts, sciences, and politics (prudent action). Aristotle defines five ways by which the soul arrives at truth by affirmation or denial, namely science (episteme), art (techne), prudence or practical wisdom (phronesis), wisdom (sophia), and intelligence or intuition (nous). ${ }^{24}$ As he defines it, "the object of scientific knowledge is of necessity"; it deals with the objects that are invariable and non-deliberative. ${ }^{25}$ Art, on the other hand, is

\footnotetext{
${ }^{22}$ Knemeyer, "Polizei," p. 172.

${ }^{23}$ Hannah Arendt, On Revolution, p. 2.

${ }^{24}$ Atistotle, Ethics, Book VI-chp. 3, p. 206.

${ }^{25}$ Aristotle, Ethics, Book VI-chp. 3, p. 207.
} 
concerned with bringing something into being, and the practice of an art is the study of how to bring into being something that is capable either of being or of not being, and the cause of which is in the producer and not in the product. ${ }^{26}$

Consequently, art always involves an activity that is a means to an end. Prudence is concerned with "human goods, i.e. things about which deliberation is possible ... [it] is not concerned with universals only; it must also take cognizance of particulars, because it is concerned with conduct, and conduct has its sphere in particular circumstances. ${ }^{27}$ Political science and prudence, says Aristotle, are "the same state of mind, but their essence is not the same. ${ }^{28}$ Politics is considered as the fullest realization of prudence while prudence is also found at the lower levels of the household and individual. That is, a prudent man understands the management of both households and states. Prudent action is not a means to an end; it is an end in itself and that end is a practical good that is attained in action through deliberation. Prudence, as Aristotle clearly explains,

cannot be science or art; not science because what can be done is a variable, and not art because action and production are generically different. For production aims at an end other than itself; but this is impossible in the case of action, because the end is merely doing well. ${ }^{29}$

\footnotetext{
${ }^{26}$ Aristotle, Ethics, Book VI-chp. 4, p. 208.

${ }^{27}$ Aristotle, Ethics, Book VI, chp. 7, p. 212.

${ }^{28}$ Aristotle, Ethics, Book VI-chp. 7, p. 212.

${ }^{29}$ Aristotle, Ethics, Book VI-chp. 5, p. 209.
} 
The science of police of the seventeenth and eighteenth century, however, aims not at action but production, and in that it suggests both an art and science in Aristotelian terms but not politics (nor prudent action). ${ }^{30}$ Accordingly, police scientists of the time were obsessed with explaining and fabricating the political community rather than understanding and deliberating about it. ${ }^{31}$ On the other hand, police scientists were, in an Aristotelian sense of science, searching for an invariable object of study. French writer Antoine de Montchrestien complained in the Treatise of Political Economy [1615] that "[o]ne thing alone is lacking to you, O great State: the knowledge of yourself, and the image of your strength." ${ }^{32}$ To gain this knowledge of itself and see the image of its strength, the state needed to be studied through the scientific method as through this method one could raise a mirror to the state and its subjects.

As opposed to Aristotle's definition of society as a variable object of study, the police scientists preferred an invariable image of the state itself (and it should be kept in mind that the state and the entire society was still the same thing until the late eighteenth century). In the eyes of police scientists, political practices resemble scientific ones. Foucault, therefore, concludes that a very specific type of rationality was implemented

\footnotetext{
${ }^{30}$ In this sense, I think Mark Neocleous's book on the police powers could not be better titled. See Neocleous, The Fabrication of Social Order: A Critical Theory of Police Powers, London: Pluto Press, 2000.

${ }^{31}$ Although it would exceed the scope of this chapter to re-open the age-old debate between positivism and anti-positivism on the concepts of understanding and explaining, it should be noted here that with explaining I refer to an isolated definition of causalities of social occurrences while with understanding $I$ refer to a deeper comprehension of social occurrences through contextualization.

${ }^{32}$ Quoted in Pasquino, “Theatrum Politicum,” p. 114.
} 
regarding the rationality of state power through two sets of doctrines: the reason of state and the theory of police. ${ }^{33}$ To demonstrate, Foucault quotes the Italian writer Giovanni Botero [The Reason of State, 1589], who defines the reason of state as "a perfect knowledge of the means through which states form, strengthen themselves, endure and grow." ${ }^{34}$ Police scientists see the role of a statesman as more like the role of a physician. In 1765, Sonnenfels, although referring to Aristotle, wrongly claims that

We are convinced that the problematical and the variable do not reside in the principles of the science, but in the circumstances and occurrences to which the principles are to be applied. The mere empiricist in politics is therefore as little to be regarded as a statesman as the empiricist in the healing art is to be regarded as a physician. ${ }^{35}$

It was, however, Beccaria in the late eighteenth century who recognized the difference between natural and social sciences in terms of their method after the masses began to effectively resist new governmental technologies. Thus he suggests:

It is impossible to prevent all disorders in the universal conflict of human passions. They increase according to a ratio compounded of population and the crossing of particular interests, which cannot be directed with geometric precision to the public

\footnotetext{
${ }^{33}$ Foucault, “Omnes et Singulatim,” pp. 313-314.

${ }^{34}$ Giovanni Botero, quoted in Foucault, "Omnes et Singulatim," p. 314. It is worth mentioning that Botero opposed both Bodin and Machiavelli when they argued for the God-given power of the King. He preferred to legitimize power on the basis of the state's knowledge.

35 Sonnenfels, Grundsdtze der Policey, Handlung und Finanz, translated and quoted in Albion Small, The Cameralists: The Pioneers of German Social Polity, Kitchener: Batoche Books, 2001, p. 417.
} 
utility. For mathematical exactitude we must substitute, in the arithmetic of politics, the calculation of probabilities. ${ }^{36}$

It is therefore clear that as opposed to what Aristotle argued, the police scientists tried to create an object of inquiry that is 'demonstrable.' In that, they also had an end to reach other than the action itself-again in opposition to what Aristotle argued. One of the first writers who speaks no longer in the language of prince and his subjects but instead in that of population and Obrigkeit (a term which means authority but also public power or government) was Obrecht-who was also cited, to a great extent, in the writings of police scientists until the mid-eighteenth century. Obrecht defined the end that the art of government was trying to reach, writing in 1608 that there are three tasks of police: (1) providing information about population and territory; (2) implementing a set of measures to augment the wealth of the state; (3) increasing public happiness. He acknowledged that "the object of police is everything that has to do with maintaining and augmenting the happiness of its citizens, omnitum et singulorum (of all and of each)." ${ }^{37}$ In sum, the main task of police was to ensure census (the obligation of each citizen to pay his taxes) and censura (the task of the public powers to take in charge the people's lives, the life of each and all).

In his Discourse on Government and True Reason of State [1606], the Italian thinker Giovanni Palazzo made a more direct link between politics and art when he defined

\footnotetext{
${ }^{36}$ Beccaria, Crimes and Punishments [1764], Indianapolis: Bobbs-Merrill Educational Publishing, 1963, p. 63.

${ }^{37}$ Quoted in Pasquino, "Theatrum Politicum: The Genealogy of Capital - Police and the State of Prosperity," p. 113.
} 
reason of state as "a rule or art enabling us to discover how to establish peace and order within the Republic." 38 On the other hand, the German writer Philipp Chemnitz, in De Ratione Status [1647], argued that it was "a certain political consideration required for all public matters, councils, and projects, whose only aim is the state's preservation, expansion, and felicity; to which end, the easiest and promptest means are to be employed." 39 Then again, politics, or 'reason of state,' as Foucault calls it, was regarded as both art and science, in opposition to Aristotle.

Louis Turquet de Mayerne, in Aristo-democratic Monarchy [1611], identifies four grand officials besides the King: Justice, Army, Exchequer (taxes and revenues), and Police. When he states that "the police's true object is man," he suggests a mainly moral role for the police to foster "modesty, charity, loyalty, industriousness, friendly cooperation, honesty" among the people. ${ }^{40}$ Such ideas about police and the (reason of) state spread all through the seventeenth and eighteenth centuries "either as applied policies (such as cameralism or mercantilism) or as subjects to be taught (Polizeiwissenschaft, the title under which the science of administration was taught in Germany)."41 Sonnenfels suggested in his 1765 essay, in parallel to Turquet, that

the ultimate purpose of states may be divided into ... four sciences, viz.: external security; internal security; diversification of gainful occupations; and raising the

\footnotetext{
${ }^{38}$ Giovanni Palazzo, quoted in Foucault, “Omnes et Singulatim,” p. 314.

${ }^{39}$ Philipp Chemnitz, quoted in Foucualt, ibid., p. 314.

${ }^{40}$ Quoted in Foucault, ibid., p. 319.

${ }^{41}$ Foucault, “Omnes et Singulatim,” p. 320.
} 
revenues necessary for the expenses of the state: (1) Staatswissenschaft; (2) Polizeiwissenschaft; (3) Handlungswissenschaft, (4) Finanz-wissenschaft. ${ }^{42}$

Von Sonnenfels argued that natural sciences should be used in the service of Polizei, Handlung and Finanz, mainly because

the man of affairs, in actual administration, must know the customs, habits, and statutes of peoples, the reciprocal advantages and disadvantages of lands, the political conditions of states, and if he is to participate with advantage in lawgiving, he must know men. ${ }^{43}$

In the same vein at around the same time, Adam Smith was arguing that "[j] urisprudence is the theory of the general principles of law and government. The four great objects of law are justice, police, revenue, and arms." ${ }^{44}$ The legislative aspect of prudence, namely jurisprudence, then, involved this meticulous quantitative attention to particular affairsespecially that of finance-while, in Aristotle, enactment was the last step in a deliberative process and hence the first step in prudent action. ${ }^{45}$ Thus, the object of prudence- - whose

\footnotetext{
${ }^{42}$ Sonnenfels, Grundsdtze der Policey, Handlung und Finanz [1765], p. 470.

${ }^{43}$ Sonnenfels, Grundsdtze der Policey, Handlung und Finanz [1765], p. 471.

${ }^{44}$ Adam Smith, Lectures on Justice, Police, Revenue and Arms [1763], London: Kessinger Press, 1896, p. 3.

${ }^{45}$ In Ethics, Aristotle states that "Prudence concerning the state has two aspects: one, which is controlling and directive, is legislative science; the other, which deals with particular circumstances, bears the name that properly belongs to both, viz. political science. This latter is practical and deliberative; for an enactment is a thing that can be done, and the last step in a deliberative process [the last step in the analysis becomes the first in the ensuing course of action.]", Book VI-chp. 8, p. 213.
} 
original causes were variable and indemonstrable (axiomatic) — was turned into an invariable, demonstrable, and hence non-deliberative object; that is, population.

\section{II.I. The Art of Government as Police}

The ultimate good and happiness of people that are the main principles of politics mentioned in Aristotle's texts were thus reduced to wealth, although Aristotle had insistently emphasized that "wealth is obviously not the good that we are seeking, because

it serves only as a means; i.e. for getting something else." ${ }^{46}$ Meanwhile, politics (as prudent action) was reduced to political economy, which was a concern of individual households in the Ancients. Finally, political science was replaced with the more technical, end-driven police science. Thus, as Foucault puts it, the main question in the seventeenth century became: "How can one ensure that the state can be governed as well, as precisely, and as meticulously as a family?"47

Family in this period was regarded as both a model and an instrument to be used in building populations as nations. As early as 1598, the metaphor of family was used in England in defining the role of the king. King James I stated that

by the law of nature the King becomes a natural Father to all his Lieges at his Coronation. And as the father of his fatherly duty is bound to care for the

\footnotetext{
${ }^{46}$ Aristotle, Ethics, Book I-chp. 5, p. 69.

${ }^{47}$ Foucault, Security, Territory, Population, p. 103.
} 
nourishing, education and virtuous government of his children: even so is the King bound to care for all his subjects. ${ }^{48}$

The resemblance between family and the nation that police scientists draw upon gives some very important clues about the nation-building aspect of the science of police. On the one hand, the government of the household constituted an example for the government of the state in the sense of determining and administering the housekeeping matters of the state. On the other hand, family became a means to administer the state: police scientists looked into the ways of increasing the number of marriages, defining how relations should be organized in a family, and even stipulating how many members each household should have. The well-being of families was an indicator of the security of the nation, as Justi puts it:

The best common good is the ultimate aim of all civic institutions. But, we can imagine no best common good without the welfare of the separate families. To make these correspond with each other is accordingly in fact the main defense of the state, out of which its power and happiness must chiefly arise. ${ }^{49}$

At the heart of this meticulous concern for families lies, among others, the aim of building a strong nation. Communities had to be taught that what is in the interest of the nation is also in their own interest. Loader and Mulcahy thus suggest that

\footnotetext{
${ }^{48}$ Quoted in Dubber, Police Power, pp. 45-46.

${ }^{49}$ Joseph von Justi, quoted in Small, The Cameralists, p. 454.
} 
Police is concerned not merely with the protection and viability of states and statehood, but also with the formation and constitution of nations and national identities; a means by which membership and recognition within political communities are claimed, accorded, or denied, a vehicle through which such communities are styled, represented, and imagined..$^{50}$

The discourse of nation, therefore, became prevalent in social and political thought through the writings of police scientists - later turning into a concern for national security (referring less to public security) or national interest (referring less to public interest).

Such metaphors also helped re-organize the power structure between city, central authority, and citizens to the advantage of the central authority. Police science was intimately related to urbanization. For example, in 1765, Boucher d'Argis defines the term police as “'the art of providing a comfortable and quiet life' to all of the earth's inhabitants, but particularly to city dwellers". ${ }^{51}$ Nevertheless, although one may even claim, following Foucault, that "to police and to urbanize is the same thing," 52 it is not possible to argue that police science aimed at empowering cities when it comes to the juridical power of local authorities. Quite the contrary. As Engin Isin demonstrates, in English and European legal systems, "[u]ntil the fifteenth century the city was autonomous; it then became a

\footnotetext{
50 Loader \& Mulchany, Policing and the Condition of England:Memory, Politics and Culture, Oxford University Press: Oxford, 2003, pp. 45-46.

${ }^{51}$ Quoted in Brodeur, The Policing Web, Oxford: Oxford University Press, 2010, p. 47.

${ }^{52}$ Foucault, 2007, pp. 336-337.
} 
subordinate entity created by the State." ${ }^{53}$ Consequently, "the sphere of citizenship shifted from city to State." ${ }^{\circ 4}$ The family metaphor or paternalistic explanations centered on the king also reinforced this shift. This new body politic excluded the body natural of medieval cities, in which "a citizen was defined as an inhabitant of a city entitled to the rights and privileges of a "freeman." ${ }^{55}$ Sonnenfels draws a sharp distinction between educating a son and a citizen; hence, in a sense, he defines the new position of the citizenry in the eighteenth century:

After religion, education has the greatest influence upon morals. It is, to be sure, a peculiar duty of parents; but not only a son, a citizen is also to be educated. Education can therefore, on account of its connection with the common welfare, not be a matter of indifference to the law-giver, and cannot be left by the state to private whim. ${ }^{56}$

Political science was transformed in the seventeenth century onwards by the substitution of Aristotelian methods by the mechanistic, clockwork mechanisms of Descartes and later Newton. From then on, a new conception of the nation-state developed, embodied in the idea of police. The very raison d'être of police made it possible to imagine a centralized nation-state founded on law, whose power is directed towards its population

\footnotetext{
${ }^{53}$ Engin Isin, Cities without Citizens: The Modernity of the City as a Corporation, Montreal/New York: Black Rose Books, 1992, p. vii.

${ }^{54}$ Isin, ibid., p. viii.

${ }^{55}$ Isin, ibid., p. vii.

${ }^{56}$ Sonnenfels, cited in Small, The Cameralists, p. 423.
} 
within its demarcated territories. This re-invention of politics entails seeing the totality of population, i.e. the nation, as both the defining element and target of government.

Following Foucault, Markus Dirk Dubber argues that “[p]olicing meant governing the state as a household for the sake of its public police and oeconomy." ${ }^{57}$ Along with the nation-building aspect of police, this relates to the paternalist nature of modern politics that creates a separation between the giver and receiver of rights and benefits, thereby creating superior and inferior. ${ }^{58}$ As I mentioned above, modernity comes with two contradictory aspects: emancipating and regulating. Looking into the project of police through this contradiction, it is possible to argue that these two aspects actually do not contradict each other since the governing authorities attempted to emancipate people by regulating them rather than vice versa.

The regulatory aspect of police science found its meaning in the mediation of law. Legal regulations in this period consolidated morally fine and just conduct in the service of the new art of government. The civility of civil society emanated from being regulated through a constitution. This particular way of life thus found its meaning in the concept of

\footnotetext{
${ }^{57}$ M. D. Dubber, "The New Police Science and the Police Power Model of the Criminal Processes" in Dubber, Markus and Mariana Valverde (eds.) The New Police Science: Police Powers in Comparative Perspective, Stanford: Stanford University Press, 2006, p. 107.

${ }^{58}$ See Alan Hunt's critique of paternalism with regards to European social democracies, in particular that of welfare states. Hunt, Explorations in Law and Society, p. 171.
} 
'political community' or 'civil society': a community/society regulated through a constitution. ${ }^{59}$ As Beccaria stresses in 1764 :

Happy are those few nations that have not waited for the slow succession of coincidence and human vicissitude to force some little turn for the better after the limit of evil has been reached, but have facilitated the intermediate progress by means of good laws. ${ }^{60}$

Thus, the prudent political activity of both people and statesmen was defined in terms of their compliance with laws. Sonnenfels, for example, argues that "political or social virtue is the facility of ordering one's conduct in correspondence with the laws of the society."'61 Understood in these terms, police meant shaping and limiting one's field of action through law among other things. In the writings of police scientists, police and legislation were either used synonymously or to mean two different aspects of the same thing, as Sonnenfels explains at the beginning of his book:

[My] intention is to treat the internal constitution of a state in its interdependence, and in all parts of the public administration, and at the same time to investigate the sources of law-giving. Consequently I shall frequently use the words Polizey and Gesetzgebung [law-making/legislation] as synonymous. ${ }^{62}$

\footnotetext{
${ }^{59}$ It is apt to note that the same Greek word in Aristotle's Ethics was translated into English as 'political constitution' and 'civil government' in two different translations of the book. Compare Aristotle, Ethics, London: Penguin Books, 1976 and Ethics, Kindle Edition, Public Domain Books, 2005.

${ }^{60}$ Cesare Beccaria, Crimes and Punishments, p. 8

${ }^{61}$ Sonnenfels, cited in Small, The Cameralists, p. 429.

${ }^{62}$ Sonnenfels, cited in Small, The Cameralists, p. 426.
} 
It is worth mentioning at this point that a tension appears in texts on police science when they focus on legislation: a tension between the traditional (religious) and modern (secular). On the one hand, police scientists advocate completely conventional rules and regulations through a social contract in which both parties are this-worldly human beings; on the other hand, they are unwilling to spell out the resulting radical changes that would be unpleasant for both religious authorities and populations. In this sense, police scientists talk about a political virtue that represents a break with the tradition but does not contradict it; that relies on the scientific method but also dehistoricizes the rights discourse as they focus on universal human rights. Herein, law takes on the role of dehistoricizing, limiting, universalizing, but somehow moralizing political activity:

The distinction between grave and light should be fixed by the blind and impartial laws and not by the dangerous and arbitrary prudence of judges. Fixing of limits is as necessary in politics as in mathematics, not less in measuring size. ${ }^{63}$

Therefore, law here is not situated in opposition to police, as the discussions over the rule of law versus the rule of police would suggest; law rather constitutes the condition of police. Hence, the way the police project has dealt with law cannot be reduced to law enforcement. Instead, as Foucault points out, it was "a question not of imposing law on men, but of disposing things: that is to say, of employing tactics - to arrange things in such a way that, through a certain number of means, such and such ends may be achieved." ${ }^{64}$

\footnotetext{
${ }^{63}$ Beccaria, Crimes and Punishments, pp. 77-78.

${ }^{64}$ Foucault, "Governmentality," in The Foucault Effect, p. 95.
} 
Law became the governing technology of this new social order. Although the ruling classes mostly benefited from law, it was not only them who relied on it since law embraced the whole population. The rule of law thus introduced a "contradictory social relation, an arena of struggle ... something which the poor and the oppressed have struggled against, struggled within, and sometimes struggled for." ${ }^{65}$ Introduced to the poorer classes through contract work, it started to shape the lives of the working classes as well, providing them with the language in which these new relationships were articulated. It became a mediator between working bodies and land/capital owners, a bridge between workers and their means of subsistence. Even the most sustained and violent social upheavals were ultimately constrained to a struggle within the framework of a society based on law. However, although the law became a relation in itself, it cannot be differentiated from the rule of police. What police scientists had so long demanded in their writings was nothing but the rule of law. It is worth mentioning here again that, whenever police scientists spoke of 'civil society,' they were speaking of it in terms of 'society after the social contract' as society established on the basis of a set of rules is a civilized society. This makes it impossible to differentiate a constitutional society and/or state from a police society and/or police state. In this sense, my contention is that, while the rule of law embraced the whole society, a new conception of equality was born: equality before the law and equal opportunities. This was to be the type of equality ironically claimed by the working classes in the nineteenth century.

\footnotetext{
${ }^{65}$ Stuart Hall, "Law, Class and Control" in Mike Fitzgerald et al (eds.) Crime and Society, Routledge \& Kegan Paul: London, 1981, p. 492.
} 
As happens with each re-invention, the re-invention of politics over the course of the seventeenth and the eighteenth centuries transformed the existing meaning of politics as a way of life from its Ancient Greek meaning. The participatory political activity of the Ancient Greeks was reduced to the regulatory activity of the ruling classes, with demands from the social body only being taken into account insofar as they disturbed the stability of the state. Cultural crusades attempted to civilize the masses, all in the name of police. From this, I argue that the possibility of ideal political action in the way Arendt defines it — as an action that goes on among plural human beings, each of whom can act and start something new-did not originate in the structure of modern societies. ${ }^{66}$ That is, it is not the emancipatory nature of modernity that enables revolutionary political action but rather the dialectical nature of human activity and human-made social formations. Therefore, another aspect should be added to Arendt's definition: political action in spite of the politico-legal structure of modern societies. For the modern structure of politics builds directly on notions of social control and paternalism, which directly shape, and thus limit, possible political action. In this sense, over the course of the seventeenth and eighteenth centuries, the making of police also meant the making of the public.

\section{II.II. Politics as Political Economy under the Police Science}

It is widely accepted that Antoine de Montchrestien was the first to use the term political economy in his Treaties of Political Economy [1615]. He defines a country's wealth in terms of the necessities of life for its citizens: "it is not a plentiful supply of gold

\footnotetext{
${ }^{66}$ See Arendt, The Human Condition, pp. viii-ix.
} 
and silver or the quantity of pearls and diamonds that makes countries rich: it is the provision of clothing and the necessities of life." ${ }^{\prime 67}$ Rousseau, about a hundred year later, in his "Discourse on Political Economy" [1755], written for Diderot and D'Alembert's Encyclopedia, distinguishes between public and private economy, declaring that the state should have nothing to do with the latter. Rousseau distinguishes between public economy (which he calls Government, with its executive power binding on individuals) and the supreme authority (which he calls Sovereignty, with its legislative power binding the whole nation). In his analogy of the body politic, Rousseau equates public income to blood:

The sovereign power represents the head; the laws and customs are the brain, the principle of the nerves and seat of the understanding, of the will, and of the senses, of which the Judges and Magistrates are the organs; commerce, industry, and agriculture are the mouth and stomach which prepare the common subsistence; public finances are the blood, which a wise economy, performing the functions of the heart, sends out to distribute nourishment and life throughout the entire body; the citizens are the body and the members that make the machine move, live, and work, and no part of which can be hurt without the painful impression of it being straightaway conveyed to the brain, if the animal is in a state of health. ${ }^{68}$

Between 1615 and the early 1800s, political economy refers to those concerns regarding a method of government to increase the nation's prosperity: a sort of scientific reflection on

\footnotetext{
${ }^{67}$ Montchrestian, quoted in Michel Baridon, A History of the Gardens of Versailles, pp. 13-14.

${ }^{68}$ Jean Jacques Rousseau, "Discourse on Political Economy" in The Social Contract and Other Political Writings, Victor Gourevitch (trans. and ed.), Cambridge: Cambridge University Press, [1755]1997, p. 6. (Emphasis is original).
} 
the creation, organization, distribution, and limitation of wealth in a society.

Early writers on police were also mainly concerned with the wealth of nations. As Pasquino emphasizes, "to the old royal slogan of justitita et pax (justice and peace), there is now added this new one, prosperity." ${ }^{99}$ King James I, in his address to the parliament in 1603 , stated

whereas the proud and ambitious tyrant doth think his kingdom and people are only ordained for satisfaction of his desires and unreasonable appetites, the righteous and just king doth, by the contrary, acknowledge himself to be ordained for the procuring of the wealth and property of his people. ${ }^{70}$

In the seventeenth century, it was made clear that the state depends on its economy, but not only in the sense of having raw materials but also in the sense of its productive capacity and the means of production. A century later, Sir William Blackstone, in his Commentaries on the Laws of England [1769], clarified the relation between police and (political) economy:

By the public police and oeconomy I mean the due regulation and domestic order of the kingdom: whereby the individuals of the state, like members of a wellgoverned family, are bound to conform their general behaviour to the rules of propriety, good neighborhood, and good manners: and to be decent, industrious,

\footnotetext{
${ }^{69}$ Pasquino, “Theatrum Politicum,” p. 113.

${ }^{70}$ Quoted in Dubber, Police Power, pp. 45-46.
} 
and inoffensive in their respective stations. ${ }^{71}$

Improving the productive capacity of the state thus became the rallying cry of the science of police. The origins of political economy and its relation to capitalist exploitation of labour can therefore best be understood through the texts of police scientists as they were the first ones who attributed value to the productive capacity of labour. In this sense, my approach to police accords with Steven Spitzer's suggestion: "our [Marxist] understanding of police work and police institutions in class society must be forged from an examination of the entire framework of material relationships, conditions and conflicts within which these arrangements and interests emerge." ${ }^{\prime 2}$ It was through the science of police that the governing authorities turned their attention to population as a source of wealth. Therefore, how police science projected these material conditions on which the capitalist exploitation of labour could be maximised gains importance.

In his remarks on the transition from one governmental rationality (raison d'État) to another (modern governmental reason or liberal governmentality), Foucault explains that "fundamentally it was political economy that made it possible to ensure the selflimitation of governmental reason". ${ }^{73}$ Nevertheless, in this part, I will try to oppose Foucault's contention by arguing that it was police scientists between the seventeenth and nineteenth centuries (according to Foucault's periodization, they belong to the raison $d^{\prime}$ État) who made it possible to equate governmental reason to political economy, thereby

\footnotetext{
${ }^{71}$ Quoted in Dubber, ibid., p. xii.

${ }^{72}$ Spitzer, "The Political Economy of Policing", p. 571.

${ }^{73}$ Foucault, The Birth of Biopolitics, p. 13.
} 
reducing politics to state oeconomy. My claim is that political economy is not the point of separation between the two modes of governmental reason but the point of bringing the two together, i.e. bridging the absolutist police state of raison d'État to liberal and internally limited modern governmental reason. Police scientists played a crucial role in this while reducing politics to political economy, which became the main concern of modern governments from the late seventeenth century onward. As Dubber explains:

Police marked the point of convergence between politics and economics, when one mode of governance merged into the other, and created the oxymoronic science of political economy. The police power was born when the governmentality of the private (micro) household was expanded, and transferred, onto that of the public (macro) household. ${ }^{74}$

In his lectures on biopolitics, Foucault makes the case that political economy as a new governmental rationality emerged after raison d'État to replace its administrative form, i.e. the police state. Although Foucault argues that political economy "took up exactly the objectives of raison d'Etat and the police state that mercantilism and European balance had tried to realize," 75 I suggest, on the contrary, that political economy and police science went hand in hand from the very beginning. Thus, although Foucault refers to the Physiocrats as the first political economists, I would refer to police scientists as the first political economists for different reasons. Whereas Foucault claims that the Physiocrats advocated internal limits for governments, I argue that this happened first through the

\footnotetext{
${ }^{74}$ Markus Dirk Dubber, The Police Power, p. 81.

${ }^{75}$ Foucault, The Birth of Biopolitics, p. 32.
} 
emergence of police science as the new art of government.

When Foucault talks about change in the mid-eighteenth century with the emergence of political economy (first with the Physiocrats), he does not mean that governmental rationality was somehow dominated by the scientific knowledge provided by political economists. ${ }^{76}$ Instead, he refers to changes in the market-that it was transformed from being a site of jurisdiction to a site of veridiction. In this sense, the role of political economy was to point out to the "government where it had to go to find the principle of truth of its own governmental practice." "77 Foucault's attention to the market and its relation to changes in governmental reason demonstrates a relationship between the modes of production and power. The market is the one that formulates its own truth and proposes it to governmental practice as a rule or norm. Here we see a return to Foucault's famous power-right-truth triangle. However, when I say that politics has been reduced to political economy through the works of police scientists, I do not necessarily refer to capitalist political economy but rather to political economy as a governmental rationality. It is through the science of police that politics is understood as reproducing, observing, and governing the economic means of the state, or rather the public oeconomy. This parallels Marx's definition, referring to Petty as the first political economist:

by classical political economy, I mean all the economists who, since the time of W. Petty, have investigated the real internal framework [Zusammenhang] of bourgeois relations of production, as opposed to the vulgar economists who only flounder

\footnotetext{
${ }^{76}$ Foucault, ibid., p. 33.

${ }^{77}$ Foucault, ibid., p. 32.
} 
around within the apparent framework of those relations, ceaselessly ruminate on the materials long since provided by scientific political economy, and seek there plausible explanations of the crudest phenomena or the domestic purpose of the bourgeoisie. ${ }^{78}$

In 1769, Beccaria, although better known for his Crimes and Punishments (1764), in which he provides a strong moral basis to oppose capital punishment, was appointed to teach public oeconomy, and wrote A Discourse on Public Economy and Commerce. In this short text, he identifies the different aspects of public economy:

the study of public oeconomy must necessarily enlarge and elevate the views of private oeconomy, by suggesting the means of uniting our own interest with that of the publick. When accustomed to consider the affairs of the common weal, and often to call up the ideas of general good, the natural partiality we bear to our own reasonings, and to objects which afford us so much intellectual pleasure, re-kindles the languishing love of our country. We no longer look upon ourselves as solitary parts of society, but as the children of the public, of the laws, and of the sovereign. The sphere of our feelings becomes greater and more lively; the selfish passions diminish, and social affections are dilated, and gather strength from the power of imagination and habit; and measuring objects according to their real dimensions,

\footnotetext{
${ }^{78}$ Marx, Capital vol. I, pp. 174-175, f.n. 34.
} 
we lose sight of every mean and groveling disposition; vices which spring continually from a false measure of things. ${ }^{79}$

Thus, it can be argued that the public (or political) economy of the polis (or modern state) became the main concern of governing reason from the late seventeenth century onwards. Indeed it was regarded as the science whose advanced study would bring improvement.

\section{The Ideal of Police Science as Political Economy: Primitive Accumulation}

While improvement was the aim, the condition for achieving this objective was the use of free labour power. As Marx puts it, primitive accumulation

can be nothing other than the process which divorces the worker from the ownership of the conditions of his own labour; it is a process which operates two transformations, whereby the social means of subsistence and production are turned into capital, and the immediate producers are turned into wage-labourers. So-called primitive accumulation, therefore, is nothing else than the historical process of divorcing the producer from the means of production. ${ }^{80}$

It was in a sense "the original sin" of political economy from which, Marx argues, "dates the poverty of the great majority who, despite all their labour, have up to now nothing to sell but themselves." ${ }^{81}$ I try to show in this part how this original sin found its reflection in the texts of police scientists regarding the enslavement of labour, enclosure, and

\footnotetext{
${ }^{79}$ Cesare Becaria, A Discourse on Public Economy and Commerce, http://socserv.memaster.ca/econ/ugcm/3113/beccaria/pubecon (reached on July 14, 2015)

${ }^{80}$ Marx, Capital vol. I, p. 874-875.

${ }^{81}$ Marx, Capital vol. I, p. 873.
} 
improvement.

In the late seventeenth century, the value of labour for increasing productive capacity and the wealth of a nation was spelled out by number of scientists. In 1676, for example, Petty defined labour as "the simple motions of men in order to commodities, for so many hours as he is naturally able to endure the same," 82 calculating that "each young Englishman who dies represented a net loss of $£ 69$ sterling." ${ }^{83}$ By 1689, John Locke described labour more systematically as the only component adding value to any product:

it will be but a very modest computation to say, that of the products of the earth useful to the life of man nine tenths are the effects of labour: nay, if we will rightly estimate things... what in them is purely owing to nature, and what to labour, we shall find, that in most of them ninety-nine hundredths are wholly to be put on the account of labour. ${ }^{84}$

Based on these rational-scientific calculations, the source of wealth and the mode of property were re-defined. Police scientists, concerned with the art of government need for a nation to reach its ultimate goal of happiness and prosperity, recognized the significance of surplus value, which in turn drew the attention of the ruling classes to the condition of the poor. As Colquhoun suggested, "this precious commodity, labour," could "only be appropriated from the poor" $" 85$ but to obtain more and more utility from the poor,

\footnotetext{
82 Petty, The Petty Papers, vol. I, p. 210.

83 Pasquino, "Theatrum Politicum," p. 116.

84 John Locke, Two Treatises of Government, p. 221.

${ }^{85}$ Colquhoun, A Treatise on the Police of the Metropolis [1797], p. 366.
} 
governments had to take sufficient care of them.

Before going into the details of this care, I shall briefly mention here what it meant to attribute value to labour power from the mid-seventeenth century onwards. Two concepts that occupied a considerable space in the early police literature were improvement and industriousness in relation to prosperity (or to the Wealth of Nations). When the Royal Society was founded in 1660 as a scientific advisory board to the government, it brought together some of country's most prominent scientists, including Petty and Robert Boyle. Through their work, a new body of literature emerged that spelt out the techniques and benefits of improvement. ${ }^{86}$ Improvement meant not only new techniques and better methods of farming while eliminating the old customs and practices that prevented the most productive use of land but also fundamentally "new forms and conceptions of property." ${ }^{87}$

Regarding property rights, there was a clear shift from passive rent-collecting landlords to more active, hands-on landlords. Locke identified this new form of property and criticized those landlords who did nothing to improve their land — meaning improving the productive capacity of their land and their workers - while collecting the rent. ${ }^{88}$ Petty, on the other hand, discussed how to create the conditions for productivity. While collecting rent might satisfy the landlord, the nation needed to accumulate more and more wealth. Therefore, from the peasant poor to the landlords, every single person needed to

\footnotetext{
${ }^{86}$ See Ellen M. Wood, The Origin of Capitalism, pp. 106-107.

${ }^{87}$ Wood, ibid., p. 107.

${ }^{88}$ Locke, Two Treatise of Government, pp. 395-396.
} 
comprehend that what was good for the nation was also good for them, which was the motto of civil society since Hobbes. Neocleous reminds us that, during the eighteenth century, a number of Improvement Acts were passed in Britain, a significant portion of which were solely concerned with the problem of maintaining social order during urbanization. It is therefore not surprising that these acts were also known as 'police acts. ${ }^{8}$

Along with the discovery of the value of labour and improvement came the discovery of the value of exclusive ownership of the land. In order for a landlord to gain more from his land, everything on it needed to be exclusively his own property, with all common rights over the land denied, specifically through enclosure. In the seventeenth century, what E.P. Thompson calls "a plain enough case of class robbery" became an increasingly common form of government of the land. ${ }^{90}$ It was robbery precisely because "[e]nclosure meant not simply a physical fencing of land but the extinction of common and customary use rights on which many people depended for their livelihood." ${ }^{11}$ The fence, nevertheless, is significant here when it comes to the police project as it represents the core of private property and the primitive form of the capitalist accumulation so fencing activity says more to us: "[t]he fenced-in space, as enclosure, constitutes a police zone" and hence "[t]he act of breaking a fence ... was an act of war." ${ }^{2}$ Throughout the eighteenth century, as this new form of property gradually gained legitimacy in Parliament, it was implemented

\footnotetext{
${ }^{89}$ See Neocleous, War Power, Police Power, Edinburgh: Edinburgh University Press, 2014, p. 68.

90 E. P. Thompson, The Making of the English Working Class, London: Penguin Books, 1991, p. 218.

91 Wood, The Origin of Capitalism, p. 108.

92 Neocleous, War Power, Police Power, p. 68.
} 
in village after village. ${ }^{93}$

The poor, however, did not accept this new regulation without dissent. The enclosure riots of the seventeenth century were so significant that enclosure surfaced as a major grievance in the English Civil War (1642-1651) ${ }^{94}$ However, this resistance could not reverse the pauperization of the peasant poor and their loss of immediate access to their means of subsistence. In this way, two targets were reached in tandem: on the one hand, production for both consumption and accumulation was guaranteed; on the other hand, separating peasants from their immediate sources of subsistence motivated them to do paid labour more and more just to meet their means of subsistence. This process is best described by Adam Smith in his brief account of the history of English feudalism—in which he also stated that the opulence of a nation does not lie in the quantity of money but in the abundance of commodities:

Under the feudal constitution there could be very little accumulation of stock ... The peasants had leases which were dependent upon the caprice of their masters; they could never increase in wealth, because the landlord was ready to squeeze it all from them, and therefore they had no motive to acquire it. As little could the landlords increase their wealth, as they lived so indolent a life, and were oppressed by all ranks, and were not able to secure the produce of their industry from rapine and violence ... but after the fall of the feudal government these obstacles to industry

\footnotetext{
93 Thompson, The Making of the English Working Class, p. 218.

94 Wood, The Origin of Capitalism, p. 109.
} 
were removed, and the stock of commodities began gradually to increase. ${ }^{95}$

Wealth was increasingly defined in terms of commodities rather than money, which Smith called "a dead stock in itself" ${ }^{96}$ For Smith, every commodity had two different prices: its natural price and its market price. ${ }^{97}$ One of the tasks of police was to ensure "plenty and cheapness" of commodities while also maintaining security and cleanliness. ${ }^{98}$ It is important to note that this role regarding commodities at the national level is a regulatory one. It is a task of establishing and maintaining proposed exchange and property relations nationally, where civil society (the market), families, and individuals could not be trusted without proper regulations. This proves Neocleous's point that police and political economy constitute two sides of the same coin. ${ }^{99}$ Both theoretically and practically, therefore, the notion of police connected the state, landlords, labour, commodities, wealth, and the welfare of the population.

As Smith puts it, the main rule of capitalist exploitation means that "the price of labour by no means determines the opulence of society; it is only when a little labour can procure abundance." 100 Colquhoun agrees with Smith on this when he quotes from

\footnotetext{
${ }^{95}$ Adam Smith, Lectures on Justice, Police, Revenue and Arms, p. 220.

${ }^{96}$ Smith, ibid., p. 191.

${ }^{97}$ Smith, ibid., p. 173.

${ }^{98}$ Smith, ibid., p. 4.

99 See Neocleous, "Social Police and the Mechanisms of Prevention," British Journal of Criminology, 40, 2000, pp. 717-718. Although in this particular article Neocleous limits his argument by starting his analysis of police and political economy from Patrick Colquhoun (a late eighteenth-century figure), I would argue that the same connection between police and political economy could easily be built from the early seventeenth century onwards.

${ }^{100}$ Smith, Lectures on Justice, Police, Revenue and Arms, p. 165.
} 


\section{Middleton's View of the Agriculture of Middlesex:}

It is a general rule, that the higher their [labourers] wages, the less they carry home, and consequently the greater is the wretchedness of themselves and their families. Comforts in a cottage are mostly found where the man's wages are low, at least so low as to require him to labour six days a week. ${ }^{101}$

Thus, as well as discovering the value of wage labour for producing wealth, this era also celebrated the value of cheap wage labour. Smith also went a step further by justifying wage labour on the basis of freedom, which was to define a moral code as well:

Nothing tends so much to corrupt mankind as dependency, while independency still increases the honesty of people. The establishment of commerce and manufactures, which brings about this independency, is the best police for preventing crimes ... Nobody will be so mad as to expose himself upon the highway, when he can make better bread in an honest and industrious manner. ${ }^{102}$

That is to say, only those who have economic independence-in other words, who do not rely on anything other than their own labour to obtain their means of subsistence—can be free.

These theories went in tandem with practice. As Thompson shows, the first severe reductions in wages occurred at the beginning of the nineteenth century when employers demanded a 'legal' minimum (not maximum) wage to guarantee fair competition with their

${ }^{101}$ Colquhoun, ibid, p. 85.

${ }^{102}$ Smith, ibid, pp. 155-156 (emphasis is mine). 
rivals. As Thompson reports, one magistrate in 1818 claimed that "some years ago the weavers were so extravagantly paid that by working three or four days in the week they could maintain themselves in a comparative state of luxury." 103 The author of the Memoirs of Wool was writing along the same lines:

It is a fact well known...that scarcity, to a certain degree, promotes industry, and that the manufacturer who can subsist on three days' work will be idle and drunken the remainder of the week ... The poor in the manufacturing counties will never work any more time in general than is necessary just to live and support their weekly debauches ... We can fairly aver that a reduction of wages in the woollen manufacture would be a national blessing and advantage, and no real injury to the poor. ${ }^{104}$

The methods of their discipline allowed police scientists to draw a relatively clear boundary between the working bodies of the poor and indigent populations. In a sense, as Marx puts it very clearly, " $[\mathrm{t}]$ he fathers of the present working class were chastised for their enforced transformation into vagabonds and paupers." 105 According to Marx, "the agricultural folk were forcibly expropriated from the soil, driven from their homes, turned into vagabonds, and then whipped, branded and tortured by grotesquely terroristic laws into accepting the discipline necessary for the system of wage-labour." ${ }^{106}$ Not surprisingly,

\footnotetext{
${ }^{103}$ Quoted in Thompson, The Making of the English Working Class, p. 306.

${ }^{104}$ Quoted in Thompson, ibid, p. 306.

${ }^{105}$ Marx, Capital vol. I, p. 896.

${ }^{106}$ Marx, ibid., p. 899.
} 
almost all police scientists had a classification system for the poor in order to fit them into this necessary discipline. Among them, Colquhoun divided the poor into five classes: (1) the useful poor (able and willing to work); (2) the vagrant poor (able but not willing to work); (3) the indigent poor (willing to work but not able to do so); (4) the aged and infirm poor; (5) the infant poor (the abandoned children of the public). ${ }^{107} \mathrm{He}$ also defined different mechanisms of exploitation and discipline for each class. Accordingly, the first category of the poor is the most precious one, but they needed attention from the government to prevent them falling into the second category. The second category is the most damaging for the well-being of the state so they require meticulous surveillance. Therefore, Neocleous rightly argues that "[t]he key to prevention is thus not directly preventing crime, but preventing the class of poverty from falling into indigence."108

In addition to Neocleous's remark above, this classification indicates two further crucial points. First, police scientists draw a clear picture of society on the basis of the objective conditions for waging class warfare. Second, these categories presume a kind of solidarity among the people of each class: a form of solidarity that both ties people and divides them on the basis of (non)industriousness. Police scientists then deploy a new kind of solidarity while eliminating the traditional one. This later becomes the basis for the claims of fraternity found in the ideology of liberalism in the nineteenth century.

The 'scientific' discovery of the significance of labour power drew the ruling classes' attention to the population. Producing wealth for the sake of wealth functioned on

\footnotetext{
${ }^{107}$ See Colquhoun, Treaties on the Police of the Metropolis, p. 370.

${ }^{108}$ Neocleous, "Social Police and the Mechanisms of Prevention," p. 715.
} 
"dual levels of promise and blackmail." ${ }^{109}$ In order for the state to obtain prosperity and establish the population's happiness and well-being, the people had to labour more, not for themselves but for the well-being of society. To achieve this task, the labouring population was subjected to new regulation regarding the methods of production. They were disciplined through different mechanisms, such as low wages and criminalization of customary takings.

Given that a well-ordered public was their utopia, police scientists not only created a literature on the art of government but also theorized and implemented a new mode of governmental conduct with a distinct structure, rationality, and social impact. The effects of these particular ways of promoting order, control, and civility were to surface more and more during popular uprisings in the nineteenth century. Whenever help to the poor is conditional, control over people's activities becomes inescapable. With the emergence of the modern state, citizens became responsible for their actions, being given tasks regarding the government that made them open to social control, even in their day-to-day lives. They had to be subjected to wage labour. After all, political economy refers to the ways in which the state is to be governed just like the government of a household as Rousseau clearly explains in his "Preface" to A Discourse on Political Economy:

The word Economy, or Oeconomy, is derived from oikos, a house, and vomos, law, and meant originally only the wise and legitimate government of the house for the common good of the whole family. The meaning of the term was then extended to

\footnotetext{
${ }^{109}$ Pasquino, “Theatrum Politicum,” p. 113.
} 
the government of that great family, the State. To distinguish these two senses of the word, the latter is called general or political economy, and the former domestic or particular economy. ${ }^{110}$

Police science defined the details of this kind of government that views the nation as a huge household to be taken care of. It is not surprising to read Justi's definition of a prudent nation:

two theorems which will be of great importance in the whole treatment of Policey: First, a prudent nation must always take care to put itself in such condition that it is not under the necessity of obtaining its most important wants and materials from other peoples; second, a nation must seek in every possible way to cultivate the area which it occupies and to improve its climate. ${ }^{111}$

\section{Conclusion}

In this chapter, I have presented a brief history of police from a political perspective. In doing so, I defined police as an Enlightenment project, concerned with mass education, observation, scientification, regulation, emancipation, and totalisation. I argued that, in the eighteenth century, police science re-invented both police and politics by replacing the Aristotelian method with the mechanistic one. I claimed that the police school reduced politics to political economy, in that all issues concerning the public became linked to the labour process and the economy. Following Neocleous's line of argument, I also argued

\footnotetext{
110 Jean Jacques Rousseau, A Discourse on Political Economy, p. 1.

${ }^{111}$ Justi, Grundsatze der Polizeywissenschaft, quoted in Small, The Cameralists, pp. 383-384.
} 
that primitive accumulation relates to the police project.

Police scientists explained how to deal with the labouring population under the capitalist mode of production. Of course, they were unable to imagine the most effective means to achieve their ends, and in fact most of their assumptions failed over the course of the nineteenth-century working-class riots. However, the structure, justification, and legitimation methods they utilized have been transformed and are still used in modern societies today. I am not claiming here that the science of police tells us everything regarding the rules and motions of capitalism. However, what I tried to demonstrate in this part is that the capitalist exploitation of labour is a product of a well-designed and detailed project of modernity. This historical stage was neither inescapable nor did it provide the best attainable good for human development. 


\section{CHAPTER FOUR}

\section{THE GREAT MEDIATOR: THE POLICE OF THE PUBLIC}

To society-at-large, the police are what the dream is to the quotidian round of events; what it excludes from its own preoccupations, at least as far as possible, polite society authorizes its police force to deal with ... Charged with the drainage of dreams, the police catch them in their filters. And that explains why policemen bear such resemblance to those they pursue.

Jean Genet, Querelle, 1947

Research over the last four decades seeking to move beyond taken-for-granted notions of police have demonstrated that the emergence of modern police (both as an ideal and institution) cannot be separated from the formation of the modern nation-state. ${ }^{1}$ Police power, in this sense, should be understood as one key to the making of modern times. The utopian aim of eighteenth-century police scientists was first to re-shape the spheres of action to make them policeable, then to individualize the population such that people cannot form a whole, and finally to totalize them so that they can be dealt with under the same socio-legal terms. Ordering the social sphere and separating it into dualities, such as public and private, state and civil, political and economic, or urban and rural, were modern abstractions inherited from Enlightenment thought. In Marx's words, "the abstraction of

1 To name just a few, see Foucault, Security, Territory, Population, 2004; Neocleous, The Fabrication of the Social Order, 2000; Dubber, The Police Power, 2005, Rigakos, Security/Capital: A General Theory of Pacification, Edinburg: Edinburg University Press, 2016. 
the state as such belongs only to modern times, because the abstraction of private life belongs only to modern times. The abstraction of the political state is a modern product."2

As mentioned earlier, one part of the aim of this thesis is to reveal the secrets of two abstractions of the modern times: the police and the public. I refer to them as the projects of police and the public since they are both products of the broader project of modernity. Yet, this does not mean that they were projects that functioned perfectly or created "the well-ordered police state." ${ }^{3}$ Rather, I describe them as projects in order to emphasize the opposite because I am convinced that governing through projects is "always incomplete, it consists of attempts and is always subject to avoidance, evasion and resistance."4 Thus, I aim in this chapter to reveal the relation between the two projects in their making of the modern social order. The two projects share common ground as components of the new art of government. The new mode of power, i.e. police power, emerged in the early eighteenth century not necessarily as a product but surely as a good companion to the new mode of production, i.e. capitalist production. Therefore, in my attempt to demonstrate how both projects of police and the public frequently come together, I focus this chapter on the issues of the commons, public order, and the transition from the police ideal to the police institution, exemplified through massive enclosures, urbanization, and the formation of the police institution in England in the eighteenth century.

\footnotetext{
${ }^{2}$ Marx, Critique of Hegel's Philosophy of Right, 1844.

${ }^{3}$ Marc Raeff, "The Well-Ordered Police State and the Development of Modernity in SeventeenthandEighteenth-Century Europe: An Attempt at a Comparative Approach,” 1975.

${ }^{4}$ Hunt, “Governing the City: Liberalism and Early Modern Modes of Governance," 1996, p. 174.
} 
In the first part, I look at the role of police science and the project of the public in the eighteenth-century enclosures. Primitive accumulation is not only about accumulating private property for capital (through exclusive control of the land) required for the new mode of production and its political economy. An equally important aspect of primitive accumulation is the ways in which, the technologies and rationalities through which enclosures were made possible in the moral economy of the commons. Therefore, in this part, I analyse eighteenth-century debates concerning enclosures to demonstrate how discursive and non-discursive practices shifted focus towards the new mode of power. ${ }^{5}$

In the second part, building on the discussion in the first part, I focus on eighteenthcentury concerns for public order, particularly regarding urbanization. I explore the relation between the police project, enclosure, and urbanization, and the project of civilizing the dangerous classes to make them urban settlers. Urbanization in the eighteenth century relates to both the police and public projects as the way cities were organized, ordered, policed, and governed shaped the day-to-day conducts of the occupants. Although cities did not emerge suddenly in the eighteenth century, urbanization as a process continued to represent the targets and means of the new mode of both power and production increasingly in the eighteenth century. In short, the second part argues for the utmost importance of eighteenth-century urbanization.

\footnotetext{
${ }^{5}$ While it is well-established that enclosures had been going on since the thirteenth century, it was in the eighteenth century that they generated the backbone of the new mode of production and were implemented widely. The Statute of Merton (1235) and Westminster II (1285) gave it a legal framework while it was suggested that the landlords should respect the rights of commoners.
} 
In the last part of the chapter, I discuss the mediating role of the police when it becomes the police of the public in the late eighteenth century. I inquire into the transition from the 'so-called' police state of the seventeenth and eighteenth centuries to the public police of the nineteenth century, with a focus on the question of continuity in police power. In a sense, I unfold the police project as a thread that links enclosure to urbanization and to the communication function of the uniformed police. Overall, the chapter should read as a place where I discuss various important issues in the eighteenth century to understand the nineteenth-century police and its making of the public sphere.

A note of caution should be entered here against a widespread tendency to attach significance to liberalism in relation to the projects of police and the public. Starting from the mid-seventeenth century, the development of police science that established the basis of modern politics perpetuated the kind of political order specific to capitalist societies. The new political order was about the modern mode of governing, which also enabled political ideologies, including liberalism, to emerge in the nineteenth century. In contrast to the widespread conviction about the relation between liberal thought and police, I argue that, in order to understand the workings of both projects of police and the public, one needs to think beyond the assumptions hidden in a liberal framework to recognize that the changes initiated through police science were not as closely related to liberal ideology as we accept them today. ${ }^{6}$ Instead, they are projects with distinctly modern trajectories. The

\footnotetext{
${ }^{6}$ It was Foucault who first tied the eighteenth-century police project to liberalism in his lectures collected under the title of The Birth of Biopolitics. Neocleous, too, in his Critique of Security, argues against the liberal ideal that pits freedom against security. Although both writers' general arguments are persuasive, I think they fail in limiting the police project to the ideology of liberalism. As both demonstrated in their work, the science of police and the police project had become the
} 
modern nation-state formation (which is a constant process) contains fascism as much as it contains socialism and liberalism. Thus, it can be argued that the modern nation state is just a moderate form of what all these conflicting modern ideologies imagine as a state. If so then what we are to look at is not (and should not be) the workings of liberalism as the dominant political ideology of our times but the workings of this new form of government that expressed itself in the concept of police in the late seventeenth century.

\section{The Question of Constant Primitive Accumulation}

Here, I would like to draw attention to 'constant' primitive accumulation in the form of enclosures and its relation to the projects of police and the public that began in the eighteenth century when, in Marx's words, "the law itself becomes ... the instrument of the theft of the people's land."7 While it expanded massively in the eighteenth century, commodification of land and other natural resources is a constant process under capitalist accumulation, as Luxemburg demonstrated. ${ }^{8}$ By focusing on the eighteenth-century

primary concern of governing authorities long before liberalism as an ideology emerged. Thus, limiting the presumptions of the police project in their shaping of power relations and the relations of production to the utopia of liberalism would be mistaken. It is indeed modernity, not liberalism, which dominated the interplay of relations of power starting in the eighteenth century, as I tried to show in the previous chapter. It was modernity that paved the way to political economy as a new art of government, with the projects of police and public as the main components of this art of government.

${ }^{7}$ Marx, quoted in Corrigan and Sayer, The Great Arch, 1985, p. 97.

8 Rosa Luxemburg, The Accumulation of Capital, Agnes Schwarzschild (trans.), London: Routledge and Kegan Paul Lim., [1913]1951. Capital accumulation continues through newer and older strategies. Gentrification, for example, as a newer strategy, is an important aspect of constant primitive accumulation as space was re-designed and re-commodified for higher value at the expense of existing and traditionalized 'common' rights. Commodification of once 'natural' and commonly benefited resources, as an older strategy, continues to encompass previously untouched resources, such the rivers to build hydro-electrical power plants in Turkey or tar sands to extract oil in Canada. 
enclosure movement I aim to emphasize two points in this part. First, enclosing the commons stimulated the project of the public as we understand it today. I call this process the making of the public through enclosure. My second point relies on published discussions about the commons among the gentry in eighteenth-century England. As put clearly by J.M. Neeson, the gentry formed two sides in the debate on enclosures: critics and supporters of the commons. ${ }^{9}$ In what follows, based on Neeson's work, I highlight the similarities between the arguments raised by critics of the commons and police scientists in the eighteenth century to argue that the general arguments of police scientists not only helped but also, to a certain extent, emerged out of this discussion on the commons.

I should note at the outset that I do not limit the definition of the commons to a certain space marked as the commons. Neither do I limit myself to those whose only means of subsistence was the produce of such common space when I speak of commoners. The commons here refers to a much broader spectrum of space, produce, activities, and people encompassing anything and everything over which customary common rights could be claimed and enjoyed by those commoners who used the commons in their daily life. Accordingly, in my approach here, commoners encompass a greater population than the landless commoners of rural areas. I prioritize their experience rather than a strict definition based on a relatively fixed space because experience of the commons was crucial for the projects of police and public.

9 J. M. Neeson, Commoners: Common Right, Enclosure and Social Change in England 1700-1820, Cambridge University Press, 1993, pp. 15-52. 


\section{I.I. The Making of the Public-Private Divide through Enclosure}

For a long time within Marxist scholarship, processes of commodification were often conceptualized under the term privatization, based on the argument that, through these processes of commodification, what had once been common was deemed private, separated for private use and situated in opposition to its public use. ${ }^{10}$ Yet, it seems to me that equating commodification with privatization has been a mistake. ${ }^{11}$ Furthermore, it has been a mistake to situate public use of a (re)commodified 'common' (such as land, water, forest, park, and so on) in opposition to its private use by private owners. Instead, I suggest that private and public constitute two sides of the same coin while both stand in opposition to common. I aim to establish in this part that 'making public' and privatization are simultaneously developed dual processes standing in dialectical opposition to commons. My intention is to establish commons in opposition to private and public, both theoretically and empirically, as they unfold at both levels in different times and spaces.

The public-private binary is a simplified binary of the Enlightenment, applied to and embodied in legal regulations through massive enclosure of commons to create a

\footnotetext{
10 Exemplary here is those Marxist critiques of neoliberalism such as David Harvey's 'accumulation by dispossession.' See Harvey, "The New Imperialism: Accumulation by Dispossession," Socialist Register 2004, pp. 64-87. Although consistent in itself, such works are problematic as they attribute normative value to the public property. However, I argue that public property might not serve to the best interest of the masses as in the case of the properties belonged to Armenian community in Turkey or the land belonged to Kurdish communities that have been nationalized by the Turkish government. The problematizations therefore should start from the commodification, and the ways in which goods, services and properties are commodified.

11 For a similar line of argument distinguishing between dispossession, exploitation, and commodification to seek answer to the question of pacification as a general system of policing see Rigakos, Security/Capital: A General Theory of Pacification, Edinburgh: Edinburgh University Press, 2016.
} 
modern order polarized between public and private, and public-ized and privatized. While privatization is widely used as a process, it is forgotten that 'making public' is equally a process, and that what is public has been historically made public out of what was common. Nevertheless, making public out of common or private is described without reference to the actual public, as in 'nationalize,' 'expropriate,' 'confiscate,' while the term publicization does not exist in English.

The terminology here is important as the commons comes with common rights, but public or public-use comes with roles and responsibilities, not necessarily towards others but primarily towards the legal entity of the state, translated through laws and regulations. Then, there is the question of jurisdiction. Public use contrary to common use makes people subject to legal procedures. Under such procedures, the space in question belongs to the state (or better yet, belongs to the legal system), not the people. More importantly, space itself is defined as something that can be owned by legal or natural persons. When it comes to the question of agency, while common use makes one simply a commoner, public use makes one a 'private person.' Thus, it is safe to argue that public and private are two sides of the same coin under the modern social order, and that they stand in dialectical opposition to the commons. ${ }^{12}$

It is important to think through the concepts of public and private in opposition to the commons while considering the question of police, mainly because the practices of

\footnotetext{
${ }^{12}$ This is part of the reason why the contemporary debate among the leftist intellectuals to re-claim the commons is not part of my inquiry here. Re-claiming commons under the public-private division is rarely a possibility. For the contemporary discussion on the commons see Douzinas, Costas, Slavoj Žižek, and Alex Taek-Gwang Lee (ed.), The Idea of Communism, London, New York: Verso, 2010.
} 
making public or private require policing the particular space and/or property. In this sense, making public can be considered as a way of taking away what is common. Public must be regulated, watched over, supervised, or policed by external authorities (who do not necessarily benefit from what is supervised). The commons, however, cannot be because they are regulated informally by their own beneficiaries without mediators. Thus, alienation is inherent in public since users of public space lack direct control over its management. In the same vein, 'public order' is a policy to be achieved in modern times, yet commons cannot be identified with 'order,' which necessarily involves ranking, grading, classifying and hierarchizing things by supervisors. ${ }^{13}$

Similarly, for the occupiers, experience of common land is quite different from experience of public spaces. Commonizing, according to Linebaugh, "depends on custom, memory, and oral transmission for the maintenance of its norms rather than law, police, and media." ${ }^{14}$ Commoners' experiences of the commons cannot then be organized in public spaces as certain manners and attitudes should be followed under the public eye. The public is composed of private persons. That is to say, going back to the Kantian definition of the public (i.e. people coming together as private persons), the precondition of 'making public' is 'making private' and vice versa. The same can be applied when it comes to physical space, too. While 'dangerous classes' are made into private persons who presumably generated the public, the commons, what had been the common property of the so-called dangerous classes, was turned into private or public property.

\footnotetext{
${ }^{13}$ Neocleous, The Fabrication of Social Order, 2000, p. 38.

${ }^{14}$ Peter Linebaugh, Stop, Thief! The Commons, Enclosures, and Resistance, PM Press, 2014, p. 14.
} 
Marxist scholars tend to analyze commodification as a process of privatization; however, even though commodification is a process of making public (for example, a national park) or making something publicly accessible (such as a piece of art), it is still a process of commodification that remains in opposition to common rights. For example, after engrossing or enclosing common land in the eighteenth century, building wider and more developed public roads between the newly-enclosed lands was not accidental but necessary to provide easy access to the land and transportation of goods. ${ }^{15}$ Yet, once built, these public roads were not commonly organized, used, and maintained. On contrary, they constantly supervised by the governing authorities (who were not necessarily the direct beneficiaries). ${ }^{16}$

Thus, the police project was inherently linked to the making of public and private, so much so that process can be called the making of public and private through policing and vice versa. On the other hand, the making of public and private was never free from resistance by commoners. ${ }^{17}$ In the eighteenth century, resistance to enclosures was mostly a local matter because, as Neeson explains, "commoners saw Parliament itself as part of

\footnotetext{
${ }^{15}$ See Neeson, Commoners, 1993.

${ }^{16}$ Nationalization of land to build public roads, for example, has been one of the main problems for Kurdish guerrilla forces in their current struggle against the Turkish state, indeed one of the reasons why they ended the latest ceasefire. Guerrilla commanders argued that roads and the 'so-called' publicly-used reservoirs in Kurdish cities were built for military purposes. This alone demonstrates how the making of public and public use is inherently a product of police power linking the eighteenth-century enclosure movement to today's so-called war on terror.

${ }^{17}$ Recent cases from Turkey for hydroelectric power plants and from Canada for the XL Pipeline project are exemplary of contemporary enclosures, and the police violence evident in both cases is exemplary of how practices of making public has to go in tandem with policing.
} 
the problem" and therefore kept their opposition local. ${ }^{18}$ This local resistance was met with moral regulations alongside armed attacks, with the definitions of crimes and punishments adjusted accordingly. As Corrigan and Sayer report:

The law used ... to render as crimes what had been customary rights, and to execute, transport or condemn to the hulks those subsequently criminalized. Between 1688 and 1820 the number of capital statutes grew from around 50 to over 200; the vast bulk of the additions concerned offences against property. By 1740 it was a capital offence to steal property worth one shilling. ${ }^{19}$

This was most vividly demonstrated by E.P. Thompson in his inquiry of the Black Act. ${ }^{20}$ Thus, the terms improvement, enclosure, order, security, and police were used as weapons to be mobilized in the war on the commons and commoners.

Neocleous argues that "in bourgeois thought the most significant 'waste' of modernity is the uncultivated land and idle labour that the commons represents." ${ }^{21}$ It is also evident in Colquhoun's remark on commons in 1795: "In short, the Commons of this Country are well known to be the constant resort of footpads and highwaymen, and are literally and proverbially a public nuisance."22 Thus, commons were never considered as part of the public so much as "a public nuisance." Furthermore, as a supporter of

\footnotetext{
${ }^{18}$ Neeson, Commoners, 1993, p. 321.

${ }^{19}$ Corrigan and Sayer, The Great Arch, 1985, p. 98.

${ }^{20}$ E.P. Thompson, Whigs and Hunters: The Origin of the Black Act, New York: Pantheon Books, 1975.

${ }^{21}$ Neocleous, War Power Police Power, 2014, p. 60.

22 Patrick Colquhoun, A Treatise on the Police of Metropolis, 1795, p. 85.
} 
Northampton's enclosure wrote in 1777, "a conviction of [enclosure] being of public Utility" encouraged both Houses of Parliament to act in favour of enclosures. ${ }^{23}$ In other words, what had been a public nuisance when left as it was became a public utility when enclosed and made subject to policing. Accordingly, Neocleous claims that "[t]he belief was that if left unimproved the wasted commons would generate a masterless, idle and disorderly mass, with the consequence that enormous profits were being lost." ${ }^{24}$ This makes it easy to link the war on commons to the question of police. ${ }^{25}$

\section{II. Critiquing Commoners via Police Science}

However, whereas Neocleous limits his discussion on commons and police power to the aspect of capital accumulation, ${ }^{26}$ I would like to explore the enclosure movement as a police project and consider it more broadly than its base-structure aspect. Neocleous begins his argument from capital accumulation and concludes with police power. I would add that the debate on commons also exemplifies how the mode of power in the eighteenth century shifted towards police power while the mode of production shifted towards capitalism - the same shift that Foucault claims to have happened in the reason d'État in the eighteenth century. ${ }^{27}$ In other words, I assume that the modes of power and production

\footnotetext{
${ }^{23}$ Quoted in Neeson, Commoners, 1993, p. 272.

${ }^{24}$ Neocleous, War Power, Police Power, 2014, p. 66.

${ }^{25}$ In that, it should be recognized that, although Neeson, Linebaugh, and Thompson mentioned the issue in their writings, it was Neocleous who first systematically linked it to the broader police studies.

${ }^{26}$ Neocleous, "War on Waste" in War Power, Police Power, 2014, pp. 48-87.

${ }^{27}$ Foucault, The Birth of Biopolitics, 2004, pp. 1-50. It is not my intention to enter the debate on the modes of power here. Nevertheless, it is important to note that the mode of power best fit to the capitalist mode of production is police power, as it emerged in the eighteenth century. However,
} 
accompany and reproduce each other but without either being necessarily and exclusively functional for the other. Such a relation between the two becomes evident in the eighteenthcentury debate on commons. When read along with the police scientists' texts quoted in this thesis, Neeson's well-documented research allows us to demonstrate overlaps between the arguments by defenders of enclosure and police scientists. In what follows, I demonstrate such overlaps and highlight the parts that relate to the project of the public (or the making of public) to demonstrate that the eighteenth-century enclosure of the commons was indeed a police project, or a project in which the terminology of police science was used as a tool box.

Although many Marxist scholars believe that commoners were left alone in their struggle against the enclosure movement of the eighteenth century, this was not the case until the nineteenth century. Neeson documents that, in the eighteenth century, when the war on commons was at its most heated among the emerging bourgeoisie, there were also supporters of commoners, opponents of enclosures, who argued that the commons would provide more benefit for the economy. Neeson reports three main claims: "First, enclosure was for the conversion of arable to pasture; second, it impoverished small farmers and landless commoners who lost land, use rights and work; third, it diminished the supply of military as well as agricultural and manufacturing labour." ${ }^{28}$ Nevertheless, the winners of the published debate were the defenders of enclosure.

its moral and cultural revolution in the form of ideologies like liberalism began as late as the nineteenth century.

${ }^{28}$ Neeson, Commoners, 1993, p. 25. 
During the debate, the truth claims of each side made it clear that there was more to enclosure than accumulation and harnessing idle labour-power. Both sides of the debate argued for the most profitable solution for the nation, yet the one with the better voice and more convincing arguments regarding public utility won the debate. This demonstrates that the war on commons went beyond capital accumulation and expanded to the national interest, the civilizing project, modernity and militarization. This allows us to delve into the problem of base and superstructure in the Marxist model and shifts the question towards truth claims and mode of power.

Although there were two sides to the debate, there was agreement that enclosure would produce a labouring class dependent exclusively on wage labour, and hence end the independence of commoners. For critics of the commons this was a benefit while for supporters it was not. It was a question of whether to approve the change in the conditions of labour or not. The question then, as Neeson puts it, is the following: How did the two sides defend their position, and what was it that enabled the critics to win this debate? In other words, how did they come to argue that wage labour supported a way of life superior to that already supported by free access to land and common rights? ${ }^{29}$

First, critics of the commons favoured modern agricultural techniques over what they labelled 'primitive' or 'barbaric' methods. ${ }^{30}$ They claimed that living in a commonright economy was primitive. As John Clark put it, "[t]he greater production of oats alone would be worth more than all the ancient harvest of mats, rushes, reeds, fish, fowl, fodder

\footnotetext{
${ }^{29}$ Neeson, ibid., pp. 30-34.

${ }^{30}$ Neeson, ibid., p. 30-31.
} 
and fuel." 31 The priority was to produce more with less cost, and modern methods of calculation and predictability would enable the necessary control over production. This situates the problem of commons as a problem of modernity as it was with the science of police. It is also evident in the words of Dr. Richard Price, the Unitarian defender of the American Revolution, who stated in 1771 that "modern policy is, indeed, more favourable to the higher classes of people" and concluded that "the consequences may in time prove that the whole kingdom will consist of only gentry and beggars, or grandees and slaves." 32 First, this makes clear that discussions around the issue acknowledged that enclosure could create a two-class society. Second, the issue was clearly situated as a case of 'modern' policy, not only because of its capitalist function, but also because it relied on modern values of improvement based on calculation and standardization.

Second, critics drew a clear line between the barbaric and the civilized. Common rights were seen as "the barbarous usage of remote ages." ${ }^{33}$ In 1803, the President of the Board of Agriculture, Sir John Sinclair, declared that commons belong to the Dark Ages, when "Men were Strangers to any higher Occupation than those of Hunters and Shepherds." ${ }^{34}$ For this reason, both commons and wastelands were treated as enemies to wage war against, as Neocleous puts it quite well. ${ }^{35}$ The war here, in addition to

\footnotetext{
${ }^{31}$ Neeson, ibid., p. 30.

${ }^{32}$ Neeson, Commoners, 1993, p. 24-25.

${ }^{33}$ John Clark [1813], quoted in Neeson, ibid., p. 30, footnote 45.

${ }^{34}$ Sir John Sinclair, quoted in Neeson, ibid., p. 30.

${ }^{35}$ Neocleous, "War on Waste; or, International Law as Primitive Accumulation" in War Power, Police Power, 2014, pp. 48-87.
} 
Neocleous's argument, was waged to bring civilization to those using such barbaric practices. As already argued by Hunt, and then by Neocleous, policing makes more sense as civilizing process. ${ }^{36}$ Drawing on Nobert Elias's conception of the civilizing process, Hunt argues that, in the nineteenth century, the police functioned as agents of civilizing offensives ${ }^{37}$ However, I think this argument can be expanded backwards to cover police power in the eighteenth century, when civilizing offensives and/or moral regulation projects began to target a specific class of people, the only class from whom that 'precious commodity' of labour could be extracted.

Third, arguments of colonialism were useful for critics in the war against commons since, for them, leaving commons as they were was the same as leaving North America to the Indians. Pennington put this sarcastically in 1769:

Let the poor native Indians (though something more savage than many in the fens) enjoy all their ancient privileges, and cultivate their own country their own way. For 'tis equal pity, notwithstanding some trifling dissimilarity of circumstances, that they should be disturbed. ${ }^{38}$

Pennington also found it strange how, since peopling and cultivating land in North American lands was a national concern, it was possible to "permit large forests, commons

\footnotetext{
${ }^{36}$ See Hunt, "Police and the Regulation of Traffic: Policing as a Civilizing Process?," 2006; and Neocleous, "The Police of Civilisation: War as Civilising Offensive" in War Power, Police Power, 2014, pp. 121-137.

${ }^{37}$ Hunt, "Police and the Regulation of Traffic," 2006, p. 173.

${ }^{38}$ W. Pennington, quoted in Neeson, Commoners, 1993, p. 30.
} 
and open fields in mother country to remain in pretty much the same condition." 39 This should be seen as a form of police power that emerged out of and benefitted from (settler) colonial debates, as clearly discussed in the emerging literature on pacification. ${ }^{40}$

Fourth, both sides focused the debate on 'national interest,' or, "more exactly, and crucially, a debate about what sort of society best served that interest," as Neeson puts it. ${ }^{41}$ For critics, it was well-established that "[c]ommoners in general stood in the way of national economic growth. Instead of the nation's pride they were a measure of its backwardness." 42 As defined in the first chapter, advancing the national interest was one of the central aims of the police project. Thus, enclosure was in the best interests of the nation. It also speaks to the question of change. In that sense, critics of commons were progressives: they wanted to create broader social, political, and economic change through enclosure to 'improve' both agriculture society, and all in the pursuit of happiness and opulence in parallel with police thinking.

Fifth, aside from the arguments deployed in this discussion, there is also the question of military power. Neeson reports that one of arguments of supporters of the commons was that enclosure would diminish military supplies. Police scientists were constantly arguing for the importance of the militia or a standing army as part of their

\footnotetext{
${ }^{39}$ W. Pennington, Reflections on the Various Advantages Resulting from the Draining, Inclosing and Allotting of Large Commons and Common Fields, 1769, London, p. 35.

${ }^{40}$ For colonial roots of the term, pacification, see Neocleous, "War as peace, peace as pacification," Radical Philosophy 159, 2010, pp. 8-17.

${ }^{41}$ Neeson, Commoners, 1993, p. 43 (emphasis is original)

${ }^{42}$ Neeson, ibid., p. 32.
} 
discussion of a new mode of governing. Neocleous states that "central to the development of ideas about liberty, commerce and civil society is the question of military organisation and the relative advantages of militias or standing armies." ${ }^{43}$ According to Neocleous, this concern for military structure reveals the significance of martial virtues for liberal authors of the time, which then relate to capital accumulation, the so-called liberal peace thesis, and the promotion of masculinity over femininity. ${ }^{44}$ Thus, the debate about the commons should also be taken into account in analyzing discussions on military structure by eighteenth-century police scientists since the discussion about militias or professional armies ought to be viewed as a response to the supporters of the commons, who argued that enclosure would diminish population and hence military reserves. ${ }^{45}$

By the end of the eighteenth century, commoners lost the gentry who had supported them. The critics of the commons won the debate and their arguments now shaped the legal system with little opposition. Unsurprisingly, the debate was not won on the basis of the 'best' evidence of improvement but on the basis of politics, 'truth claims' they generated and disseminated. ${ }^{46}$ Ultimately, Neeson says, "the critics' arguments not only legitimized,

\footnotetext{
${ }^{43}$ Neocleous, War Power, Police Power, 2014, p. 92.

${ }^{44}$ Neocleous, ibid., pp. 88-120.

${ }^{45}$ Neeson, Commoners, 1993, p. 39.

${ }^{46}$ Truth games in the sense Foucault defines them: "We are subjected to the production of truth through power and we cannot exercise power except through the production of truth. This is the case for every society, but I believe that in ours the relationship between power, right and truth is organized in a highly specific fashion ... we are forced to produce the truth of power that our society demands, of which it has need, in order to function: we must speak the truth; we are constrained or condemned to confess or to discover the truth. Power never ceases its interrogation, its inquisition, its registration of truth: it institutionalizes, professionalizes and rewards its pursuit ... we are also subjected to truth in the sense in which it is truth that makes the laws, that produces the true discourse which, at least partially, decides, transmits and itself extends upon the effects of power."
} 
but also publicly expressed the terms of class robbery," referring to E. P. Thompson's now famous account. ${ }^{47}$ To conclude, the eighteenth-century enclosure movement was, no doubt, a question of police power. Not only because the land was out of order and needed to be policed but also because the enclosure of commons and wastelands (and engrossment of small plots) caused a radical change that needed to be imposed upon all sectors of society, especially those classes that had benefitted from customary rights.

\section{The Making of the Polis: Governing through Ordering the City}

The most obvious consequence of the massive enclosure movement was the migration of the labour force to the cities in the second half of the eighteenth century. The appearance of 'masterless men and women' in greater numbers than ever in search of reliable food supplies and shelter resulted in an impetus for the ruling classes to find effective means for ordering these new settlers of the cities. ${ }^{48}$ The desirable and forced growth of the urban labour force was accompanied by an undesirable increase in disorder, which came to mean publicly visible poverty, increasing numbers of vagabonds, sudden riots, and the spread of diverse cultural practices throughout the new urban population. "An ongoing anxiety," in Hunt's words,

Foucault, "Two Lectures" in Colin Gordon (ed.) Colin Gordon, Leo Marshall, John Mepham, Kate Soper (trans.), Power/Knowledge: Selected Interviews and Other Writings 1972-1977, New York: Pantheon Books, 1980, p. 93-94.

${ }^{47}$ Neeson, Commoners, 1993, p. 45; Thompson, The Making of the English Working Class, [1963]1991, p. 218: "Enclosure was a plain enough case of class robbery."

${ }^{48}$ See John McMullan, "Social Surveillance and the Rise of the "Police Machine"” in Theoretical Criminology, 2(1), 1998, pp. 93-117. According to McMullan, the dangerousness of the masterless men and women in cities was one of the three consequences related to the changes in early modern England. The other two were the increasing number of vagabonds and the appearance of an illegal underworld. See especially pp. 96-97. 
has beset modernity about the governability of urbanized masses living without any evident structure of rule under conditions where traditional authorities, such as the Church or a visible dominant class, are weakened or no longer present and where class and other forms of deference are fragile. ${ }^{49}$

Hence, the early police scientists, as part of the anxious governing classes, became as much concerned with urban public order as they were with the art of government and national prosperity; the three were in fact tightly linked. If one aspect of this concern for public order is the eighteenth-century obsession with order the other aspect was urbanization, the making of cities; or rather, using the Ancient Greek wording, polis, one can say 'the making of the polis through police science.'

Reflecting the characteristically fetishistic usage of classical Greek during the Enlightenment, almost all police thinkers tended to reference the original meaning of the Ancient Greek term polis, namely city (or the city-state). In this way, the concept of police was understood with reference to city life, or more exactly the administration of the state in tandem with the administration of the city by police scientists. Indeed, in 1765, Boucher d'Argis defined the term police as "the art of providing a comfortable and quiet life to all of the earth's inhabitants, but particularly to city dwellers." ${ }^{50}$ As Foucault confirms, "in the

\footnotetext{
${ }^{49}$ Alan Hunt, Governing Morals: A Social History of Moral Regulation, Cambridge: Cambridge University Press, 1999, pp. 10-11.

${ }^{50}$ Boucher d'Argis, Diderot [1765] quoted in Jean-Paul Brodeur, The Policing Web, 2010, p. 47.
} 
seventeenth and eighteenth century police was thought essentially in terms of the urbanization;" so much so that he claims that "to police and to urbanize is the same thing." 51

It is therefore important to appreciate the line linking police power to enclosure, to the (re)construction of cities, and to public order. Although "the historic cities of Europe today are all older than the state," and although they are historically considered as relatively autonomous administrative entities, this identity of city was slowly altered from the fifteenth century onwards. ${ }^{52}$ In Engin Işın's words, “political and legal thought and State practices sustained a considerable hostility toward the 'old' autonomies practiced by intermediate entities between the State and the 'subject'."53 By the seventeenth and eighteenth century in England, the state had created 'close corporations' of cities, and the city had been placed in the service of the state as an administrative apparatus. Part of the new governmental mentality was governing through cities, with the city becoming an "atom of the State, an indivisible and integral element of governance within the modern State." ${ }^{54}$ By the mid-eighteenth century, urbanizing the rural landscape and population had become part of the dominant mode of power (i.e. police power), complying with the dominant mode of production (i.e. capitalism).

\footnotetext{
${ }^{51}$ Foucault, Security, Territory, Population, 2004, pp. 336 and 337.

${ }^{52}$ Lewis Mumford, quoted in Isin, Cities without Citizens, 1992, p. 17.

${ }^{53}$ Isin, Cities without Citizens, 1992, p. 7.

${ }^{54}$ Isin, Cities without Citizens, 1992, p. 9. Here, the reference to the atom is given with reference to Bentham. It is important to understand how scientific criteria were being applied to governmental discourse and technologies at the time.
} 
On the other hand, cities originally surrounded by walls might well be considered in opposition to the commons and identified with a form of enclosure. Thus, John Horne Tooke, an etymologist of the 1790s, believed that 'the word 'town' derived from AngloSaxon meaning inclosed, encompassed, or shut in." 55 Although early police scientist Sir William Petty's project to build a wall around London to know who and what is inside and outside the city at any given time remained a fantasy, "three great walls," in Linebaugh's words, surrounded London in the late eighteenth century: the wall of Newgate prison (redesigned after its destruction during the Gordon Riots of 1780); the high defensive screen wall of the Bank of England (built in 1796 at the expense of neighbouring residences); and the wall of the London docks. ${ }^{56}$ The walled prison, bank, and port, in a sense, characterized the modern city, representing respectively law and order, money, and commodity, but above all policing as the main mediatory regime for governing people.

It is therefore no surprise that the city, with its markets, residential areas, and specialized commercial zones, might be viewed as a compartmentalized product of enclosure. Thus, the modern city is a reflection of these class terms. As Eick and Briken put it, "[p]olicing the urban setting is about hierarchy, ordering and distribution." 57 Considering that the way cities are organized shapes modern life styles, policing the urban setting is concerned with the regulation target of early modernity. Urbanization is a strictly class phenomenon, requiring an order specific to capital accumulation, the supply chain,

\footnotetext{
${ }^{55}$ Quoted in Linebaugh, Stop, Thief!, p. 25.

${ }^{56}$ Linebaugh, Stop, Thief!, 2014, pp. 26-27.

${ }^{57}$ Eick and Briken, Urban (In)Security, 2013, p. 23.
} 
and production to be reproduced. "Domination of space," says Bourdieu, "is one of the most privileged forms of executing power ..., manipulation of the spatial distribution of groups has always been used to manipulate these very groups." ${ }^{58}$ To add another aspect to Bourdieu's statement, it can be said that the aim of police power as an urbanizing force was to fabricate the kind of communication between the cities' diverse settlers and regulate the existing communication and connections between city dwellers through the use of roads, public squares, highways, and other public spaces. The issue of urbanization and the public, therefore, is strongly related to the question of police and public order.

Donajgrodzki argues that one of the assumptions that led to social police was a social policy aimed at preserving order. Such an aim "must include not only consideration of legal systems, police forces and prisons, but of religion and morality, and of those factors which supported or propagated them-education, socially constructive leisure, even housing and public health." ${ }^{\prime 59}$ Following Kyenemer, Neocleous argues that "the ultimate concern of police was the abolition of disorder." ${ }^{90}$ Yet the question remains: Why did disorder suddenly become a concern as the police scientists and the ruling classes understood it despite having existed for centuries? As the urban population grew larger during the eighteenth century, Emsley argues that "more and more crime and disorder were regarded as things which should not exist in civilized society as it was conceived by the

\footnotetext{
${ }^{58}$ Bourdieu, quoted in Eick and Briken, Urban (In)Security, 2013, p. 265.

${ }^{59}$ A. P. Donajgrodzki, “'Social Police' and the Bureaucratic Elite: A Vision of Order in the Age of Reform" in Donajgrodzki (ed.), Social Control in Nineteenth Century Britain, London: Croom Helm, 1977, p. 52.

${ }^{60}$ Neocleous, The Fabrication of Social Order, 2000, p. 5.
} 
country's rulers. ${ }^{961}$ The emphasis on the civilized society is significant here. As mentioned earlier, the police function is best understood as a civilizing offensive. Honore Antoine Fregier wrote in 1850: "it can be affirmed without fear of contradiction that police is the most solid basis of civilization." ${ }^{2}$ Civilization here, however, means not simply a break with the tradition but a new social order, relying on legal and moral regulations, with the police being precisely the condition of this legalized and moralized civil order. Neocleous suggests that "[t]o order means not only [to] put things in their place, but to rank, grade or class them accordingly." ${ }^{63}$ Disciplining the new settlers of cities according to the modern scientific idealized hierarchy had become the utmost task of police science.

Ordering in this sense was an Enlightenment ideal. Hence, the answer to the question of disorder comes from the modern scientific method, which requires its object of inquiry to be perfect enough to be studied. The obsession with the new scientific method among the Europe's intelligentsia was also pursued in their accounts of moral regulations and popular culture. Anything and everything that was disorderly to the extent that it could not be studied through scientific methods needed to be regulated first. Thus, the eighteenth century witnessed increasing standardization in all areas of life, from language to city design, schooling to religion. Police scientists, on the one hand, needed a perfectly ordered society so that it could become the object of scientific study; on the other hand, states had a new objective: wealth, defined in terms of commodities. Police scientists therefore acted

\footnotetext{
${ }^{61}$ Clive Emsley, The English Police: a political and social history, 1991, pp. 16-17.

${ }^{62}$ Quoted in Pasquino, “Theatrum Politicum,” 1991, p. 108.

${ }^{63}$ Neocleous, The Fabrication of Social Order, 2000, p. 38.
} 
just like Louis Pasteur did in the nineteenth century: they went to society first to collect information, and then went back to their laboratories to study that information, before finally came up with solutions to implement through diverse means, including the police, regulations, and licensing. ${ }^{64}$

These social orderings were ultimately conducted via multifaceted police practices shaped within people's sphere of action and developed as subjectification strategies. That is, police helped inscribe laws and regulations while making people their subjects and carriers. Although the police project was defined from above, it was exercised from below through making working and non-working people its carriers and transmitters. The very principle of police (and modern nation-states for that matter) entails centralized planning and decentralized practice, which highlights the peculiar mediatory position of the police in the socio-political structure of modern societies: while they represent the government and enforce its orders, the institution of police is able to penetrate into the very roots of social relations. So much so, Neocleous argues, that "while as a slogan the rule of law was a rallying cry for the liberal bourgeoisie against the arbitrary power of the ancient regime, its flip side was that it was used to oppose not only arbitrary power from above, but also 'mob rule' from below." 65

As long as the ruling classes knew who they are dealing with, the masses ceased to endanger social order, with commodification being the means for the ruling classes to most

\footnotetext{
${ }^{64}$ See Bruno Latour, "Give me a Laboratory and I will Raise the World" in Science Observed: Perspectives on the Social Study of Science, Karin D. Knorr-Cetina and Michael Mulkay (eds.), London: Sage Publications, 1983, pp. 140-170.

${ }^{65}$ Neocleous, The Fabrication of Social Order, 2000, p. 40.
} 
effectively control the population. Thus, regulations "targeting the manner, time and place in which commodities are consumed" created self-governing bodies ${ }^{66}$ thanks to the monopolization of the means and conditions of production. As long as the ruling classes knew what the labouring classes are producing and consuming, and the limits of that consumption, they ceased to represent a danger. The intent was a fabrication in the full sense of the term, as Neocleous uses it ${ }^{67}$ However, fabrication cannot be the result since political action is full of unintended consequences as opposed to fabrication of work activity, to use Arendtian terms. ${ }^{68}$

The police project did not work as planned without disruption. Among others, there were two unintended consequences of the project. First, the police scientists had imagined that when the population reached a level of "maturity and consciousness," they would increasingly exercise the requirements of good self-governance and act in accordance with the general welfare of all. Starting in the eighteenth century, they attempted to suppress the riots and any other (less visible) disorder permanently. As fascistic as it may seem - at the risk of anachronism - their understanding of order, with its inherent hierarchical discipline, translates into the constant suppression and ongoing oppression methods characterising modern police power. Once people reached a level of maturity or, in other words, once they understood the agenda, this would enable them to exercise their own self-governance

\footnotetext{
${ }^{66}$ Mariana Valverde, "Police Science, British Style: pub licensing and knowledges of urban disorder" in Economy and Society, 32:2, May 2003, p. 237. See also endnote\# 2.

${ }^{67}$ Neocleous, The Fabrication of Social Order, 2000.

${ }^{68}$ See Chapter two, part one of this thesis for the distinction Arendt draws between labour, work, and action.
} 
in an unintended way. It is important, therefore, to stress that the ideal social order of modern police power "cannot exist without constantly revolutionising the instruments of [order] production, and thereby the relations of [order] production, and with them the whole relations of society" ${ }^{\prime 69}$ if we expand Marx's assumptions about the relations of production to the (re)production of order in general. Thus, the police project has had to define and redefine its tools, aims and targets in order to produce and re-produce public order.

The second unintended consequence is that many of the police scientists quoted here shared a humanist comprehension that promoting the population's welfare would be the government's primary aim. This is clearest in the works of German writers like von Justi, von Sonnenfels, and Hegel. Although, for British writers like Petty, Bentham, Colquhoun, and Smith, the main rationale was not humanistic, they nonetheless believed that maintaining the working population's welfare was still necessary in order to make them work more effectively to produce more surplus. Thus, the priority was still the working population's welfare, but in a more circuitous way. Because of the way police scientists defined the ultimate happiness of people (i.e. wealth), governing bodies were at the same time capitalist bodies that comprehended wealth as private wealth, which would allow them to compete with their peers inside and outside their nation state's borders in solidarity with other national wealth holders, which would only inconsequentially increase the prosperity of the working classes as an overall concern.

\footnotetext{
${ }^{69}$ Marx and Engels, Manifesto of the Communist Party, Moscow: Progress Publishers, [1848]1967, p. 38.
} 
As Marx pointed out, capitalist societies aim at "accumulation of wealth at one pole, accumulation of misery, agony of toil, slavery, ignorance, brutality and mental degradation at the opposite pole,"70 while not mixing these two poles. As Thompson demonstrated, the role of police, in this sense, was to maintain public order based on precariousness. ${ }^{71}$ Therefore, in talking about police and security measures one can never assume a monolithic, linear, static thing-in-itself. It is rather a process of diversified tactics exercised unevenly with ruptures, while changing its forms, language, and associates from time to time and space to space. In this sense, the relation between the police and the policed is a contradictory social relation, an arena for struggle. The poor struggled against it, within it, and from time to time for it. Applying Hunt's formulation for moral regulations to police regulations, suggests that police and security involves "some people acting on other people and in doing so acting upon themselves."72

\section{From the Police State to the Public Police: The Birth of the Communication}

\section{Apparatus}

Against such a ruptured background, I address the question of continuity in the police project in this part in order to explore the transition from the late seventeenth to midnineteenth century. Although, starting with the nineteenth century, the broad meaning of the term police became increasingly transformed and narrowed to the embodied uniformed police, it is possible to observe continuity in both the concept and practice of police in

\footnotetext{
${ }^{70}$ Karl Marx, Capital vol. I, [1867], p. 606.

${ }^{71}$ Thompson, The Making of the English Working Class, [1963]1991, p. 84.

${ }^{72}$ Hunt, Governing Morals, 1999, p. 19.
} 
present-day societies. In other words, while the early police concept used to define what the modern state is about, the embodied uniformed police have always been the most important founding and maintaining element, namely the conditio sine qua non of modern nation-states. This is evident from the way that, whenever imperial forces intervene in a modern nation-state, whether in eastern Europe, the Middle East, or north Africa, the first thing they do is to deploy police forces or train those countries' police forces.

As shown in the previous chapter, in the eighteenth century, the term police was common among European scholars. Prussian, Austrian, and Russian civil servants were being taught Polizeiwissenschaft in various universities while French scholars were also familiar with these teachings. ${ }^{73}$ In France, the office of the Lieutenant of Police was first created in 1667 by an edict of Louis XIV. ${ }^{74}$ This was not a new body of men to undertake policing tasks; rather it was an office with a dual purpose: integration of policing duties, in particular in Paris under the divisions of lieutenant civil and lieutenant criminel. This office became a ministry during the revolution and the Napoleonic Empire. In fact the Declaration of the Rights of Man and of the Citizen acknowledged the need for a publicly financed 'police force'. ${ }^{75}$

\footnotetext{
${ }^{73}$ Foucault, “Omnes et Singulatim,” [1979], p. 321.

${ }^{74}$ Brodeur, The Policing Web, 2010, p. 48.

${ }^{75}$ See article 12: The guarantee of the rights of man and of the citizen necessitates a public force: this force is thus instituted for the advantage of all and not for the particular utility of those in whom it is trusted; and article 13: For the maintenance of the public force and for the expenditures of administration, a common contribution is indispensable; it must be equally distributed between all the citizens, according to their ability to pay.
} 
Brodeur mentions two main concerns of the Paris Police in those early years: providing security and maintaining order and control of public opinion. ${ }^{76}$ While the former was provided mainly through the patrol, the latter was provided by preventing the spread of 'dangerous ideas,' censorship of books, ideas, or rumours, preventive custody of potential troublemakers, and protecting working class minds from 'contamination' by the non-working and begging poor. Aside from Brodeur's analysis, it is important to note that, about a century before the revolution, the Paris Police was already obsessed with the nonworking poor. In his memoir on the police of Paris [1779], Lieutenant General Jean Charles Philippe Lenoir claims that "the vilest of occupation is that of beggars; the worst plague for a nation is begging." ${ }^{17} \mathrm{In}$ addition, in the presentation of his memoir Lenoir talks about "tying all individuals to the public order by the 'softest and most artistically fabricated chain' of their common interests and duties." ${ }^{178}$ Shifting attention from the roles and responsibilities of the state to public order and considering how to tie individual subjects to each other as the public is important here. It was the role of the police to create these ties among individuals, with the police regarded as the agents, or rather the mediator of communication between individuals supposedly forming the public. It was Turquot who defined the role of the police as 'communication' in the late seventeenth century, as Foucault reminds us:

\footnotetext{
${ }^{76}$ Brodeur, Policing Web, 2010, p. 53.

${ }^{77}$ Quoted in Brodeur, ibid., p. 54.

${ }^{78}$ Quoted in Brodeur, ibid., p. 56.
} 
As a form of rational intervention wielding political power over men, the role of the police is to supply them with a little extra life—and, by so doing, supply the state with a little extra strength. This is done by controlling 'communication,' that is, the common activities of individuals (work, production, exchange, accommodation). ${ }^{79}$

It seems clear, therefore, that since its beginning, the role of the police was assumed to be providing and controlling communication among the public while constantly forming the masses as the public —often in cooperation with the very same public to be policed.

Under Marquis d'Argenson's leadership, the French Police evolved into high policing between 1697 and 1715. The president of the French Academie at the time, Fontenelle, wrote a eulogy for d'Argenson that laid out the details of his policing. Here, Fontenelle specified that one of the functions of the police chief magistrate is "to be present everywhere without being seen," which Brodeur describes as an early expression of the Benthamian panoptic strategy of surveillance. ${ }^{80}$ The importance of this account is that it shows how concerns about surveillance and its most effective and cheapest technology were already being discussed in the late seventeenth and early eighteenth century on the continent and in England. As Antoine J.M. Servan (1767), Member of Parliament for Grenoble, put it,

\footnotetext{
${ }^{79}$ Foucault, “Omnes et Singulatim,” [1979], p. 319.

${ }^{80}$ Brodeur, Policing Web, 2010, p. 56.
} 
Let us not judge of the [police] magistrate's vigilance by the number of his actions ... A vigilant magistrate is not heavy-handed in using of the law's bridle ... He watches rather than he acts and the more he watches and the less he needs to act. ${ }^{81}$ These concerns were advanced in the studies of the German cameralists, among whom Von Justi's emphasis on the happiness of citizens was understood as "survival, life and improved living. ${ }^{" 82}$ Foucault confirms that Polizeiwissenshaft in Von Justi's writings were not utopian, unlike Turquet, but considered the art of government while simultaneously offering a method for analyzing a population. Nevertheless, for the purpose of this work, the important aspect of these writings is their attempt to orchestrate the kind of public necessary for the well-being, strength, and good government of the state. It thus becomes clear that the concerns of the public and police were intimately related to each other when the modern state and its mode of government were in question in this period. The localized form of this method of researching the population achieved the goal of creating a public that would presumably strengthen the centralized forms of the state. Foucault concludes that the state was simultaneously individualizing and totalizing, and that it would be harmful to place individuals and their interests in opposition to the state and its interests. ${ }^{83}$ I would argue that the project of the public was the best answer to both the individualizing and totalizing tendencies of the modern art of government. As both tactic and target, this was carried out through the project of police.

\footnotetext{
${ }^{81}$ Servan, quoted in Brodeur, Policing Web, 2010, p. 57.

${ }^{82}$ Foucault, “Omnes et Singulatim,” [1979], p. 322.

${ }^{83}$ Foucault, ibid., p. 325.
} 
To clarify, while it is clear from studies of the history of the modern state that political power in European societies has become more and more centralized, specifically as a centralized nation-state, the evolution of an equally important technology of this political power has been more and more local in its practice. This practice we can recognize as the police institution, including its aims and targets. In the same vein, the project of the public operated through both local and central mechanisms. Hunt explains the diverse police responses to diverse public spaces as follows:

police activities interact with other regulatory practices; for example, their capacity to intervene depends in part on the degree of jurisdiction secured by other regulatory agents. If we consider different forms of public space there are significant distinctions between types of public space in which police intervention varies, for example, between the streets (that are subject to only informal and unstable alternative regulation) and university campuses or shopping malls where more formally constituted regulatory regimes are in place. ${ }^{84}$

As Hunt clearly demonstrates in more than one place in his books, the public/private distinction is both a crucial yet always shifting and contested element of modern politics. ${ }^{85}$ Therefore, I insist that, in modern times, private is not necessarily the opposite of public. It becomes clear in police actions concerning the public, as they have always intervened in

\footnotetext{
${ }^{84}$ Alan Hunt, Explorations in Law and Society, 1993, p. 320.

${ }^{85}$ For example, see Hunt, Explorations in Law and Society, 1993 and "Police and the Regulation of Traffic: Policing as a Civilizing Process?" in Markus Dubber and Mariana Valverde (eds.), The New Police Science: Police Powers in Comparative Perspective Stanford University Press: Stanford, 2006, pp.168-84.
} 
the so-called private lives of individuals. Police science and police practices were concerned with the public good, happiness, opulence, prosperity, oeconomy, order, etc. Yet, as Dubber demonstrates, "even in the statistical world of population management according to the principles of police science, police always remained rooted in private householding. $" 86$ From this, one can conclude that the private is not the opposite but the condition of the public.

Paris Magistrate Nicolas de La Mare in his Traite de la Police [1722] defines policing as part of the king's service aiming at the common good; hence he sees it as a branch of public law. According to de La Mare, one of the three meanings of police is the special power of a police magistrate to establish all regulations needed to promote public order in a city. ${ }^{87}$ He identifies eleven elements of urban order that need to be established by the police: religion, morality, public health, food supplies, public roads, bridges and public buildings, public safety, sciences and liberal arts, commerce, factories and mechanical arts, servants and laborers, and the poor. He therefore described the police as having life as their main object: the moral quality of life (as it concerns religion); the preservation of life (as it concerns health and supplies); the conveniences of life (as it concerns trade, factories, workers, the poor, and public order); and life's pleasures (as it concerns the theatre, literature, and other entertainment). In other words, "the police see to the benefits that can be derived only from living in society." ${ }^{88}$ Thus, the object of the police

\footnotetext{
${ }^{86}$ Dubber, The Police Power, 2005, p. 72.

${ }^{87}$ Quoted in Brouder, The Policing Web, 2010, p. 47.

${ }^{88}$ Foucault, “Omnes et Singulatim,” [1979], p. 321.
} 
was to sustain living, but not living for its own sake: the object was to sustain a certain style of living that makes the public, and to sustain the public that makes living.

As I mentioned earlier, seeing to the benefits refers to the role of mediating communication while living in society now refers to the project of forming the public. Such tasks require both individualizing and totalizing strategies as well as simultaneous localized and central apparatuses. It is the so-called 'police state' of the late seventeenth century that paved the way for the 'public police' of the eighteenth century and, increasingly, in the nineteenth century. In this sense, the periodization of the history of police, familiar to both Foucault's and Neocleous's readers, cannot be sketched as clearly as these authors have suggested because police science of the late seventeenth and eighteenth century was concerned with public conscience as much as the (police) state.

In England, in the transition from police as the state to the public police, Patrick Colquhoun played the most important role as the 'architect' or 'inventor' of police. ${ }^{89} \mathrm{By}$ proposing preventing instead of punishing crime as a counter argument to that time's most

\footnotetext{
${ }^{89}$ Peter Linebaugh, The London Hanged: Crime and Civil Society in the Eighteenth Century, London and New York: Verso, 2003, pp. 426-427. Linebaugh gives full credit to Colquhoun, not only for his contribution to the idea of the public police, but also for his role in sketching and strategizing for the class war of the time: "Colquhoun was the London agent for the planters of St Vincent, Nevis, Dominica and the Virgin Islands. He worked tirelessly for the West India Merchants' Committee in London. He worked closely with the Home Secretary and the House of Commons, testifying frequently to the Finance Committee on the subject of police and drafting its legislation on that subject. Edmund Burke, Edward Gibbon and Adam Smith were visitors to his home. He collaborated closely with Jeremy Bentham on police schemes and reformation of the dockyards. If a single individual could be said to have been the planner and theorist of class struggle in the metropolis it would be he. Melville Lee called him the 'architect' of the police. The Webbs called him its 'inventor'. His influence goes far beyond the establishment of the Marine Police Office because his books, although written for the practical purpose of establishing a police force, contain that combination of law, economics, flattery and class hatred that together have exercised a powerful influence upon subsequent conceptions of law and order."
} 
extreme punishment, capital punishment. Colquhoun, referring to Beccaria's teachings, argued that

[t]he only means of securing the peace of Society, and of preventing more atrocious crimes, is, to enforce by lesser punishments, the observance of religious and moral duties: Without this, Laws are but weak Guardians either of the State, or the persons or property of the Subject. ${ }^{90}$

Here 'moral duties' refer to those duties necessary for living together in a society among strangers, i.e. proper public manners. Enforcing such duties is possible under close supervision of the subject, as he declared at the very beginning of his Treatise on the Police of Metropolis:

If the evil is to be cured at all, it must be by the promotion and encouragement of an active principle, under proper superintendence, calculated to prevent every class of dealers, who are known to live partly or wholly by fraud, from pursuing those illegal practices; which nothing but a watchful Police, aided by a correct system of restraints, can possibly effect. ${ }^{91}$

One of the most commonly expressed convictions among police scientists was their opposition to capital punishment. At first sight, it is very difficult to explain this except through their presumably humanist understandings and ties to Enlightenment ideals. When examined more closely, however, it becomes easier to understand their real shared point of

\footnotetext{
${ }^{90}$ Patrick Colquhoun, “A Treatise on the Police of Metropolis," 1795, p. 36.

${ }^{91}$ Patrick Colquhoun, ibid., 1795, p. 13.
} 
opposition to capital punishment. As Linebaugh demonstrated in his brilliant work on eighteenth-century capital punishment in London, "the hangings were functional to the transformation of the wage." ${ }^{92}$ That is, capital punishment was mainly used as a tool to get people to accept the new conditions of wage labour. In their rejection of capital punishment, then, Colquhoun and other police scientists defend life, not for its own sake, but for the sake of wage labour and for the sake of their own way of making wage labour possible through effective policing. Thus, instead of capital punishment, they suggested constant supervision, under which new 'class robbery' could be realized at least more effectively if not necessarily more easily. This, I think answers the question of why all police scientists are strong opponents of capital punishment: those who were charged with the capital punishment were supposedly stealing either the products of their own labour or what was deemed customary at the time. While positioning the new police force in opposition to capital punishment, police scientists were indeed trying to establish a new 'public order' in which the police act as mediators. Making the public out of the dangerous classes was a task the police project inherited from the Enlightenment, and I focus more in the next chapter on the ways in which the working classes were made 'public' through police power.

\footnotetext{
${ }^{92}$ Linebaugh, The London Hanged, 2003, p. 450: "In the seventeenth century witch burnings were characteristic to the reproduction of pure labour power, and in the sixteenth century the extermination of vagabonds and rogues was typical to primitive accumulation, just as in the eighteenth century the hangings were functional to the transformation of the wage."
} 


\section{Conclusion}

In this chapter, I have defined the police project as a component of modern state formation through which the spheres of political, economic, and socio-cultural action were shaped. Starting with the Reformation, the modern era included a dramatic dislocation of the masses from their immediate means of material and cultural subsistence through diverse mechanisms, including tearing them from their commons and common rights for the sake of primitive capital accumulation. This then evolved into privatization and publicization (in the sense of nationalization). This dislocation, then, created a new type of ignorance in the masses, not only in the sense of intellectual ignorance but also in the sense of political, economic, and social ignorance, as they could no longer learn how to manage their conduct without an external mediator. In this way, the role of police took on the role of a (communicative) mediator. The meaning of police has become mediating between the masses and their means of subsistence (that are the means to material, cultural, religious, sanitary, and even linguistic subsistence) by organizing spaces of action, defining limits, expanding opportunities, controlling distribution, reinforcing production, securing communication, etc.

The broader project of police scientists in the eighteenth century was to define, analyze, and solve the problems of this transitional society, changing from a social order in which people had immediate access to their means of subsistence to a new social order in which people needed to be informed about the ways of all kinds of conduct that make them alive as material, social, and political beings. These mediators shaped the experience of social, economic, and political conduct. In this sense, police power had both positive 
and negative effects, emanating from its Enlightenment ideal: empowering people by making them part of the public while revoking their capacity to organize effectively based on their diverse experiences. If the lion's share falls to the middleman, as Marx notes below, then our inquiry should start from this great mediator, i.e. police:

in all spheres of social life the lion's share falls to the middleman. In the economic domain, for example, financiers, stock-exchange speculators, merchants, shopkeepers skim the cream; in questions of litigation the lawyer fleeces his clients; in politics the representative is more important than the voters, the minister more important than the sovereign; in religion, God is pushed into the background by the "mediator," and the latter is again shoved back by the priests, who are the inevitable mediators between the good shepherd and his flock. ${ }^{93}$

Despite being over a century in the making, the fabrication of a public, understood as strangers coming together in an urban setting on the subjects concerning everybody, slowly but surely became a central concern of the eighteenth-century ruling classes.${ }^{94}$ On the other hand, the public understood as the spaces and things used commonly emerged as a new concept, slowly replacing the term the commons. The concern for the public that accompanied the police project while the greater police ideal turned into the police force can now be understood by referring to three main issues of the time: enclosure, civilization,

\footnotetext{
${ }^{93}$ Karl Marx, Capital, vol. I, p. 907 (footnote number 3).

${ }^{94}$ Although on the part of the working classes, being around strangers might not refer to a similar anxiety. Eighteenth and nineteenth century cities might not necessarily have been a place of strangers as kinship and fellow countryman/woman relations were more common than both governing authorities' and historians' expectations. See David Cressy, "Kinship and Kin Interaction in Early Modern England," Past and Present 113, 1986.
} 
and urbanization. I will continue to address this question of modernity and capitalism throughout the thesis. Here, it suffices to say that this distinctly modern trivet can easily be explained by reference to the three main components of capitalism: constant primitive accumulation, exploitation of labour, and the security of the supply chain (distribution and consumption). 


\section{CHAPTER FIVE}

\section{(RE-)CLAIMING THE PROLETARIAN PUBLICS}

Labour is absolutely requisite to the existence of all Governments; and as it is from the poor only that labour can be expected, so far from being an evil, they become, under proper regulations, an advantage to every country, and highly deserve the fostering care of every government.

Patrick Colquhoun, The Police of the Metropolis, 1795

Building on the link defined in the previous chapter between the projects of the public, police, and enclosure, in this chapter I explore the question of the proletarian public sphere, or the ways in which "the fostering care of every government," in Colquhoun's words above, have worked on the everyday life experiences of the working and nonworking poor. The term, proletarian public sphere, which I borrow from Negt and Kluge, has been barely used or linked to broader studies on modern law and order. Hence, part of the aim of this chapter is to help historicize the term and locate it in the literature on social control and policing of the working and non-working poor with the reminder of $\mathrm{E}$. P. Thompson in mind about "terms sometimes so hard and objective-seeming (as with Althusser's 'repressive' and 'ideological state apparatus') that they disguise the fact that they are still metaphors which offer to congeal a fluent social process." ${ }^{1}$ The proletarian

1 E.P. Thompson, "Eighteenth-century English society: class struggle without class?" Social History 3:2, 1978, pp. 133-165, p. 152. 
public is still a metaphor, and one I hope to construct as a useful one to understand the historical material connections between the categories of class, the public sphere, police, and politics.

In the first part of the chapter, I discuss some challenges and possibilities regarding the conceptualization of the proletarian public spheres, focusing on two arguments. First, modern police power emerging in the eighteenth century is inherent in the formation of any kind of publics, including the proletarian publics. Second, modern history is a history of the constant, simultaneous formation, deformation, and reformation of the relatively autonomous proletarian publics. These processes have been also the processes in which agents (e.g. the police among others) and targets (e.g. the working poor among others) of police power have been at play, shaping each other's sphere of action through mutual domination and subjugation. In arguing so, my claims to universality of the proletarian publics in capitalist societies relies not on the case of London, England as if this case can be expanded to the world of capitalism, but on the structural consequences of the capitalist mode of production based on extraction of surplus value. Having said so, I do not reject the specificities of proletarian publics in different times and places.

In the second part, I look at the case of London in the late eighteenth and early nineteenth century to explore the formation of the proletarian publics with the earlier definition of working classes. I examine the ruling classes' attempt to turn these 'dangerous classes' into the public. In the third part, I focus my attention on the Police of the River Thames, and the London Metropolitan Police as they were projected, actualized, and reported on by Patrick Colquhoun. My primary focus here is the civilizing offensives (or 
moral regulation) in shaping the public and its spheres. In the last part of the chapter, I question the revolutionary potential of proletarian publics. Taking penny papers and workers' societies as examples, I attempt to demonstrate (1) relative autonomy of the proletarian publics; (2) the ways in which the experiences of the working poor were organized; and (3) the type of solidarity that emerged out of these experiences. Drawing on the expectations from the so-called commons today within the emerging socialist literature, I conclude by suggesting that instead of the commons the proletariat's claim to the public should be in focus.

\section{Conceptualizing the Proletarian Publics}

While Negt and Kluge attempt to develop a theory that takes into account the proletariat's agency in shaping their own mode of life, some of their proposed categories cannot go beyond the deterministic fallacies of classical Marxism. ${ }^{2}$ Their use of the category working class as a somewhat homogeneous unity, of the term 'class interest' as pre-determined 'thing,' of proletarian experience as a monolithic, one-sided category, and the distinction they make between 'real' and 'unreal' experience/people/context of life/interests limit their conceptualization for a socio-historical analysis. Therefore, I suggest, their terminology needs to be amended in order to explore the historicity of the proletarian public spheres. I aim to open up a discussion on the definition of the term proletarian public sphere and differentiate its usage from that of its inventors to make it

${ }^{2}$ Oscar Negt and Alexandre Kluge, Public Sphere and Experience: Towards an Analysis of the Bourgeois and Proletarian Public Sphere, Peter Labanyi, Jamie Owen Daniel, and Assenka Oksiloff (Trans.), Minneapolis and London: University of Minnesota Press, [1972] 1993. 
more open to socio-historical analysis and to the analysis of police power. In doing so, I first draw on a Gramscian conception of politics, common sense, and (counter-)hegemony, as well as a Foucauldian understanding of the modes of subjectivization, to define the proletarian publics in relation to proletarian experience. Then, drawing on the discussions of the previous chapters, I highlight the relation between police power and the formation, deformation, and reformation of the proletarian public at a theoretical level.

Before doing so, I should elaborate on my preference here for the adjective 'proletarian.' According to Samuel Johnson's Dictionary of the English Language published in 1755-most commonly used until the first publication of the Oxford English Dictionary in 1928 - proletarian referred to "the lowest of the low-whoever was 'mean, wretched, vile, or vulgar'."3 According to Linebaugh, the invention of the word was "the counter-revolution of a class that went to Roman history to find a term adequate to express its contempt (and fear) of those 'lawless' or 'loose and disorderly' persons whom it had just vanquished." ${ }^{4}$ The name they found was different to the name they called labourers in the previous mode of production, i.e. plebeian, a working class of limited property according to the Roman constitution whereas proletarian referred to a class that is good for nothing except the production of workers or the women's labour of giving birth. Thus, proletarian was a new term that marked the beginning of a new historical term with a new mode of production relying on property-less workers who were also feminized at a

\footnotetext{
${ }^{3}$ Quoted in Peter Linebaugh, The London Hanged: Crime and Civil Society in the Eighteenth Century, London and New York: Verso, 2003, p. 122.

${ }^{4}$ Linebaugh, The London Hanged, p. 121.
} 
discursive level to be further underestimated while a new type of patriarchy was on the way. ${ }^{5}$ It is thus interesting to note that 'the appearance of 'proletarian' in the English vocabulary corresponds to the simultaneous discovery of 'the labour theory of value.",6

Within the scope of this thesis, I do not necessarily refer to the working poor when I use the term proletariat. Rather, I use it to include both the working and non-working poor, and both the lumpen and non-lumpen proletariat, to use the terms of classical Marxism, ${ }^{7}$ because all segments of the class, although proportionally, contribute to the formation of proletarian publics. My intention in insisting on the term proletariat is to raise the revolutionary potential of the term itself as it creates a counterhegemonic standpoint at the discursive level by revealing the mystery over the somewhat more hygienic terminology of the working class. In coining the term proletarian public sphere, I try to understand class as a historical category, not so much because we can identify in history isolated cases of class-based actions, in this case proletarian actions, but precisely because

\footnotetext{
${ }^{5}$ Marxist feminists have made the case for the peculiarity of capitalist patriarchy for many years now. The main source on the topic being Zillah Eisenstein's edited volume, Capitalist Patriarchy and the Case for Socialist Feminism, Monthly Review Press, 1979.

${ }^{6}$ Linebaugh, The London Hanged, p. 121.

${ }^{7}$ Although I think 'lumpen proletariat' is overly used within classical Marxist literature with no significant contribution to the class analysis because it is a rather exaggerated category arising from Marx's rather contextualized analysis of France. Nevertheless, Marx defines the lumpen proletariat, which he almost always mentions in italics, as follows: "in all big towns forms a mass sharply differentiated from the industrial proletariat, a recruiting ground for thieves and criminals of all kinds living on the crumbs of society, people without a definite trade, vagabonds, gens sans feu et sans aveu [men without hearth or home], varying according to the degree of civilization of the nation to which they belong, but never renouncing their lazzaroni character." Karl Marx, The Class Struggle in France, 1848 to 1850.
} 
class indicates a way of life that can be "derived from the observation of the social process over time,", as E.P. Thompson explains:

Class eventuates as men and women live their productive relations, and as they experience their determinate situations, within 'the ensemble of the social relations,' with their inherited culture and expectations, and as they handle these experiences in cultural ways ... No actual class formation in history is any truer or more real than any other, and class defines itself as, in fact, it eventuates. ${ }^{9}$

Thus, the eventualization of class ways of action can be observed through the publics: those spheres of action where people "who share the same congeries of interests, social experiences, traditions and value-system, who have a disposition to behave as a class, to define themselves in their actions and in their consciousness in relation to other groups of people in class ways" act politically. ${ }^{10}$

For Gramsci, politics is never a sphere of already-determined forms of struggle among the unitary subjects of history; rather, it is a sphere, Hall stresses, "where forces and relations, in the economy, in society, in culture, have to be actively worked on to produce particular forms of power, forms of domination." ${ }^{11}$ Politics and the public sphere, in this sense, depend on the relations of productive forces at any particular moment. Such a

${ }^{8}$ E.P. Thompson, "Eighteenth-century English society: class struggle without class?" Social History 3:2, 1978, 133-165, p. 147 (emphasis is original).

${ }^{9}$ Thompson, ibid., p. 150 (emphases are original).

${ }^{10}$ E. P. Thompson, "The Peculiarities of the English," The Socialist Register 2, 1965, pp. 311-362, p. 357 (emphases are original).

${ }^{11}$ Stuart Hall, "Gramsci and Us,” Marxism Today, June 1987, pp. 16-21, p. 20. 
definition of politics makes it possible to understand the ways in which the particular lived experiences of the proletariat constitute a counterhegemonic potential that can oppose the domination of/within the bourgeois and market public spheres. Such an understanding of politics does not negate the mutual existence of counter forces; that is, the proletarian public being the dialectical opposite of the bourgeois public. Yet, at the same time, it does not deny that counter forces do exist within the proletarian publics in the form of diverse subjectivization practices. The possibility of counter hegemony (rather than antihegemony) lies at the very existence of the proletarian publics. Ultimately, as Stuart Hall puts it:

Hegemony could not be reduced to economic domination alone, but required the reshaping of civil, political, intellectual and ethical life in line with the general tendencies and direction of the whole social formation. This made the role of the state in 'winning consent' to this enlarged social leadership a pivotal issue. ${ }^{12}$

In the process of forming historic blocks as foundations for rule, organic intellectuals create this consent through language, moral regulations, popular culture, and coercion. Once mediated through these "cultural institutional processes, hegemony in its most integral form can congeal in people's subjectivities and moralities ... and their contradictory forms of consciousness that may be hostile to and compatible with bourgeois world view." ${ }^{13}$ One

\footnotetext{
${ }^{12}$ Stuart Hall and Phil Scraton, "Law, Class, and Control" in Mike Fitzgerald, Gregor McLennan, Jennie Pawson (Eds.) Crime and Society: Readings in History and Theory, London: Routledge, 1981, p. 480.

${ }^{13}$ Stefan Kipfer, "Urbanization, Everyday Life and the Survival of Capitalism: Lefebvre, Gramsci and the Problematic of Hegemony," Capitalism, Nature, Socialism 13:2, June 2002.
} 
of the key achievements of organic intellectuals in the Scottish Enlightenment was to integrate a recognition of different ruling groups in the historic block under the name of 'The Public,' involving also the laboring classes as it refers to the 'political nation.' In the words of Philip Corrigan and Derek Sayer,

[i]nternally to the ruling historic bloc there are orders of status and etiquette, those acting observe one another closely. Externally, for the ruled, there are the spectacles of terror and patronage, punishment and benevolence, along with that form of localized 'natural policing' that allowed the surveillance of this social audience from those on the stage. ${ }^{14}$

As Warner claims, however, the public in bourgeois societies is bourgeois "not just because its members are mostly bourgeois but also because the reorganization of society around the institutions of public criticism was one of the means by which bourgeois society came into being, conscious of itself as 'society'." 15 Accordingly, two points should be made clear: first, the notion of the public sphere is specific to bourgeois societies; second, the public of the bourgeois society necessarily encompasses the proletariat as well. How then to differentiate the proletarian publics from the bourgeois ones? First, we should acknowledge that the publics of the proletariat eventuate as the proletariat as a class eventuates. Yet there are some components that remain the same as a result of structural consequences of the

\footnotetext{
14 Philip Corrigan and Derek Sayer, The Great Arch: English State Formation as Cultural Revolution, Oxford: Basil Blackwell Ltd, 1985, pp. 106-107.

${ }^{15}$ Warner, Publics and Counterpublics, New York: Zone Books, 2005, p. 48.
} 
capitalist mode of production, and I believe that one can rely on these in theorizing the proletarian publics. I list ten characteristics below to illustrate:

First. As I emphasized earlier, diverse public spheres stand in dialectical relation to each other under capitalism, and they often share the same space while mutually shaping each other's sphere of impact. In this thesis, my focus is the bourgeois, proletarian, and market publics. Such mutuality among these three should not be considered as if they have separate spatial and temporal fields. On the contrary, they relate to each other by creating each other's counter sphere from within. Therefore, the proletarian publics are never free from the bourgeois ones. For example, we cannot call all public houses, or pubs, in early nineteenth-century London proletarian public spheres as they belong, by being means of trade, to the market publics, and are under the influence of the bourgeois publics through being regulated by the rules and regulations of the government. Only if these places are attended by workers to do business regarding their class interests or class ways of actions can we call them proletarian publics, and only then do they become worth looking at while studying the subject of the proletarian publics.

Second. We can only talk about relative autonomy of the proletarian publics and never hegemonic proletarian publics. Relative autonomy, in the sense of its content and function, is the condition for a proletarian public. That is also to say that it might be temporary or permanent, physical or discursive, material or immaterial, tangible or intangible.

Third. For Negt and Kluge, the organization of the horizon of collective experience is the defining feature of a public sphere, rather than the institutions and procedures we have come to identify with this notion. Their main concern is the ways in which, the means by 
which, the mechanism through which the social horizon of experience is constructed. ${ }^{16}$ Here, experience (Erfahrung) is understood as mediated experience in its Hegelian sense, which becomes meaningful in a dialectical process. Proletarian public spheres must therefore turn immediate experience into mediated and transformative experience.

Fourth. The lived experiences of productive forces are organized differently but not independently from that of the bourgeoisie. The proletariat's subjectivity and field of action are shaped by the attempts of the ruling bourgeoisie to fabricate a social order. At this point, Foucault's understanding of subjectivization practices helps explain how bourgeois hegemony congeals in the proletariat's subjectivities and moralities. According to Foucault, there are three modes of objectification that transform human beings into subjects: the modes of inquiry that try to give themselves the status of sciences; the objectivizing of the subject in 'dividing practices'—subjects are either divided within themselves or divided from others; and the way human beings turns themselves into subjects. ${ }^{17}$ Looking at the proletarian publics means then looking at the ways in which the proletariat was made the subject of the bourgeois public spheres-starting in the mideighteenth century — through the projects of police and the public, how the subjectivity of the proletariat reformed and established the proletarian publics as counterhegemonic camps, and how subjectivization practices in the projects of police and the public deformed and reformed the proletarian publics to make them comply with the bourgeois publics.

\footnotetext{
${ }^{16}$ See Miriam Hansen, "Foreword,” Negt and Kluge, Public Sphere and Experiecne, p. x.

${ }^{17}$ Michel Foucault, "The Subject and Power" in Essential Works of Foucault 1954-1984 vol. III, Power, Robert Hurley and others (trans.), James D. Faubion (ed.), New York: The New Press, 2000, pp. 326-327.
} 
Fifth. In a way, Alan Hunt's formulation for projects of moral regulation can be applied to the projects of police and the public as both largely encompass projects of moral regulation: "Projects of moral regulation and ethical self-formation frequently come together in the complex and varied forms of interaction between governing others and governing the self." 18 In this sense, the proletariat can be thought of as a class that is in the making both from within, through the organizational capacities of those who compose the class, and from outside, through the dividing practices of the bourgeoisie and their attempts to homogenize quite diverse communities of the working and non-working poor. It seems interesting how J. M. Neeson repeatedly notes that both defenders and critics of the commons ignored or excluded the commoners themselves from public debate while both sides argued over deciding their future. ${ }^{19}$ Similarly, in discussions over the working and non-working poor, one can observe the same subjectivization practices as part of governing others and governing the self.

Sixth. I should immediately note that the proletarian public defined here is different from what is widely referred to as counterpublics in the literature, which Warner defines as follows:

it maintains at some level, conscious or not, an awareness of its subordinate status ... it is usually related to a subculture, but there are important differences between these concepts. A counterpublic, against the background of the public sphere,

\footnotetext{
18 Hunt, Governing Morals: A Social History of Moral Regulation, Cambridge: Cambridge University Press, 1999, p. 16.

${ }^{19}$ J. M. Neeson, Commoners: Common Right, Enclosure and Social Change in England 1700-1820, Cambridge University Press, 1993, p. 52.
} 
enables a horizon of opinion and exchange; its exchanges remain distinct from authority and can have a critical relation to power; its extent is in principle indefinite, because it is not based on a precise demography but mediated by print, theatre, diffuse networks of talk, commerce, and the like. ${ }^{20}$

This definition can also be linked to Nancy Fraser's definition of the 'subaltern counterpublics,' according to which 'members of subordinated social groups-women, workers, peoples of color, and gays and lesbians — have repeatedly found it advantageous to constitute alternative publics." ${ }^{21}$ I take issue with two things in both definitions: one is the reference to subculture, and the other is the claim that counterpublics exist against the background of the public sphere (meaning staying within the same bourgeois public sphere). First, I do not conceptualize the working and non-working proletariat as a 'subculture' or 'social group,' nor do I include women (half of the population), racialized populations, or sexual minorities within a category as such. To me, these classifications are all the structural consequences of bourgeois societies so they cannot be 'sub-' to anything; rather, they are the main targets of hegemonic power and hence the main cultures determining the ingredients of the counter-revolutionary popular culture. Therefore, they should be treated theoretically as such. Second, I argue that the publics are created within the bourgeois public sphere, not necessarily against its background but rather in dialectical opposition to its very existence. In that they are not 'alternatives' per se because, rather

\footnotetext{
${ }^{20}$ Warner, Publics and Counterpublics, 2005, p. 56.

${ }^{21}$ Nancy Fraser, "Rethinking the Public Sphere: A Contribution to the Critique of Actually Existing Democracy," Social Text 25/26, 1990, pp. 56-80, p. 67.
} 
than creating an alternative to the bourgeois public sphere, a genuine revolutionary movement should aim to demolish it from within since the public sphere relies on a common sense provided by ideology. One cannot praise the notion of the public sphere without acknowledging that the notion of 'public opinion' has any value. Calling it an ideological construction does not suffice as it lies at the heart of the notion of the public sphere. As Negt and Kluge note very clearly, it is the job of capitalism to work towards such a construction: 'Capitalism must 'dirty its hands' by dealing with human beings. This is the reason for its extreme instability."22

Seventh. It should be recognized that the experience of the proletariat and how it is organized in the public sphere should be understood without using mainstream conceptual tools. In the case of the proletariat, for example, we cannot talk about privacy or a private life of one's own in opposition to the public. The privacy of the poor has never been a concern of state institutions. Instead, the proletariat has had to earn its privacy when needed. It is through this struggle for 'privacy' that the relatively autonomous organization of the proletarian publics has been possible. Otherwise, the mainstream meaning of privacy meant nothing more for the proletariat than the secrecy of poverty, misery, oppression, and exploitation. At this point, it might be more useful to look at feminist arguments to see the parallels. Catharine MacKinnon, for example, explains why feminism sees the personal as political:

\footnotetext{
${ }^{22}$ Negt and Kluge, Public Sphere and Experience, p. 309.
} 
For women the measure of intimacy has been the measure of the oppression. This is why feminism has had to explode the private. This is why feminism has seen the personal as the political. The private is the public for those for whom the personal is the political. In this sense, there is no private, either normatively or empirically. ${ }^{23}$

Would it be possible to say the same for the proletariat? I would say 'yes' for at least two reasons: first, what is deemed private, namely, the economy, is in fact not private because it involves the publicly exploited labour power of the proletariat, who can live only through making their labour power publicly available; second, what is supposedly said to be incarnated in private households - the manners, attitudes, and morals of the proletariatactually make the public comply with bourgeois ideals. It is only through exposing what is private to the public gaze, socializing with private memories, opinions, morals and so on, that we can re-define and re-build the public. In that sense, I am referring to the oppression, domination, and exploitation that is excluded from the hierarchy of human subjects deemed suitable for public discussion: disability, aging, ethnicity, income level, and so on. Only insofar as these do not define one's personal issues can we celebrate them.

Eight. I define the public sphere as a condition of communication, not its medium. That is, the condition-public has also been conditioned to the extent that it has come into contact with certain regulations, objects, supervisions, and so on. As the dominant mode of power, police power is inherent in the formation of any type of public. The working class as a public was created from above, by police power, which identified it, surrounded it with

\footnotetext{
${ }^{23}$ Quoted in Warner, Publics and Counterpublics, p. 33.
} 
discourse, gave it as attributes like idle, the working poor, the respectable classes, and constructed it through non-discursive institutionalized police action. In the following sections, I exemplify this through the case of the River Thames Police to show how Colquhoun defined a proletarian public from above.

Ninth. As John Foster remarks, "liberalization was in fact a collective ruling-class response to a social system in crisis and integrally related to a preceding period of working-class consciousness. ${ }^{24}$ In the same vein, early liberals or, more specifically, those widely accepted as the founding 'fathers' of liberalism, were indeed tirelessly arguing against popular democracy based on the claim that it would destroy the foundations of good trade and relations of production. Thomas Rainsborough, the leading spokesman for the Levellers summarized the feeling at the time bluntly: "Either poverty must use democracy to destroy the power of property, or property in fear of poverty will destroy democracy." 25 Nevertheless, it ultimately needs to be accepted that liberalization under capitalism meant freeing morals from previous moral ideals to replace them with new ones complying with capitalist accumulation. Thus, liberalization, representative democracy, and their conditio sine qua non, the bourgeois public sphere (as a sphere of political action for everybody), were means to dominate the movements of the proletariat that had emerged out of the relatively autonomous proletarian public spheres.

Tenth. The nineteenth century became one when the ruling classes implemented a

\footnotetext{
${ }^{24}$ John Foster, Class Struggle and the Industrial Revolution: Early Industrial Capitalism in Three English Towns, London: Methuen \& Co Ltd, 1974, p. 3.

${ }^{25}$ Quoted in Linebaugh, The London Hanged, p. 121.
} 
'renovation of morals' in the name of 'prevention of crimes.' As Hall puts it bluntly,

Criminalization is a particularly powerful weapon ... because it mobilizes considerable popular approval and legitimacy behind the state. People are more likely to support state action against a criminal act than they would the use of the law to repress a political cause ... Criminalization not only emphasises, but exaggerates, the degree of violence involved, at the expense of political motives ... Focusing on the violence makes it easier to mobilize popular support for a measure of containment. ${ }^{26}$

This can be used to explain how proletarian publics are at the risk of being criminalized, and how the public cannot exist without the police as it requires constant criminalization and definition of what is acceptable and what is not.

To be sure, bourgeois society is structured around hierarchical power relations based on categories of class, ethnicity, 'race', gender, age, ability, and so on. The political endeavour of the ruling classes is therefore nothing more than normalizing and rendering natural " $[\mathrm{w}]$ hat are in fact ontological and epistemological premises of a particular and historical form of social order" while making what is obvious to the great majority of masses mysterious through what Corrigan and Sayer call "moral regulation." 27 To this, I would add that the main target of moral regulation was the public and its sphere in order to form, deform, and reform the publics to legitimize inequalities and police the less

\footnotetext{
${ }^{26}$ Stuart Hall and and Phil Scraton, "Law, Class, and Control" in Mike Fitzgerald, Gregor McLennan, Jennie Pawson (Eds.) Crime and Society: Readings in History and Theory, Routledge, 1981, pp. 488-490.

${ }^{27}$ Corrigan and Sayer, The Great Arch, p. 4.
} 
advantaged in these hierarchical power relations into the orientation of their stations in the public. Establishing the essential elements of the relations of the new mode of production required consistent intervention in the lives of people as individuals in the form of supervision, control, and ordering, namely, policing.

\section{The Formation of the Proletarian Publics and Police Power}

The eighteenth century was defined by an acceleration in the amount of 'free' labour, separating the means of subsistence from the immediate reach of the labourer, thereby 'making labour power a commodity.' The emergence of labour as a power within the hierarchies of other power relations specific to 'modern society' in the making required new measures to exert control over or fight back against this new 'labour power.' This need became clearest after the first shocks of the French Revolution, as Thompson explains: "most men and women of property felt the necessity for putting the houses of the poor in order." ${ }^{28}$ While the process was already underway, the counter-revolutionary panic of the ruling classes after the French Revolution turned this into projects with strategies to be implemented more severely with newer and more effective tactics. It was a war against labour power, not to defeat it but to pacify and integrate it into the power of the nation. More clearly it was an overt example of class warfare.

Referring to this counter-revolutionary panic and the emerging class consciousness, Thompson calls the period between 1790 and 1850 the "English Revolution." 29 Thomas

\footnotetext{
${ }^{28}$ Thompson, The Making of the English Working Class, p. 60.

${ }^{29}$ Thompson, ibid., pp. 111-120.
} 
Paine published The Rights of Man in 1791 in response to counter-revolutionary Edmund Burke's Reflections on the French Revolution, published in 1790. It was distributed widely, with Paine becoming a household name during the year after its publication. ${ }^{30}$ According to Thompson, "the outlawry of Paine (and the banning of The Rights of Man) signaled the opening of an era of repression," 31 with class warfare openly declared. In his "Thoughts and Details on Scarcity" (1795), Burke recommends offering labourers no more than "[p]atience, labour, sobriety, frugality and religion," while the period between 1790 and 1850 saw a variety of working class struggles. To name just a few: the English Jacobins between 1790-1799, ${ }^{32}$ the Luddite Crisis (1811-1813), The Pentridge Rising in 1817; the Peterloo Massacre in 1819, the beginning of trade union activities, Owenite propaganda, radical journalism, and the Ten Hours Movement emerged between 1819-1829, the revolutionary crisis of 1831 and 1832, and Chartism between 1837 and 1848 .

This was also apparent from the counter-revolutionary panic of the ruling classes. Seeing trade unionism, education, and working class sports, along with publications and societies demanding political rights led them to become the opponent in the war. Signals of this panic were numerous: posting spies in popular societies, promoting anti-Jacobin societies, Sunday schools (which, having started in 1751, became common by 1784), and

\footnotetext{
${ }^{30}$ Thompson, ibid., p. 121.

31 Thompson, ibid., p. 121.

32 The Society for Constitutional Information was founded in 1780 with the objective of, in Major Cartwright's words, one its founders: "to give Constitutional Information to the public, particularly, and expressly, for the purpose of promoting a parliamentary reform for the recovery of their lost rights." See Carl B. Cone, The English Jacobins: reformers in late 18th century England, New Brunswick and London: Transaction Publishers, 2010 [1968], p. 60.
} 
informative tracts targeting the working classes (e.g. Hannah More's schools and halfpenny tracts between 1795 and 1833), the rise of Methodists between 1760 and 1802, the establishment of the Society for Bettering the Conditions of the Poor (1796), The Vice Society (1802), and Colquhoun's River Thames Police (operating between 1798 and 1800, first with funds from the West Indian Merchants, then with public funding). They targeted the proletarian publics, gathering places, means of communication, and means of creating discourse production. One example is particularly enlightening. In 1792, 186 pub owners in Manchester signed a declaration refusing the use of their rooms by "any CLUB or societies ... that have a tendency to put in force what those INFERNALS ... wish for, namely, the DESTRUCTION OF THIS COUNTRY," ${ }^{33}$ while owners who did not sign were threatened and forced to.

By 1809 , the ruling class was mostly satisfied that overt Jacobinism was no longer a danger, although moral indiscipline remained a threat. Since the Reformation, the secularization of moral regulation had accelerated, ${ }^{34}$ and it can be argued that this enabled the means, targets, and strategies of moralization to spread into every aspect of public life. The official disciplinary agencies in the mills, churches, schools, magistrates, and military were, for example, supplemented by quasi-official agencies of friendly societies, newspapers, and so on, to enforce acceptable moral conduct in the public. ${ }^{35}$ Their target was less the undisciplined than those who were already disciplined differently. The ruling

\footnotetext{
${ }^{33}$ Thompson, The Making of the English Working Class, p. 124.

${ }^{34}$ Hunt, Governance of the Consuming Passions, 1996, pp. 273-295.

${ }^{35}$ Thompson, The Making of the English Working Class, p. 442.
} 
classes strategized that by identifying them and giving them responsibility, they could help moralize and discipline the undisciplined.

Although this process of social disciplining was not uncontested, the disciplinarians largely won the battle. However, their true victory was not to end the battle but to turn it into continuous war as they constructed the public sphere as a battlefield or, better, as the Kampfplatz in which both ideas and actions could struggle for the benefit of the powerful. A bourgeois public sphere was created through "moralization of the poor and their culture in an attempt to discipline an 'unruly' and 'uncivilized' popular autonomy." 36 This autonomy was controlled through the making of the public sphere. By 1830, Thompson observes, “'average' English working men became more disciplined, more subject to the productive tempo of 'the clock,' more reserved and methodical, less violent and less spontaneous." ${ }^{37}$ This was a result of defining and building from above the proletarian publics as the public. The bourgeois public sphere might have been a battlefield, but it was only tied to the condition of the proletarian publics losing their public relevance and becoming merely fields of necessities. The physical and discursive spaces where the proletariat came together to share experiences were redefined as apolitical or non-political spaces of necessities.

In this attempt, the ruling classes benefitted from the modern police power enforced by the new, uniformed police. Below, I explore the coming of the new police as an attempt

\footnotetext{
${ }^{36}$ Hunt, Governance of the Consuming Passions, pp. 273-295.

${ }^{37}$ Thompson, The Making of the English Working Class, p. 451.
} 
to define the proletarian publics from above. I then explore the attempts of the proletariat to define their own publics in resistance to these moralizing offensives. It was crucial to make the public out of the proletariat because only the public, not (civil) society nor community, can be an addressee, or a responsible, accountable subject under the bourgeois social order. The public may have been given various meanings, but one is certain: it always exclusively refers to an identified addressee, possessing opinions to affect decision-making processes, or with opinion-building capacity. The public, which considers, reads, and joins events, is considered a subject in itself that acts, and not necessarily in pre-defined ways. That is why the public had to be defined and fought on a battlefield, the public sphere, while asking them to leave all their weapons at home in private people's respective areas of living.

\section{The Fostering Care of the Government: The River Thames Police}

At the turn of the century, in 1800, Patrick Colquhoun published his report on the River Thames Police, a force funded privately by traders in the London docks. Shortly after its publication, Colquhoun was assigned as one of the first publicly funded police commissioners, and his River Police became the first police force under the command of a centralized state authority in London's history. ${ }^{38}$ Contrary to widely accepted accounts of the history of police that give all the credit to Colquhoun for establishing the modern police, ${ }^{39} \mathrm{I}$ believe that it was a concerted effort of both earlier and contemporary

\footnotetext{
${ }^{38}$ Peter Linebaugh, The London Hanged, p. 433.

39 "In Justice and Police, a series of lectures published in 1885, F. W. Maitland wrote that "a full history of the new police would probably lay its first scene in Ireland, and begin with the Dublin
} 
intellectuals and political figures concerning police. ${ }^{40}$ Therefore, in my attempt to historicize the police, I infer Colquhoun's importance from his voluminous reports, namely his Treatise on the Police of the Metropolis Police (1795) and The Commerce and Police of the River Thames (1800), rather than from his supposed achievements with the River Thames Police and the Metropolitan Police. As well as being quite detailed reports that should be taken into account when discussing the police, they are made even more interesting by Colquhoun himself, as an intriguing figure standing at the centre of ruling class affairs: the intellectual atmosphere, traders and other merchants, daily encounters with labourers on the docks, and regular encounters with members of parliament. Colquhoun was a Scottish merchant who was well connected with the famous names of the time, with Edmund Burke, Edward Gibbon, and Adam Smith being his regular visitors. He collaborated closely with Jeremy Bentham on his police reform project. ${ }^{41} \mathrm{He}$ addressed his reports to the Public — a point I come back to later in this section. Yet, at the same time, he mirrored the panics, needs, discourses, and actual and possible actions of the ruling classes. His books provided enough data to reveal the "flattery and class hatred that together have exercised a powerful influence upon subsequent conceptions of law and order." 42

Police Act passed by the Irish Parliament in 1786." See Stanley Palmer, Police and Protest in England and Ireland 1780-1850, Cambridge University Press, 1988, p. xvi.

${ }^{40}$ Those different meanings attributed to Colquhoun's work throughout were well documented in David G. Barrie, "Patrick Colquhoun, the Scottish Enlightenment and Police Reform in Glasgow in the late Eighteenth Century," Crime, History and Societies 12:2, 2008, pp. 59-79.

${ }^{41}$ Linebaugh, The London Hanged, p. 427.

${ }^{42}$ Linebaugh, ibid., p. 428. 
The importance of Colquhoun's writing, then, does not lie in the fact that he was considered as the founder of the public police; rather it lies in the way in which he problematizes the issues that 'supposedly' enabled the establishment of a centralized body of public police. Exploring his way of problematization is also greatly informative about the way in which modern society was turned into the Public. I therefore aim here to investigate how he problematizes the situation of the labouring class, which he wishes to intervene on many different levels, as he explains in his remarks on the lottery:

the Revenue [that the present lottery system] produces might be preserved, with the incalculable advantage to the nation of preserving, at the same time, the morals of the people, and turning into a course of industry and usefulness the labour of many thousand individuals, who, instead of being, as at present, pests in Society, might be rendered useful members of the State. ${ }^{43}$

In other words, he attempts to turn a static version of a subject, namely 'Society,' into an approachable, addressable, responsible, and accountable subject, that is the public: "To whom [his writings] may concern". Among others, I identify five characteristics defining Colquhoun's problematization of the state of laboring people at the time, each addressing a field of inquiry that occupied the ruling classes: (1) modern scientific method, (2) political economy, (3) moral regulation, (4) building political order, and (5) spatial production.

First, in his preface to Treatise on the Police of the Metropolis, Colquhoun defines police "as a new science; the properties of which consist ... in those other functions which

${ }^{43}$ Colquhoun, Treatise on the Police of the Metropolis, p. 170. 
relate to internal regulations for the well ordering and comfort of civil society." 44 Relying on this need for internal regulations and complying with the so-called scientific obsession of the time, namely categorization and listing, Colquhoun's report was organized by the "metonymic technique of the list" as Mariana Valverde observes, ${ }^{45}$ or his attitude towards enumerating the wealth and crime was "Newtonian," as Linebaugh puts it. ${ }^{46}$ Referring to police as a science whose function is to regulate civil society, Colquhoun connects the eighteenth-century police ideal to the nineteenth-century police force. However, this does not mean that he and his contemporaries successfully classified the population as they had expected through their 'expert' knowledges. Their 'official will,' if we use the analogy Valverde applies to the law for the police, ${ }^{47}$ as reflected in their writings on police, do not necessarily reflect the 'Truth' about their times. Nevertheless, this does not mean that they did not influence the general discourse, or rather exert power effects on the order of the things. In time, these power effects made it look possible to classify and measure the people and their wills on political matters while these measurements also shaped the spine of the police force. Colquhoun sought to achieve the same by measuring the working class, “whose lodging-houses, street-sellers, horse-dealers, pawnbrokers, stablekeepers, second-

\footnotetext{
${ }^{44}$ Colquhoun, ibid.

${ }^{45}$ Mariana Valverde, Law's Dream of a Common Knowledge, Princeton and Oxford: Princeton University Press, 2003, p. 160.

${ }^{46}$ Linebaugh, The London Hanged, p. 427.

${ }^{47}$ Mariana Valverde, Law's Dream of a Common Knowledge, 2003.
} 
hand sellers, hawkers, pedlars, public houses, and old-iron shops he wished to count, register, and license. ${ }^{\prime 48}$

Second, Colquhoun's writing plays an important role in sketching and strategizing for the class war. Although it sounds like an overstatement, Linebaugh argues that "[i]f a single individual could be said to have been the planner and theorist of class struggle in the metropolis it would be he." 49 What Colquhoun's River Police did was, for example, to criminalize the customary takings of dock workers as a form of primitive accumulation, taking what was customarily in the control and possession of people. ${ }^{50}$ Colquhoun addressed the ruling classes' two main problems of the time, as identified by Corrigan and Sayer: "to legitimate the rights of property ... and to police the laboring poor into the habituation of their stations. ${ }^{" 51}$ His River Police not only patrolled the docks; they also had direct responsibility for paying wages, determining who would receive these wages, and how much, setting piece-rates, managing accounting, and taking full responsibility for the exploitation of labour. ${ }^{52}$ In other words, they legitimatized the rights to property and wagelabour. On the other hand, their interventions forced the labouring poor into the habituation of their stations not by violence but by cutting the chain of beneficiaries from the workers' customary takings. For customary remuneration required a community-wide network, including "marine-store-dealers, grocers, inn- and alehouse-keepers, landlords and brothel-

\footnotetext{
${ }^{48}$ Linebaugh, The London Hanged, p. 427.

${ }^{49}$ Linebaugh, The London Hanged, pp. 426-427.

${ }^{50}$ Linebaugh, ibid., p. 434.

${ }^{51}$ Corrigan and Sayer, The Great Arch, p. 96.

${ }^{52}$ Linebaugh, The London Hanged, pp. 433-434.
} 
owners with whom the river workers might barter or exchange their takings." 53 The communities around the docks providing food, drink, lodging, love, and care were essential for the urban economy of the poor. ${ }^{54}$ Colquhoun's police effectively intervened in this chain of relations to the disadvantage of the proletariat. The political economy was supposed to compensate for their loss; that is, in Arendtian terms, the expansion of the household economy to the nation and vice versa. Both Bentham and Colquhoun wrote advice regarding the administration of the household economy of the poor based on the nation's (i.e. the bourgeoisie's) economic needs. Bentham wrote Errors of the Present Practice of Cooking (1796) about how English cookery required too much labour and too much flour, and advised spreading bread with treacle in order to save on butter and to disguise the taste and colour of adulterated flour. This and similar advice helped make sugar, the "favored child of capitalism," an important component of the working class $\operatorname{diet}^{55}$

Third, the moral regulation aspect of Colquhoun's problematization can be read through the words of his close friend Bentham, who in 1802 stated clearly that the "most neglected class must become the principle object of care. The less parents are able to discharge their duty, the more necessary it is for government to fulfill it." 56 Colquhoun's River Police also emerged as a response to this urge of the ruling classes not to prevent crime but to regulate the morals and manners of the labouring classes to suit the new mode

\footnotetext{
${ }^{53}$ Linebaugh, ibid., p. 434.

${ }^{54}$ Linebaugh, ibid., p. 434.

${ }^{55}$ Linebaugh, The London Hanged, p. 411.

${ }^{56}$ Quoted in Corrigan and Sayer, The Great Arch, p. 126.
} 
of production, wage labour, and the battlefield, defined under the name of the public. The labouring class had to learn how to be the public, how to be on the receiving end of all the so-called benefits that ruling classes had to offer. The new moral regulation as prescribed by Colquhoun and his acquaintances also had a secular characteristic as the religious values that accompanied moral values were always kept separate in Colquhoun's writings: “Those Laws," he contends, "are the best which are most calculated to promote Religion and Morality; the operation of which in every State, is to produce a conduct intentionally directed towards the Public Good." 57 That is, his reference to the public is not religious since secularized laws and regulations would guarantee the public good. When he wrote about the morals of the labouring class in A New and Appropriate System of Education for the Labouring People, for example, he addresses it to the public "to accomplish the great object of National Education for the Children of the Poor." Moral reformers actively intervened against the 'old' much-enjoyed popular culture of this new army of labor to fabricate a 'new' productive one. Colquhoun's proposed Police Gazette was a moralizing force in that, while detailing the crimes committed, listing stolen goods, and providing criminal statistics, it was also going to be used to "excite in the minds of the laboring people a strong sense of moral virtue, loyalty and love of their country." Short essays, articles, and selections from the more moral sections of statutes were to be printed to show the importance of industrious activity and good behavior..$^{58}$

\footnotetext{
${ }^{57}$ Colquhoun, The Police of the Metropolis, p. 37.

${ }^{58}$ Neocleous, "Social Police and the Mechanisms of Prevention: Patrick Colquhoun and the Condition of Poverty," British Journal of Criminology 40, 2000, p. 716.
} 
Fourth, we observe a will to order the political structure of modern society, which made oppression of all causes in the name of stability more important. As Palmer notes, the police in its early years were more concerned with suppressing working class demonstrations than fighting crime. ${ }^{59}$ Insofar as the role of the new police was to define crimes, we see that everything that conflicted with the desire to hierarchize, order and control was criminalized. An increasing desire to control proletarian nights, for example, resulted in rising 'crime' figures in the first half of the nineteenth century ${ }^{60}$ Storch mentions the "new laws and regulations of all types, schools and policemen, as well as bosses and labour markets, which could not help but remind people every day of their limits" ${ }^{\prime 1}$ as to what was now acceptable or not in the public sphere. Like other reformers of the time, Colquhoun problematizes these ills, and in turn uses illness as analogy metaphor to further justify his problematization. He sees the poor as an epidemic: for him, they are contaminants so he proposes a police to sanitize class relations. ${ }^{62}$ Such a sanitization would define part of modern politics to be conducted in the public sphere.

\footnotetext{
${ }^{59}$ Stanley Palmer, Police and Protest in England and Ireland 1780-1850, Cambridge University Press, 1988, p. 9.

${ }^{60}$ Clive Emsley, "Crime in Nineteenth Century Britain," History Today 38:4, 1988, p.40. "Following criticisms in the press that crime in London was increasing during the late 1870 s, the Metropolitan Police drew up a memorandum for the Home Office protesting that the statistics were seriously distorted by a change in the way that offences were classified." Clive Emsley, "Crime in Nineteenth Century Britain," History Today 38:4, 1988, p.40.

${ }^{61}$ Rober D. Storch, "Introduction: Persistence and Change in Nineteenth-Century Popular Culture" in Popular Culture and Custom in Nineteenth-Century England, Robert D. Storch (ed.), New York: Routledge, 1982, p. 13.

${ }^{62}$ Linebaugh, The London Hanged, p. 428.
} 
Fifth, spatial concern also supported Colquhoun's problematization. While the construction of the London docks was an important advancement to trade, it also meant reorganizing existing space and producing a new space in East London. Linebaugh comments how, from the perspective of the area's working-class neighborhoods,

[t]he underground and non-monetary community was physically destroyed to make way for the docks ... once East End people had lived by the water, after the construction of the docks the water lived upon them. Of more significance than the submergence of the riverside neighbourhoods, which, however gigantic as labour, remained geographically limited, was the criminalization of the dockers' customary takings. ${ }^{63}$

This was not the only issue however as the ruling class in cities was not anonymous either. They were not "physically inaccessible, or effectively insulated by a professional and preventive police force." 64 The propertied classes' fears of possible attacks by the poor is very well described by a Tory poet, Southey, in 1812: "At this time nothing but the Army preserves us from the most dreadful of all calamities, an insurrection of the poor against the rich, and how long the Army may be depended upon is a question which I scarcely dare

\footnotetext{
${ }^{63}$ Linebaugh, The London Hanged, p. 434.

${ }^{64}$ Allan Silver, "The Demand for Order in Civil Society: A review of Some Themes in the History of Urban Crime, Police and Riot" in The Police Six Sociological Essays, David Joseph Bordua (ed.), Wiley, 1967, pp. 17-18.
} 
ask myself." 65 Thus, Colquhoun's proposed plan to make working class neighbourhoods more orderly was a response to such anxieties.

I believe these five characteristics define Colquhoun's work quite well when it comes to the problematization of the class struggle of the time. Nevertheless, considering Colquhoun's works, one needs to comment also on his so-called 'preventive principle.' Although writers who constantly define Colquhoun as the inventor of preventive police have strong grounds as Colquhoun constantly talks about 'the prevention of crimes,' I argue that it is rather 'the creation of crimes' that he deals with. In doing so, he is less concerned with preventing than with the scientification of the investigation of society, the exploitation of labour and normalization of wage labour, renovation of morals, intervention in working class politics, and spatialization of social control. Because preventive police means deploying police for no apparent crime, for seemingly nothing, such a step needed to be justified on the basis of potential crime. In fact, the real crime was the bourgeoisie's own crime of class robbery, which to conduct they needed lookouts. The new economic mentality, namely the 'political economy' based on wage-labour, could not have been realized without police power-hierarchizing, ordering, watching, supervising, surveilling, and punishing when necessary. As Colquhoun himself testifies, it was not to prevent crime but to renovate morals based on the new exploitation model: "The system now suggested,

\footnotetext{
${ }^{65}$ Quoted in Elie Halevy, A History of the English People Vol. I, E. I. Watkin and D. A. Barker (trans.), London: E. Benn, 1949, p. 292.
} 
is calculated to prevent, if possible, the seeds of villainy from being sown: or, if sown, to check their growth in the bud, and never permit them to ripen at all." 66

Moreover, it could not have been intended as a preventive police system as the criminal codes of modern governments were, to a great extent, shaped long after police action first began in urban spaces. Dubber notes that, at the time criminal codes began to be shaped, the ruling authorities did not know how to categorize police offences: "Bavaria, which had produced what is generally considered to be the first 'modern' German criminal code in 1813, tried to collect its police offenses in a separate 'police criminal code." A few examples can be quoted from the 1822 draft of the police criminal code:

failing to sweep the sidewalk every Saturday; unauthorized placing of a flower pot; attaching a weather vane without a lightning rod; skating on thin ice; begging; untimely chimney sweeping; failing to supply one's dog with a city tag; keeping a pigsty that faces the street; establishing a chemical laboratory in one's kitchen; unauthorized river bathing; disposing waste onto the street; obstructing a narrow street with a cart; carrying a stick in a crowd; ringing church bells during a rainstorm; operating a coach at excessive speed; horseback riding by a child; interrupting another's concert through excessive noise; drinking alcohol in a bar after 11 P.M.; failing to have one's child inoculated by age three; failing to make a timely appearance at the water pump in case of fire; failing to keep one's fire bucket in proper repair; failing to heed a request to abstain from exciting animals; engaging

\footnotetext{
${ }^{66}$ Patrick Colquhoun, 1795, “A Treatise on the Police of Metropolis," p. 15.
} 
an act that may endanger a pregnant woman or her fetus; failing to assist runaway children until official action has been taken; disseminating principles, opinions, or dispositions dangerous to the state; disseminating principles, opinions, or dispositions that are directed against the foundations of morality and religion or otherwise tend to discredit morals or religion; publicly making statements gravely insulting the admiration of the Highest Being. ${ }^{67}$

In light of this early list of police offences, one can argue that the greatest success of the police project lies in the fact that the citizens never know what is or is not a criminal act. As Valverde demonstrates in her explorations of everyday law, the bulk of law in reality "is made up not of criminal prohibitions but of thousands of regulations that seek to micromanage the spaces in which we live," and that both our domestic space and public spaces are equally micromanaged. ${ }^{68}$

In conclusion, the main duties of the police at this time were regulating relations between workers and their employers, workers and their fellow workers, and workers and other commoners. By 1828, the different agencies of London policing included the following: (1) the watch and ward of the City of London; (2) the watch and ward of the City of Westminster; (3) the numerous parish constables and independent watches; (4) the Bow Street Office and patrol establishment, which included the foot patrol, dismounted patrol, horse patrol and the Bow Street Runners; (5) the seven police offices created in 1792, modeled on the Bow Street magistrates; and (6) the River Police. There was little or

\footnotetext{
${ }^{67}$ Quoted in Dubber, The Police Power, pp. 75-76.

${ }^{68}$ Mariana Valverde, The Force of Law, Toronto: Groundwood Books, 2010, p. 34.
} 
no communication or cooperation among these different groups so their activities often interfered with each other, causing conflict, jealousy, corruption, and inefficiency. The main objective of the 1839 Metropolitan Police Act and various other improvement acts were parts of this same project to regulate and organize more effectively the everyday life of society's lower orders. In doing so, they defined a proletarian public distinct from the public. To achieve these goals, they made every effort to control, and stop when possible, a wide range of actions in public, such as "the beating or shaking of carpets in thoroughfares and the burning and dressing of corks, hoops, casks, and tubs, to the flying of kites, the playing of games to the annoyance of inhabitants, and the blowing of horns and noisy instruments." 69

\section{Questioning the Revolutionary Potential of the Proletarian Publics}

Thompson argues that the period between 1790 and 1830 marks the formation of the English working class with its class consciousness based on class identity and class interests. $^{70}$ Two simultaneous developments led the way to this. Economically, the increasing rate of exploitation of labour caused harsher relations between employer and labourer. Politically, while labourers had increased potential for freedom, this created more political oppression because the labourer "felt his unfreedom more" and felt he needed to resist it. This resistance to both economic exploitation and political oppression was met by

\footnotetext{
69 Storch, "Introduction: Persistence and Change in Nineteenth-Century Popular Culture" in Popular Culture and Custom in Nineteenth-Century England, Robert D. Storch (ed.), New York: Routledge, 1982, p. 14.

${ }^{70}$ E.P. Thompson, The Making of the English Working Class, p. 212.
} 
a violent response from either the employer or state forces, and often both. ${ }^{71}$ This helped labourers become aware of their own position in the new bourgeois social order. However, it was the form of the response from the ruling classes that shaped the labourer's sphere and means of action.

By 1832, working-class institutions had emerged, such as trade unions, friendly societies, educational and religious movements, political organizations, and periodicals, along with working-class intellectual traditions and community patterns. ${ }^{72}$ This was also a time when the English working class became more orderly and disciplined, more reserved, less violent and less spontaneous. ${ }^{73}$ I relate these concurrent yet somehow contradictory processes of gaining class consciousness and becoming more docile to the emergence of the public in general and the proletarian public in particular. As mentioned earlier, if the public sphere is seen as the sphere of politics under the bourgeois social order then its revolutionary potential is in question. Beginning in the second quarter of the nineteenth century, the proletarian public sphere took on a more organized form that resembled the institutions of the bourgeois public. This was achieved not only through the efforts of the ruling classes and employers but also, and even more so, by the proletariat themselves in building their own institutions of political impact in emulation of the bourgeoisie.

Although gaining class consciousness was important for the workers, implementing that consciousness in their own class ways was not always possible given the often pre-

\footnotetext{
${ }^{71}$ Thompson, The Making of the English Working Class, p. 217-218.

72 Thompson, ibid., p. 213.

73 Thompson, ibid., p. 451.
} 
figurative top-down structuration of the Kampfplatz through discursive and non-discursive power relations. This was reflected in the ways in which the proletariat shaped their own sphere of action. Their direct action in protests were transformed; their class solidarity was institutionalized like that of the bourgeoisie; they found their own intellectuals and developed their own radical press. While exploring each of these, I aim to demonstrate how events paved the way for the English working class to become distanced from their revolutionary potential and believe "that their problems could be solved by the political organization of the country," namely by signing and presenting a Charter to the parliament by the mid-century. ${ }^{74}$

By 1850 , the direct action of the proletariat in protests had been transformed significantly. In the eighteenth century, while the crowd might not have had class consciousness, it was not 'blind' either; the people often had clear objectives, knew what to demand, and how to negotiate this with the authorities. ${ }^{75}$ Thompson describes three characteristics of popular action in the eighteenth century: (1) an anonymous tradition of acts of darkness out of a fear of instant retaliation by the ruling power; (2) a counter-theatre of threat and sedition, of crowd symbolism in countering the rulers' studied theatrical style, including burning effigies, hanging boats from gallows, the illumination of windows, untiling houses; (3) a capacity for swift direct action that must be immediately successful or not at all. ${ }^{76}$ However, these characteristics had largely disappeared by the mid-nineteenth

\footnotetext{
${ }^{74}$ Dorothy Thompson, The Chartists: Popular Politics in the Industrial Revolution, London: Pantheon Books, 1984, p. 1.

${ }^{75}$ E.P. Thompson, "The Patricians and the Plebs," p. 71.

${ }^{76}$ Thompson, “The Patricians and the Plebs,” pp. 66-69.
} 
century as the ruling classes tried to make popular political action non-anonymous, benign, and predictable through various tactics and strategies defined under police power. Consequently, the working class no longer acted as agitators of the proletarian publics but as free and private members of the bourgeois public. As George Rudé explains, the oldstyle riot, "characterized by the widespread pulling-down of houses," disappeared, especially after the deflation of Chartism, and "public protest became less frequent and more muted."77 In this sense, the working class "made itself as much as it was made."78 Therefore, while agreeing with Thompson that "the working-class community of the early nineteenth century was the product, neither of paternalism nor of Methodism, but in a high degree of conscious working-class endeavor," ${ }^{\prime 79}$ one should be aware of the kind of publics that mediated such 'consciousness' of the working-class people.

This consciousness was built on what we can call working-class ethics in the first half of the nineteenth century. The knowledge of shared destiny among the working classes meant that in times of emergency, such as unemployment, strikes, sickness, or childbirth, neighbours helped each other. ${ }^{80}$ This collective self-consciousness in turn produced its corresponding values (e.g. class solidarity), institutions (e.g. Constitutional and Corresponding Societies), theory (e.g. disciplinary Sunday Schools where the poor learned

\footnotetext{
${ }^{77}$ George Rudé, "Protest and Punishment in Nineteenth-Century Britain," Albion: A Quarterly Journal Concerned with British Studies 5:1, 1973, pp. 1-23, p. 7 and p. 4.

${ }^{78}$ Thompson, The Making of the English Working Class, p. 213

79 Thompson, ibid., p. 457.

${ }^{80}$ Thompson, ibid., p. 463.
} 
to hold meetings instead of rioting), and newspapers (e.g. Penny Papers). ${ }^{81}$ The political radicalism of the nineteenth century drew on this collectivism. It is no secret that modern police power aimed to divide this collective consciousness to prevent its consolidation. To illustrate, as mentioned in the previous part, Colquhoun was deeply concerned about wellcoordinated plundering, and the main target of his River Thames Police was to break the chain of organized 'criminal activity' or the 'customary takings' of the workers. This concern alone shows that, while the ruling classes tried to keep the poor within demarcated borders of certain spatial governance as their habitation, they tried even harder to prevent their destiny becoming a shared one; if they were to share a destiny, it had to be the whole nation's destiny that they shared as the public. Accordingly, ideological apparatuses advised the poor that they were private individuals. Thus, it is safe to argue that the public is created by breaking up solidarity and collectivity (because the public comprises individuals not collectivities), and that the public sphere is mediated by the police rather than communicative action or deliberation. By the end of the nineteenth century, we can say that the formation of the bourgeois public sphere had been accomplished-while of course accepting that it is in a constant process of re-formation. The Constitutional Year Book for 1887 itemizes a "selected list" of eighty-five organizations that have the goals of "the promotion of particular objects in relation to public policy, the enforcement or alteration of certain laws, or the advancement of various political, religious or educational views." $\$ 2$ These organizations advocated a wide range of reforms to micro-manage the

\footnotetext{
${ }^{81}$ Thompson, The Making of the English Working Class, p. 464.

${ }^{82}$ Quoted in Howard LeRoy Malchow, "Victorian Pressure Groups: Directions for Research," Albion: A Quarterly Journal Concerned with British Studies 5:2, 1973, pp. 107-115, p. 113.
} 
public life of all, from marriage law to public parks.

Starting in the late 1790s, working-class people, in massive numbers, participated in educational movements, organized libraries and discussion groups, and established friendly societies to insure themselves against sickness, unemployment, or funeral expenses. ${ }^{83}$ All these efforts served their need to act effectively in the public sphere. The discipline implemented in these groups illustrates the bourgeois-like characteristics of these societies. Decency and regularity were their watchwords; their meticulous attention to procedure and institutional etiquette as well as rules such as sitting in a certain order or keeping the door locked at all times made them also disciplinary societies ${ }^{84}$ They also issued fines and penalties, such as for "reflecting upon" another member in receipt of sick money, being drunk on the Sabbath, striking another, "calling one another bye-names," entering the clubroom "in liquor", taking God's name in vain, failing to attend the funerals of brothers or their wives, failing to attend meetings, refusing to take turn in the officers rota, failing to keep silent when ordered, speaking at the same time, betting in the club, or disclosing secrets. ${ }^{85}$ On the other hand, these societies, whether more genteel or illmannered, actively regulated by the ruling class. According to Gosden, the regulation of friendly societies is important because the "[1]egislation and administrative machinery

\footnotetext{
${ }^{83}$ Rob Breton, "Genre in the Chartist Periodical" in Aruna Krishnamurthy (ed.), The WorkingClass Intellectual in Eighteenth- and Nineteenth-Century Britain, London: Ashgate, 2009, p. 113. And, Thompson, The Making of the English Working Class, p. 458.

${ }^{84}$ Thompson, The Making of the English Working Class, p. 457.

85 Thompson, ibid., p. 458.
} 
originally devised to deal with friendly societies, came to be extended to cover trade unions, co-operatives, building societies, loan societies and local savings banks." ${ }^{\prime 86}$

Despite all their disciplinary and preventive measures, the working class societies were unable to keep spies out. W.H. Reid, a spy for the Pitt government, published The Rise and Dissolution of the Infidel Societies in the Metropolis in 1800. In these societies, the working classes were creating their own intellectuals, which in itself increased ruling class anxiety. Reid identified three different groups influenced by the French Revolution: (1) "infidels, or political freethinkers, dedicated to moral and intellectual subversion," led mainly by William Godwin and his friends; (2) "an 'auxiliary' force of lower-class religious enthusiasts with a passion to overthrow the established order," referring mainly to the leadership of Thomas Spence; and (3) "the mainly artisan proponents of French Jacobin-republicanism," referring to John Thelwall. ${ }^{87}$ Among these working-class intellectuals, Thelwall stands out as one of the leaders of the London Corresponding Society (LCS). The LCS was founded in 1792 and remained active and very successful, with around 3,000 members, until outlawed by parliament in 1799. Its leaders were put on trial for high treason but acquitted. Its objective was to "set up a working-class corresponding society in the image of the Society for Constitutional Information (SCI) and

\footnotetext{
${ }^{86}$ P.H.J.H. Gosden, The Friendly Societies in England, 1815-1875, Manchester: The University Press, 1961, p. 8.

${ }^{87}$ Quoted in Aruna Krishnamurthy, "Coffeehouse vs. Alehouse: Notes on the Making of the Eighteenth-Century Working-Class Intellectual" in Aruna Krishnamurthy (ed.), The WorkingClass Intellectual in Eighteenth- and Nineteenth-Century Britain, London: Ashgate, 2009.
} 
other more gentlemanly organizations." 88 In his remarks on the founding of the LCS, Thomas Hardy explains that initially "a great deal of conversation was about giving a name to the society, whether the patriotic club - The reformation society - constitutional society." 89

The radical press in early nineteenth-century London can also be seen as mediating between political aims of the proletariat and current political crises. ${ }^{90}$ With the Stamp Tax of 1815 , any periodical containing 'news' of any kind was subject to a four-penny stamp duty. The aim was to prevent the production of low-priced political newspapers accessible to the working classes. Although the stamp duty was reduced to one penny in 1836 , in those twenty years, it only radicalized the press further ${ }^{91}$ while on the other hand involving the police more into the business of working-class publishing. It is thus a valuable example of how the act of 'making public' or the attempt to 'make the public' cannot exist without policing. These attempts to police the working-class press in the context of the stamp duty also enabled completely new genres to emerge that represented working class interests: "the radical presses that wanted to avoid the stamp but did not want to produce illegal material had to bury news items in other discourses."92 For example, William Cobbett's

\footnotetext{
${ }^{88}$ Krishnamurthy, "Coffeehouse vs. Alehouse: Notes on the Making of the Eighteenth-Century Working-Class Intellectual,” p. 96.

${ }^{89}$ Thomas Hardy, “Thomas Hardy's Account of the Origin of the London Corresponding Society, 1799" in Mary Thale (ed.), Selections from the Papers of the London Corresponding Society, 17921799, Cambridge: Cambridge University Press, 1983, p. 8.

${ }^{90}$ Rob Breton, "Violence and the Radical Imagination", Victorian Periodicals Review, 4:1, Spring 2011, p. 25.

${ }^{91}$ Louis James, Fiction for the Working Man, 1830-1850, London: Oxford University Press, 1963, p. 13.

${ }^{92}$ Breton, "Genre in the Chartist Periodical," p. 114.
} 
Political Register, published between 1802 and 1835, did not report on events, but instead commented on news, editorials, opinion pieces, and rants in order to convey the news without having to pay the duty. Cleave's Police Gazette, published between 1834 and 1836, on the other hand, conveyed news by mixing political news with 'non-political' news expressed in a style not commonly associated with reporting. In this way, it was "able to appeal to a readership that was already accustomed to crossing between genres." 93 According to Edward Jacobs, "the layout of Cleave's incited its audience to read politics into all items, however putatively non-political," which in turn both expanded the understanding of the reach of politics in people's everyday lives and made 'creative political interpretation' a form of political action. ${ }^{94}$

There was also a demand for "serious reading material among the workers." 95 Between 1830 and 1836, many newspapers and broadsheets were sold extensively despite the law, such as Working Man's Friend, Black Dwarf, Slap at the Church and Poor Man's Guardian. Over 700 people were imprisoned for selling these unstamped papers. The Guardian sold 12,000 to 15,000 copies weekly and the broadsheet Cleave's Weekly Police Gazette 20,000 to 40,000 copies, while The Times sold 10,000 copies daily. Although “very few of the working people can read well enough to read a newspaper; ... papers are taken (and read aloud) at the blacksmith's, the barber's and several public houses." 96 This fact

\footnotetext{
${ }^{93}$ Breton, "Genre in the Chartist Periodical," p. 114.

${ }^{94}$ Edward Jacobs, "The Politicization of Everyday Life in Cleave's Weekly Police Gazette (183436)," Victorian Periodical Review 41:3, 2008, p. 225.

${ }^{5}$ Ulrich Schwab, The Poetry of the Chartist Movement: A Literary and Historical Study, Dordrecht: Kluwer Academic Publishers, 1987, p. 27.

96 Thompson, The Making of the English Working Class, p. 447.
} 
increased the value of such gathering spaces for working people, who transformed the solitary action of reading in bourgeois culture into a collective action. In this sense, the radical press also contributed to the difference between the bourgeois and proletarian publics while also increasing the significance of the unstamped press as it had to embrace "popular, often sensational forms of reading pleasure which enhanced rather than diminished its radical appeal." 97

The Poor Man's Guardian (PMG) was the most famous of the unstamped papers. It was published between 1831 and 1835 by Henry Hetherington, who later played an important role in forming the London Working Men's Association in 1836 and in creating the Charter. The paper advocated a free press and universal suffrage, and supported other causes of working people while criticizing the Reform Bill, property relations, and the taxation system. The motto of the paper was 'knowledge is power.' Every copy of the $P M G$ was scrutinized and passages that might be criminal were underlined in red ink by the police and informers. ${ }^{98}$ The controlled language of $P M G$ essays, with a focus on property and systemic injustice, ran nearly opposite to the immediacy of journalism and the fight against real people. ${ }^{99}$ Rob Breton argues that there were so many other discourses at play that it is difficult to imagine "the autonomy of the political" in the $P M G$, in such immediate events as arrests, treatment of prisoners, or personal experience. He argues that "[t]he

\footnotetext{
${ }^{97}$ Ian Haywood, The Revolution in Popular Literature: Print, Politics and the People, 1790-1860, Cambridge: Cambridge University Press, 1984, p. 52.

${ }^{98}$ Patricia Hollis, The Pauper Press: A Study in Working-Class Radicalism in 1830s. London: Oxford University Press, 1970, p. 34.

${ }^{99}$ Breton, "Violence and the Radical Imagination," p. 16.
} 
language of the $P M G$ results from the interaction between immediate, emotionally-driven contexts of class solidarity and wider ones." ${ }^{100}$ The language of the paper, then, reflected an interplay between the older style of analysis and the search for a new one: references to taxation and corruption on the one hand, and the discourse on property and power, the oppression of capital and the exploitation of labour on the other. ${ }^{101}$

The rising literacy rates among workers and the serious didactic tone of these political magazines did not, however, mean that the proletariat were ready to leave their languages of street literature. This is demonstrated, according to Breton, by the success of a wide range of periodicals produced for working people in the early 1800 s that published "moralistic and emotionally charged ballads, fables, and tales; literary criticism and appreciation; gruesome crime reporting; didactic proverbs; satires and comedic dialogues; various forms of poverty; and class-oriented, political tirades and analyses." ${ }^{102}$ Cleave's was different from $P M G$ in its 'entertainment' value, which historians often see as explaining why it outsold $P M G \cdot{ }^{103}$ Although $P M G$ ceased publication in 1835 , the energy drawn from the paper had been channelled into the London Working Men's Association, established in 1836 primarily for skilled workers, which promoted Owenite socialism and the movement for general education. This association is accepted as one of the first foundations of Chartist movement, which transformed the cultural changes triggered by

\footnotetext{
${ }^{100}$ Breton, ibid., p. 38.

${ }^{101}$ Patricia Hollis, The Pauper Press, p.218.

102 Breton, "Genre in the Chartist Periodical," p. 113-114.

${ }^{103}$ Edward Jacobs, “The Politicization of Everyday Life in Cleave's Weekly Police Gazette (183436)," Victorian Periodical Review 41:3, 2008, pp. 225-247.
} 
the radical penny press into the form of organized labour. As Thompson shows,

[c]ultural hegemony may define the limits of what is possible, and inhibit the growth of alternative horizons and expectations, there is nothing determined or automatic about this process ... such hegemony, even when imposed successfully, does not impose an all-embracing view of life; rather, it imposes blinkers, which inhibit vision in certain directions while leaving it clear in others. It can co-exist with a very vigorous self-activating culture of the people, derived from their own experience and resources. ${ }^{104}$

I believe the value of all the radical press and working class friendly societies lies in their contribution to the counter-cultural hegemony insofar as they draw on their own workingclass experiences and resources. Thus, Cleave's was an attempt to create a form and content based on the proletarian experience, leading to a new genre in dialectical relation to the widely-accepted bourgeois press and its way of making news. When this effort to create a sphere for the proletarian experience was disrupted by the working-class themselves, and when they began to express themselves in the bourgeoisie's language and accept the bourgeois way of making news and politics, one can no longer talk about the peculiar proletarian public sphere. If we follow Marx's definition of the proletariat then its universal experience of suffering cannot be reduced to certain rights claims in the public sphere. That is, the proletariat as a sphere have to emancipate themselves from the other spheres comprising a society.

\footnotetext{
104 Thompson, “The Patricians and the Plebs," p. 87.
} 
In The Critique of Hegel's Philosophy of Right, Marx defines the proletariat in relation to civil society:

a class of civil society which is not a class of civil society, an estate which is the dissolution of all estates, a sphere which has a universal character by its universal suffering and claims no particular right because no particular wrong, but wrong generally, is perpetuated against it. ${ }^{105}$

For Marx the proletariat is a sphere,

which cannot emancipate itself without emancipating itself from all other spheres of society and thereby emancipating all other spheres of society, which, in a word, is the complete loss of man and hence can win itself only through the complete rewinning of man. This dissolution of society as a particular estate is the proletariat. ${ }^{106}$

As indicated earlier, according to Negt and Kluge, the empirical working-class public sphere appears in two forms: as an encampment and as a version of the bourgeois public sphere. When the proletariat are organized as a camp, in the case of workers' societies, they reduce the chances of forming a proletarian public sphere that presumably encompasses the entire society; instead, they increase their own policing, as the example workers' friendly societies demonstrates. Since the proletarian context of life cannot evolve into

\footnotetext{
${ }^{105}$ Marx, "Introduction," A Contribution to The Critique of Hegel's Philosophy of Right, [1844] (emphases are original).

${ }^{106}$ Marx, "Introduction," A Contribution to The Critique of Hegel's Philosophy of Right, [1844] (emphases are original).
} 
such a broad public sphere, this camp, even though its intention is to free itself from the bourgeois context, will inescapably re-produce the mechanisms of the bourgeois public sphere in the sense of creating its own procedures. It will maintain itself through practices of exclusion, pseudo-publicity, and the dictatorship of procedural rules. It is therefore important to understand that the proletarian public sphere should emerge, not as a result of an attempt to make the public sphere more democratic and inclusive, but by breaking down completely the very building blocks of the existing public sphere.

\section{Conclusion}

In this chapter, I have tried to show the importance of the concept of the proletarian public sphere for understanding the relation between the emergence of proletarian class consciousness and the emergence of the modern police force in London, England in the late eighteenth and early nineteenth century. I have tried to demonstrate that the public sphere is made possible through the implementation of police power, particularly in the case of the proletarian public sphere. The anxiety of the ruling classes during the late eighteenth and early nineteenth century defined the proletarian publics from above while later attempting to destroy the same publics from below through police power. The ruling classes defined in detail what would be tolerated in public by developing and implementing a "base-line public order," in Storch's words, ${ }^{107}$ through police offences regulating, among other things, newspapers, moral tracts, foot patrols, and licensing. Over the long term, such

107 Storch, "Introduction: Persistence and Change in Nineteenth-Century Popular Culture" in Popular Culture and Custom in Nineteenth-Century England, Robert D. Storch (ed.), New York: Routledge, 1982, p. 13. 
activities became more closely supervised and regulated by the state and non-state authorities acting in coordination.

In a sense, this period represents an attempt to create the public out of communities of kinship, neighbourhoods, and so on. Following Thompson, this chapter can be concluded by drawing on the perspective that class is a social and cultural formation that "cannot be defined abstractly, or in isolation, but only in terms of relationship with other classes; and, ultimately, the definition can only be made in the medium of time - that is, action and reaction, change and conflict." ${ }^{108}$ I have tried to demonstrate in this chapter how the proletarian publics as social and cultural formations were constantly formed, deformed, and re-formed in relation to the bourgeois public sphere, often by criminalizing the act of making public in order to achieve the aim of making the public. I make a similar link between the proletarian and market publics in the next chapter.

\footnotetext{
${ }^{108}$ E. P. Thompson, “The Peculiarities of the English,” The Socialist Register 2, 1965, pp. 311-362, p. 357 (emphasis is original).
} 


\section{CHAPTER SIX}

\section{MARKET-PUBLICS:}

\section{THE PUBLIC SIGNIFICANCE OF THE PRIVATE SPHERES}

... the visible power of the market materialized as its 'private' buildings, urban mansions, department stores, company headquarters, chambers of commerce, and the equivalent moral powers standing out grimly in those 'objects of terror,' the union workhouses after 1834, through the central police stations from the later 1830s and especially 1850s, on to the schools after $1870 \ldots$

Corrigan and Sayer, The Great Arch, 1985

In this chapter, I aim to reveal the role of commodities or, better, reification in the deformation of the proletarian publics through joint action by market and police. To do so, I challenge both mainstream theories of the public sphere and theories that are critical of the public sphere, and instead theorize the market, a space deemed private, as a public sphere. In the introduction, I described the commodity-like character of the public sphere in detail. Here, I draw on lived examples to illustrate that the commodity character of the public sphere is far from metaphorical when it comes to market-publics. I also provide further examples of the proletarian public spheres to demonstrate the joint action of marketpublics and the police in shaping and controlling proletarian activities in both working and non-working space and time.

Accordingly, in the first part, I discuss the public relevance of the market sphere to theorize the concept of the market-public. I then consider the emergence of department 
stores as early shopping centers in the second half of the nineteenth century to understand their implications for the exploitation of labour power and use of police power through their newly-invented disciplinary technologies. I also argue that it is again thanks to the police power that department stores as market-publics became possible in the history of capitalism. In the third part, I look at examples of the commercialization of both public and private spheres, in particular those once commonly enjoyed spaces and activities of working-class recreation, and the ways in which the new police force functioned in commercialization and maintaining the new commercial order.

\section{Market-Police Joint Action in Proletarian Spaces}

The historical significance of the transition from the eighteenth to the nineteenth century for modern public life is often demonstrated by reference to the rise of consumerbased market values. As mentioned earlier, Arendt sees this as the rise of the social ${ }^{1}$ while Habermas conceptualizes it as the colonization of the lifeworld. ${ }^{2}$ The categorization of the market sphere as distinct from the public sphere, as its exact opposite, or as its enemy, relies on the assumption that the market belongs to the private sphere, irrelevant for the public and hence for political action. Unlike Arendt and Habermas, Richard Sennett includes mundane life practices in his sociological definition of the public and does not see the public sphere as a mere political mechanism in the service of the bourgeoisie. Sennett acknowledges that public life did not emerge in the eighteenth century; rather, he argues,

\footnotetext{
${ }^{1}$ Hannah Arendt, The Human Condition, [1958]1998, p. 28.

2 Jürgen Habermas, "Modernity versus Postmodernity" in New German Critique, No. 22, Winter, 1981, pp. 3-14.
} 
a modern version of public life took form in that period. Similarly to Habermas, Sennett pays too much attention to eighteenth-century public life; so much so that he even argues that if the nineteenth century populace did not avoid the permanent cataclysm of nineteenth-century city life and continued to overcrowd the city centers despite its instability, it was because of this culture of the public realm that had been created in the eighteenth century. ${ }^{3}$ He explores eighteenth-century public life with reference to one of the oldest Western ideas of human society: the theatrum mundi-seeing society as a theatre stage. Sennett argues that this ideal finds its meaning in eighteenth-century public life, and quotes from Henry Fielding, who remarked in 1749 that "the world as a theatre [was] no longer only a metaphor." 4 Public life in this century was formed through a bridge between the theatre stage and the street. Role-playing individuals in the public sphere imagined each other as the audience; stage and street intermingled regarding costumes and people's street clothing, their manners and attitudes. This bridge, according to Sennett, gave people the means to socialize on impersonal grounds: action at a distance from the self-regulatory mechanism that bridged diversity among strangers on the street. ${ }^{5}$ The institution for this new understanding of the public became publicly accessible spaces, such as public parks, designed to make walking and carriage rides easy. Taking walks in the park became a means of maintaining social relations between classes through spontaneous encounters.

\footnotetext{
${ }^{3}$ Sennett, The Fall of Public Man, 1992, p. 140.

${ }^{4}$ Quoted in Sennett, ibid., p. 64.

${ }^{5}$ Sennett, ibid., p. 64.
} 
In parallel to Arendt and Habermas, Sennett argues that "the bourgeoisie deformed, to the point where nothing remained, the modes developed in the eighteenth century of conducting meaningful life." ${ }^{\prime 6}$ Nevertheless, he acknowledges the emerging public form specific to the nineteenth century—and to the centuries that followed: "the public realm as an active interchange gave way in people's lives to an experience of publicness more intense and less sociable." ${ }^{, 7}$ What is it that made nineteenth-century public less political for Arendt and Habermas, and less social for Sennett? To what extent was society as a whole acting politically consciously or socially intentionally before the nineteenth century? Which segments of the population became less sociable and less political? These are questions left unanswered by both Arendt and Habermas, and to a certain extent by Sennett.

Both Arendt and Habermas refer to the deformative aspects of industrialization and organized capitalism in making their arguments, but without providing concrete examples. Instead, their arguments are based more on the 'rise of the social' and the 'colonization' of the public by the market. Similarly, Sennett emphasizes impersonal relations among individuals in eighteenth-century public life, seeing this impersonality as an important component of developing a public culture. For Sennett, the economic facts of the nineteenth century allowed personality to have priority in the relations people developed 'out in the public.' Sennett's emphasis on impersonality in the eighteenth century and the transition from this impersonality to the rise of personality in the nineteenth century can be related to the question of anonymity. Being anonymous in public is one way to define freedom in the

\footnotetext{
${ }^{6}$ Sennett, ibid., p. 141.

${ }^{7}$ Sennett, ibid., p. 141.
} 
public. With the emergence of police science in the eighteenth century and the modern police force in the nineteenth century, we observe a breach of this anonymity in the public. As demonstrated in the previous chapter, the new governmental technology, aside from its aims of calculability and predictability, aimed to make people identifiable, thereby ending their anonymity.

According to Sennett, nineteenth-century industrial capitalism had a double relationship to public life that showed itself first in the pressures of privatization and second in the "mystification of material life" in public caused by mass production and distribution. ${ }^{8}$ By privatization, Sennett refers to the change in bourgeoisie's public visibility. He highlights how the bourgeois family was used as a standard of good morals while at the same time becoming a refuge from the terrors of public life. ${ }^{9}$ I extend his argument to include the proletariat in this change, with a slight shift of focus towards the interventions of police power in the life context of the proletariat. By mystification, he emphasizes mass production and commodity distribution, which he believes transformed material social relations in public into relations between commodities; in a sense, although he never openly names it, reification.

As I interpret them, Negt and Kluge define the "new industrialized public spheres of production" as referring to the public-making potential of the mass media and advertising sector, particularly in the twentieth century. In this, they build on the argument that the industrialized public spheres of production only became relevant for the public and

\footnotetext{
${ }^{8}$ Sennett, ibid., p. 19.

${ }^{9}$ Sennett, ibid., p. 20.
} 
thus for political action in the twentieth century with the emergence of the advertising sector, widely referred to as "public relations." However, Negt and Kluge ignore that the market sphere and its governance have always been relevant to public concerns and thus political actions, and used accordingly for many years by the ruling classes. As Corrigan and Sayer define the market "is a regulated social relation policed by force and moralized by a 'willing' discipline." 10

Throughout the sixteenth and into the seventeenth century, the market place was seen as "the forum for discipline" and "the theatre of punishment of delinquents." 11 Public penance meant the ritual humiliation and expiation of the condemned in public space, with the most appropriate space being the market place. Its use was not done without consent; instead, just like any other public space, and perhaps in a more complicated way than others, it was "negotiated, informed by the micro-politics of place and confessional category" 12 with the everyday users (consumers), beneficiaries (sellers), and legislative authorities (watchmen). From another angle, E. P. Thompson points out the significance of the already established consumer culture in the eighteenth century by showing that "a consumer-consciousness preceded other forms of political or industrial antagonism. Not wages, but the cost of bread, was the most sensitive indicator of popular discontent ... Any sharp rise in prices precipitated riot." 13 Thus, nineteenth- and twentieth-century consumer

\footnotetext{
${ }^{10}$ Corrigan and Sayer, The Great Arch, p. 106.

${ }^{11}$ Dave Postles, “The Market Place as Space in Early Modern England," Social History 29:1, 2004, pp. 41-58, p. 58.

12 Postles, ibid., p. 58.

${ }^{13}$ Thompson, The Making of the English Working Class, [1963]1991, p. 68.
} 
culture was not fabricated from scratch but built on a consumer consciousness that had existed since at least the sixteenth century.

In the late eighteenth and early nineteenth century, however, the main problem, I suggest, was not the rise of consumer culture but the rise of a particular form of consumer culture. And this was only one structural consequence of three other changes that occurred in this period in addition to the most obvious one - the industrial mass production of goods. First, as police power became the dominant mode of power, "the state and its agencies became not only more willing to legislate in such areas, but also proved willing to create and fund enforcement agencies" to intervene in the ways in which people consumed. ${ }^{14}$ This in turn transformed popular culture. Closer regulation, surveillance, and licensing moved various traditional cultural practices in specific directions "without the need to engage in ... overt repressive activities" while "forcing others ... into more clandestine and invisible channels, where they would inevitably lose contact with a portion of their former publics." 15 The implications of increasing control over consumption patterns were direct on the ways in which working classes acted in public. ${ }^{16}$ I call this the 'domestication of proletarian manners.' The main concern at this point was "how could the magistrates or the police by themselves change men's characters and produce greater orderliness, less

\footnotetext{
${ }^{14}$ Storch, "Introduction: Persistence and Change in Nineteenth-Century Popular Culture" in Popular Culture and Custom in Nineteenth-Century England, Robert D. Storch (ed.), New York: Routledge, 1982, pp. 15-16.

${ }^{15}$ Storch, ibid., pp. 15-16.

${ }^{16}$ Here, it should be noted that, as Hunt demonstrated, modern regulation of consumption clearly has its roots in the earlier tradition of sumptuary laws dating back to the Middle Ages, from 1050 onwards. Alan Hunt, Governance of the Consuming Passions: A History of Sumptuary Law, New York: St. Martin's Press, 1996.
} 
dangerous political ideas and social longings among those below?" 17 Capitalism's tendency to expand changed the market-publics in a way in which anything and everything could be commodified and included there. Both marketization (or privatization) and nationalization (or public-ization) of old spheres of recreation were conducted under increasing police control in parallel to primitive accumulation.

Second, industrialization of both production and distribution influenced the transformation of the market-publics. Industrialization in distribution revealed itself in the system of fixed price, among other effects. This turned the market into a place of verification, starting in the late eighteenth century. As Foucault claims, "the market becomes a site of truth" during this period. ${ }^{18}$ A new definitive, acceptable relationship between the cost of production and level of demand legitimized a particular price—called the 'natural price,' 'good price,' 'normal price,' or 'true price.' Therefore, Foucault argues, the market became a site of verification-falsification for governmental practice; it was no longer a site of distributive justice as in the Middle Ages. ${ }^{19}$ To elaborate, until the mideighteenth century, the market place was a place of negotiation and conflict-not only commercial negotiations but also social negotiations; so much so, they were places "representing civic honour." 20 Both ordinary people and the servants of 'gentlemen' shopped for everyday products in these places of bargaining. People performed while shopping through person-to-person relationships, with commodities being priced

\footnotetext{
${ }^{17}$ Storch, "Introduction: Persistence and Change in Nineteenth-Century Popular Culture," p. 4.

${ }^{18}$ Foucault, The Birth of Biopolitics, 2008, p. 31.

${ }^{19}$ Foucault, ibid., pp. 29-35.

${ }^{20}$ Postless, “The Market Place as Space,” pp. 41-58.
} 
according to people's income level and the stories they told. And it was, as in Arendt's idealized ancient Greek agora, "not a meeting place of citizens, but a market place where craftsmen could show and exchange their products." ${ }^{21}$ The characteristic of these market places was that "the display of goods for sale was accompanied by a display of their production" to the extent that Arendt calls it "conspicuous production," reformulating Veblen's conceptualization of "conspicuous consumption."22 In Marxian terms, both producer and consumer experienced less alienation in these spheres of interaction. Yet, drawing on Foucault, it can also be argued that, as the site of truth, the market-publics became the major contributor to the production of the truth regimes surrounding the discursive field of politics. As a structural consequence, we can then talk about the dominance of market values that necessarily benefit the share-holders in the marketpublics. This can also be expanded to consider production. Similarly, the determination of minimum wages based on the minimum necessary subsistence of workers is a claim to truth. This then leads to (de)criminalization and (im)moralization, along with coercion and consent as strategies to govern this new order of verification in the market.

Third, industrialization of production, distribution, and consumption simply meant that, starting in the second half of the nineteenth century, the everyday life elements of the working classes were increasingly taken as raw material and processed for the benefit of capital in the market-publics. The biggest implication of this was the transformation in the working classes' horizon of experience. That is, the market-publics' capacity to combine

\footnotetext{
${ }^{21}$ Arendt, The Human Condition, [1958]1998, p. 160.

${ }^{22}$ Arendt, ibid, p. 160.
} 
the everyday needs of the proletariat with the interests of capital to a certain extent redefined the interests of the proletariat. In this sense, the structure of market-publics embraced not only the interests of the bourgeoisie but also the re-defined interests of the proletariat, insofar as they were integrated with capital as its producers, distributers, and/or consumers.

Under capitalism, we cannot talk about a space emancipated from the market, involving all aspects of production, distribution, and consumption. And without capitalism's first condition of private property, we cannot talk about the public. It is therefore intrinsically contradictory (and dangerous) to reject the public relevance of the market sphere or market-publics. Instead of rejecting it or talking about its colonization of public life, one should, I believe, understand its significance in transforming the masses into the public. The market-public should be theorized to explain its collaboration with, use of, and contribution to police power to further expand its territory. Otherwise, it becomes difficult to understand how the way the public was constructed, or how politics in capitalist social orders functions as a market-public, is a by-product of the capitalist mode of production and its social order. As Storch argues, "[t]he reform of popular values and customs inevitably became intimately bound up with the nineteenth-century problems of public order and social and industrial discipline." ${ }^{23}$ Hence, nineteenth-century popular values and customs, which were the main target of modern police power, were not only a concern for the bourgeois public sphere but also, and increasingly so, a concern for the

\footnotetext{
${ }^{23}$ Storch, "Introduction: Persistence and Change in Nineteenth-Century Popular Culture," p. 3.
} 
market-public as it related to the consumption, production, and distribution patterns of the working classes.

I refer to these new spaces of the market involving the labour-market, the distribution of mass-produced goods, and newly commercialized spaces of socialization as market-public spheres. They are the spaces in which capitalism consolidated its culture in the new social order. Moreover, in parallel to Sennett's argument that the nineteenthcentury public sphere continued to exist because of the public culture developed in the eighteenth century, I argue that, since the nineteenth century, capitalist production and distribution has utilized the public culture developed in the eighteenth century. Without this public culture, capitalism would not have consolidated its cultural hegemony. Social relations took on a new shape through these market-public spheres where the relationship of the commodities in exchange replaced the relationship between people, as in Marx's definition of reification. In other words, I argue that, what André Gorz calls "economic reason," is fundamental to public action through these market-public spheres:

It was the art of calculation, as developed by science, applied to the definition of the rules of conduct. It raised the quest for efficiency to the level of an 'exact science' and thus cleared the factors of moral or aesthetic criteria from the field of decision-making. Thus rationalized, economic activity could henceforth organize human behaviour and relationships 'objectively,' leaving the subjectivity of 
decision-makers out of account and making it impossible to raise a moral challenge on them. It was no longer a question of good or evil but only of correct calculation. ${ }^{24}$

The success of the market-public spheres lies in their enormous rapidity in transforming life contexts. It does not take very long for people to adopt the required attitudes and manners in these planned spaces of socialization as they appeal to people's fantasy world and respond to their everyday problems. While the material needs of workers are being communicated in these spheres, a form of conduct is also being taught. The thing 'for sale' in the market-publics is a pre-defined life and learning context. Thus, when people enter these spheres, they are subjected to a particular kind of culturalisation and moralisation. The culture of this 'commodity-public' is heavily informed by the culture of capitalism, profit-making, competition, and ambition. The culture of capitalism also brings forth a certain understanding of history(lessness). People are left without a personal history narrative and surrounded by the particular non-contextual values presented in the marketpublics. By forcing people to accept and include these values in their lives result in "[ $[\mathrm{t}] \mathrm{he}$ capacity to let go of one's past, the confidence to accept fragmentation."25

In his influential article on publics and counterpublics, Michael Warner states that "[p]ublics have to be understood as mediated by cultural forms, even though some of those forms work by denying their own constitutive role as cultural forms." ${ }^{26}$ In the market-

\footnotetext{
${ }^{24}$ André Gorz, Critique of Economic Reason, Gillian Handyside and Chris Turner (trans.), London and New York: Verso, 1989, p. 122.

${ }^{25}$ Richard Sennett, The Corrosion of Character: The Personal Consequences of Work in the New Capitalism, New York: W. W. Norton \& Company, 1998, p. 63.

${ }^{26}$ Michael Warner, "Publics and Counterpublics," Public Culture 14(1): 49-90, 2002, p. 54.
} 
public spheres, however, as Hansen points out, the cultural forms of "art and literature" have occupied public discourse and constituted the centre of the public sphere in the name of the normative function of culture. ${ }^{27}$ The market-public spheres fabricate a culture through commodities in which certain moral and aesthetic values are congealed. In this way, the transforming elements and rebellious nature of culture is negated in the marketpublic spheres. The mass culture fabricated in these spheres of the market "corresponds to the behaviour of the prisoner who loves his cell because he has been left nothing else to love," as Adorno puts it. ${ }^{28}$ The (commercial) market sphere and its actors (commodities) constitute a public in which only mass behaviour is possible, not collective action. ${ }^{29}$

On the other hand, Lukács describes the world surrounded by commodities as a "second nature," he talks about the difficulties within this second nature of developing class-consciousness vis-à-vis reified social relations. ${ }^{30}$ In this sense, we are exposed to his pessimism regarding resistance. From a slightly different angle, Adorno argues that "the total effect of the culture industry is one of anti-enlightenment, in which ... enlightenment ... becomes mass deception and is turned into a means for fettering consciousness." ${ }^{31}$ In

\footnotetext{
${ }^{27}$ Hansen, "Introduction", 1993, p. xiii.

${ }^{28}$ Theodor W. Adorno, The Culture Industry, J. M. Bernstein (ed.), London and New York: Routledge, 2008, p. 40.

${ }^{29}$ For the difference between action and behaviour, I rely on the Arendtian definition of action and behaviour.

${ }^{30}$ George Lukacs, History and Class Consciousness: Studies in Marxist Dialectics, Rodney Livingstone (trans.), Massachusetts: The MIT Press Cambridge, 1971, p. 86. However, it seems to me that, according to Lukács, there is no way out from this second nature back to the first nature as long as we live in a capitalist society.
}

${ }^{31}$ Adorno, The Culture Industry, 2008, p. 106. 
other words, reason "turns against the true aims of Enlightenment: freedom and happiness." 32

So, the question emerges: if reality changes consciousness, as Marx points out; if workers are going to find their own ways in order to have immediate experiences turned into mediated ones; if this process of mediation can only be realized in an environment where workers can share and discuss their lived experiences; and if non-working times and places are surrounded by reified relations then where will the revolution be organized? Will it be organized in working times and places where workers find it irreversibly harder to smile on their own but obey the strict standards of manners of how and when to smile through advanced discipline and control mechanisms? In referring to the market, or second nature, as a public sphere, my aim is to reveal the possible revolutionary potentials of these specific fields of action vis-à-vis their role in preventing such actions.

\section{The Case of Department Stores}

Sennett sees the rise of the department stores as one of the clearest indicators of how eighteenth-century public life was transformed in the nineteenth century. He states that "the machine production of a variety of goods, sold for the first time in a massmerchandising setting, the department store, succeeded with the public not through appeals to utility or cheap price, but rather by capitalizing on this mystification." 33 I follow Sennett's example of the department stores with nuance to exemplify the operation of the

\footnotetext{
32 Jay Bernstein, "Introduction" in The Culture Industry, 2008, p. 5.

${ }^{33}$ Sennett, The Fall of Public Man, 1992, p. 20.
} 
market-publics. If we accept the assumption that "everyday consumption is a kind of production or creation, since it involves people imposing meanings on objects," 34 then this transition from bazaars to retail stores, to department stores and then to shopping malls has lots to tell about the social production of meaning in the nineteenth century because this new way of imposing meaning on objects brings forth a new form of conduct among people out in the public.

Walter Benjamin's attention to Paris arcades is significant to understand the public relevance of the market place. Most Paris arcades emerged after 1822, and were considered the forerunners of department stores. Benjamin observes that the "first condition for their emergence was the boom in the textile trade," ${ }^{35}$ with the sale of textiles and home furniture being easier in such shopping complexes. Benjamin quotes from an "Illustrated Paris Guide" of the time:

These arcades, a new contrivance of industrial luxury, are glass-covered, marbledfloored passages through entire blocks of houses, whose proprietors have joined forces in the venture. On both sides of these passages, which obtain their light from above, there are arrayed the most elegant shops, so that such an arcade is a city, indeed a world, in miniature. ${ }^{36}$

\footnotetext{
${ }^{34}$ Burke, Popular Culture in Early Modern Europe, p. 13. Here, Burke paraphrases Roger Chartier, who followed the suggestions of French social theorist Michel De Certeau. Chartier mainly argues against identifying popular culture by the distribution of some specific cultural objects, such as books, as he believes these objects are in practice used or appropriated by different social groups for different purposes.

${ }^{35}$ Walter Benjamin, "Paris —Capital of the Nineteenth Century," [1935], pp. 77-78.

${ }^{36}$ Quoted in Benjamin, ibid., p. 78.
} 
Like the arcades, the department store was a consequence of urbanization that benefitted from the urban-based economy of space. Vertical buildings compartmentalized goods between different floors and made each open floor a condensed area for shopping. The architecture also made it possible to better control the space, creating a 'secure' space for both shoppers and, more importantly, shop owners. The department store being a result of urbanization was also, as observed quite well in Benjamin's quotation above, designed as "a city, indeed a world, in miniature." ${ }^{37}$ Their claim to carry a world of goods within themselves drew in the hinterland of the city as well as other surrounding cities. In so doing, they represented time-space compression, to use David Harvey's well-known terminology. ${ }^{38}$ Or, to apply Wolfgang Schivelbusch's less well-known analogy of the speed of the railroad, it can be argued that "the alteration of spatial relationships by [the variety of compressed stocks in the department store] is not simply a process that diminishes space, but it is a dual one: it both diminishes and expands space." ${ }^{39}$ In this sense, the department stores have world-creating potential as well as the potential to produce "men of the world" (sic.) similarly to Arendt's definition of the public sphere. ${ }^{40}$ The difference is that the elements and places of the world in this case were represented not in ideas and speeches

\footnotetext{
${ }^{37}$ Benjamin, ibid, p. 78.

${ }^{38}$ David Harvey, The Condition of Postmodernity: An Enquiry into the Origins of Cultural Change, Cambridge and Oxford: Blackwell, 1990. Although Harvey uses the term to refer to postmodern times, it is a process that began long before. Indeed, Schivelbusch explains a similar situation with more nuance in his historical analysis of the nineteenth century. Schivelbusch, The Railway Journey: The Industrialization of Time and Space in the 19th Century, Berkeley and Los Angeles: University of California Press, [1977]1986.

${ }^{39}$ Schivelbusch, The Railway Journey, [1977]1986, p. 35.

${ }^{40}$ As indicated in the second chapter, Kant spoke of the public sphere as the 'world' and referred to the 'man of the world.' Following Kant, Arendt emphasizes the world-creating potential of the public sphere, too. See Arendt, The Human Condition, [1958]1998, p. 50 and 52.
} 
but in commodities, and that communicative action took place less between private persons than between commodities and persons.

When we think of modern institutions, we tend to leave out consumption-based examples. However, department stores, in this example, carry as many characteristics of modern public institution as prisons, schools, hospitals, and factories do. The ways in which department stores are organized are no different than the disciplinary mechanisms of the modern liberal governmentality of police power. They confine people, maintain a constant watch without being seen, and, most importantly of all, they do not imprison their inmates with iron bars or walls but with shiny commodities on conspicuous display. The department store is also an indicator of modernization as it represents a shift "in the character of social relationships, a shift in tone and sensibility that in cultural forms of representation. ${ }^{41}$ In that, as with other features of modernization, the department store identified itself as an extension of freedom for its customers. ${ }^{42}$ The customers free, not only to browse in the open plan of a large store, but also to choose in their own time from the variety of goods. However, as David Chaney argues, this freedom was alienating: it asked customers to choose their own 'distinct' life-styles among the mass produced 'standardized' goods. ${ }^{43}$ Thus, the experience of shopping at the department store was simultaneously totalizing and individualizing. At the same time, the department store also caused a shift in the social skills of customers. "Abstract contemplation of relative worth,"

\footnotetext{
${ }^{41}$ David Chaney, "The Department Store as a Cultural Form," Theory, Culture and Society 1:3, 1983, pp. 22-31, p. 26.

${ }^{42}$ Chaney, ibid., p. 22.

${ }^{43}$ Chaney, ibid., p. 23.
} 
in Chaney's words, replaced barter in the earlier form of the market place. ${ }^{44}$ Hrant Pasdermadjian celebrates this feature in his book on the economic 'success' of the department stores: "It gave the woman purchaser the opportunity to 'shop,' that is to say to go about through the various departments of a department store, or the corresponding departments of different department stores, comparing qualities, prices, styles and values to her heart's content." 45

However, aesthetic presentation of commodities preceded all other features. As W. Hamish Fraser puts it, in his attempt to show how civilizing this new form of distribution was, "[t]here was no pressure to purchase: or rather, the pressure to purchase was through the eye, not through the ear, seduced by the smooth words of the salesman." 46 Perhaps, for the first time, conspicuous consumption (of selected goods) was encouraged so openly for the 'non-leisure' classes, at the risk of decomposing Veblen's term. A culture of consuming for the sake of it slowly became the norm among the working classes as the new department stores that opened in the last quarter of the nineteenth century looked to these classes as their main customers. Free entry to the shop with no commitment to purchase also mediated this since people began to enter the stores just to pass time, as a leisure time activity followed by purchasing things out of want rather than mere necessity. David Lewis's stores (Liverpool in 1856, Manchester in 1880, Birmingham in 1885) led the way in including

\footnotetext{
${ }^{44}$ Chaney, ibid., p. 23.

${ }^{45}$ Hrant Pasdermadjian, The Department Store: Its Origins, Evolution and Economics, London: Arno Press, [1954]1976, p. 12.

${ }^{46}$ W. Hamish Fraser, The Coming of the Mass Market, 1850-1914, London and Basingstoke: Macmillan Press, 1981, p. 133.
} 
the working class in the customer profile of the department stores, announcing themselves as "Lewis's, the Friends of the People." This policy was apparently successful as, shortly after opening their Manchester store, they faced a court action "for creating a nuisance by causing crowds together."47

As mentioned earlier, the market place was a good place to socialize in the eighteenth century. Yet while people gathered around the commodities to socialize, commodities in the department stores surrounded customers till they surrendered. In a sense, as Schivelbusch explains regarding the department store, "the goods achieve more of their character as goods - their appearance as items of exchange value; one might say that their 'commodity-aesthetic' aspect becomes even more dominant."48 The problem with this aestheticization is that it "opens the social formation of meaning in an undetermined way, thereby encouraging the agents of aesthetic practice to perform the unceasing, autonomous and pleasure-motivated seeking process between a specific phenomenon and a non-existing overall concept which characterizes the process of aesthetic experience." 49

The department stores also helped move the means of subsistence further away from the consumer through a shift in "responsibility for packaging, stocking, evaluating

\footnotetext{
${ }^{47}$ Fraser, ibid., p. 132.

${ }^{48}$ Wolfgang Schivelbusch, The Railway Journey: The Industrialization of Time and Space in the 19th Century, Berkeley and Los Angeles: University of California Press, [1977]1986, p. 185.

${ }^{49}$ Henrik Kaare Nielsen, "The Aestheticization of the Public Sphere and Its Consequences for Democratic Political Culture," 2008, p. 7.
} 
and pricing goods from the retailers to wholesalers and manufacturers." 50 This shift made further alienation possible as the direct communication between consumer and producer was lost and had to be mediated through other means that could be easily manipulated. It was replaced, for example, by communication between customer and salesperson, which no longer concerned the production of the goods but their everyday life uses. Thus, a detachment from the sources began to rise irreversibly. Any price increases, to take an eighteenth-century problem for example, could no longer be blamed on the seller as the producer was no longer around (or, even if very close by, not visible any more).

What was visible, nevertheless, was the labour of store workers. Again, Pasdermadjian is proud to report how the "greater degree of division of labour, [the] use of relatively unqualified labour welded by the resources of organization and of the principles of delegation of skills into operating teams" made the department stores appear a model organization in the eyes of the public. ${ }^{51}$ The greater division of labour made it possible for such ventures to hire low-wage workers. London's first department store, Whiteley's, was opened in 1863 by William Whiteley, who identified himself as "The Universal Provider," claiming to supply anything "from a pin to an elephant at short notice." 52 His inspiration was the Great Exhibition of 1851 at Crystal Palace. By 1890, Whiteley was employing

\footnotetext{
${ }^{50}$ Chaney, “The Department Store as a Cultural Form,” 1983, p. 23.

${ }^{51}$ Pasdermadjian, The Department Store: Its Origins, Evolution and Economics, London: Arno Press, [1954]1976, p. 29

52 Richard S. Lambert, The Universal Provider: A Study of William Whiteley and the Rise of the London Department Store, London: George G. Harrap \& Co. Ltd, 1938.
} 
over 6,000 staff, accommodated on store-owned premises, and working a six-day week from 7 am until $11 \mathrm{pm} .^{53}$

The division of labour made it possible to employ unqualified workers, meaning they were not necessarily experts on the products they were marketing or responsible for, but could bring one quality: being presentable. Later in the century, when department stores were mushrooming, each shop's employees numbered in the thousands. With their presentable labour force, they became factories of cultural re-production, constantly producing life-styles. The organization of work had a mutual impact on the hundreds of employees presenting, not only the products and their labour power, but also their bodies, their manners, and attitudes. They were invited to become and intrinsic element of this gigantic décor, to become shareholders of this conspicuous luxury, but only while at work. They also carried that partnership into their life worlds when they left the store, albeit onesidedly. This in turn changed the social structure enormously. The re-defined interests of the proletariat now included part of this luxury and so-called comfort.

Because the centralization of market power in public life began in the eighteenth century, it is impossible to accept that the market colonized the life world as modern life itself was already being structured around the market. Similarly, it is inappropriate to consider the private spheres of the market as a twenty-first century phenomenon as the privatization of open market places began in England in the late seventeenth century. As Linebaugh explains, "since the 1670s the City of London had leased the markets to agents

\footnotetext{
${ }^{53}$ Christopher Hibbert, Ben Weinreb, John Keay, Julia Keay (Eds.), The London Encyclopedia, $3^{\text {rd }}$ Edition, London: Macmillan, [1983]2008, p. 1021.
} 
who regulated them and collected tolls in return for a rent to the City." 54 Agents collected rent from farmers while farmers increased their revenues by taking permanent stands. By the 1730s, however, the rents for the stands had increased so much that these small producers could no longer afford a permanent stand and were eventually driven out of the market. ${ }^{55}$ Instead, increasingly bigger producers took control of the markets. Linebaugh reports that, in 1730 , one dealer controlled twenty percent of the calf trade while two jobbers controlled Newgate Market. ${ }^{56}$ Yet the City authorities who had formerly regulated the open market did not intervene in what might be called violations of their regulations. Thus, they made centralization of the market, or the first condition of the market-publics as I call it, possible.

It is therefore important to note that cultural re-production in the market sphere is not a new or nineteenth-century phenomenon alone as its roots can be found in the late seventeenth century, and can be easily linked to the emergence of modern thought and the capitalist mode of production along with police power. In the next part, I discuss other areas of consumption and how they in turn effect the proletarian publics.

\section{Interventions into Proletarian Recreation}

The ruling classes had long been concerned with the leisure activities of the labouring classes, such as drinking, gambling, cock fighting, and horse-racing, and these

\footnotetext{
${ }^{54}$ Linebaugh, The London Hanged, 2003, p. 201.

${ }^{55}$ Linebaugh, ibid., p. 201.

${ }^{56}$ Linebaugh, ibid., p. 201.
} 
concerns were translated into legislative apparatus from time to time. ${ }^{57}$ However, starting with the late eighteenth century, legislation was enforced more severely in the everyday life of the working classes. The art of government of the self, involving a certain economy of time, was imposed in the name of regulating the everyday life of working populations. Interventions in non-working time and space were as harsh as those regarding working time and space. Referring to regulations in the first half of the century, M.J.D. Roberts notes that "the poor laws demoralized those who stayed at home; the vagrancy laws, by contrast, debauched those who joined the migratory labor market." Many popular recreations were criminalized while the Vagrancy Act of 1824 and others clearly specified the spaces of these various newly defined crimes as public spaces: public streets, public highways, public resorts, public places, public courts, public passages, and so on. As Storch reports, "there was a palpable narrowing of the limits of what would be tolerated in public and an increasing tendency to suspect the unforeseen, the unplanned, the unregulated and the unlicensed on the part of both local and national authorities." 58 The intersecting discourses of orderliness, prudence, self-control, and work served the aim of orchestrating the working classes in their non-working time and space. This orchestration involved objectifying the subordinated classes through diverse means of marginalization, criminalization, bureaucratization, and dividing practices.

\footnotetext{
${ }^{57}$ See Hunt, Governance of the Consuming Passions, 1996, pp.273-324. He clearly demonstrates that, from the early fourteenth century, sumptuary laws involve restrictions on how individuals dispose of their leisure time and of their income.
}

${ }^{58}$ Storch, Popular Culture and Customs, 1982, p. 14. 
According to Roberts, the implications of defining the legal borders of 'decent behaviour' and enforcing these legislative apparatuses (as in the Vagrancy Laws) were twofold: (1) it indicates a movement away from the communal and customary to the legal; (2) it sharpened the distinction between 'public' and 'private' spheres of activity, and identified the boundaries of the public sphere. ${ }^{59}$ The communal space-i.e. the streetswas redefined as 'public space,' which meant 'socially neutral space,' from which communal activities were displaced and gradually transferred to specialized, commercial venues, such as covered markets, theatres, or swimming baths. ${ }^{60}$ This made control and use of the public space a professional responsibility in the shadow of bureaucratization and commercialization. The bourgeois and market-public spheres operated hand-in-hand to institutionalize a set of interests for the proletariat: "a general interest, that need not be distorted by particular interests, guaranteed by an agreed rational approach to an objective order. ${ }^{\prime 61}$

In the early nineteenth century, the 'dangerous classes' rhetoric of the ruling classes was common. The basic danger was the lack of knowledge about these new settlers of the cities. Storch writes about a Liverpool businessman of the nineteenth century who said that his father "knew everyone of the hands whom he employed, they lived in their employer's cottages, close to his house and mill, within reach of the daily visits of his family." 62

\footnotetext{
${ }^{59}$ M.J.D. Roberts, "Public and private in early nineteenth-century London: The Vagrant Act of 1822 and Its Enforcement”, Social History 13:3, 1988, pp 273-294; p. 290.

${ }^{60}$ Roberts, ibid., pp. 293-294.

${ }^{61}$ Eric Laurier and Chris Philo, "“A parcel of muddling muckworms': revisiting Habermas and the English coffee-houses”, Social \& Cultural Geography vol.8 no.2, 2007, pp. 259-281; pp. 261-262.

${ }^{62}$ See Robert D. Storch, “The Plague of the Blue Locust: Police Reform and Popular Resistance in
} 
However, this was not the case for him as he did not know who his employees were. For this reason, one of the main objectives of the police became obtaining knowledge of working-class members and eliminating cultural diversity. The ruling classes were also aware that the working classes in the nineteenth century were not on the receiving end of outside interventions. ${ }^{63}$ The leisure activities of the poor therefore required vigilant surveillance so that workers would not dare to organize for their class causes. The target was the 'proletarian public sphere,' namely the field of working-class leisure and culture. The systematic efforts of bourgeoisie to subordinate the proletarian context of living was expanded and deepened over time. Working-class response to these approaches was resistance as "the police were unleashed upon many of the most vital popular habits and institutions." $" 64$

The objective was to build a more orderly, disciplined, regulated, and supervised society out of the culturally diverse habitants of the cities. The solutions aimed not so much at demolishing the circumstances creating poverty but rather at making "the poor bear their condition with even greater dignity." ${ }^{65}$ This, however, did not necessarily mean suppressing them in an unbounded way by the governing authorities. Rather, the goal was to make them subjects, carriers, and transmitters of the newly-emerging social order, increasingly less through violent enforcement and increasingly more through surveillance

Northern England, 1840-57”, in International Review of Social History, Vol. 20, 1975, pp. 63-64.

${ }^{63}$ Storch, "Introduction: Persistence and Change in Nineteenth-century Popular Culture," p. 5.

${ }^{64}$ Storch, "The Policeman as a Domestic Missionary: Urban Discipline and Popular Culture in Northern England, 1850-1880" in Journal of Social History, Vol. 9, 1976, p. 484.

${ }^{65}$ Stuart Hall, Chas Critcher, Tony Jefferson, John Clarke and Brian Roberts, Policing the Crisis: Mugging, the State, and Law and Order, London: Macmillan, 1978, p. x. 
tools of subordination. This was not the result of the central authority in England being “essentially benign" as Emsley would argue. ${ }^{66}$ Instead, the structural consequences of the new mode of production forced the ruling classes to take a strategic position of war. These consequences included the economic autonomy of wage labourers that led them to search for better life conditions; the unknown identity, culture, and background of each individual worker generating the masses; and the solidarity among the poor. The ruling classes had to struggle against these factors through an appropriate strategy while increasing industriousness of the working class at the same time.

It was clear in the nineteenth century that the industrial city separated class from class and eliminated older, more personal mechanisms of social control. "Unhappily," Wrote a Liverpool businessman in 1867 ,

it is true that, with the growth of wealth and population, the wall of moral separation appears to have become broader, higher and more impassable. The rich see less of the poor than they used to do, know less of their habits, their feelings, and their wants. So far as our towns are concerned, the cases are few in which there is any personal tie between rich and poor-any recognition of a connexion that does not end with working hours, or of any claim on an individual for anything besides fair

\footnotetext{
${ }^{66}$ Clive Emsley states that the development of professional police forces in England in the nineteenth century was facilitated "first, by a general perception of central authority in Englandwhat some would term 'the state' - as essentially benign, and second, by the fact that over the last two centuries, and in contrast to the other major powers in Europe, the constitutional structure in England has been stable." See The English Police: A Political and Social History, London \& New York: Longman, 1996, p. 7 (emphasis is mine).
} 
wages and honest work. The subdivision of labour severs the personal connexion which established an evident mutual claim between master and servant. ${ }^{67}$

The reform of popular culture thus includes the ruling classes' systematic attempts to eliminate the diverse attitudes, values, and practices of working classes. The ruling classes' increasing interest in more formal study of popular customs in the late eighteenth and early nineteenth centuries resulted from seeing popular values, rituals, customary practices, crowds, and politics as problems, so in turn they had to construct these as targets for governance.

Storch explains: "the object was to create a new kind of urban paternalism which would bypass, ignore and refuse to compromise with the old popular culture." ${ }^{68}$ Thus, it can be claimed that, although the structure was built on a system of natural freedoms and maturity of human beings, what was still at hand was this paternalism. Police power was re-building paternalism, the power of which still emanated from tradition while also relying on scientific and legal rationality. This paternalistic mentality, deriving from its feudal or even ancient roots, has never been left behind. During the Enlightenment, this paternalistic idea was refurbished and put into the service of modernity.

It is understandable then to see an enthusiasm among the ruling classes by the early 1860s claiming responsibility for 'improving' the lower orders of society:

\footnotetext{
${ }^{67}$ Storch, "The Plague of the Blue Locust," 1981, p. 63.

${ }^{68}$ Storch, "Introduction: Persistence and Change in Nineteenth-century Popular Culture," 1982, p. 3.
} 
with all our boasted improvements, the mind, taste, and feelings of vast masses of the people are as yet scarcely touched, and remain pretty much what they were in days gone by. How to reach these masses with your manifold agencies is a problem, of which no one ... has been able to give us a satisfactory solution. You establish schools - they are indifferent ... You publish cheap books - they will neither purchase nor peruse them ... Yet, in spite of everything, habits the most groveling continue flourish. In the midst of civilization ... there is ... a kind of barbarismnot abject and poverty-struck, but vigorous and self-willed. ${ }^{69}$

The ruling classes also complained that there were very few amusement spaces for working-class people in the cities although there were already enough alehouses, brothels, and coffee houses for workers to enjoy. As Storch rightly notes, there were "very little elevating, rational, politically neutral, instructive activities to engage the workers in bigger towns." ${ }^{" 70}$ Left alone to entertain themselves, the poor became violent and dangerous so the ruling classes had to define what was in the interest of the proletariat and create a sphere in which the proletariat could satisfy these interests. Colquhoun defined one feature of the police science as creating better recreation opportunities for the public:

it is no inconsiderable feature in the science of Police to encourage, protect, and control such as tend to innocent recreation, to preserve the good humour of the Public, and to give the minds of the people a right bias ... Since recreation is necessary to Civilised Society, all Public Exhibitions should be rendered

\footnotetext{
${ }^{69}$ Quoted in Storch, “The Problem of Working-class Leisure,” 1977, p. 152.

${ }^{70}$ Storch, “The Problem of Working-class Leisure,” 1977, p. 153.
} 
subservient to improvement of morals, and to the means of infusing into the mind a love of the Constitution, and a reverence and respect for the Laws ... How superior this to the odious practice of besotting themselves in Ale houses, hatching seditious and treasonable designs, or engaging in pursuits of vilest profligacy, destructive to health and morals. ${ }^{71}$

Colquhoun's hostility towards the proletarian way of life come into the open once again in this quote. Nevertheless, it was not unusual or new for the ruling classes to complain about how working classes spend their leisure time, as Hunt demonstrated in great detail in his study of the sumptuary laws: "restrictions on how individuals dispose of their leisure time and of their income" were results of a concern of more time-wasting than gambling and drinking in themselves. ${ }^{72}$

One of the potentially most revolutionary times and spaces in which the proletariat could organize their horizon of experience was the space of recreation (or leisure time). I argue that the market and police joint action de-formed and re-formed this space as the kind of public sphere the ruling classes wanted to govern. This space was re-defined as an investment opportunity for capital holders and a target of governance for the ruling classes. Thus, opportunities for access to 'natural' recreation areas in metropolitan London gradually decreased. For example, male working-class youth were deprived of their traditional river bathing by the private property of canal companies as well as regulated

\footnotetext{
${ }^{71}$ Colquhoun, The Police of the Metropolis, 1796, pp. 347-348.

${ }^{72}$ Hunt, Governance of the Consuming Passions: A History of Sumptuary Law, London: Palgrave MacMillan, 1996, pp. 273-295.
} 
public parks. ${ }^{73}$ The need for regulation voiced by the respectable middle classes for acceptable working-class recreational services was reflected in regulations and massproduction in the recreational areas of beerhouses, music halls, sports, tea houses, cycling, reading materials, and excursions. ${ }^{74}$ However, the market-police joint action did not completely uproot the old leisure activities because, as Storch indicates, "to have done so would have provoked too much resistance." 75 Instead, those activities that were tolerated or encouraged by the ruling classes were gradually "transferred from public space to specialized and more controllable venues - covered markets, theatres, swimming baths and the like." 76

Thus, the working classes' public space was shifted towards market-publics. To that end, various governing technologies were developed, whereby the police and market forces used their joint capacities to build market-publics inclusive of the proletariat insofar as they comply with their redefined interests. Wine and beer houses, music halls, dancing saloons, and open-air sports were problematized and regulated through a series of licensing acts throughout the second half of the nineteenth century. These licensing acts placed police at the centre of inspecting and monitoring proletarian recreation while regulating

\footnotetext{
${ }^{73}$ M.J.D. Roberts, "Public and private in early nineteenth-century London: The Vagrant Act of 1822 and Its Enforcement," Social History 13:3, 1988, pp. 273-294.

${ }^{74} \mathrm{~W}$. Hamish Fraser sees these categories as the most successful new entertainment sectors in the second half of the nineteenth century in London. See The Coming of the Mass Market, 1850-1914, London and Basingstoke: Macmillan Press, 1981, p. 209-231.

${ }^{75}$ Storch, "Introduction: Persistence and Change in Nineteenth-Century Popular Culture," 1982, p. 15.

${ }^{76}$ M.J.D. Roberts, "Public and private in early nineteenth-century London: The Vagrant Act of 1822 and Its Enforcement”, Social History 13:3, pp 273-294.
} 
their consumption patterns. ${ }^{77}$ As Valverde notes, licensing governs "the times and opportunities and places in which problematic activities occur."78 In this sense, it shapes the sphere of action, not by touching and punishing people, but by diminishing opportunities for non-inscribed action.

\section{Conclusion}

Above all, one of the 'effects' of police power was to commodify the proletarian public sphere. The commodity character of the (bourgeois) public sphere in general and the proletarian public sphere in particular rely on value abstraction. The sphere of action is no longer determined through actual people acting in that sphere but through legislation, licensing, uniformed police forces, specific street design, and so on. All these serve as a kind of value abstraction that finds its meaning in the modern social order as it equips the public sphere with the ability to conceal its process of production. Moreover, it equips the physical sphere of action with charming places and materials that easily manipulate the demands and interests of the working classes.

Although workers do contribute to its production, the public sphere rarely provides use-value for working-class people. Commodification implies a forgetting of the production process of the end product. From within Marxist theory, it goes without saying that this process of forgetting alienates the producers from their own field of action. It also has another crucial impact: taking the way things are for granted as normalization of the

\footnotetext{
${ }^{77}$ Storch, "Introduction: Persistence and Change in Nineteenth-Century Popular Culture," 1982, p. 15.

${ }^{78}$ Mariana Valverde, "Police science, British style: pub licensing and knowledges of urban disorder," Economy and Society 32:2, 2003, pp. 234-252, p. 244.
} 
commodified public sphere becomes inevitable. "All reification is a forgetting,"79 says Adorno, while Ericson reminds us that "we tend to forget that the modern policing system has been in existence only for 150 years." ${ }^{~} 80$ The history of capitalism has in this sense been the history of forgetting this contradictory nature of the public sphere once it had been produced by police power, starting with the mid-seventeenth century.

79 Adorno, "Letter to Benjamin, 29 February 1940" in Walter Benjamin and Theodor Adorno, The Complete Correspondence, 1928-1940, New York: Polity Press, 2000, p. 321.

${ }^{80}$ Richard V. Ericson, "The Police as Reproducers of Order" in K.R.E. McCormick and L.A. Visano (eds.), Understanding Policing, Toronto: Canadian Scholars' Press, 1992, p. 163. 


\section{CONCLUSION:}

\section{REMARKS ON THE CONSOLIDATION OF THE PUBLIC SPHERE}

The much vaunted mellowing of manners ... and the cozy security of daily life that follows have their price. A price which we, dwellers in the house of modernity, may be called to pay at any time. Or made to pay, without being called first.

Zygmunt Bauman, Modernity and the Holocaust, 1989

It has never been as clear as it is today that the rules and procedures that presumably enable some at least to exercise their democratic rights and freedoms are irrelevant when the needs of capital accumulation are at stake. While the executive power of governments expands more and more, it is important to keep Bauman's reminder in mind and articulate how we have become subject to and subjects of the "cozy security of daily life." Regulation of the spheres of action has always been the main concern of ruling authorities while the history of modern capitalism has been a history of attempts to (re)produce and thus commodify (as no other production is possible under capitalism) a single, homogenized public sphere. In this, police power has made it possible to form, deform, and re-form the spheres within which the "general horizon of social experience" is supposedly organized, i.e. the public spheres.

The internal contradictions of modernity in general, and bourgeois democracy in particular facilitate the belief in the revolutionary potential of the public sphere in general, and proletarian public sphere in particular. However, in this thesis I have tried to show that 
this potential had decreased significantly by the end of the nineteenth century due to interventions in the proletarian way of life to make it resemble the bourgeois way of life and sink it into the charming sea of market-based values. Police served to veil the manifest class nature of governance as did the discourse on public good. Although 'governing with the people for the people by the people' may remain as a promise of republicanism, it has become more of an ideal than a reality under capitalism. This makes it important to note how this potential was minimized and how the working classes fought back against these changes. The modern projects of police and the public have combined to shape the modern idea of state formation and politics, thereby constructing an economically productive but politically limited order.

Both police and the public are central to contemporary discussions about security fetishism. They are either discussed from the angle of the police hindering public relations or from the angle of privatization, as if the privatization of public spaces through private security forces or the privatization of the public police is the main issue. My inquiry here counters both lines of discussion about police and the public because I have argued that both police and the public are indeed projects of modernity that have always been implemented hand in hand to create order in bourgeois societies. Thus, while examining the history of police theory alongside practical police projects within the development of the public sphere, I have tried to understand the supposed contradiction between modern ideals and capitalist realities. The public was operationalized in defining modern politics, particularly in differentiating political, social, and economic areas from each other. Accordingly, this thesis aimed to develop a historical reading of the political public sphere 
from a sociological perspective, in an attempt to trespass across the boundaries between the social, political, and economic.

In contrast to these contemporary discussions, this thesis operationalized the separation between these three areas as a methodological tool, defining a triangle within which the relationship of police to the public sphere was analyzed. Commencing with the mid-seventeenth century, I have first noted the 'reinvention of politics' whereby police science represented new modes of experiences, power relations, and knowledge production, first as a method to centralize governmental power, then as a strategy to exercise power over each and every subject. I have then noted that police science was also significant for sustaining and expanding capitalist relations of exploitation, which I have called 're-creation of political economy,' expanding the scope of the economy from households to the whole nation. I have finally noted that the police project also became a preliminary mechanism for homogenizing the cultural and moral differences amongst the working classes while maintaining the life-style distinctions between the bourgeoisie and the proletariat. I have called this the 're-formation of popular culture.' This created a conceptual triangle to work with: reinvented politics, recreated economy, and reformed popular culture.

I also problematized that the concept of police was, to a great extent, defined and projected on material bases, as it had been since the work of early modern scholars, whereas the concept of the public, although as widely-used as the concept of police, was always mentioned in passing, and almost always as an abstraction referring to different groups of people, places, or things, depending on the context. While the concept of police was used 
along with the public, as in public policy or the public police, the public in such phrases never received such nuanced treatment as a defining concept or addressee; instead, it was defined and re-defined in every public policy or by every police action. In this thesis, I have argued that the public and consecutive public spheres have been materialized as governable targets through police actions. The 'price' of enjoying public life or participating in political action in the public sphere has therefore been to either comply with or resist police power in general, and to endure police actions in particular. It is therefore important to look at alternative ways of organizing proletarian experience in the proletarian public. One alternative might be to adopt the feminist motto that the "personal is political" in order to highlight the not necessarily economic but certainly moral and cultural value-based motivations that bring the working classes together. This counters the police power's way of making the public from above.

I illustrated the transition to a new mode of power in the late seventeenth century, namely police power, in parallel with the transition to the new capitalist mode of production. I have demonstrated the construction of the public through discursive and nondiscursive practices, paying attention to the emergence of the proletariat as a class in England in the late eighteenth century, and to the consecutive proletarian publics as revolutionary seedbeds in the early nineteenth century. I have then demonstrated how this revolutionary potential declined drastically through market-police joint action by the end of the nineteenth century once the structural formation of the bourgeois public sphere had been completed. I have concluded that it was not the police who were the repressive state apparatus oppressing productive forces through violence. It was not, for example, 
newspapers or other media brainwashing the workers as ideological state apparatuses. Instead, it was the public-making potential of police power that not only made workers accept their new conditions but also prescribed the ways to oppose or resist in a predictable, reversible, non-anonymous manner. That is, the sphere of the public appeared along with its tools, possible targets, and methods of politics.

The realization of the project of the bourgeois public sphere (albeit an incomplete and constantly on-going project) eliminated the proletariat's revolutionary potential and forced politics to become predictable and reformist, with prescribed methods that could be easily repealed during a crisis of capitalism. The police, who played the major role in establishing the public sphere, could at any time make use of the pro-actively collected information about the opposition and their projects. With these considerations in mind, in Chapter One, I revealed the significance of taking police and the public into account together to understand the modern state formation. I identified the puzzle and reviewed the literature on police and the public. While exploring the scale, scope, and limitations of my project, I listed the main principles I relied on in researching and writing about this subject, highlighting that it involves both the history of ideas and social history while not locating itself within either field but rather in social theory. In doing so, I clarified how I drew on both Marx and Foucault in accepting class structure and power relations in tandem.

In Chapter Two, I discussed how to use the concept of the public sphere for an historical understanding of the proletarian context of life. In so doing, I identified the problems in the various definitions of the term before re-contextualizing the term to include diverse publics and representing the interconnectedness of the social and the political 
through the concept of the public sphere. The primary task of the chapter was to demystify the concept of the public to make it more analytically useful. In Chapter Three, I looked at the history of police as an Enlightenment project with a focus on its concerns for mass education, observation, scientification, regulation, emancipation, and totalization. I argued that eighteenth-century police science re-invented both police and politics by replacing the Aristotelian method with a mechanistic one. I claimed that the police school reduced politics to political economy so that all issues concerning the public became linked to economy.

In Chapter Four, I emphasized that the police project has been a major component of modern state formation through which the spheres of political, economic, and sociocultural action have been formed. The modern era signifies a great breaking-up with the immediate means of material and cultural subsistence for the masses through diverse mechanisms. The most obvious of mechanism is primitive accumulation, which stripped people of their common rights. In this chapter, I made the case that in the context of this rupture, the function of police has become to mediate between the masses and their means of subsistence (which are the means to material, cultural, religious, sanitary, and even linguistic subsistence) by organizing spaces of action, drawing limits, expanding opportunities, controlling distribution, reinforcing production, securing communication, and so on. At the same time, public-ization (in the sense of nationalization) and privatization displaced the commons, and common rights and practices.

In Chapter Five, I historicized the term the 'proletarian public sphere' in order to demonstrate a relationship between the emergence of proletarian class consciousness and 
the modern police force. I argued that the proletarian public was as much made from above through police practices as it was from below through class ways of action. Some became particular to the proletariat whereas some were mere simulations of the bourgeois public sphere. I argued in this chapter that the public (and the public sphere) as targets of government are made possible through implementing police power, and this is no clearer than in the emergence of the proletarian public sphere. The ruling class anxiety of the late eighteenth and early nineteenth century defined in detail what would be tolerated in public through newly-created police offenses, including those regulating newspapers, moral tracts, foot patrols, and licensing. These were all contracted over the long term to be more closely supervised and regulated in coordination by the state and non-state authorities.

In Chapter Six, I looked at market-driven policies and police actions to prove two claims. The first was that, increasingly during the second half of the nineteenth century, the proletarian publics suffered intervention and deformation that was implemented through a joint market-police action. My second claim was that the market space should be theorized and understood as a public sphere in which the commodity-like character of the public sphere actually materializes. To illustrate, I discussed the organization, regulation, and projection of proletarian leisure activities. I also used the first department stores, introduced in the nineteenth century, to demonstrate how new relations of production were translated into changing consumption patterns, and how police power was involved in these patterns.

The main conclusions to be drawn from this thesis can be listed as follows: 
First. Modernity and capitalism go hand in hand. A critique of modernity cannot exclude a critique of capitalism and vice versa. The categories that modernity is built on are the categories that are conditio sine qua non for capitalism. It is therefore crucial to actively critique and weaken the categories of modernity to create effective counter-hegemonic strategies.

Second. This need is the clearest when it comes to two crucial building blocks of both modernity and capitalism: police power and the public (sphere). The discursively constructed category of 'the public' impacted the subsequent practices of agencies of governments. The construction process and the governing process in terms of orchestrating diverse subjects into becoming the public was achieved through police power: one that supervises, hierarchizes, orders, disciplines, encloses, demarcates, and totalizes while individualizing. The public, in this sense, was not limited to the procedures of modern political institutions, as argued by liberal theorists, but needed to involve other spheres as targets to be governed by the dispersed police power. Thus, a clear theoretical definition of the public has to refer to both the proletarian public and market-publics. That is, we can no longer keep talking about a single public sphere while multiple public spheres, of which the bourgeois, proletariat, and market-publics are the most crucial, constantly construct through police power diverse subjects as the public.

Third. The public and the public sphere are made possible through police power. The main target of police power is to generate publics in order to put exploitation of labour in order. That is, the police is the great mediator of the public. Where there is police, there is public; where there is public, there is police; where there is public and police, there is constant 
exploitation of labour. Thus, exploitation of labour power and police power are firmly related.

Fourth. There are no commons now but publics so our means of resistance cannot be built on some idealized commons because the production of space as the public sphere and subjects as the public has long eliminated any possibility of returning to the commons. What is called or being re-claimed as the commons has already been subjected to the procedures of the public sphere. In the condition of the commons, those who benefitted from the land, for example, were the ones who governed the land. However, this is no longer possible because, even if those who use the land now may claim to govern it, they will always get trapped in the procedures of the bourgeois public sphere and commodification of the market-publics. The tools to govern, not only material tools but also cultural, moral, social, and intellectual tools, no longer belong to the commoners. It is impossible to create an emancipated space, free from police power. If not the bourgeois public sphere's police, the proletariat's own police power (constantly calling for lawful, procedural, disciplined action) will prevent this. The commons cannot provide an effective alternative for revolutionary action. All commons have now been made public, hence commodified. And commodification, through making public in order to make the public, functions no differently than the commodification of goods and services: it is similarly alienating, reifying, and open to fetishizing.

Fifth. Regarding previous point, this thesis also concludes that the public relevance of market-publics should be placed at the forefront in attempts to theorize and take political action. Taking everyday exploitative mechanisms and their structural consequences as their 
raw material, market-publics process them, congeal them in commodities, deem them private, and then make them publicly available again while making the public of consumers - each of whom consider themselves special. Their ability to take what is public and turn it into private gain is too important an issue for the public to leave the analysis only in the hands of private financial analysts, for example. Market-publics should first be reclaimed theoretically in order to find effective ways to reveal their public relevance and challenge them in practice.

Sixth. This thesis also suggests that the illusion of separated spheres of the private and public must be rejected because, as with all binaries, it limits the analysis from the start.

Seventh. The de-commodification of the public sphere ideal should start by accepting the assumptions listed here and acknowledging that it is actually a product of police power.

Eight. I should also highlight that it is not that the proletariat 'emulate' the bourgeoisie, in Veblen's terms, when it comes to the proletarian public sphere. It is rather that no other space for political action was left for the proletariat to begin something new. The space for political action was defined through police power's mechanisms of consent and coercion as the public sphere.

Ninth. It is therefore easy to conclude that the rights and freedoms that the proletariat have gained over time exist despite modern police power based on a capitalist mode of production rather than because of it.

Tenth. An initial underlying assumption of this thesis also provides one of its conclusions: "theory is history and history is theory." I believe this thesis has demonstrated this through 
its theorizing based on historical research while simultaneously questioning the theoretical relevance of specific historical materials. However, a thorough historical research is yet to be completed on the subjects discussed here.

More than any of these conclusions, I believe the significance of this thesis lies in the path it opens for further research, particularly in an interdisciplinary field of study. Besides the study's main themes, research in socio-legal studies, social media, publicprivate policing, communication, social movements, and working class politics could benefit from the categories used in this thesis. International relations theory, in which significant effort is used to differentiate the social from the political, and military war power from police power could also draw on the main assumptions of this thesis.

I strongly believe that the theoretical framework underlying this thesis will particularly benefit three areas of research, and a future study based on this thesis would also benefit greatly from these three fields. First, it could open a new path for feminist social history studies regarding state formation in capitalist societies as it directs attention to the public relevance of what has, for so long, been deemed private, conventionally the sphere of women. Second, I think this thesis encourages further research that takes into account the colonizing nature of the projects of police and the public in postcolonial studies. Such work could draw on the main points in this thesis in the search for decolonizing practices that should, according to this thesis, start from the so-called public sphere. Third, I believe this thesis paves a way for further research based in critical urban studies, which spatializes the public sphere and treats it as a socio-spatial materiality. At the same time, these three fields of study also represent areas of improvement for this thesis 
since engagement with these three literatures is necessary for future research in order to develop further the arguments presented in this thesis. 


\section{BIBLIOGRAPHY}

Adorno, Theodor W. 2008. The Culture Industry. J. M. Bernstein (Ed.). London and New York: Routledge.

Anderson, Benedict. [1982] 2006. The Imagined Communities. New York: Verso.

Anderson, Perry. 1979. Lineages of the Absolutist State. New York: Verso.

Anderson, Perry. 1984. In the Tracks of Historical Materialism. London: Verso.

Arendt, Hannah. [1950s] 2002. Karl Marx and the Tradition of Western Political Thought. Social Research. 69:2, pp. 273-320.

Arendt, Hannah. [1958] 1998. The Human Condition. Chicago and London: University of Chicago Press.

Arendt, Hannah. [1963] 2006. On Revolution. New York: Penguin Books.

Aristotle. 1976. The Nicomachean Ethics. J.A.K. Thomson (Trans.). London: Penguin Books.

Asquith, Ivon. 1978. The Structure, Ownership and Control of the Press, 1780-1855. In Tustall, Jeremy (Ed.). Newspaper History: from the Seventeenth Century to the Present Day. London: Constable, pp. 98-116.

Bailey, Peter. 1978. Leisure and Class in Victorian England: Rational Recreation and the Contest for Control, 1830-1885. London: Routledge \& Kegan Paul.

Bailey, Peter. 1979. "Will the Real Bill Banks Please Stand Up?” Towards a Role Analysis of Mid-Victorian Working-Class Respectability. Journal of Social History 12:3, pp. 336353.

Bailey, Peter. Custom, Capital and Culture in the Victorian Music Hall. In Storch Robert D. (Ed.). Popular Culture and Custom in Nineteenth-Century England. London: Croom Helm Ltd, pp. 180-208.

Baridon, Michel. 2008. A History of the Gardens of Versailles. Adrianne Mason (Trans.). 
Philadelphia: Pennsylvania University Press.

Barrie, David G. 2008. Patrick Colquhoun, the Scottish Enlightenment and Police Reform in Glasgow in the late Eighteenth Century. Crime, History and Societies 12:2, pp. 5979.

Barry, Andrew. 1996. Lines of Communication and Spaces of Rule. In Barry, Andrew, Osborne, Thomas and Rose, Nicholas (Eds.). Foucault and Political Reason: Liberalism, Neo-Liberalism and Rationalities of Government. Chicago: University of Chicago Press, pp. 123-142.

Bauman, Zygmunt. 1987. Legislators and Interpreters: on modernity, post-modernity, and intellectuals. Cambridge: Polity Press.

Bauman, Zygmunt. 1989. Modernity and the Holocaust. Cambridge: Polity.

Bayley, David H. and Clifford D. Shearing. 1996. The Future of Policing. Law and Society Review 30:3, pp. 585-606.

Beccaria, Cesare. 1996. Of Crimes and Punishments. Jane Grigson (Trans.). New York: Marsilio Publishers.

Beccaria, Cesare. 1775. A Discourse on Public Economy and Commerce. http://socserv.mcmaster.ca/econ/ugcm/3113/beccaria/pubecon (reached on July 14, 2015).

Beck, Ulrich. 1997. The Reinvention of Politics. Oxford: Blackwell Publishers.

Behagg, Clive. 1982. Secrecy, Ritual and Folk Violence: The Opacity of the Workplace in the First Half of the Nineteenth Century. In Storch Robert D. (Ed.). Popular Culture and Custom in Nineteenth-Century England. London: Croom Helm Ltd, pp. 154-179.

Belchem, John C. 1982. 1848: Feargus O'Connor and the Collapse of the Mass Platform. In Epstein, James and Thompson, Dorothy (Eds.). The Chartist Experience: Studies in Working-Class Radicalism and Culture, 1830-1860. London: MacMillan Publishers Ltd, pp. 269-310.

Belchem, John C. 1988. Radical Language and Ideology in Early Nineteenth-Century 
England: The Challenge of the Platform. Albion: A Quarterly Journal Concerned with British Studies 20:2, pp. 247-259.

Benchimol, Alex and Willy Maley. 2007. Introduction: circling the public sphere. In Benchimol and Maley (Eds.). Spheres of Influence: Intellectual and Cultural Publics from Shakespeare to Habermas. Oxford: Peter Lang AG.

Benjamin, Walter. [1935]1968. Paris - Capital of the Nineteenth Century. New Left Review 1: 48, pp. 77-88.

Benjamin, Walter. 1968. The Illuminations. Hannah Arendt (Ed.). New York: Harcourt, Brace and World.

Bennett, Jennifer. 1982. The London Democratic Association 1837-1841: A Study in London's Radicalism. In Epstein, James and Thompson, Dorothy (Eds.). The Chartist Experience: Studies in Working-Class Radicalism and Culture, 1830-1860. London: MacMillan Publishers Ltd, pp. 87-119.

Bentham, Jeremy. 1995. The Panopticon Writings. Miran Bozovic (Ed.). London: Verso.

Bernstein, Richard J. 2012. The Normative Core of the Public Sphere. Political Theory 40:6, pp. 767-778.

Berridge, Virginia. 1978. Popular Sunday Papers and Mid-Victorian Society. In Tustall, Jeremy (Ed.). Newspaper History: from the Seventeenth Century to the Present Day. London: Constable, pp. 247-264.

Bourdieu, Pierre. 1984. Distinction: A Social Critique of the Judgement of Taste. London and New York: Routledge.

Bourdieu, Pierre. 1989. Social Space and Symbolic Power. Sociological Theory 7:1, pp. 14-25.

Bourdieu, Pierre. 2004. The Mystery of the Ministry: From Particular Wills to the General Will. Constellations 11:1, pp. 37-43.

Bowes, Stuart. 1966. The Police and Civil Liberties. London: Lawrence and Wishart. 
Boyce, George. 1978. The Fourth Estate: The Reappraisal of a Concept. In Tustall, Jeremy (Ed.). Newspaper History: from the Seventeenth Century to the Present Day. London: Constable, pp. 19-40.

Breton, Rob. 2009. Genre in the Chartist Period. In Krishnamurthy, Aruna (Ed.). The Working-Class Intellectual in Eighteenth- and Nineteenth-Century Britain. Surrey: Ashgate Publishing Company, pp. 109-127.

Breton, Rob. 2011. Violence and the Radical Imagination. Victorian Periodicals Review 44:1, pp. 24-41.

Brodeur, Jean-Paul. 2010. The Policing Web. Oxford: Oxford University Press.

Brodie, Marc. 2003. Free Trade and Cheap Theatre: Sources of Politics for the NineteenthCentury London Poor. Social History 28:3, pp. 346-360.

Burchell, Graham. 1991. Peculiar Interests: Civil Society and Governing 'The System of Natural Liberty.' In Burchell, Graham, Gordon, Colin and Miller, Peter (Eds.). The Foucault Effect: Studies in Governmentality. Chicago: University of Chicago Press, pp. 119-150.

Burke, Edmund. [1774] (2005). Speech to the Electors of Bristol, On His Being Declared by the Sheriffs Duly Elected One of the Representatives in Parliament for that City. In The Project Gutenberg E-Book. The Works of the Right Honourable Edmund Burke vol. 2 (of 12). Retrieved on 10.11.2012. http://www.gutenberg.org/files/15198/15198h/15198-h.htm.

Burke, Peter. [1978] 2009 (third edition). Popular Culture in Early Modern Europe. Surrey: Ashgate Publishing Ltd.

Cain, Maureen and Alan Hunt. 1979. Marx and Engels on Law. London: Academic Press. Calhoun, Craig. 1992. Introduction: Habermas and the Public Sphere. In Calhoun, Craig (Ed.). Habermas and the Public Sphere. Cambridge and London: The MIT Press.

Calhoun, Craig. 1993. Civil Society and the Public Sphere. Public Culture 5, pp. 267-280. Calhoun, Craig. 2001. Civil Society/Public Sphere: History of the Concept(s). In 
International Encyclopedia of the Social and Behavioral Sciences. Amsterdam: Elsevier.

Calhoun, Craig. 2004. Public. In Bennett, T. and Grossberg, L. (Eds.). New Keywords. Buckingham: Open University Press.

Calhoun, Craig and Michael McQuarrie. 2007. Public Discourse and Political Experience: T. J. Wooler and Transformations of the Public Sphere in Early 19th Century Britain. In A. Benchimol and W. Maley (Eds.). Spheres of Influence: Intellectual and Cultural Publics from Shakespeare to Habermas. Oxford: Peter Lang, pp. 197-234.

Carlisle, Janice. 2012. Picturing Reform in Victorian Britain. Cambridge: Cambridge University Press.

Carr, Edward Hallett. 1962. What is History? London: MacMillan \& Co Ltd.

Center for Research on Criminal Justice. 1977. The Iron Fist and the Velvet Glove: An Analysis of the U.S. Police. Berkeley: Center for Research on Criminal Justice.

Chaney, David. 1983. The Department Store as a Cultural Form. Theory, Culture and Society 1:3, pp. 22-31.

Colquhoun, Patrick. 1795. Treatise on the Police of the Metropolis. London: Mawman.

Colquhoun, Patrick. 1800. A Treatise on the Commerce and Police of the River Thames. London: Mawman.

Cone, Carl B. [1968]2010. The English Jacobins: reformers in late 18th century England, New Brunswick and London: Transaction Publishers.

Corrigan, Philip and Sayer, Derek. 1985. The Great Arch: English State Formation as Cultural Revolution. Oxford: Basil Blackwell Ltd.

Costas, Douzinas, Slavoj Žižek, and Alex Taek-Gwang Lee (ed.). 2010. The Idea of Communism. London, New York: Verso.

Cressy. David. 1986. Kinship and Kin Interaction in Early Modern England. Past and Present 113.

Critchley, Thomas Alan. 1967. A History of Police in England and Wales, 900-1966. 
London: Constable.

Croll, Andy. 1999. Street Disorder, Surveillance and Shame: Regulating Behaviour in the Public Spaces of the Late Victorian British Town. Social History 24:3, pp. 250-268.

Crook, Tom. 2007. Sanitary Inspection and the Public Sphere in Late Victorian and Early Edwardian Britain: A Case Study in Liberal Governance. Social History 32:4, pp. 369393.

Cunningham, Hugh. 1977. The Metropolitan Fairs: A Case Study in the Social Control of Leisure. In Donajgrodzki, A.P. (Ed.). Social Control in Nineteenth Century Britain. London: Croom Helm Ltd, pp. 163-184.

Curran, James. 1978. The Press as an Agency of Social Control: A Historical Perspective. In Tustall, Jeremy (Ed.). Newspaper History: from the Seventeenth Century to the Present Day. London: Constable, pp. 51-75.

Curtis, T. C. and Speck, W. A. 1976. The Societies for the Reformation of Manners: A Case Study in the Theory and Practice of Moral Reform. Literature and History 3, pp. 45-64. Dahlberg, Lincoln. 2005. The Habermasian Public Sphere: Taking Difference Seriously? Theory and Society 34:2, pp. 111-136.

Dean, Mitchell. 1991. The Constitution of Poverty: Toward a Genealogy of Liberal Governance. London \& New York: Routledge.

Dewey, John. [1946] 2006. The Public and its Problems. Swallow Press.

Dietz, Mary G. 1995. Feminist Receptions of Hannah Arendt. In Honig, Bonnie (Ed.). Feminist Interpretations of Hannah Arendt. Pennsylvania: The Pennsylvania State University Press.

Donajgrodzki, A.P. 1977. 'Social Police' and the Bureaucratic Elite: A Vision of Order in the Age of Reform. In Donajgrodzki, A.P. (Ed.). Social Control in Nineteenth Century Britain. London: Croom Helm Ltd, pp. 51-76.

Donajgrodzki, A.P. 1977. Introduction. In Donajgrodzki, A.P. (Ed.). Social Control in Nineteenth Century Britain. London: Croom Helm Ltd, pp. 9-26. 
Donzelot, Jacques. 1980. The Policing of Families: Welfare versus the State. Robert Hurley (Trans.). London: Hutchinson \& Co. Ltd.

Dröge, Franz. 1983. Social Knowledge and the Mediation of Knowledge in Bourgeois Society. Robert Peck (Trans.). Media, Culture and Society 5, pp. 49-63.

Dubber, Markus D. 2005. The Police Power: Patriarchy and the Foundations of American Government. New York: Columbia University Press.

Dubber, Markus D. 2006. The New Police Science and the Police Power Model of the Criminal Process. In Markus D. Dubber and Mariana Valverde (Eds.). The New Police Science: The Police Power in Domestic and International Governance. Stanford: Stanford University Press.

Eick, Volker and Kendra Briken. 2013. Urban (In)Security: Policing the Neoliberal Crisis. Ottawa: Red Quill Books.

Eisenstein, Zillah (Ed.). 1979. Capitalist Patriarchy and the Case for Socialist Feminism. Monthly Review Press.

Eley, Geoff. 1990. Edward Thompson, Social History and Political Culture: The Making of a Working-class Public, 1780-1850. In Kaye, Harvey J. and McClelland, Keith (Eds.) E.P. Thompson: Critical Perspectives. Philadelphia: Temple University Press, pp. 5078.

Emsley, Clive. 1988. Crime in Nineteenth-Century Britain. History Today 38:4, p. 40.

Emsley, Clive. 1996. The English Police: A Political and Social History. London and New York: Longman.

Emsley, Clive. 2009. The Great British Bobby: A History of British Policing from the 18th Century to the Present. London: Quercus.

Engels, Fredrich. 1969. Anti-Dühring: Herr Eugen Dühring's Revolution in Science. Moscow: Progress Publishers.

Engels, Fredrich. 2009. The Condition of the Working Class in England. London: Penguin Books. 
Ericson, Richard V. 1992. The Police as Reproducers of Order. In K.R.E. McCormick and L.A. Visano (Eds.). Understanding Policing. Toronto: Canadian Scholars' Press, pp. $163-208$.

Ericson, Richard and K. Haggerty. 1997. Policing Risk Society. Oxford: Oxford University Press.

Foster, John. 1974. Class Struggle and the Industrial Revolution: Early Industrial Capitalism in Three English Towns. London: Methuen \& Co Ltd.

Foucault, Michel. 1980. Two Lectures. In Colin Gordon (Ed.) and Colin Gordon, Leo Marshall, John Mepham, Kate Soper (Trans.). Power/Knowledge: Selected Interviews and Other Writings 1972-1977. New York: Pantheon Books.

Foucault, Michel. [1961] 1988. Madness and Civilization: A History of Insanity in the Age of Reason. Richard Howard (Trans.). New York: Vintage Books.

Foucault, Michel. [1976] 2000. Truth and Power. In Robert Hurley and others (Trans.), James D. Faubion (Ed.). Power: Essential Works of Foucault 1954-1984 vol. III. New York: The New Press.

Foucault, Michel. [1978] 1990. The History of Sexuality Vol. I. Robert Hurley (Trans.). New York: Vintage Books.

Foucault, Michel. [1979] 2000. “Omnes et Singulatim”: Toward a Critique of Political Reason. In Hurley, Robert and others (Trans.) James D. Faubion (Ed.). Power: Essential Works of Foucault 1954-1984, vol. III. New York: The New Press.

Foucault, Michel. [1982] 2000. The Subject and Power. In Hurley, Robert and others

(Trans.) James D. Faubion (Ed.). Power: Essential Works of Foucault 1954-1984, vol. III. New York: The New Press.

Foucault, Michel. 1986. Kant on Enlightenment and Revolution. Economy and Society $15: 1$, pp. 88-96.

Foucault, Michel. 1991. Governmentality. In Graham Burchell, Colin Gordon and Peter Miller (Eds.). The Foucault Effect: Studies in Governmentality. Chicago: University of 


\section{Chicago Press.}

Foucault, Michel. 1994. Truth and juridical forms. In P. Rabinow and J. Faubion (Eds.). The Essential Works of Michel Foucault Vol.3. New York: The New Press.

Foucault, Michel. 2003. "Society Must Be Defended": Lectures at the College de France, 1975-1976. Mauro Bertani and Alessandro Fontana (Eds.). David Macey (Trans.). New York: Picador.

Foucault, Michel. 2007. Security, Territory, Population: Lectures at the College de France, 1977-1978. Michel Senellart (Ed.). Graham Burchell (Trans.). New York: Palgrave MacMillan.

Foucault, Michel. 2008. The Birth of Biopolitics: Lectures at the College de France, 19781979. Michel Senellart (Ed.). Graham Burchell (Trans.). New York: Palgrave MacMillan.

Fox, Celina. 1978. Political Caricature and the Freedom of the Press in Early NineteenthCentury England. In Tustall, Jeremy (Ed.). Newspaper History: from the Seventeenth Century to the Present Day. London: Constable, pp. 226-246.

Fraser, Nancy. 1987. What is Critical about Critical Theory: The Case of Habermas and Gender. New German Critique 35, pp. 97-131. Also re-published: 1987 in Benhabib, S. and Cornell, D. (Eds.) Feminism as Critique. Cambridge: Polity Press.

Fraser, Nancy. 1990. Rethinking the Public Sphere: A Contribution to the Critique of Actually Existing Democracy. Social Text 25/26, pp. 56-80. Also re-published: 1992 in Calhoun, Craig (Ed.) Habermas and the Public Sphere. Cambridge: MIT Press, pp. 109142.

Fraser, W. Hamish. 1981. The Coming of the Mass Market, 1850-1914. London and Basingstoke: Macmillan Press.

Fyson, Robert. 1982. The Crisis of 1842: Chartism, the Colliers' Strike and the Outbreak in the Potteries. In Epstein, James and Thompson, Dorothy (Eds.). The Chartist Experience: Studies in Working-Class Radicalism and Culture, 1830-1860. London: 
MacMillan Publishers Ltd, pp. 194-220.

Gaskell, S. Martin. 1980. Gardens for the Working Class: Victorian Practical Pleasure. Victorian Studies 23:4, pp. 479-501.

Gilmartin, Kevin. 1994. Popular Radicalism and the Public Sphere. Studies in Romanticism 33:4, pp. 549-557.

Gordon, Todd. 2006. Cops, Crime and Capitalism: The Law-and-Order Agenda in Canada. Halifax: Fernwood Publishing.

Gorz, André. 1989. Critique of Economic Reason. Gillian Handyside and Chris Turner (Trans.). London and New York: Verso.

Gosden, P.H.J.H. 1961. The Friendly Societies in England, 1815-1875. Manchester: The University Press.

Greig, Hannah. 2012. "All Together and All Distinct": Public Sociability and Social Exclusivity in London's Pleasure Gardens, ca. 1740-1800. Journal of British Studies 51:1, pp. 50-75.

Habermas, Jürgen. [1962] 1991. The Structural Transformation of the Public Sphere: An Inquiry into a Category of Bourgeois Society. Thomas Burger (Trans.). Cambridge: MIT Press.

Habermas, Jürgen. [1964] 1974. The Public Sphere: An Encyclopedia Article. New German Critique 3, pp. 49-55.

Habermas, Jürgen. [1981] 1984. The Theory of Communicative Action Volume One: Reason and the Rationalization of Society. Thomas McCarthy (Trans.). Boston: Beacon Press.

Habermas, Jürgen. [1989] 1994. The New Conservatism: Cultural Criticism and the Historians' Debate. Cambridge: Polity Press.

Habermas, Jürgen. 1981. Modernity versus Postmodernity. Seyla Ben-Habib (Trans.). New German Critique 22, pp. 3-14. 
Habermas, Jürgen. 2005. The Illusionary Leftist "No": Adopting the Constitution to Strengthen Europe's Power to Act. http://www.signandsight.com/features/163.html. Retrieved on 12.10.2012.

Halasz, Alexandra. 1997. The Market Place of Print: Pamphlets and the Public Sphere in Early Modern England. Cambridge: Cambridge University Press. Chapters 1, 2 \& 5.

Halevy, Elie. 1949. A History of the English People Vol. I. E. I. Watkin and D. A. Barker (Trans.). London: E. Benn.

Hall, Stuart and Scraton, Phil. 1981. Law, Class and Control. In Fitzgerald, Mike et $\underline{\text { al }}$ (Eds.). Crime and Society. London: Routledge \& Kegan Paul, pp. 460-97.

Hall, Stuart, Chas Critcher, Tony Jefferson, John Clarke and Brian Roberts. 1978. Policing the Crisis: Mugging, the State, and Law and Order. London: Macmillan.

Hall, Stuart. 1987. Gramsci and Us. Marxism Today, June 1987, pp. 16-21.

Hall, Stuart. 1996. The Meaning of New Times. In David Morley and Kuan-Hsing Chen (Eds.). Stuart Hall: Critical Dialogues in Cultural Studies. London: Routledge.

Hall, Stuart. 1997. The Spectacle of the Other. In Stuart Hall (Ed.). Representation: Cultural Representations and Signifying Practices. London: Sage Publications.

Hardy, Thomas. [1799]1983. Thomas Hardy's Account of the Origin of the London Corresponding Society, 1799. In Mary Thale (Ed.). Selections from the Papers of the London Corresponding Society, 1792-1799, Cambridge: Cambridge University Press.

Harring, Sydney L. 1993. Policing and Class Society: The Expansion of the Urban Police in the Late Nineteenth and Early Twentieth Centuries. In Greenberg, David F. (Ed.). Crime and Capitalism: Readings in Marxist Criminology. Philadelphia: Temple University Press, pp. 546-67.

Hart, Jennifer. 1977. Religion and Social Control in the Mid-nineteenth Century. In Donajgrodzki, A.P. (Ed.). Social Control in Nineteenth Century Britain. London: Croom Helm Ltd, pp. 108-137.

Harvey, David. 1990. The Condition of Postmodernity: An Enquiry into the Origins of 
Cultural Change. Cambridge and Oxford: Blackwell.

Harvey, David. 2004. The New Imperialism: Accumulation by Dispossession. $\underline{\text { Socialist }}$ Register 2004, pp. 64-87.

Harvey, David. 2006. The Political Economy of Public Space. In Low, Setha and Smith,

Neil (Eds.). The Politics of Public Space. New York and London: Routledge, pp. 17-34.

Harvey, David. 2008. The Right to the City. New Left Review 53, pp. 23-40.

Harvey, David. 2012. Rebel Cities: From the Right to the City to the Urban Revolution. New York and London: Verso.

Hay, Douglas. 1980. Crime and Justice in Eighteenth- and Nineteenth-Century England. Crime and Justice 2, pp. 45-84.

Haywood, Ian. 1984. The Revolution in Popular Literature: Print, Politics and the People, 1790-1860. Cambridge: Cambridge University Press.

Hibbert, Christopher, Ben Weinreb, John Keay, Julia Keay (Eds.). [1983]2008. The London Encyclopedia, $3^{\text {rd }}$ Edition. London: Macmillan.

Higgs, Henry (ed.). 1926. Palgrave's Dictionary of Political Economy vol. III. London: Macmillan and Co.

Hindess, Barry. 1977. Philosophy and Methodology in the Social Sciences. Sussex: The Harvester Press.

Hirst, Paul. 1975. Marx and Engels on Law, Crime and Morality. In Taylor, Walton and Young (Eds.) Critical Criminology. London: Routledge.

Hobbes, Thomas. [1651] 1985. Leviathan. London: Penguin Books.

Hobsbawn, Eric J. 1962. The Age of Revolution: 1789-1848. New York: New American Library.

Hobsbawn, Eric J. 1974. Labor History and Ideology. Journal of Social History 7:4, pp. $371-381$.

Hohendahl, Peter Uwe. 1974. Jürgen Habermas: "The Public Sphere" (1964). New German 
Critique 3, pp. 45-48.

Hohendahl, Peter Uwe. 1979. Critical Theory, Public Sphere and Culture: Jürgen Habermas and His Critics. New German Critique 16, pp. 89-118.

Hollis, Patricia. 1970. The Pauper Press: A Study in Working-Class Radicalism of the 1830s. London: Oxford University Press.

Horkheimer, Max and Adorno Theodor W. 2002. Dialectic of Enlightenment: Philosophical Fragments. Edmund Jephcott (Trans.). Gunzelin Schmid Noerr (Ed.). Stanford: Stanford University Press.

Hunt, Alan. 1980. Introduction: Taking Democracy Seriously. In Alan Hunt (Ed.). Marxism and Democracy. London: Lawrence and Wishart.

Hunt, Alan. 1995. Moralizing Luxury: The Discourses of the Governance of Consumption. Journal of Historical Sociology 8:4, pp. 352-374.

Hunt, Alan. 1996. The Governance of Consumption: Sumptuary Laws and Shifting Forms of Regulation. Economy and Society 25:3, pp. 410-427.

Hunt, Alan. 1996. Governance of the Consuming Passions: A History of Sumptuary Law. New York: St Martin's Press. Chapters 11-15.

Hunt, Alan. 1996. Governing the City: Liberalism and Early Modern Modes of Governance. In Barry, Andrew, Osborne, Thomas and Rose, Nicholas (Eds.). Foucault and Political Reason: Liberalism, Neo-Liberalism and Rationalities of Government. Chicago: University of Chicago Press, pp. 167-188.

Hunt, Alan. 1999. Governing Morals: A Social History of Moral Regulation. Cambridge: Cambridge University Press.

Hunt, Alan. 2003. Risk and Moralization in Everyday Life. In Richard V. Ericson and Aaron Doyle (Eds.). Risk and Morality. Toronto: University of Toronto Press, pp. 165193.

Hunt, Alan. 2006. Police and the Regulation of Traffic: Policing as a Civilizing Process? In Dubber, Markus D. and Valverde, Mariana (Eds.). The New Police Science: The 
Police Power in Domestic and International Governance. Stanford: Stanford University Press, pp. 168-184.

Hunt, Alan and Trevor Purvis. 1993. Discourse, Ideology, Discourse, Ideology, Discourse, Ideology ... The British Journal of Sociology 44:3.

Hurd, Madeleine. 2000. Class, Masculinity, Manners, and Mores: Public Space and Public Sphere in Nineteenth-Century Europe. Social Science History 24:1, pp. 75-110.

Işın, Engin. 1992. Cities without Citizens: The Modernity of the City as a Corporation. Montreal/New York: Black Rose Books.

Jacobs, Edward. 2008. The Politicization of Everyday Life in Cleave's Weekly Police Gazette (1834-1836). Victorian Periodicals Review 41:3, pp. 225-247.

James, Louis. 1963. Fiction for the Working Man 1830-1850: A Study of the Literature Produced for the Working Classes in Early Victorian Urban England. London: Oxford University Press. Chapters 1, 2, 3 and 9.

Jameson, Fredric. 1988. On Negt and Kluge. October 46, pp. 151-177.

Johnson, Roy. 1975. The Proletarian Novel. Literature and History 2:2, pp. 84-95.

Jones, Gareth S. 1982. The Language of Chartism. In Epstein, James and Thompson, Dorothy (Eds.). The Chartist Experience: Studies in Working-Class Radicalism and Culture, 1830-1860. London: MacMillan Publishers Ltd, pp. 3-58.

Jones, D.J.V. and F.R. Hirst S. 1983. The New Police, Crime and People in England and Wales, 1829-1888. Transactions of the Royal Historical Society, Fifth Series vol. 33, pp. 151-168.

Jones, Trevor and Tim Newburn. 2002. The Transformation of Policing? Understanding Current Trends in Policing Systems. British Journal of Criminology 42, pp. 129-146.

Kant, Immanuel. [1784] 2007. Was ist Aufklärung? In Foucault, Michel, The Politics of Truth Sylvère Lotringer (Ed.). Los Angeles: Semiotext(e), pp. 29-39.

Keen, Paul. 2007. When is a Public Sphere not a Public Sphere?: Thoughts from 1795- 
1796. In Benchimol, Alex and Malley, Willy (Eds.). Spheres of Influence: Intellectual and Cultural Publics from Shakespeare to Habermas. Oxford: Peter Lang, pp. 151-174. Kipfer, Stefan. 2002. Urbanization, Everyday Life and the Survival of Capitalism: Lefebvre, Gramsci and the Problematic of Hegemony. Capitalism, Nature, Socialism $13: 2$.

Knemeyer, Franz-Ludwig. 1980. Polizei. Economy and Society 9:2, 172-196.

Knödler-Bunte, Eberhard; Lennox, Sara and Lennox, Frank. 1975. The Proletarian Public Sphere and Political Organization: An Analysis of Oskar Negt and Alexander Kluge's Public Sphere and Experience. New German Critique 4, pp. 51-75.

Koivisto, Juha and Esa Valiverronen. 1996. The Resurgence of the Critical Theories of Public Sphere. Journal of Communication Inquiry 20:2, pp. 18-36.

Krause, Monika. 2006. The Production of Counter-Publics and the Counter-Publics of Production: An Interview with Oskar Negt. European Journal of Social Theory 9:1, pp. $119-128$.

Krishnamurthy, Aruna. 2009. Coffeehouse vs. Alehouse: Notes on the Making of the Eighteenth-Century Working-Class Intellectual. In Krishnamurthy, Aruna (Ed.). The Working-Class Intellectual in Eighteenth- and Nineteenth-Century Britain. Surrey: Ashgate Publishing Company, pp. 85-108.

Lambert, Richard S. 1938. The Universal Provider: A Study of William Whiteley and the Rise of the London Department Store. London: George G. Harrap \& Co. Ltd.

Laska, Peter. 1974. A Note on Habermas and Labour Theory of Value. New German Critique 3, pp. 154-162.

Latour, Bruno. 1983. Give me a Laboratory and I will Raise the World. In $\underline{\text { Science }}$ Observed: Perspectives on the Social Study of Science. Karin D. Knorr-Cetina and Michael Mulkay (Eds.). London: Sage Publications, pp. 140-170.

Latour, Bruno. 1988. The Pasteurization of France. Cambridge, Mass: Harvard University Press. 
Latour, Bruno. 1993. We Have Never Been Modern. Cambridge: Harvard University Press.

Laurier, Eric and Philo, Chris. 2007. 'A Parcel of Muddling Muckworms': Revisiting Habermas and the English Coffee-Houses. Social and Cultural Geography 8:2, pp. 259281.

Lee, William Lauriston Melville. [1865] 1971. A History of Police in England. Montclair, N. J., Patterson Smith.

Lefebvre, Henri. [1974] 2007. The Production of Space. Donald Nicholson-Smith (Trans.). Oxford: Blackwell.

Lemke, Thomas. 2011. Critique and Experience in Foucault. Theory, Culture and Society 28:4, pp. 26-48.

Lentzos, Filippa and Rose, Nikolas. 2009. Governing Insecurity: Contingency Planning, Protection, Resilience. Economy and Society 38:2, pp. 230-254.

Linebaugh, Peter. 2003. The London Hanged: Crime and Civil Society in the Eighteenth Century, London and New York: Verso.

Linebaugh, Peter. 2014. Stop, Thief! The Commons, Enclosures, and Resistance, PM Press.

Linklater, Andrew. 2007. Public Spheres and Civilizing Processes. Theory, Culture and Society 24:4, pp. 31-37.

Lippmann, W. [1925] 1993. The Phantom Public. Transactions Publications.

Loader, Ian. 1997. Policing and the Social: Questions of Symbolic Power. British Journal of Sociology 48:1, pp. 1-18.

Loader, Ian and Walker, Neil. 2001. Policing as a Public Good: Reconstituting the Connections between Policing and the State. Theoretical Criminology 5:9.

Loader, Ian and Mulcahy, Aogan. 2003. Policing and the Condition of England: Memory, Politics and Culture. Oxford: Oxford University Press.

Locke, John. [1689] 1996. An Essay Concerning Human Understanding. Winkler, Kenneth P. (Ed.). Indianapolis and Cambridge: Hackett Publishing Company, Inc. 
Locke, John. 2003. Two Treatise of Government. Peter Laslett (Ed.). Cambridge: Cambridge University Press.

LoPatin-Lummis, Nancy. 2007. The 1832 Reform Act Debate: Should the Suffrage Be Based on Property or Taxpaying? Journal of British Studies 46:2, pp. 320-345.

Lukács, George. [1923] 1971. History and Class Consciousness: Studies in Marxist Dialectics. Rodney Livingstone (Trans.). Massachusetts: The MIT Press.

Luxemburg, Rosa. [1913]1951. The Accumulation of Capital. Agnes Schwarzschild (Trans.). London: Routledge and Kegan Paul Lim.

Lyman, J. L. 1964. The Metropolitan Police Act of 1829: An Analysis of Certain Events Influencing the Passage and Character of the Metropolitan Police Act in England. Journal of Criminal Law and Criminology 55, pp. 141-154.

Magarey, Susan. 1978. The Invention of Juvenile Delinquency in Early NineteenthCentury England. Labour History 34, pp. 11-27.

Mah, Harold. 2000. Phantasies of the Public Sphere: Rethinking the Habermas of Historians. Journal of Modern History 73, pp. 153-182.

Malchow, H. L. 1973. Victorian Pressure Groups: Directions for Research. Albion: A Quarterly Journal Concerned with British Studies 5:2, pp. 107-115.

Malchow, H. L. 1985. Public Gardens and Social Action in Late Victorian London. Victorian Studies 29:1, pp. 97-124.

Marx, Karl. 1844. Critique of Hegel's Philosophy of Right.

Marx, Karl. [1867] 1990. Capital: A Critique of Political Economy vol. I. Ben Fowles (Trans.). London: Penguin Books.

Marx, Karl and Frederick Engels. [1845] 1968. The German Ideology. S. Ryazanskaya (Trans. and Ed.). Moscow: Progress Publishers.

Marx, Karl and Friedrich Engels. [1848] 1977. Manifesto of the Communist Party. Samuel Moore (Trans.). Moscow: Progress Publishers. 
Marx, Karl. The Class Struggle in France, 1848 to 1850.

Marx, Karl and Frederick Engels. 1962. Marx and Engels on Britain. Moscow: Progress Publishers.

McLaughlin, Eugene. 2007. The New Policing. London: Sage.

McMullan, John L. 1995. The Political Economy of Thief-Taking. Crime, Law and Social Change 23:2, pp. 121-146.

McMullan, John L. 1996. The New Improved Monied Police: Reform, Crime Control, and the Commodification of Policing in London. British Journal of Criminology 36:1, pp. 85-108.

McMullan, John L. 1998. Policing Reform and Moral Discourse: The Genesis of a Modern Institution. Policing: An International Journal of Police Strategies and Management 21:1, pp. 137-158.

McMullan, John L. 1998. Social Surveillance and the Rise of the 'Police Machine.' Theoretical Criminology 2:1, pp. 93-117.

Miller, Wilbur R. 1977. Never on Sunday: Moralistic Reformers and the Police in London and New York City, 1830-1870. In Bayley, David H. (Ed.). Police and Society. London: Sage Publications, pp. 127-148.

Mitchell, Dean. 1992. A Genealogy of the Government of Poverty. Economy and Society 21:2, pp. 215-251.

Mountjoy, Peter Roger. 1978. The Working-Class Press and Working-Class Conservatism. In Tustall, Jeremy (Ed.). Newspaper History: from the Seventeenth Century to the Present Day. London: Constable, pp. 265-280.

Murphy, Andrew. 2007. Publicizing Shakespeare: The Canonical Text and the Public Sphere. In Benchimol, Alex and Malley, Willy (Eds.). Spheres of Influence: Intellectual and Cultural Publics from Shakespeare to Habermas. Oxford: Peter Lang, pp. 85-102.

Murphy, Elaine. 2003. The New Poor Law Guardians and the Administration of Insanity in East London, 1834-1844. Bulletin of the History of Medicine 77, pp. 45-74. 
Navickas, Katrina. 2010. "That sash will hang you”: Political Clothing and Adornment in England, 1780-1840. Journal of British Studies 49:3, pp. 540-565.

Neeson, J. M. 1993. Commoners: Common Right, Enclosure and Social Change in England 1700-1820. Cambridge University Press.

Negt, Oskar and Kluge, Alexander. [1972] 1993. Public Sphere and Experience: Towards an Analysis of the Bourgeois and Proletarian Public Sphere. Peter Labanyi, Jamie Owen Daniel, and Assenka Oksiloff (Trans.). Minneapolis and London: University of Minnesota Press.

Neocleous, Mark. 1995. From Civil Society to the Social. The British Journal of Sociology 46:3, pp. 395-408.

Neocleous, Mark. 2000. Social Police and the Mechanisms of Prevention: Patrick Colquhoun and the Condition of Poverty. British Journal of Criminology 40, pp. 710726.

Neocleous, Mark. 2000. The Fabrication of Social Order: A Critical Theory of Police Power. London: Pluto Press.

Neocleous, Mark. 2002. Privacy, Secrecy, Idiocy. Social Research 69:1, pp. 85-110.

Neocleous, Mark. 2006. Theoretical Foundations of the "New Police Science." In Dubber, Markus D. and Valverde, Mariana (Eds.). The New Police Science: The Police Power in Domestic and International Governance. Stanford: Stanford University Press, pp. 1741 .

Neocleous, Mark. 2007. Security, Commodity, Fetishism. Critique 35:3, pp. 339-355.

Neocleous, Mark. 2008. Critique of Security. Montreal \& Kingston: McGill-Queen's University Press.

Neocleous, Mark. 2014. War Power, Police Power. Edinburgh: Edinburgh University Press. Nielsen, Henrik Kaare. 2008. The Aestheticization of the Public Sphere and Its Consequences for Democratic Political Culture.

http://socioaesthetics.ku.dk/uploads/HKNsocioaesth.pdf (accessed on March 20, 2017). 
Ogborn, Miles. 1993. Ordering the City: Surveillance, Public Space and the Reform of Urban Policing in England. Political Geography 12:6, pp. 505-521.

O’Malley, Pat and D. Palmer. 1996. Post-Keynesian Policing. Economy and Society 25:2, 137-155.

Osborne, Thomas. 1996. Security and Vitality: Drains, Liberalism and Power in the Nineteenth Century. In Barry, Andrew, Osborne, Thomas and Rose, Nicholas (Eds.). Foucault and Political Reason: Liberalism, Neo-Liberalism and Rationalities of Government. Chicago: University of Chicago Press, pp. 99-122.

Palmer, Stanley H. 1988. Police and Protest in England and Ireland, 1780-1850. New York: Cambridge University Press.

Pasdermadjian, Hrant. [1954]1976. The Department Store: Its Origins, Evolution and Economics. London: Arno Press.

Pashukanis, Evgeny B. 1978. Law and Marxism: A General Theory. Barbara Einhorn (Trans.). London: Ink Links.

Pasquino, Pasquale. 1986. Michel Foucault (1926-84): The Will to Knowledge. Chloe Chard (Trans.). Economy and Society 15:1, pp. 97-109.

Pasquino, Pasquale. 1991. Theatrum Politicum: The Genealogy of Capital - Police and the State of Prosperity. In Burchell, Graham, Gordon, Colin and Miller, Peter (Eds.). The Foucault Effect: Studies in Governmentality. Chicago: University of Chicago Press, pp. $105-118$.

Pasquino, Pasquale. 1991. Criminology: The Birth of a Special Knowledge. In Burchell, Graham, Gordon, Colin and Miller, Peter (Eds.). The Foucault Effect: Studies in Governmentality. Chicago: University of Chicago Press, pp. 235-250.

Peddie, Ian. 2009. Playing at Poverty: The Music Hall and the Staging of the Working Class. In Krishnamurthy, Aruna (Ed.). The Working-Class Intellectual in Eighteenthand Nineteenth-Century Britain. Surrey: Ashgate Publishing Company, pp. 235-254.

Pennington, W. 1769. Reflections on the Various Advantages Resulting from the Draining, 
Inclosing and Allotting of Large Commons and Common Fields. London.

Petty, Sir William. 1927. The Petty Papers: Some Unpublished Writings (vols. I-II). London: Constable.

Philips, David and Robert D. Storch. 1999. Policing Provincial England, 1829-1856: The Politics of Reform. London: Leicester University Press.

Plotz, John. 2000. Crowd Power: Chartism, Carlyle, and the Victorian Public Sphere. Representations 70 , pp. 87-114.

Postles, Dave. 2004. The Market Place as Space in Early Modern England. Social History 29:1, pp. 41-58.

Prince, Kathryn. 2009. Shakespeare in the Early Working-Class Press. In Krishnamurthy, Aruna (Ed.). The Working-Class Intellectual in Eighteenth- and Nineteenth-Century Britain. Surrey: Ashgate Publishing Company, pp. 129-142.

Procacci, Giovanna. 1991. Social Economy and the Government of Poverty. In Burchell, Graham, Gordon, Colin and Miller, Peter (Eds.). The Foucault Effect: Studies in Governmentality. Chicago: University of Chicago Press, pp. 151-168.

Purvis, Terevor \& Alan Hunt. 1993. Discourse, Ideology, Discourse, Ideology, Discourse, Ideology... British Journal of Sociology 44:3, 473-499.

Radzinowicz, Leon. 1948. A History of English Criminal Law and Its Administration from 1750. London: Stevens.

Raeff, Marc. 1975. The Well-Ordered Police State and the Development of Modernity in Seventeenth- and Eighteenth-Century Europe: An Attempt at a Comparative Approach. The American Historical Review 80:5, pp. 1221-1243.

Ravenhill-Johnson, Annie. 2013. The Art and Ideology of the Trade Union Emblem, 18501925. Paula James (Ed.). London: Anthem Press.

Raymond, Joad. 2007. Perfect Speech: The Public Sphere and Communication in Seventeenth-Century England. In Benchimol, Alex and Malley, Willy (Eds.). Spheres of Influence: Intellectual and Cultural Publics from Shakespeare to Habermas. Oxford: 
Peter Lang, pp. 43-69.

Reid, A. 1982. Interpreting the Festival Calendar: Wakes and Fairs as Carnivals. In Storch Robert D. (Ed.) Popular Culture and Custom in Nineteenth-Century England. London: Croom Helm Ltd, pp. 125-153.

Reiner, Robert. 1978. The Police in the Class Structure. British Journal of Law and Society 5:2, pp. 166-184.

Reiner, Robert. 2000. The Politics of the Police. New York: Oxford University Press.

Reiner, Robert. 2010. New Theories of Policing: A Social Democratic Critique. In David Downes, Dick Hobbs, and Tim Newburn (Eds.). The Eternal Recurrence of Crime and Control: Essays in Honour of Paul Rock. Oxford: Oxford University Press, pp. 141-182.

Reiner, Robert. 2011. Policing, Popular Culture and Political Economy: Towards a Social Democratic Criminology. London: Ashgate Publishing.

Reith, Charles. 1938. The Police Idea, Its History and Evolution in England in the Eighteenth Century and After. London, Toronto: Oxford University Press.

Reynolds, Elaine. 1998. Before the Bobbies: The Night Watch and Police Reform in Metropolitan London, 1720-1830. Stanford: Stanford University Press.

Rigakos, George S. and Hadden Richard W. 2001. Crime, Capitalism and the 'Risk Society': Towards the Same Olde Modernity. Theoretical Criminology 5:1, pp. 61-84.

Rigakos, George S. 2002. The New Parapolice: Risk Markets and Commodified Social Control. Toronto: University of Toronto Press, Chapters $1 \& 3$.

Rigakos, George S. 2016. Security/Capital: A General Theory of Pacification. Edinburgh: Edinburgh University Press.

Rigakos, George S. and Papanicolaou, Georgios. 2003. The Political Economy of Greek Policing: Between Neo-Liberalism and The Sovereign State. Policing and Society 13:3, pp. 271-304.

Rigakos, G. S., McMullan, J. et al (Eds.). 2009. A General Police System: Political 
Economy and Security in the Age of Enlightenment. Ottawa: Red Quill Books.

Robbins, Bruce (Ed.). 1993. The Phantom Public Sphere. Minneapolis and London: University of Minnesota Press.

Robinson Cyril D. and Scaglion, Richard. 1987. The Origin and Evolution of the Police Function in Society: Notes toward a Theory. Law and Society Review 21:1, pp. 109153.

Roberts, M.J.D. 1988. Public and Private in Early Nineteenth-Century London: The Vagrant Act of 1822 and Its Enforcement. Social History 13:3, pp. 273-294.

Roberts, M.J.D. 2004. Making English Morals: Voluntary Association and Moral Reform in England, 1787-1886. Cambridge: Cambridge University Press.

Rogers, Nicholas. 1991. Policing the Poor in Eighteenth-Century London: The Vagrancy Laws and Their Administration. Social History/Histoire Sociale 24:47, pp. 127-147.

Rose, Nikolas and Peter Miller. 1992. Political Power beyond the State: Problematics of Government. British Journal of Sociology 43:2, 173-205.

Rousseau, Jean-Jacques. [1755]1997. Discourse on Political Economy. In The Social Contract and Other Political Writings. Victor Gourevitch (trans. and ed.). Cambridge: Cambridge University Press.

Rude, George. 1973. Protest and Punishment in Nineteenth-Century Britain. Albion: A Quarterly Journal Concerned with British Studies 5:1, pp. 1-23.

Rule, John. 1982. Methodism, Popular Beliefs and Village Culture in Cornwall, 1800-1850. In Storch Robert D. (Ed.). Popular Culture and Custom in Nineteenth-Century England. London: Croom Helm Ltd, pp. 48-70.

Santos, Boaventura de Sousa. 2004. Toward a New Legal Common Sense: Law, Globalization, and Emancipation. Cambridge: Cambridge University Press.

Schivelbusch, Wolfgang. [1977]1986. The Railway Journey: The Industrialization of Time and Space in the 19th Century. Berkeley and Los Angeles: University of California Press. 
Schmitt, Carl. 1985. Political Theology: four chapters on the concept of sovereignty. Chicago: University of Chicago Press.

Schwab, Ulrich. 1987. The Poetry of the Chartist Movement: A Literary and Historical Study. Dordrecht: Kluwer Academic Publishers.

Sennett, Richard. 1992. The Fall of Public Man. New York and London: W.W. Norton \& Company.

Sennett, Richard. 1998. The Corrosion of Character: The Personal Consequences of Work in the New Capitalism. New York: W. W. Norton\&Company.

Sewell, William H. 1990. How Classes are Made: Critical Reflections on E.P. Thompson's Theory of Working-class Formation. In Kaye, Harvey J. and McClelland, Keith (Eds.). E.P. Thompson: Critical Perspectives. Philadelphia: Temple University Press, pp. 5078.

Shearing, Clifford. 2007. Policing Our Future. In A. Henry and D. Smith (Eds.). Transformation of Policing. Aldershot: Ashgate.

Silver, Allan. 1967. The Demand for Order in Civil Society: A Review of Some Themes in the History of Urban Crime, Police and Riot. In David Bordua (Ed.). The Police: $\underline{\text { Six }}$ Sociological Essays. John Wiley: New York, pp.1-24.

Sindall, R. 1987. The London Garotting Panics of 1856 and 1862. Social History 12:3, pp. 351-359.

Small, Albion. 2001. The Cameralists: The Pioneers of German Polity. Kitchener: Batoche Books.

Smith, Adam. [1760s] 1982. Lectures on Jurisprudence. Meek, R.L.; Raphael, D.D. and Stein, P.G. (Eds.). Indianapolis: Liberty Classics.

Smith, Adam. 1896. Lectures on Justice, Police, Revenue and Arms. London: Kessinger Press.

Spitzer, Steven. 1980. The Political Economy of Policing. In David F. Greenberg (Ed.). Crime and Capitalism: Readings in Marxist Criminology. Mayfield Publishing Co.: Palo 
Alto, pp. 568-594. Re-published by Philadelphia: Temple University Press in 1993.

Spitzer, Steven. 1987. Security and Control in Capitalist Societies: The Fetishism of Security and the Secret Thereof. In J. Lowman and R. J. Menzies and T. S. Palys (Eds.). Transcarceration: Essays in the Sociology of Social Control. Aldershot: Gower, pp. 4358.

Stead, Philip John. 1977. The New Police. In Bayley, David H. (Ed.). Police and Society. London: Sage Publications, pp. 73-84.

Stevenson, John. 1977. Social Control and the Prevention of Riots in England, 1789-1829.

In Donajgrodzki, A.P. (Ed.). Social Control in Nineteenth Century Britain. London: Croom Helm Ltd, pp. 27-50.

Storch, Robert D. 1976. The Policeman as Domestic Missionary: Urban Discipline and Popular Culture in Northern England, 1850-1880. Journal of Social History 9:4, 481509.

Storch, Robert D. 1977. Police Control of Street Prostitution in Victorian London: A Study in the Contexts of Police Action. In Bayley, David H. (Ed.). Police and Society. London: Sage Publications, pp. 49-72.

Storch, Robert D. 1977. The Problem of Working-Class Leisure. Some Roots of MiddleClass Moral Reform in the Industrial North: 1825-1850. In Donajgrodzki, A.P. (Ed.). Social Control in Nineteenth Century Britain. London: Croom Helm Ltd, pp. 138-162.

Storch, Robert D. 1981. The Plague of the Blue Locust: Police Reform and Popular Resistance in Northern England, 1840-1857. In Fitzgerald, Mike, McLennan, Gregor and Pawson, Jennie (Eds.). Crime and Society: Readings in History and Theory. London: Routledge, pp. 61-90.

Storch, Robert D. 1982. 'Please to Remember the Fifth of November': Conflict, Solidarity and Public Order in Southern England, 1815-1900. In Storch Robert D. (Ed.). Popular Culture and Custom in Nineteenth-Century England. London: Croom Helm Ltd, pp. 7199. 
Storch, Robert D. 1982. Introduction: Persistence and Change in Nineteenth-Century Popular Culture. In Storch Robert D. (Ed.). Popular Culture and Custom in NineteenthCentury England. London: Croom Helm Ltd, pp. 1-19.

Taylor, David. 1997. The New Police in the Nineteenth-Century England: Crime, Conflict and Control. New York: Manchester University Press.

Thompson, Dorothy. 1984. The Chartists: Popular Politics in the Industrial Revolution. London: Pantheon Books.

Thompson, E.P. 1957. Socialist Humanism. The New Reasoner 1 Summer: 105-143.

Thompson, E.P. [1963] 1991. The Making of the English Working Class. London: Penguin Books.

Thompson, E.P. 1967. Time, Work-Discipline, and Industrial Capitalism. Past and Present 38:1, pp. 56-97.

Thompson, E.P. 1971. The Moral Economy of the English Crows in the Eighteenth Century. Past \& Present 50, pp. 76-136.

Thompson, E.P. 1975. Whigs and Hunters: The Origin of the Black Act. New York: Pantheon Books.

Thompson, E.P. 1978. Eighteenth-century English Society: Class Struggle without Class? Social History 3:2, pp. 133-165.

Thompson, F.M.L. 1981. Social Control in Victorian Britain. The Economic History Review 34:2, pp. 189-208.

Thompson, John B. 1983. Rationality and Social Rationalisation: An Assessment of Habermas's Theory of Communicative Action. Sociology 17:2, pp. 278-294.

Valverde, Mariana. 2003. Police Science, British Style: Pub Licensing and Knowledges of Urban Disorder. Economy and Society 32:2, pp. 234-252.

Valverde, Mariana. 2003. Law's Dream of a Common Knowledge. Princeton and Oxford: Princeton University Press. 
Valverde, Mariana. 2007. Genealogies of European States: Foucauldian Reflections. Economy and Society 36:1, pp. 159-178.

Valverde, Mariana. 2008. Questions of Security. Presented at the Dedication of the Richard Ericson Seminar Room, Centre for Criminology \& Sociolegal Studies.

Valverde, Mariana. 2010. The Force of Law. Toronto: Groundwood Books.

Verstraeten, Hans. 1996. The Media and the Transformation of the Public Sphere: A Contribution for a Critical Political Economy of the Public Sphere. European Journal of Communication 11:3, pp. 347-370.

Vincent, David. 1982. The Decline of the Oral Tradition in Popular Culture. In Storch Robert D. (Ed.). Popular Culture and Custom in Nineteenth-Century England. London: Croom Helm Ltd, pp. 20-47.

Voskuil, Lynn M. 2002. Feeling Public: Sensation Theatre, Commodity Culture, and the Victorian Public Sphere. Victorian Studies 44:2, pp. 245-274.

Walton, John K. 1981. The Demand for Working-Class Seaside Holidays in Victorian England. Economic History Review 34:2, pp. 249-265.

Walton, John K. and Poole, Robert. 1982. The Lancashire Wakes in the Nineteenth Century. In Storch Robert D. (Ed.). Popular Culture and Custom in Nineteenth-Century England. London: Croom Helm Ltd, pp. 100-124.

Warner, Michael. 2002. Publics and Counterpublics. Public Culture 14:1, pp. 49-90.

Warner, Michael. 2005. Publics and Counterpublics. New York: Zone Books.

Weintraub, Jeff. 1997. The Theory and Politics of the Public/Private Distinction. In Weintraub, Jeff and Kumar, Krishan (Eds.). Public and Private in Thought and Practice: Perspectives on a Grand Dichotomy. Chicago and London: The University of Chicago Press, pp. 1-43.

Williams, Raymond. 1978. The Press and Popular Culture: A Historical Perspective. In Tustall, Jeremy (Ed.). Newspaper History: from the Seventeenth Century to the Present Day. London: Constable, pp. 41-50. 
Wood, Ellen M. 2002. The Origin of Capitalism: A Longer View. London: Verso.

Yeo, Eileen. 1982. Some Practices and Problems of Chartist Democracy. In Epstein, James and Thompson, Dorothy (Eds.). The Chartist Experience: Studies in Working-Class Radicalism and Culture, 1830-1860. London: MacMillan Publishers Ltd, pp. 345-380. 